\title{
Microbanded Manganese Formations: Protoliths in the Franciscan Complex, California
}

U.S. GEOLOGICAL SURVEY PROFESSIONAL PAPER 1502

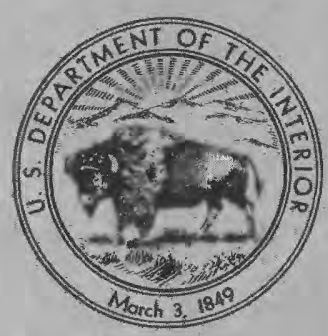




\section{AVAILABILITY OF BOOKS AND MAPS OF THE U.S. GEOLOGICAL SURVE}

Instructions on ordering publications of the U.S. Geological Survey, along with prices of the last offerings, are given in the rent-year issues of the monthly catalog "New Publications of the U.S. Geological Survey." Prices of available U.S. Geological s vey publications released prior to the current year are listed in the most recent annual "Price and Availability List." Publicat that are listed in various U.S. Geological Survey catalogs (see back inside cover) but not listed in the most recent annual "Price Availability List" are no longer available.

Prices of reports released to the open files are given in the listing "U.S. Geological Survey Open-File Reports," updated mor ly, which is for sale in microfiche from the U.S. Geological Survey, Books and Open-File Reports Section, Federal Center, I 25425, Denver, CO 80225. Reports released through the NTIS may be obtained by writing to the National Technical Informa Service, U.S. Department of Commerce, Springfield, VA 22161; please include NTIS report number with inquiry.

Order U.S. Geological Survey publications by mail or over the counter from the offices given below.

\section{BY MAIL}

\section{Books}

Professional Papers, Bulletins, Water-Supply Papers, Techniques of Water-Resources Investigations, Circulars, publications of general interest (such as leaflets, pamphlets, booklets), single copies of Earthquakes \& Volcanoes, Preliminary Determination of Epicenters, and some miscellaneous reports, including some of the foregoing series that have gone out of print at the Superintendent of Documents, are obtainable by mail from

\section{U.S. Geological Survey, Books and Open-File Reports Federal Center, Box 25425 Denver, CO 80225}

Subscriptions to periodicals (Earthquakes \& Volcanoes and Preliminary Determination of Epicenters) can be obtained ONLY from the

\section{Superintendent of Documents Government Printing Office Washington, D.C. 20402}

(Check or money order must be payable to Superintendent of Documents.)

\section{Maps}

For maps, address mail orders to

$$
\begin{gathered}
\text { U.S. Geological Survey, Map Distribution } \\
\text { Federal Center, Box } 25286 \\
\text { Denver, CO } 80225
\end{gathered}
$$

Residents of Alaska may order maps from

$$
\begin{gathered}
\text { Alaska Distribution Section, U.S. Geological Survey, } \\
\text { New Federal Building - Box } 12 \\
101 \text { Twelfth Ave., Fairbanks, AK } 99701
\end{gathered}
$$

\section{OVER THE COUNTER}

\section{Books}

Books of the U.S. Geological Survey are available over counter at the following Geological Survey Public Inquiries Offices of which are authorized agents of the Superintendent of Document

- WASHINGTON, D.C.--Main Interior Bldg., 2600 corridor, 18 th and C Sts., NW.

- DENVER, Colorado--Federal Bldg., Rm. 169, 1961 Stout S

- LOS ANGELES, California--Federal Bldg., Rm. 7638, 300 Los Angeles St.

- MENLO PARK, California--Bldg. 3 (Stop 533), Rm. 3128 345 Middlefield Rd.

- RESTON, Virginia--503 National Center, Rm. 1C402, 1220 Sunrise Valley Dr.

- SALT LAKE CITY, Utah--Federal Bldg., Rm. 8105, 125 South State St.

- SAN FRANCISCO, California--Customhouse, Rm. 504, 5 Battery St.

- SPOKANE, Washington-U.S. Courthouse, Rm. 678, Wes 920 Riverside Ave.

- ANCHORAGE, Alaska--Rm. 101, 4230 University Dr.

- ANCHORAGE, Alaska--Federal Bldg, Rm. E-146, 701 C S

\section{Maps}

Maps may be purchased over the counter at the U.S. Geol cal Survey offices where books are sold (all addresses in above list) at the following Geological Survey offices:

- ROLLA, Missouri-1400 Independence Rd.

- DENVER, Colorado--Map Distribution, Bldg. 810, Federal Center

- FAIRBANKS, Alaska--New Federal Bldg., 101 Twelfth Av 


\title{
Microbanded Manganese Formations: Protoliths in the Franciscan Complex, California
}

\author{
By J. STEPHEN HUEBNER and MARTA J.K. FLOHR
}

U.S. GEOLOGIGAL SURVEY PROFESSIONAL PAPER 1502

Petrographic features, chemistry, and origin of protoliths, which included gel-like materials, of the manganese-rich carbonate, silicates, and oxides that form lenses in cherts of the Franciscan Complex

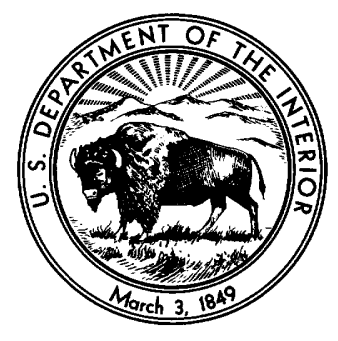




\section{TABLES}

TABLE 1. Known and hypothetical manganese minerals and common analogues discussed in text

2. Standards used for electron microprobe analysis of samples from the Buckeye deposit, California Coast Ranges..................

3. Constituents of graywackes from the Buckeye deposit, California Coast Ranges.

4. Characterization of metasandstones, metacarbonates, and metavolcanic rocks from the Buckeye deposit, California Coast Ranges, by X-ray powder diffractometry

5. Compositions of minerals from nonsiliceous host rock, in weight percent, from the Buckeye deposit, California Coast Ranges, determined by electron microprobe analysis

6. Chemistry and mineralogy of selected protoliths from the Buckeye deposit, California Coast Ranges.....

7. Characterization of siliceous samples from the Buckeye deposit, California Coast Ranges, by X-ray powder diffractometry....

8. Compositions of gel-like materials, in weight percent, from the Buckeye deposit, California Coast Ranges, determined by electron microprobe analysis

9. Compositions of silicates from the Buckeye deposit, California Coast Ranges, determined by electron microprobe analysis ....

10. Compositions of vein minerals from the Buckeye deposit, California Coast Ranges, determined by electron microprobe analysis

11. Compositions of rhodochrosite from the Buckeye deposit, California Coast Ranges, determined by electron microprobe analysis

12. Compositions of the oxides braunite and hausmannite from the Buckeye deposit, California Coast Ranges, determined by electron microprobe analysis

13. Comparison of the Buckeye deposit, California, and some modern deep marine Mn-rich deposits. 


\title{
MICROBANDED MANGANESE FORMATIONS: PROTOLITHS IN THE FRANCISCAN COMPLEX, CALIFORNIA
}

\author{
By J. Stephen Huebner and Marta J.K. Flohr
}

\begin{abstract}
The Buckeye manganese deposit, $93 \mathrm{~km}$ southeast of San Francisco in the California Coast Ranges, preserves a geologic history that provides clues to the origin of numerous lenses of manganese carbonate, oxides, and silicates that occur with interbedded radiolarian chert and metashale of the Franciscan Complex. Compositionally and mineralogically laminated $\mathrm{Mn}$-rich protoliths were deformed and dismembered, in a manner that mimics in smaller scale the deformation of the host complex, and then were incipiently metamorphosed at blueschistfacies conditions. Eight phases occur as almost monomineralic protoliths and mixtures: rhodochrosite, caryopilite, chlorite, gageite, taneyamalite, braunite, hausmannite, and laminated chert (quartz). Braunite, gageite, and some chlorite and caryopilite layers were deposited as gel-like materials; rhodochrosite, most caryopilite, and at least some hausmannite layers as lutites; and the chert as turbidites of radiolarian sand. Some gel-like materials are now preserved as transparent, sensibly isotropic relies of materials that fractured or shattered when deformed, creating curved surfaces. In contrast, the micrites flowed between the fragments of gel-like materials.

The orebody and most of its constituent minerals have unusually $\mathrm{Mn}$-rich compositions that are described by the system $\mathrm{MnO}-\mathrm{SiO}_{2}-$ $\mathrm{O}_{2}-\mathrm{CO}_{2}-\mathrm{H}_{2} \mathrm{O}$. High values of $\mathrm{Mn} / \mathrm{Fe}$ and $\mathrm{U} / \mathrm{Th}$, and low concentrations of $\mathrm{Co}, \mathrm{Cu}$, and $\mathrm{Ni}$, distinguish the Buckeye deposit from many high-temperature hydrothermal deposits and hydrogenous or diagenetic manganese and ferromanganese nodules and pavements. This chemical signature suggests that ore deposition was related to fluids from the sediment column and seawater. Tungsten is associated exclusively with gageite, in concentrations as high as 80 parts per million. The source of the manganese is unknown; because basalts do not occur near the deposit, it was probably manganese leached from the sediment column by reducing solutions. Low concentrations of calcium ( $\mathrm{CaO}$ approximately 0.6 weight percent) suggest that the host sediments formed beneath the carbonate-compensation depth.

The most probable cause of the microbanding is changing proportions of chemical fluxes supplied to the sediment-seawater interface. The principal fluxes were biogenic silica from the water column, carbon dioxide from organic matter in the sediment column, $\mathrm{O}_{2}$ and other seawater constituents, and $\mathrm{Mn}^{+2}$-bearing fluid. The presence of $\mathrm{Al}_{2} \mathrm{O}_{3}$ and $\mathrm{TiO}_{2}$ (supplied by a detrital flux) in the metashale but not the ore lens suggests rapid ore deposition. Material supply-rate changes were probably due to a complex combination of episodic variations in the hydrothermal flux and periodic flows of radiolarian sand (silica and $\mathrm{CO}_{2}$ fluxes) that may be related to climate variations.
\end{abstract}

Manuscript approved for publication, April 4, 1989.
The processes that form recent marine hydrothermal mounds may be the same as processes that formed the Buckeye deposit. Features common to both include the presence of Mn-oxyhydroxide crusts (corresponding to the Buckeye orebody), a large $\mathrm{Mn} / \mathrm{Fe}$ ratio, low abundances of most minor elements, and small size. The most important differences are the absence of rhodochrosite and manganese silicates, interlayered with oxide, and the absence of adjacent chert in the contemporary deposits. These differences may be due to an absence of the debris of siliceous pelagic organisms, which accumulated in the Buckeye paleoenvironment. Periodic turbidity flows of chert-forming radiolarian sand could provide the changes in the fluxes of silica and organic matter necessary to form manganese carbonate and silicates. Turbidity flows of graywacke indicate proximity to an environment with high relief. A possible paleodepositional environment is an oceanic spreading center approaching a continental margin at which subduction occurred.

\section{INTRODUCTION}

This report documents our initial effort to understand the origin and metamorphism of banded sedimentary manganese formations. The term "manganese formation" (Huebner, 1976) was specifically chosen to emphasize the similarities in mineralogy and texture that are shared by iron formations, such as the Biwabik of Minnesota and the Hammersley of Australia, and some manganese deposits of the Pacific coast region of the United States. In this paper we will describe the petrographic, mineralogical, and chemical characteristics by which a family of sedimentary protoliths can be recognized and will speculate upon their depositional environment, thereby creating a deposit model.

Hundreds of supergene manganese-oxide pods in chert-graywacke terrains of California were prospected during the First and Second World Wars. At first, only supergene oxides could be used as metallurgical-grade oxide ore, so mining of a deposit ceased when the deposit was completely mined or when carbonate and silicates, rather than oxides, were encountered. When it became economic in the 1940's to use rhodochrosite, mining in the larger deposits exposed manganese carbonate, silicates, and primary oxides, all precursors of the supergene oxides. It is these precursors that are the subject of this paper. 
As a group and as individual deposits, the manganese orebodies of California are well documented. Trask and others (1943), Trask (1950), and Trengrove (1960) described the location, occurrence, and production of hundreds of deposits. Taliaferro and Hudson (1943), Crerar and others (1982), and Hein and others (1987) proposed origins for these deposits. We chose to investigate the Buckeye mine, the second largest producer of manganese in California, because its primary (sedimentary or metamorphic) ore is exposed, the deposit is believed to be representative of many deposits in the California Coast Ranges, and an extensive collection of specimens was available as a result of the work of Huebner (1967). Although most ore had been removed (the walls of the enclosing chert are exposed), the north orebody and a nearby prospect-adit were sampled in 1963 (fig. 1). Samples were also obtained from piles of ore during the summer of 1963 and from surface outcrops during 1965.

The nomenclature of manganese-rich phases, particularly the sheet silicates, is arcane but need not be so because many of the Mn phases have compositions analogous to those of better known $\mathrm{Mg}$ or $\mathrm{Fe}$ minerals. Because a major purpose of this report is to present criteria for recognition of similar deposits, we summarize in table 1 the Mn minerals that are mentioned below or that we sought and list the corresponding $\mathrm{Mg}, \mathrm{Fe}$, and $\mathrm{Al}$ endmembers. In compiling this list, we used mineralogical summaries (Fleischer, 1981, 1987; Fleischer and Schafer, 1981, 1983) and their cited references. A detailed discussion of the crystal chemistry of the phases that we observed follows the discussion of the lithologies.

The term "gel-like" is used in this paper to describe materials that resemble the less-than- $0.1-\mu \mathrm{m}$ fine-clay fraction from Lake Abert, Oregon (separated from sample 23de of Jones and Weir, 1983), which we have been able to examine. This material is pale brown, transparent, flows if deformed slowly, and fractures if deformed rapidly or shocked by striking a plastic container that contains the gel-like material upon a hard surface. Because these gel-like materials are largely crystalline, albeit extremely fine grained, they would be expected to have compositions similar to those of their mineral constituent and to recrystallize (coarsen) to form monomineralic or polymineralic layers, depending upon their initial mineralogy.

\section{ACKNOWLEDGMENTS}

This study is an outgrowth of a chapter in the first author's Ph.D. dissertation, written while he was a graduate student at The Johns Hopkins University. Partial support was provided by the University and by NSF Graduate Fellowships. Some laboratory and field expenses were defrayed by NSF grants to H.P. Eugster; unfortunately, he is no longer alive to see what became of the samples. The Buckeye deposits are located on the Willow Springs Ranch; access was made possible by G. Purinton, owner in 1963, and by L. Douglas and M. Hall, owner and foreman, respectively, in 1965. Field assistance was provided by C.E. Beverley (1963) and E.Z. Huebner $(1963,1965)$. At the time of these visits, D.F. Hewett enthusiastically shared his knowledge of, and stories about, California manganese deposits. J.J. Fitzpatrick and J.J. Matzko participated in the early stages of the project's revival at the U.S. Geological Survey (USGS). The continuing dedication of J.J. McGee of the Reston Microprobe Laboratory made feasible the collection of the many microprobe analyses by Flohr. B.F. Jones of the USGS taught us much about seawatersediment interactions and made us aware of the lessthan-0.2- $\mu \mathrm{m}$ smectite gel reported in Jones and Weir (1983). R.A. Koski (USGS) loaned us two thin sections, one of which in shown in figure $5 D$. We greatly appreciate the enthusiastic cooperation of the following staff of the USGS chemical analysis laboratories who turned our "fishing expedition" into a study of the matrix effects in samples that are both highly manganiferous and distinct from the marine nodules: P.A. Aruscavage, M.W. Doughten, J. Fletcher, J.N. Grossman, R.G. Johnson, B. Libby, and H. Kirschenbaum. We benefited immensely. Constructive reviews were provided by P.R. Brett, J. Webster, and E. Force (all USGS) and L. Raymond (Appalachian State University). Brett suggested that serpentinization at low temperature might drive convection through abyssal sediments far removed

Figure 1.-Geologic map and sample locations. A, Distribution of chert-metashale, graywacke-sandstone, and manganese deposits in the Franciscan Complex near the Buckeye and Ladd mines, northern Diablo Range of the central California Coast Ranges. Adapted from Cox and others (in Trask, 1950, pl. 4) and Raymond (1973b, fig. 2). Inset adapted from Bailey and others (1964, pl. 1). Note the association of manganese deposits with chert and the undulatory contacts between chert and graywacke. The Carnegie fault and northern part of the Pegleg fault are parts of the Tesla-Ortigalita fault system. $B$, Geologic sketch map of the vicinity of the Buckeye mine. The base is aerial photography. Subdivision into broken formations follows usage of Raymond (1973a): KJfsg, Sulphur Gulch broken formation; KJfg, Grummett broken formation; KJfo, Oso broken formation. $C$, Location of samples collected from surface outcrops and dumps. Base is identical to that used for $B$. Samples designated $\mathrm{H} x x$ correspond to those labeled $65 \mathrm{H} x x$ in text. Sample B112 is a grab sample from the gulch below (south of) the north orebody and is not plotted. $D$, Location of samples collected from the open cut, 1837- and 1805-ft levels of the north Buckeye orebody. Mine workings and trend of ore lens adapted from maps and sections by Crittenden and others (pl. 18 of Trask, 1950). E, Location of samples collected from exploration adit between the north and south Buckeye orebodies. 


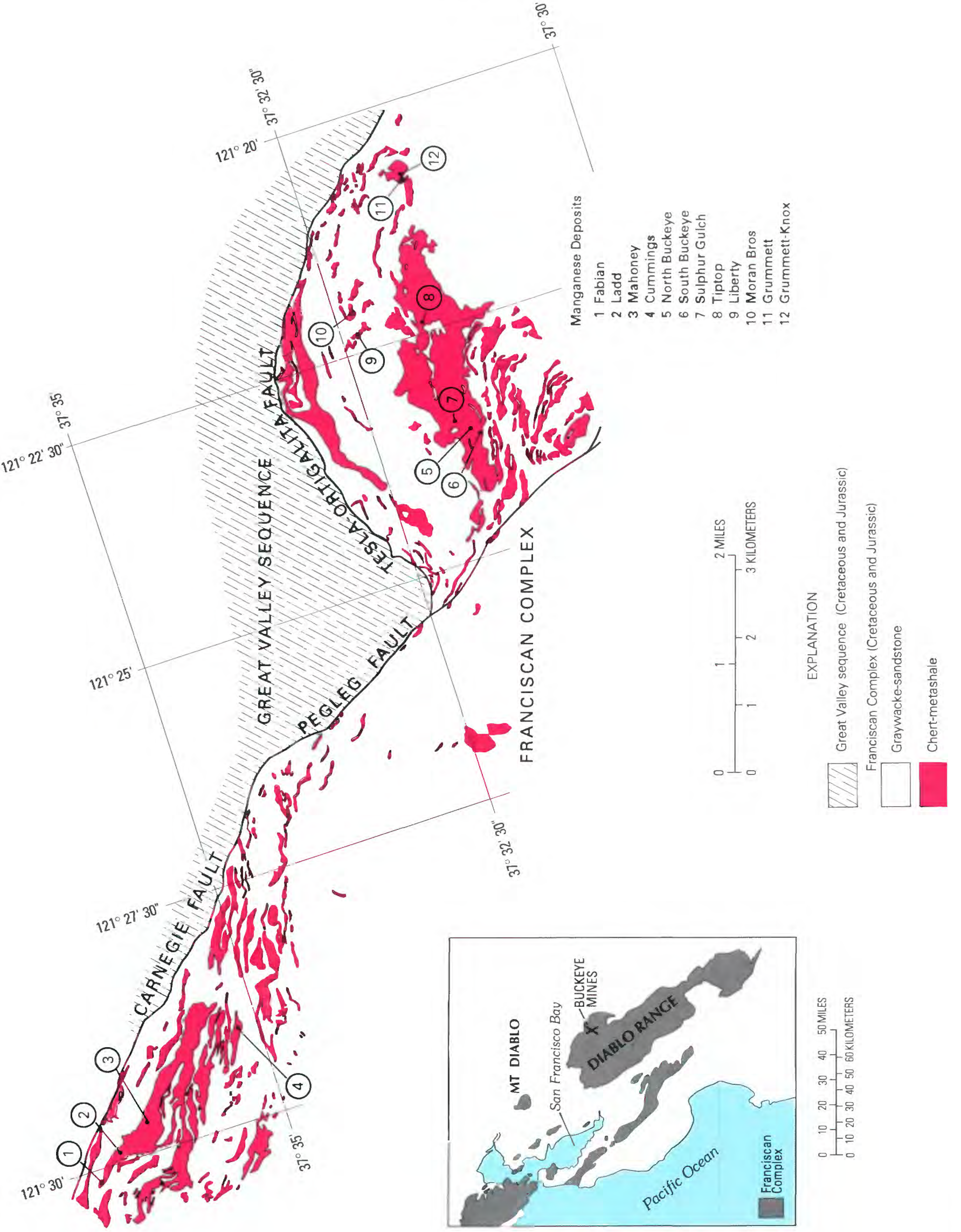



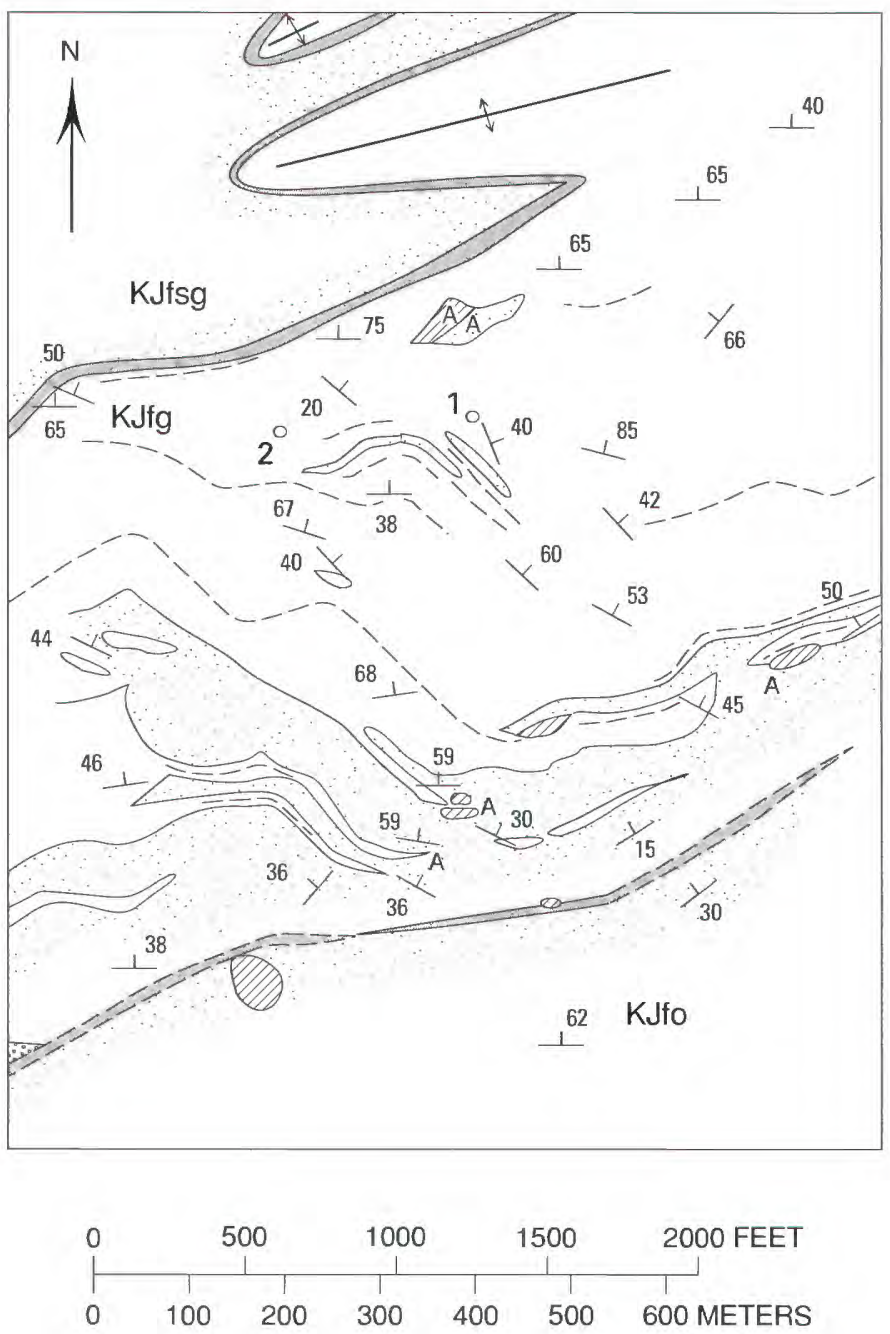

\section{EXPLANATION}

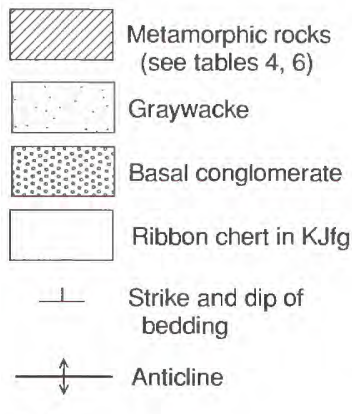

$B$

from a spreading center. Although we did not adopt this suggestion for the Buckeye, serpentinization may be an important factor in the origin of laterally extensive diagenetic deposits. Raymond challenged us to expand our discussions of the relationship between the environment of deposition and accretionary complexes.
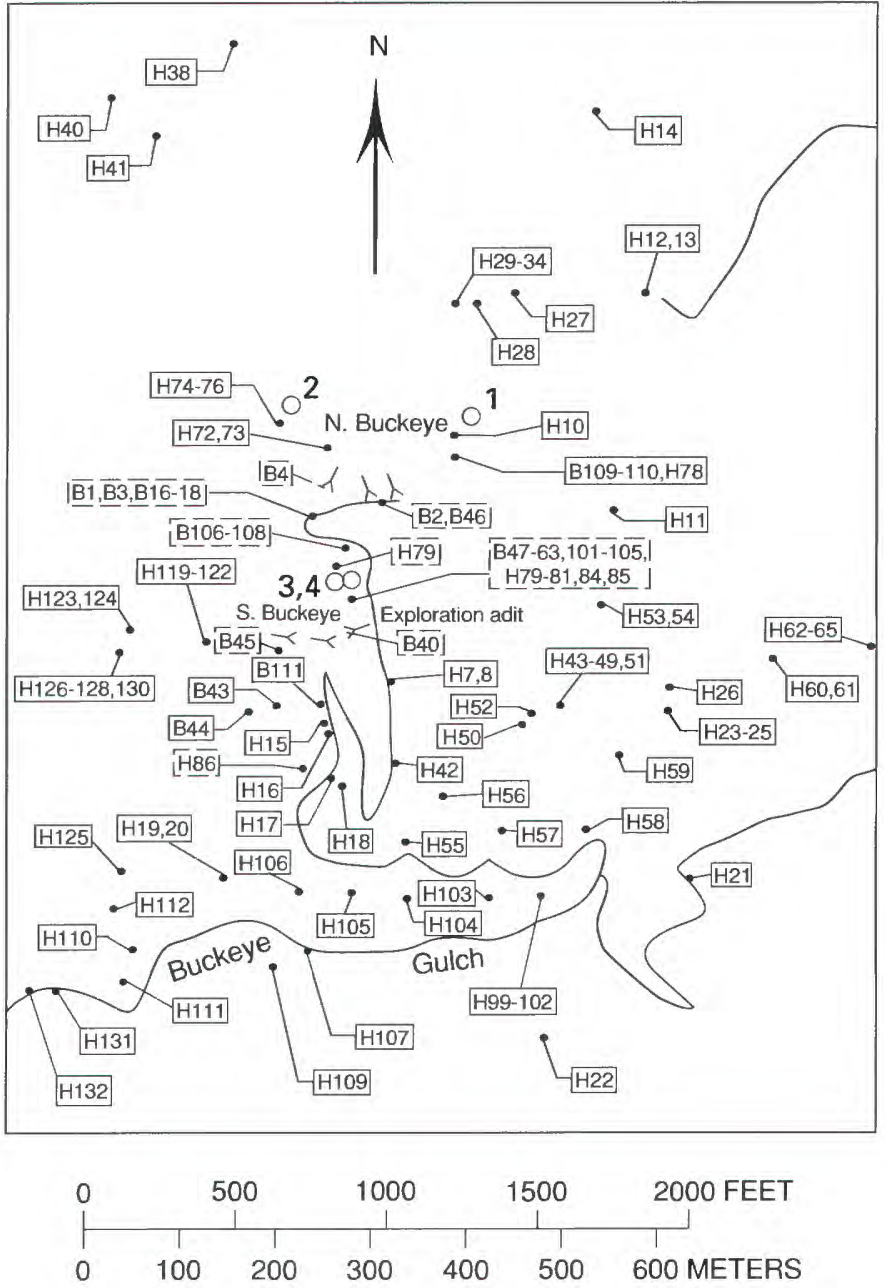

\section{EXPLANATION}

\begin{tabular}{ll|ll}
\hline H109 & Sample from outcrop & 10 & Diamond drill hole \\
\hdashline & $\smile$ & Adit \\
\hdashline & & & Road
\end{tabular}

\section{PREVIOUS WORK}

Previous investigators dealt with aspects of the mineralogy, petrology, chemistry, and genesis of the Buckeye (and similar) deposits, but none has considered all of the different kinds of data that must be integrated to understand deposits such as these. In the following paragraphs we review the observations and data of our predecessors and show that there is still ambiguity about the fundamental nature and origin of the ore.

The most complete description of the California Coast Ranges deposits is by Taliaferro and Hudson (1943) who made frequent reference to the Buckeye mine when discussing the origin of similar deposits. Unique observations were made while ore was being removed. Most 


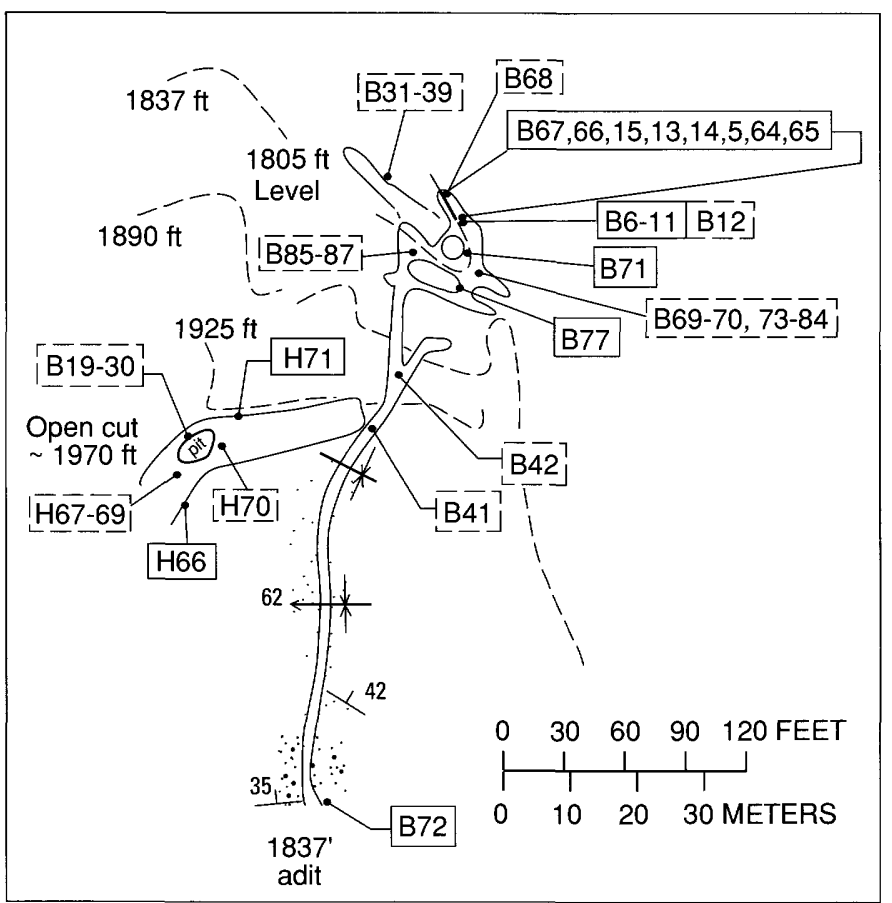

\section{EXPLANATION}

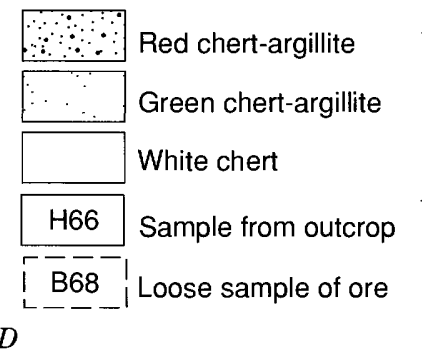

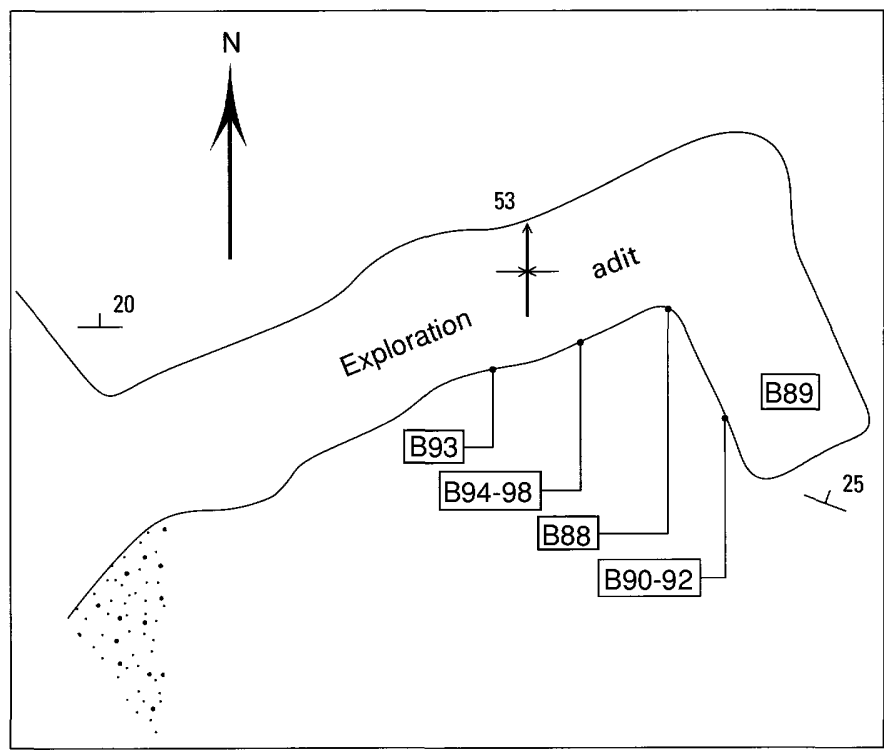

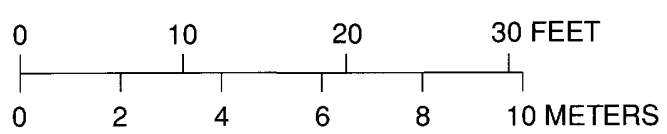

EXPLANANTION

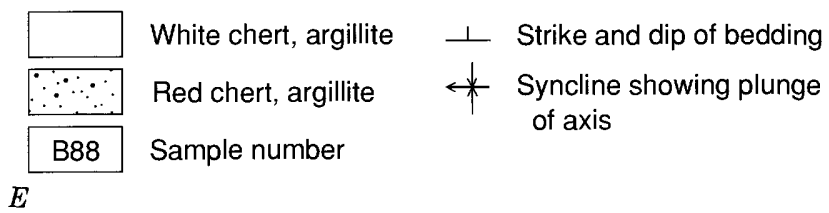

Figure 1.-Continued.

manganese deposits are associated with thick lenses of light-colored massive chert, which in turn are enclosed in darker, rhythmically bedded radiolarian cherts. The converse is not true: the vast majority of massive cherts are not associated with manganese deposits. Many cherts are associated with volcanic flows, but this is not the case near the Buckeye mines. Taliaferro and Hudson thought that the cherts were originally oozes rich in colloidal silica. On becoming a gel the ooze expelled the impurities, thereby concentrating them in what are now the argillaceous interbeds. Thus the rhythmic chert layering was thought to be the product of diagenetic segregation. Presumably, they thought that the precursor to the massive cherts was an ooze so pure that there were insufficient impurities to form argillaceous layers.

Orebodies known to Taliaferro and Hudson formed lenses less than $11 \mathrm{~m}$ thick and less than $240 \mathrm{~m}$ in maximum dimension. Folding and faulting obscured the shape of the orebodies in the plane parallel to the layering, but internally they were banded, being com- posed of smaller lenslike bodies that lay parallel to the layering in the surrounding cherts. These lenses consisted principally of manganese carbonate and silicates. Unfortunately, neither the spatial distribution of these two components within the lens nor the nature of their contact with the surrounding chert was discussed. An important observation, based in part on analysis of thin sections but overlooked by some subsequent investigators, is that fine banding was present in material that Taliaferro and Hudson called manganiferous opal (1943, p. 240). The lenses are now partly recrystallized to pink rhombohedra of rhodochrosite and to yellow, orange, and brown fibers of manganese silicates called bementite. Hausmannite and braunite were uncommon and, because of association with barite and copper, were regarded as having formed during subsequent hydrothermal action. (Fleischer and Richmond (1943) reported the presence of braunite, but not hausmannite, at the Buckeye mine.) Taliaferro and Hudson thought that the deposits were "chemical sediments formed at the same time and in the 
TABLE 1.-Known and hypothetical manganese minerals and common analogues discussed in text $\left[-\right.$, not applicable; $M^{\mathrm{VI}} / T^{\mathrm{IV}}$, ratio of octahedrally coordinated to tetrahedrally coordinated cations]

\begin{tabular}{|c|c|c|c|}
\hline Ideal formula & $\mathrm{M}^{\mathrm{VI}} / \mathrm{T}^{\mathrm{IV}}$ & Fe analogue & $(\mathrm{Mg}, \mathrm{Al}, \mathrm{Ca})$ analogue \\
\hline Rhodochrosite .............. $\mathrm{MnCO}_{3}$ & - & Siderite & Calcite. \\
\hline Hausmannite $\ldots \ldots \ldots \ldots \ldots \ldots \mathrm{Mn}_{3} \mathrm{O}_{4}$ & - & Magnetite & Unknown. \\
\hline Bixbyite $\ldots \ldots \ldots \ldots \ldots \ldots \ldots \mathrm{Mn}_{2} \mathrm{O}_{3}$ & - & Hematite & Unknown. \\
\hline Pyrolusite.............. $\mathrm{MnO}_{2}$ & - & Unknown & Unknown. \\
\hline Todorokite $\ldots \ldots \ldots \ldots \ldots \ldots \mathrm{Mn}^{+2} \mathrm{Mn}_{3}^{+4} \mathrm{O}_{7} \cdot \mathrm{H}_{2} \mathrm{O}$ & - & Unknown & Unknown. \\
\hline Nsutite $\ldots \ldots \ldots \ldots \ldots \ldots \ldots \mathrm{Mn}_{\mathrm{x}}^{+2} \mathrm{Mn}_{1-\mathrm{x}}^{+4} \mathrm{O}_{2-2 \mathrm{x}}(\mathrm{OH})_{2 \mathrm{x}}$ & - & Unknown & Unknown. \\
\hline Braunite..$\ldots \ldots \ldots \ldots \ldots \mathrm{Mn}^{+2} \mathrm{Mn}_{6}^{+3} \mathrm{SiO}_{12}$ & - & Unknown & Neltnerite. \\
\hline Birnessite ................ Na $\mathrm{Na}_{4} \mathrm{Mn}_{14} \mathrm{O}_{27} \cdot 9 \mathrm{H}_{2} \mathrm{O}$ & - & Unknown & Unknown. \\
\hline Vernadite ................. $\left(\mathrm{Mn}^{+4}, \mathrm{Fe}^{+3}, \mathrm{Ca}, \mathrm{Mn}\right)(\mathrm{O}, \mathrm{OH})_{2} \cdot \mathrm{nH}_{2} \mathrm{O}$ & - & Unknown & Unknown. \\
\hline Pyrophanite.............. $\mathrm{MnTiO}_{3}$ & - & Ilmenite & Geikielite. \\
\hline Pennantite $\ldots \ldots \ldots \ldots \ldots \ldots \ldots \mathrm{Mn}_{10} \mathrm{Al}_{2}(\mathrm{Si}, \mathrm{Al})_{8} \mathrm{O}_{20}(\mathrm{OH})_{16}$ & 1.5 & Chamosite & Clinochlore. \\
\hline Gonyerite $\ldots \ldots \ldots \ldots \ldots \ldots \ldots \mathrm{Mn}_{10} \mathrm{Fe}_{2}^{+3}\left(\mathrm{Si}, \mathrm{Fe}^{+3}\right)_{8} \mathrm{O}_{20}(\mathrm{OH})_{16}$ & 1.5 & Unknown & Unknown. \\
\hline Bannisterite $\ldots \ldots \ldots \ldots \ldots \ldots(\mathrm{K}, \mathrm{Ca}) \mathrm{Mn}_{10}(\mathrm{Si}, \mathrm{Al})_{16} \mathrm{O}_{38}(\mathrm{OH})_{8}\left(\mathrm{H}_{2} \mathrm{O}\right)_{2-6}$ & .625 & Unknown & Unknown. \\
\hline Ganophyllite............... (K, Na,Ca $)_{6} \mathrm{Mn}_{24}(\mathrm{Si}, \mathrm{Al})_{40}(\mathrm{O}, \mathrm{OH})_{112}\left(\mathrm{H}_{2} \mathrm{O}\right)_{21}$ & .6 & Unknown & Unknown. \\
\hline Caryopilite $\ldots \ldots \ldots \ldots \ldots \ldots \mathrm{Mn}_{6} \mathrm{Si}_{4} \mathrm{O}_{10}(\mathrm{OH})_{8}$ & 1.5 & Greenalite & Unknown. \\
\hline Bementite............... $\mathrm{Mn}_{7} \mathrm{Si}_{6} \mathrm{O}_{15}(\mathrm{OH})_{8}$ & 1.17 & Unknown & Unknown. \\
\hline Unknown $\ldots \ldots \ldots \ldots \ldots \ldots \ldots \ldots(1 / 2 \mathrm{Ca}, \mathrm{Na})_{0.66} \mathrm{Mn}_{6}^{+2}(\mathrm{Si}, \mathrm{Al})_{8} \mathrm{O}_{20}(\mathrm{OH})_{4}\left(\mathrm{H}_{2} \mathrm{O}\right)_{8}$ & .75 & Unknown & Saponite. \\
\hline Unknown $\ldots \ldots \ldots \ldots \ldots \ldots \ldots(1 / 2 \mathrm{Ca}, \mathrm{Na})_{0.66} \mathrm{Mn}_{4}^{+3}(\mathrm{Si}, \mathrm{Al})_{8} \mathrm{O}_{20}(\mathrm{OH})_{4}\left(\mathrm{H}_{2} \mathrm{O}\right)_{8}$ & .50 & Nontronite & Unknown. \\
\hline Unknown $\ldots \ldots \ldots \ldots \ldots \ldots \mathrm{Mn}_{6} \mathrm{Si}_{8} \mathrm{O}_{20}(\mathrm{OH})_{4}$ & .75 & Unknown & Talc. \\
\hline Unknown $\ldots \ldots \ldots \ldots \ldots \ldots \ldots \mathrm{Mn}_{30} \mathrm{Si}_{40} \mathrm{O}_{96}(\mathrm{OH})_{28}$ & .75 & Minnesotaite & Unknown. \\
\hline Ashley $(1986) \ldots \ldots \ldots \ldots \ldots \ldots \mathrm{K}_{2} \mathrm{Mn}_{6}\left(\mathrm{Mn}^{+3}, \mathrm{Al}_{2}\right)_{2} \mathrm{Si}_{6} \mathrm{O}_{20}(\mathrm{OH})_{4}$ & .75 & Biotite & Phlogopite. \\
\hline Unknown $\ldots \ldots \ldots \ldots \ldots \ldots \ldots \mathrm{K}_{2} \mathrm{Mn}_{4}^{+3}\left(\mathrm{Mn}^{+3}, \mathrm{Al}_{2}\right)_{2} \mathrm{Si}_{6} \mathrm{O}_{22}(\mathrm{OH})_{4}$ & .50 & Unknown & Muscovite. \\
\hline Akatoreite $\ldots \ldots \ldots \ldots \ldots \ldots \mathrm{Mn}_{9} \mathrm{Al}_{2} \mathrm{Si}_{8} \mathrm{O}_{23}(\mathrm{OH})_{9}$ & .90 & Unknown & Unknown. \\
\hline Piemontite $\ldots \ldots \ldots \ldots \ldots \ldots \ldots \mathrm{Ca}_{2} \mathrm{Mn}_{2}^{+3} \mathrm{AlSi}_{3} \mathrm{O}_{12}(\mathrm{OH})$ & 1.0 & Epidote & Clinozoisite. \\
\hline Gageite $\ldots \ldots \ldots \ldots \ldots \ldots \ldots \mathrm{Mn}_{5} \mathrm{Si}_{2} \mathrm{O}_{9-\mathrm{x}}(\mathrm{OH})_{2 \mathrm{x}}$ & 2.5 & Unknown & Balangeroite. \\
\hline Taneyamalite............. NaMn ${ }_{12} \mathrm{Si}_{12} \mathrm{O}_{30}(\mathrm{OH})_{14}$ & 1.0 & Howieite & Unknown. \\
\hline Unknown $\ldots \ldots \ldots \ldots \ldots \ldots \ldots \mathrm{Mn}_{6}\left(\mathrm{Mn}^{+3}, \mathrm{Al}_{3}\right)_{3} \mathrm{Si}_{6} \mathrm{O}_{20}(\mathrm{OH})_{5}$ & 1.5 & Deerite & Unknown. \\
\hline Unknown $\ldots \ldots \ldots \ldots \ldots \ldots \ldots \mathrm{K}_{0-1} \mathrm{Mn}_{13}(\mathrm{Al}, \mathrm{Si})_{18} \mathrm{O}_{42}(\mathrm{OH})_{14}$ & .72 & Zussmanite & Unknown. \\
\hline Parsettensite $\ldots \ldots \ldots \ldots \ldots \ldots \mathrm{K}(\mathrm{Mn}, \mathrm{Al})_{7} \mathrm{Si}_{8} \mathrm{O}_{20}(\mathrm{OH})_{8} \cdot 2 \mathrm{H}_{2} \mathrm{O}$ & .67 & Unknown & Unknown. \\
\hline Unknown $\ldots \ldots \ldots \ldots \ldots \ldots \ldots \ldots \mathrm{K}_{5} \mathrm{Mn}_{48}\left(\mathrm{Si}_{63} \mathrm{Al}_{9}\right) \mathrm{O}_{168^{\prime}}(\mathrm{OH})_{48}$ & .67 & Ferrostilpnomelane & Lennilenapeite. \\
\hline Unknown $\ldots \ldots \ldots \ldots \ldots \ldots \ldots \mathrm{K}_{5} \mathrm{Mn}_{48}^{+3}\left(\mathrm{Si}_{63} \mathrm{Al}_{9}\right) \mathrm{O}_{216} \cdot 36 \mathrm{H}_{2} \mathrm{O}$ & .67 & Ferristilpnomelane & Unknown. \\
\hline Spessartine $\ldots \ldots \ldots \ldots \ldots \ldots \mathrm{Mn}_{3} \mathrm{Al}_{2}\left(\mathrm{SiO}_{4}\right)_{3}$ & 1.67 & Almandine, andradite & Pyrope, etc. \\
\hline Calderite. .............. $\mathrm{Mn}_{3}^{+2} \mathrm{Fe}_{2}^{+3}\left(\mathrm{SiO}_{4}\right)_{3}$ & 1.67 & Unknown & Unknown. \\
\hline Unknown $\ldots \ldots \ldots \ldots \ldots \ldots \ldots \mathrm{Mn}_{3}\left(\mathrm{SiO}_{4}\right)(\mathrm{F}, \mathrm{OH})_{2}$ & 3.0 & Unknown & Norbergite. \\
\hline Alleghanyite $\ldots \ldots \ldots \ldots \ldots \ldots \mathrm{Mn}_{5}\left(\mathrm{SiO}_{4}\right)_{2}(\mathrm{OH})_{2}$ & 2.5 & Unknown & Chondrodite. \\
\hline Manganhumite. $\ldots \ldots \ldots \ldots \ldots \mathrm{Mn}_{7}\left(\mathrm{SiO}_{4}\right)_{3}(\mathrm{OH})_{2}$ & 2.33 & Unknown & Humite. \\
\hline Leucophoenicite $\ldots \ldots \ldots \ldots \ldots \mathrm{Mn}_{7}\left(\mathrm{SiO}_{4}\right)_{3}(\mathrm{OH})_{2}$ & 2.33 & Unknown & Unknown. \\
\hline Sonolite................ $\mathrm{Mn}_{9}\left(\mathrm{SiO}_{4}\right)_{4}(\mathrm{OH}, \mathrm{F})_{2}$ & 2.25 & Unknown & Clinohumite. \\
\hline Tephroite ............... $\mathrm{Mn}_{2} \mathrm{SiO}_{4}$ & 2.0 & Fayalite & Forsterite. \\
\hline Donpeacorite $\ldots \ldots \ldots \ldots \ldots \ldots \mathrm{MnMgSi}_{2} \mathrm{O}_{6}$ & 1.0 & Ferrosilite & Enstatite. \\
\hline Kanoite................ $\mathrm{MnMgSi}_{2} \mathrm{O}_{6}$ & 1.0 & Clinoferrosilite & Pigeonite. \\
\hline Johannsenite $\ldots \ldots \ldots \ldots \ldots \mathrm{CaMnSi}_{2} \mathrm{O}_{6}$ & 1.0 & Hedenbergite & Diopside. \\
\hline Ashley $(1986) \ldots \ldots \ldots \ldots \ldots \mathrm{NaMn}^{+3} \mathrm{Si}_{2} \mathrm{O}_{6}$ & 1.0 & Acmite & Jadeite. \\
\hline Rhodonite.............. CaMn ${ }_{4}\left(\mathrm{SiO}_{3}\right)_{5}$ & 1.0 & Ferrobustamite & Unknown. \\
\hline Pyroxmangite $\ldots \ldots \ldots \ldots \ldots \ldots \mathrm{Mn}_{7}\left(\mathrm{SiO}_{3}\right)_{7}$ & 1.0 & Pyroxferroite & Unknown. \\
\hline Inesite $\ldots \ldots \ldots \ldots \ldots \ldots \ldots \mathrm{Ca}_{2} \mathrm{Mn}_{7} \mathrm{Si}_{10} \mathrm{O}_{28}(\mathrm{OH})_{2}\left(\mathrm{H}_{2} \mathrm{O}\right)_{5}$ & .90 & Unknown & Unknown. \\
\hline Santaclaraite $\ldots \ldots \ldots \ldots \ldots \ldots \mathrm{CaMn}_{4} \mathrm{Si}_{5} \mathrm{O}_{14}(\mathrm{OH})(\mathrm{OH}) \cdot \mathrm{H}_{2} \mathrm{O}$ & 1.0 & Unknown & Unknown. \\
\hline Nambulite $\ldots \ldots \ldots \ldots \ldots \ldots(\mathrm{Li}, \mathrm{Na}) \mathrm{Mn}_{4} \mathrm{Si}_{5} \mathrm{O}_{14}(\mathrm{OH})$ & .80 & Unknown & Unknown. \\
\hline Manganbabingtonite. ......... $\mathrm{Ca}_{2} \mathrm{MnFe}^{+3} \mathrm{Si}_{5} \mathrm{O}_{14}(\mathrm{OH})$ & .80 & Babingtonite & Unknown. \\
\hline Marsturite $\ldots \ldots \ldots \ldots \ldots \ldots \mathrm{Na}_{2} \mathrm{Ca}_{2} \mathrm{Mn}_{6} \mathrm{Si}_{10} \mathrm{O}_{28}(\mathrm{OH})_{2}$ & .80 & Unknown & Unknown. \\
\hline Tirodite.................. $\mathrm{Mn}_{2} \mathrm{Mg}_{5} \mathrm{Si}_{8} \mathrm{O}_{22}(\mathrm{OH})_{2}$ & .88 & Grunerite & Cummingtonite. \\
\hline Dannemorite $\ldots \ldots \ldots \ldots \ldots \ldots \mathrm{Mn}_{2} \mathrm{Fe}_{5} \mathrm{Si}_{8} \mathrm{O}_{22}(\mathrm{OH})_{2}$ & .88 & Grunerite & Cummingtonite. \\
\hline Kozulite $\ldots \ldots \ldots \ldots \ldots \ldots \ldots \mathrm{NaNa}_{2} \mathrm{Mn}_{4}\left(\mathrm{Fe}^{+3}, \mathrm{Al}\right) \mathrm{Si}_{8} \mathrm{O}_{22}(\mathrm{OH})_{2}$ & .88 & Arfvedsonite & Magnesioarfvedsonite. \\
\hline Tsilaisite...................... & 1.0 & Schorl & Elbaite. \\
\hline Saneroite $\ldots \ldots \ldots \ldots \ldots \ldots \ldots \mathrm{Na}_{2} \mathrm{Mn}_{10}(\mathrm{Si}, \mathrm{V})_{12} \mathrm{O}_{34}(\mathrm{OH})_{4}$ & .83 & Unknown & Unknown. \\
\hline Welinite $\ldots \ldots \ldots \ldots \ldots \ldots \ldots \mathrm{Mn}_{6}(\mathrm{~W}, \mathrm{Mg})_{2} \mathrm{Si}_{2}(\mathrm{O}, \mathrm{OH})_{14}$ & 4.0 & Unknown & Unknown. \\
\hline
\end{tabular}


TABLE 1.-Known and hypothetical manganese minerals and common analogues discussed in text-Continued $\left[-\right.$, not applicable; $\mathbf{M}^{\mathrm{VI}} / \mathbf{T}^{\mathrm{IV}}$, ratio of octahedrally coordinated to tetrahedrally coordinated cations]

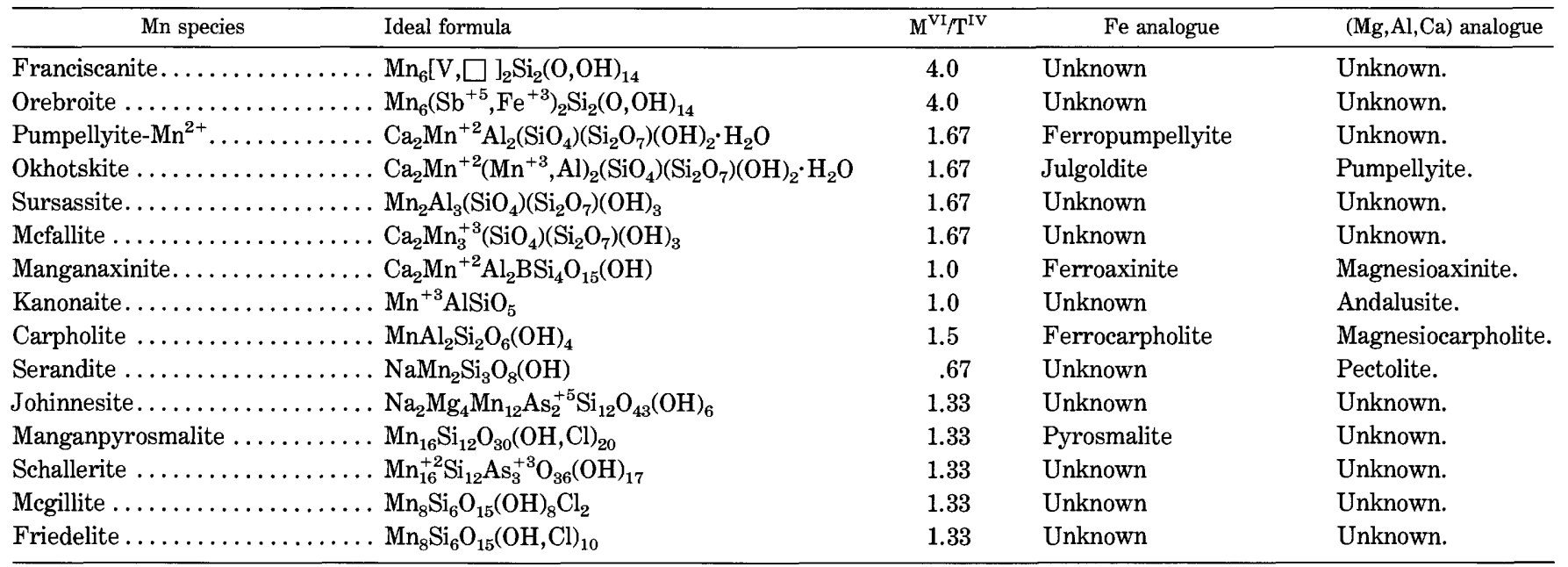

same marine environment as the cherts" (p. 272). In their interpretation, the cherts were deposited as siliceous oozes and the manganese-rich materials as fine-grained gray manganese carbonate and thinly banded, resinous, almost optically isotropic manganiferous opal containing 14 weight percent $\mathrm{H}_{2} \mathrm{O}$. Silica and manganese were thought to be associated with volcanism, and the manganese was supplied as carbonate and oxides. The massive cherts and the manganese orebodies represent periods of rapid deposition. After examining many deposits, these authors found no evidence for replacement of chert by ore (Taliaferro and Hudson, 1943, p. 273).

Trask and Pierce (in Trask, 1950, p. 211-221) focused on the Ladd-Buckeye area. Their observations were based in part on fieldwork during 1940-42, when the deposit was actively mined. Ore was always associated with white, usually massive, chert. They reported two kinds of ore: (1) massive, fine-grained gray rhodochrosite with bementite layers and minor hausmannite, rhodonite, and braunite and (2) a mixture of rhodochrosite and bementite, disseminated in chert. This second type forms a thin transition zone between massive carbonate and chert at the sides and ends of the lenses. Trask and Pierce thought that the pinching and swelling of the chert bodies reflected deposition in marine basins. Recognition that the red color of chert represents an oxidized state of iron and that rhodochrosite represents a reduced state of manganese led them to propose that the manganese ores and white chert were formed in reducing basins and the oxidized chert formed under shallower marine conditions. The generally sharp contacts with the surrounding chert, at both the sides and the extremities of the manganiferous lenses, were thought to be caused by presumed distinct mechanical consistencies of the manganiferous sediments and silica gel. Hydrothermal activ- ity was thought to be indicated by the presence of quartz veins and cinnabar, by the lack of bedding and nonuniform crystallinity of the gray rhodochrosite, and by the presence of hausmannite, rhodonite, and braunite. But despite this hydrothermal activity, the manganese did not migrate into the wall rocks.

Subsequent observers also found massive ore. Trask (1950, p. 287-288) reported that, in 1942, massive ore was exposed in the north and south Buckeye orebodies. Crittenden (in Trask, 1950, p. 288-289) examined the orebody in 1944, at which time the primary ore was well exposed at levels subsequently accessible to Huebner (1967) and Hein and others (1987). Crittenden reported that along strike, the north Buckeye orebody was defined by change in manganese content rather than thickness, gradually changing to chalcedonic quartz and thence to chert. This is the only report of a gradational contact from the orebody into the chert. Crittenden described the ore as "an exceedingly massive and intimate mixture" (p. 288) of (in decreasing abundance) gray rhodochrosite, massive braunite and possibly hausmannite, brown to tan manganese silicates, pink rhodochrosite, neotocite, rhodonite, inesite, and sulfides. The older minerals (p. 289) were gray rhodochrosite, braunite, hausmannite (if present), and manganiferous chert (presumably neotocite). Of these minerals, gray carbonate was regarded as "original" (p. 288) and the braunite and hausmannite as possibly metamorphic. Younger minerals regarded as clearly hydrothermal in origin (p. 289) were pink rhodochrosite, quartz, rhodonite, inesite, sulfides including molybdenite, brown and tan manganese silicates, and neotocite. Again, the spatial distribution of these minerals within the ore lens was not given.

The property was drilled by the Bureau of Mines in 1940-41. Volin and Matson (1949) reported that the ore 
consisted of rhodochrosite, bementite, rhodonite, psilomelane, and pyrolusite. The last two minerals are undoubtedly supergene. The primary ore was a mixture of carbonates and silicates, but layering was not noted. The boundary between the primary ore and chert was distinct. Four drill holes encountered only low concentrations (1-11 percent by weight) of $\mathrm{Mn}$ and demonstrated that the high grade of the mined orebodies did not continue downward or along strike. Subsequently Trengrove (1960) summarized this work as indicating that "a large mineralized zone of low-grade manganiferous chert" surrounded the north orebody.

Huebner (1967) described the mineral associations, using X-ray powder diffractometry and thin sections to identify the minerals. He determined that the major ore-forming minerals were hausmannite, braunite, rhodochrosite with lattice constants nearly identical to those of pure $\mathrm{MnCO}_{3}$, and what had been called bementite. He found that bementite from the Buckeye and elsewhere was a mixture of phases probably related to septechlorite ( $7 \AA$, serpentine), chlorite $(14 \AA)$, and the pyrosmalite group of minerals. He also found $9 \AA$ and $6.9 \AA$ reflections, now recognized as due to the presence of taneyamalite (Matsubara, 1981) and gageite (Phillips, 1911), and in thin sections observed pseudomorphs "more slender than most rhodonite crystals" (p. 66) of a mineral now known as santaclaraite (Erd and Ohashi, 1984). Unlike other workers, he did not find rhodonite, inesite, or neotocite. Huebner did not explicitly address the massiveness of the ores, but it is clear from his descriptions and photographs that he encountered both layered and massive ore. He recognized that the deposit had an unusual bulk composition that could be closely modelled by the system $\mathrm{MnO}-\mathrm{SiO}_{2}-\mathrm{O}_{2}-\mathrm{CO}_{2}-\mathrm{H}_{2} \mathrm{O}$. He suggested that the Buckeye deposits and enclosing cherts formed as chemical sediments in local depressions, rapidly precipitated from thermal waters in the intervals between turbidite (graywacke) units. Rapid deposition of the manganiferous material and adjacent silica diluted the supply of clastics, represented by the argillaceous layers within the chert rhythmites, providing an explanation for the high purity of the deposit and the absence of shale interbeds in the massive chert adjacent to the ore. In the absence of associated volcanic rocks and in view of the rapid deposition, he did not favor the leaching of extrusive flows as the source of the manganese. Rather, because of the high $\mathrm{Mn} / \mathrm{Fe}$ ratio, he preferred a hydrothermal source and thought that the carbonate and silicates resulted from mixing of hydrothermal and oceanic waters. Most important, he noted that the Mn-rich sediments at the Buckeye were relatively oxidized and proposed that their high intrinsic oxygen fugacity values were inherited from initially oxidized sediments. This concept was later developed more clearly (Huebner, 1969, 1976).

Hewett (1972) reviewed the occurrences and significance of hausmannite and braunite, concluding that hausmannite formed from hypogene (rising) solutions, whereas braunite could be either hypogene or supergene. In discussing the manganese deposits of the California Coast Ranges, Hewett stated that (p. 87) "layers or lenses of nearly pure manganese carbonate and thin layers of hydrous manganese silicate (neotocite or 'manganese opal') were laid down either in or near persistent layers of chert. Under the influence of later hydrothermal solutions at the Buckeye deposits, the carbonate was thought to alter to hausmannite and the hausmannite to bementite and neotocite; braunite has also been identified in this assemblage." Clearly, Hewett saw the layered nature of the ore and thought that carbonate was primary, that opaline material was both primary and formed by alteration of carbonate, and that all hausmannite and braunite were formed by alteration of earlier formed minerals.

Raymond (1974) discussed the lithologies of the Mt. Oso area of the Diablo Range, which includes the Buckeye mine, and advocated a depositional environment that combined an abyssal ocean floor or trench with an ocean ridge. The manganese deposits were not discussed, but subsequently Raymond (1977) placed the Ladd-Buckeye district in the context of a seafloor spreading center.

Crerar and others (1982) initiated a detailed geochemical study of manganese deposits of the Franciscan Complex. They considered the 800 known deposits to be similar and focused on two deposits in northern California, the Blue Jay and South Thomas mines. Crerar and others proposed an origin involving hydrothermal processes analogous to those forming the mounds near the Galapagos rift (Corliss and others, 1978). Among the principal lines of evidence cited are the linear distribution of orebodies and the fact that massive ore is devoid of detritus, is depleted in $\mathrm{Fe}$ and some trace elements relative to marine nodules, and has rare-earth-element (REE) patterns similar to patterns thought to be of hydrothermal origin. High heat flow associated with a spreading center was assumed to provide the energy needed to drive the hydrothermal system. Crerar and others favored deposition at either a midocean ridge or back-arc basin.

Stable-isotope data for rhodochrosite from the Buckeye mine were provided by Hodgson (1966) and Yeh and others (1985). Highly negative $\delta^{13} \mathrm{C}_{\mathrm{PDB}}$ values of -45 to -54 per mil (referred to Peedee belemnite) were interpreted as indicating that the $\mathrm{CO}_{2}$ was derived by the oxidation of methane (Hathaway and Degens, 1969). Because this conclusion does not depend upon partitioning of carbon isotopes between fluid and unusual phases 
with unknown behavior, we accept an origin for the $\mathrm{CO}_{3}^{2-}$ that involves decomposition of organic matter. From a single $\delta^{18} \mathrm{O}_{\text {SMow }}$ value $(+19.5$ per mil, referred to standard mean ocean water) for a rhodochrosite sample assumed to have been deposited from seawater, Yeh and others (1985) assigned a temperature of formation of 75 ${ }^{\circ} \mathrm{C}$. From $\delta^{18} \mathrm{O}_{\text {SMow }}$ values of 18.7 to 26.6 for eight rhodochrosite samples from deposits within the Franciscan Complex, Hein and Koski (1987) obtained temperatures of formation of 12 to $120^{\circ} \mathrm{C}$. The significance of these temperatures is in doubt because the fractionation factor for rhodochrosite precipitation is uncertain (see discussion by Okita and others, 1988, p. 2683) and because, as we will show, all rhodochrosite from the Buckeye deposit observed by us is admixed with other phases of unknown oxygen isotope fraction behavior and all samples of Buckeye rhodochrosite observed by us are at least partially recrystallized.

Huebner and others (1986a) briefly described mineralogical banding and the presence of relic gels (the gel-like materials in this report) in the Buckeye deposit. Carbonate mud, interlayered with silicate and oxide gels, was deposited at the sediment-seawater interface. The layering was thought to have been caused by relatively rapid variations in the supply fluxes and may have been climatically induced.

Hein and others (1987) provided chemical, mineralogical, and isotopic data for the Buckeye and adjacent Ladd deposits. They cited Huebner (1967) for observing abundant hausmannite and Erd and Ohashi (1984) for "rare" santaclaraite, apparently because they observed neither mineral in their own samples. Because we observed these minerals in many samples collected at the Buckeye, we believe that sampling by Hein and coworkers may not have been as comprehensive as that of Huebner (1967). They proposed that the Buckeye and Ladd deposits formed in a deep basin at a continental margin by replacement of thin turbidites of radiolarian sand by carbonate. The massive chert, which consists of laminated chert without argillaceous interbeds, was thought to have formed from silica released by this replacement process, but the composite nature of the massive chert was not explained. Because opal-CT was reported to occur in the manganese ores but not in the surrounding rocks, this replacement process was thought to occur at less than $80{ }^{\circ} \mathrm{C}$ and at a depth of $100-700 \mathrm{~m}$ in the sediment pile. Hein and others believed that the manganese was originally derived from manganese oxides and oxyhydroxides dispersed in adjacent chert-metashale layers, but by comparison with the compositions of average shales, argillites, and cherts (Pettijohn, 1957), we do not find that the chert-argillites of the LaddBuckeye district are depleted in Mn.
Hein and Koski (1987) summarized available stableisotope data for the manganese deposits of the Franciscan Complex, including the Ladd and Buckeye deposits. The dominant ore mineral was reported to be rhodochrosite; some samples contained braunite and bementite; and kutnahorite, manganiferous calcite, pennantite, serandite, and sursassite were reported to be less abundant. No mention was made of compositional banding. They reported the "existence of replacement textures of rhodochrosite and silica polymorphs" (p. 725) but gave no examples. In their preferred scenario, manganese was originally deposited within the rhythmic chert sequences as hydrogenous oxides and oxyhydroxides. During diagenesis, buried organic matter produced $\mathrm{CH}_{4}$ that rose into the overlying sediments and was oxidized, in situ, by the oxides and oxyhydroxides, forming $\mathrm{CO}_{2} . \mathrm{CO}_{2}, \mathrm{CH}_{4}$, and reduced manganese moved through fluids produced by compaction and silica dehydration to form rhodochrosite at or below the zone of sulfate reduction and sulfide precipitation, below the seawater-sediment interface. In their model, it is not clear why rhodochrosite did not form at the same time and place at which the oxides and oxyhydroxides within the sediment column were reduced. A replacement origin was implied, but the internal structure and compositional diversity of the orebody were not explained.

Most early investigators regarded the gray manganese carbonate and manganiferous opal as chemically precipitated sediments, but in recent work Hein and others (1987) and Hein and Koski (1987) concluded that the carbonate is the product of a replacement process. Most investigators also appeal to later hydrothermal processes to form the diverse mineralogy, but Huebner (1967; $1986 a, b)$ interpreted this diversity to be a feature of the sedimentary environment. Although there are some reports of banded or layered ore at the Ladd and Buckeye mines, most reports are of massive ore at the working face of the Buckeye mine. The recent papers by Hein and his coworkers make no reference to layered ore. If similar deposits or their metamorphosed equivalents are to be recognized elsewhere, it is essential that the internal structure, compositional diversity, and mineralogy be known.

\section{METHODOLOGY}

Sample locations are shown in figure 1. Data were obtained by using transmitted and reflected light optical microscopy, X-ray powder diffractometry (XPD), electron-microprobe analysis (EMP), and chemical bulk analyses. Because the manganese-rich materials are heterogeneous, it was necessary to examine a large number of samples. We examined 77 polished thin sections, 37 
covered thin sections, and 24 polished blocks. We crushed 87 samples for bulk chemical or X-ray diffraction analyses. Each crushed sample represents a single lithologic type, and most were immediately adjacent to material used for a thin section. Because much of the ore consists of thin layers, many of these crushed samples were less than $2 \mathrm{~g}$ in weight. Approximately 33 additional small samples were systematically examined by $\mathrm{XPD}$. Thus, we were able to integrate diverse kinds of measurements made on essentially identical material. The seven samples chemically analyzed for this report received special handling. Possible $\mathrm{Fe}, \mathrm{Co}, \mathrm{Cu}, \mathrm{Mn}, \mathrm{Ni}$, or $\mathrm{Zn}$ contamination by the saw blades was reduced by grinding sawed surfaces with silicon-carbide grit followed by cleaning ultrasonically in deionized water and acetone. These samples were crushed in a hardened steel mortar ( $\mathrm{Fe}, \mathrm{Cr}$ ) and ground with an agate mortar and pestle. To reduce sample-to-sample cross contamination, the first crushed material for each sample was set aside and used for XPD rather than trace-element chemical analyses. The bulk chemical analytical methods are summarized in Baedecker (1987). Total contamination (by the process of sawing, crushing, and grinding) and cross contamination (by the previous sample) were investigated by subjecting spectroscopically pure silica glass to identical procedures (both before and after the aforementioned seven samples). The second-crushed silica glasses contained less than $4 \mathrm{ppm} \mathrm{Cr}$, less than $50 \mathrm{ppm} \mathrm{Fe}$, and less than $1,600 \mathrm{ppm} \mathrm{Mn}$, concentrations which are much lower than those in the protoliths, indicating that contamination was not a significant factor. We are confident that observed large differences in trace-element concentrations of our Mn-rich samples are real.

The X-ray diffractometer used $\mathrm{CuK \alpha}$ radiation, a proportional counter, and pulse-height analysis that effectively discriminated against $\mathrm{MnK} \alpha$ fluorescence from $\mathrm{Mn}$-rich samples. Even so, the sheet silicates gave such poor-quality patterns that useful unit-cell dimensions could not be obtained. (Attempts to obtain good patterns with a Hague-Guinier camera equipped with a monochromator were even less successful, perhaps because, in the Guinier technique, X-rays pass through the powdered sample rather than reflect from its surface.) The goniometer divergence, receiving, and antiscatter slits were $1^{\circ}, 0.1 \mathrm{~mm}$, and $1^{\circ}$, respectively; the radius was $170 \mathrm{~mm}$; and the takeoff angle was $6^{\circ}$. At a $2 \theta$ scanning rate of $1^{\circ}$ per minute, the patterns routinely yield a crystallinity index (Murata and Norman, 1976) of 10.5 to 11.5 for powder obtained by crushing and grinding (to pass 200-mesh screen) a large quartz crystal of quality suitable for electronic oscillators.

Electron microprobe analyses were performed on a unit with 8 wavelength-dispersive channels operated at $15 \mathrm{kV}$ and $100 \mathrm{nA}$ beam current (15 nA nominal specimen
TABLE 2. - Standards used for electron microprobe analysis of samples from the Buckeye deposit, California Coast Ranges [See Huebner and Woodruff (1985) for fuller explanation; na, not analyzed]

\begin{tabular}{|c|c|c|c|}
\hline \multirow{2}{*}{ Element } & \multicolumn{3}{|c|}{ Phase analyzed } \\
\hline & Oxides & Carbonates & Silicates \\
\hline $\mathrm{Na} \ldots \ldots \ldots$ & FSLC & na & FSLC \\
\hline $\mathrm{Mg} \ldots \ldots \ldots$ & OXTB & CDOS & PXEN \\
\hline $\mathrm{Al} . . . \ldots \ldots$ & $\mathrm{OXGH}$ & na & FSLC \\
\hline $\mathrm{Si} \ldots \ldots \ldots$ & FSLC & na & FSLC \\
\hline $\mathrm{K} \ldots \ldots \ldots$ & na & na & FSBO, MSFP ${ }^{1}$ \\
\hline $\mathrm{Ca} \ldots \ldots \ldots$ & FSLC & CDOS & FSLC \\
\hline $\mathrm{Ti} \ldots \ldots \ldots$ & OXIL & na & SPHC \\
\hline$V \ldots \ldots \ldots$ & OXVA & OXVA & OXVA \\
\hline Cr......... & OXTB & na & OXTB, OXBU \\
\hline $\mathrm{Mn} \ldots \ldots \ldots$ & OXPA & CRAP & OLST \\
\hline $\mathrm{Fe} \ldots \ldots \ldots$ & OXIL & CSIG & OLSF, MBLM \\
\hline Co $\ldots . . .$. & OLCO & na & na \\
\hline Ni.......... & OLNI & OXNC & OLNI \\
\hline $\mathrm{Zn} \ldots \ldots \ldots$ & $\mathrm{OXGH}$ & $\mathrm{OXGH}$ & $\mathrm{OXGH}$ \\
\hline $\mathrm{Sr} \ldots \ldots \ldots \ldots$ & na & CSTR & na \\
\hline $\mathrm{Ba} \ldots \ldots \ldots$ & GLBA & GLBA & GLBA $^{1}$ \\
\hline$F \ldots \ldots \ldots$ & na & na & MSFP $^{1}$ \\
\hline As $\ldots \ldots \ldots$ & $\mathrm{OXAS}^{2}{ }^{2} \mathrm{ARDN}^{2}$ & na & na \\
\hline
\end{tabular}

Explanation of acronyms

ARDN........... Ardennite, Pennsylvania State University Standard 5-114.

CDOS ......... Dolomite, Oberdorf, Austria.

CRAP ........... Rhodochrosite, Alma Park, N. Mex.

CSIG........... Siderite, Ivigtut, Greenland.

CSTR .......... Strontianite, Oberdorf, Austria.

FSBO .......... Orthoclase, St. Lawrence Co., N.Y.

FSLC .......... Labradorite feldspar, Lake County, Oreg.

GLBA .......... Synthetic barium-bearing glass.

MBLM ......... Biotite, Lemhi, Idaho.

MSFP ......... Synthetic fluor-phlogopite, $\mathrm{KMg}_{3} \mathrm{AlSi}_{3} \mathrm{O}_{10} \mathrm{~F}_{2}$.

OLCO ......... Synthetic $\mathrm{Co}_{2} \mathrm{SiO}_{4}$.

OLNI .......... Synthetic $\mathrm{Ni}_{2} \mathrm{SiO}_{4}$.

OLSF $\ldots \ldots \ldots \ldots$ Synthetic fayalite, $\mathrm{Fe}_{2} \mathrm{SiO}_{4}$.

OLST $\ldots \ldots \ldots \ldots$ Synthetic tephroite, $\mathrm{Mn}_{2} \mathrm{SiO}_{4}$.

OXAS .......... Synthetic $\mathrm{As}_{2} \mathrm{O}_{3}$, National Bureau of Standards Standard Reference Material 83j.

OXBU.......... Chromite, Bushveld Complex, S. Africa.

OXGH.......... Gahnite, Brazil.

OXIL........... Ilmenite, Ilmen, USSR.

OXNC.......... Synthetic bunsenite, NiO.

OXPA ........... Synthetic bixbyite, $\mathrm{Mn}_{2} \mathrm{O}_{3}$.

OXTB .......... Chromite, Tiebaghi, New Caledonia.

OXVA........... Synthetic $\mathrm{V}_{2} \mathrm{O}_{3}$.

PXEN.......... Synthetic enstatite, $\mathrm{MgSiO}_{3}$.

SPHC ......... Titanite, Hemet quadrangle, California

${ }^{1}$ Used regularly only for parsettensitelike phase and to check other silicates.
${ }^{2}$ Used to analyze phase D only.

current) and using a focused beam (estimated activation volume less than $10 \mu^{3}$ ). The standard or unknown was exposed to the electron beam for 20 to 80 seconds. Analytical software was described by McGee (1985). Mineral standards, documented by Huebner and Woodruff (1986), are summarized in table 2 . Backgrounds were obtained by interpolation, based on the mean atomic 
number $(Z)$ of the unknown, between the count rates obtained on quartz or $\mathrm{MgO}$ (low $\mathrm{Z}$ ) and on tephroite, $\mathrm{NiO}$, or $\mathrm{V}_{2} \mathrm{O}_{3}$ (high $\mathrm{Z}$ ). Peak intensity data were corrected by the method of Bence and Albee (1968). Alpha factors used for constituent oxides were measured by Albee and Ray (1970) and calculated from first principles. Carbon was not determined, but the carbonate analyses were corrected in a similar manner, providing that $\mathrm{CO}_{2}$ had been excluded from the analysis of the reference standard (and the calculation of its set of $\beta$-factors). Analyzed compositions of all phases were compared with an energy dispersive analysis spectrum to determine whether any elements present in significant quantities had been missed in the wavelength dispersive analysis.

Fluid inclusion techniques were not used in this study because fluid inclusions are rare in the Buckeye ore. The only inclusions found were in a minute amount of barite that appeared to replace rhodochrosite in sample B29. These inclusions were minute and had small vapor bubbles.

\section{REGIONAL GEOLOGY}

In lithologic variation and deformation, the thinly banded ore mimics the host Franciscan Complex but in miniature. Thus, in addition to providing a geologic framework for manganese deposition, the regional geology may provide clues to the origin of some delicate textures of the ores. The area containing the Ladd and Buckeye mines has been mapped by Huey (1948), Cox and others (in Trask and others, 1950, pl. 4), Maddock (1955), Raymond (1973a,b), and Raymond and Maddock (unpub. mapping, 1976-78). Detailed geologic descriptions of the immediate vicinity of the Buckeye mines were published by Pierce (in Trask, 1950, pl. 17) and by Volin and Matson (1949). Huebner (1967) recognized that the metagraywacke sequences at the Buckeye mine were turbidites that retained clastic texture after lowtemperature and high-pressure metamorphism. Ernst (1971) correlated the textural grade of the metagraywackes with the development of metamorphic assemblages containing pumpellyite, albite, lawsonite, and jadeitic pyroxene but did not find jadeitic pyroxene near the Buckeye. We will demonstrate below that the metagraywackes correspond to his textural grades 1 and 2 and mineral zone 2. Raymond (1973a,b) provided metamorphic and tectonostratigraphic maps. He found lawsonite and albite in the immediate vicinity of the Buckeye mine and recognized both jadeite and aragonite elsewhere in the unit that contains the Buckeye mine, but he found no relationship between metamorphic grade and texture (Raymond, written commun., Feb. 6, 1988). Huebner (1967), Hein and others (1987), and Hein and Koski (1987) provided many other relevant observations, but no maps.
The vicinities of the Buckeye and Ladd mines are each characterized by sandstones containing an unusual abundance of chert (fig. 1A), most of which is interbedded with argillaceous layers. Each area contains one large and several smaller manganese deposits. The eastern chert-rich sequence contains the large north Buckeye orebody and the smaller south Buckeye, Sulphur Gulch, Tiptop, Grummett, Grummett-Knox, Liberty, and Moran Brothers deposits, each closely associated with the chert. The western (Ladd) sequence is similar. These chert sequences pinch out and are truncated by shear zones to the west (Buckeye) and to the east (Ladd sequence). The similarities in outcrop pattern, regional strike (west-northwest), and alignment of both chert and manganese horizons might suggest that the eastern and western districts were once a continuous manganiferous horizon that was broken into distinct segments (deposits), but mapping by Raymond (1973a,b; written commun., Feb. 6, 1988) shows that the deposits lie in several lithologically distinct units.

The Buckeye mines lie in the northern side of Buckeye Gulch, in an area characterized by steep slopes, a high ratio of rhythmic chert to graywacke, and prominent outcrops (reefs) of northerly dipping massive chert (fig. $1 B$ ). Sulphur Gulch, to the north, is characterized by gentler topography and by sheared and altered graywacke with much less chert. South of the chert-rich section, near the bottom of Buckeye Gulch, are blocks or pods of glaucophane schist and carbonatized ultramafic rock in sheared graywacke, below a layer of coarse conglomerate. The south side of the gulch is graywacke with distinctly less chert than the north side. Raymond (1973a) recognized that this terrain consists of broken units and subdivided the area into three broken formations, which we here use informally: the graywacke-rich Sulphur Gulch, the chert-rich Grummett, and the southerly Oso broken formations (KJfsg, KJfg, and KJfo, respectively, in fig. $1 B$ ). We have informally adopted Raymond's subdivision because it is useful in describing the graywacke-rich and chert-rich units in the vicinity of the Buckeye deposits. The Grummett broken formation contains the Buckeye mines and consists of the first $800-900 \mathrm{~m}$ of the Buckeye stratigraphic section by Hein and Koski (1987, p. 723), from the conglomerate at the base to approximately the greenstone. Glaucophane schist, greenstone, and carbonate-rich blocks are either erosional remnants of an overthrust unit or slivers of basement brought up along faults bounding the Grummett broken formation. In either case, the composition and metamorphism of these blocks do not relate directly to the history of the area.

To describe the degree to which the bedding of the graywackes, chert, and manganiferous sediments was disrupted, we adopted the classification of Raymond 
(1984, his fig. 1, classification type VIII). In this scheme there is a progression from coherent (well-stratified) units through broken units (in which the fragments are moved slightly relative to each other) and dismembered units (in which there is no suggestion of the initial relative positions) to a melange (in which disoriented fragments are engulfed in a matrix). We understand that there is no consensus on the terminology used to describe complexes and melanges; for instance, the classification of Cowan (1985) places more emphasis on lithologic types. We chose the scheme of Raymond because we found it useful in describing the disruption of unusual manganese-rich lithologies.

Near the Buckeye mine, the degree of stratigraphic continuity decreases with decreasing scale of the domain considered. Raymond (1973a) mapped the regional units as broken formations. Within the Grummett broken formation, the chert bodies have irregular shapes in outcrop pattern (see Trask, 1950, pls. 4, 17) that suggest intricate folding; the chert appears to float in sandstone yet retains a strike and dip that is predominantly parallel to the regional trend. One of us (Huebner) had difficulty following sedimentary contacts on a scale exceeding several hundreds of meters because the chert reefs consist of slightly displaced blocks (called phacoids by Raymond, 1973a, 1977). At the scale of the chert reefs, the structure is transitional between that of the broken and disrupted units. We will show that much of the ore, on the scale of a hand specimen and thin section, is a breccia with cataclastic to mylonitic textures. This intensely disrupted material may represent the massive ores described by some of our predecessors. Nevertheless, layered and laminated ore, intact on at least the scale of a hand specimen, does occur. Some breccia fragments in the disrupted ore are layered and laminated, evidence that they were once part of a welllayered sediment.

Despite disruption of the stratigraphic section, the nonmanganiferous host rocks provide important clues to the sources of sediment, the nature of the depositional environment, and the subsequent metamorphism. Most of the sediments are either detritus from a continent or a magmatic arc or skeletal debris from marine pelagic organisms. Deposition of each type was predominantly by turbidity flows. Metamorphism was at very high pressures and low temperatures, implying rapid subsidence and uplift.

\section{REGIONAL LITHOLOGIES}

Coarse conglomerate occurs at the base of the exposed Grummett broken formation in the western part of Buckeye Gulch. Rounded cobbles of black and green chert, white vein quartz, feldspar porphyry with green matrix, and shale form clasts that are suspended in a matrix of greenish graywacke. This conglomerate is probably from the same provenance as the matrix of the massive graywacke elsewhere in the Grummett unit and may incorporate earlier Franciscan sediments.

The turbidite units are dominantly massive graywacke and include minor laminated siltstone, shale, and intraformational conglomerates in which shale chips are suspended in greenish-gray to gray graywacke matrix. Graded beds are rare; one unusually complete unit grades from conglomerate to shale (Huebner, 1967, p. 28) and indicates that, locally at least, the north-dipping beds are not overturned. Ten representative graywackes from the Grummett broken formation and its contact zones were examined in thin section (table 3 ) and by XPD (table 4). All graywackes retain clastic texture. The framework consists of albite, quartz, chert, microporphyries, shale and clay chips (some black and of moderately high reflectivity, presumably due to organic matter), biotite, muscovite, reddish chromite, and zircon, in decreasing order of abundance. Most quartz clasts are monocrystalline and unstrained. Quartz clasts that are polycrystalline or that do not extinguish uniformly under crossed nicols are uncommon. The compositions of some detrital minerals are summarized in table 5. Pyroclastic components, if present, have been transported and reworked by sedimentary processes. Postdepositional processes included compaction of the matrix, corrosion of framework grains, and incipient recrystallization, corresponding to the textural grades 1 and 2 of Ernst (1971). The fabric varies from essentially unfoliated to slightly foliated in hand specimen (distinctly foliated in thin section). Of the metamorphic minerals, lawsonite is ubiquitous and develops in framework albite and in the matrix. Other metamorphic minerals are concentrated in the matrix. Chlorite (IIb structural type of Bailey, 1980), phengitic muscovite, and titanite occur in every section. Calcite and chloritized biotite occur in most sections; brown stilpnomelane appears in several thin sections and in one thin section was confirmed by microprobe chemical analysis (table 5). Glaucophane, clinopyroxene, and palegreen $\mathrm{TiO}_{2}$ (anatase) are uncommon, and green tourmaline is rare. Jadeite, laumontite, pumpellyite, and clinoptilolite were sought but never identified in our samples. Aragonite occurs in white veins in sheared or altered graywacke and greenstone, which occur near the contacts between the broken formations, but, in contrast, coarsely crystallized (primary) calcite with rhombohedral cleavage is the characteristic polymorph in graywacke of the interior of the broken units. With the exception of the albite-lawsonite association, petrographic criteria for an equilibrium assemblage are lacking. Representative chemical analyses of metamorphic minerals are given in table 5 . These minerals should be 
TABLE 3.-Constituents of graywackes from the Buckeye deposit, California Coast Ranges [Modes of clasts are visual estimates only, obtained from thin sections. tr, trace; $x$, present; -, not observed]

\begin{tabular}{|c|c|c|c|c|c|c|c|c|c|c|}
\hline Sample & B44 & $\mathrm{B} 110$ & $65 \mathrm{H} 10$ & $65 \mathrm{H} 27$ & $65 \mathrm{H} 35$ & $65 \mathrm{H} 72$ & $65 \mathrm{H} 73$ & $65 \mathrm{H} 74$ & $65 \mathrm{H} 110$ & $65 \mathrm{H} 119$ \\
\hline \multicolumn{11}{|c|}{ Modes of clasts, in volume percent } \\
\hline Quartz.................... & 60 & 50 & 55 & 50 & 40 & 35 & 35 & 50 & 45 & 55 \\
\hline Chert. $\ldots \ldots, \ldots, \ldots, \ldots, \ldots \ldots$ & 5 & 10 & 10 & 10 & 20 & 30 & 15 & 10 & 20 & 5 \\
\hline Plagioclase ............... & 20 & 25 & 20 & 20 & 25 & 20 & 25 & 20 & 25 & 20 \\
\hline Lithic fragments............ & $<5$ & $<5$ & $<5$ & $<5$ & $<5$ & $<5$ & $<5$ & $\operatorname{tr}$ & $<5$ & $\operatorname{tr}$ \\
\hline Groundmass............... & 15 & 15 & 15 & 20 & 15 & 15 & 20 & 20 & 10 & 20 \\
\hline \multicolumn{11}{|c|}{ Mineralogy } \\
\hline Quartz.................... & $\mathrm{x}$ & $\mathrm{x}$ & $\mathrm{x}$ & $\mathrm{x}$ & $\mathrm{x}$ & $\mathrm{x}$ & $\mathrm{x}$ & $\mathrm{x}$ & $\mathrm{x}$ & $\mathrm{x}$ \\
\hline Albite $\ldots \ldots \ldots \ldots \ldots \ldots \ldots$ & $\mathbf{x}$ & $\mathbf{x}$ & $\mathbf{x}$ & $\mathbf{x}$ & $\mathbf{x}$ & $\mathrm{x}$ & $\mathrm{x}$ & $\mathbf{x}$ & $\mathrm{x}$ & $\mathrm{x}$ \\
\hline Lawsonite.................. & $\mathbf{x}$ & $\mathrm{x}$ & $\mathbf{x}$ & $\mathbf{x}$ & $\mathbf{x}$ & $\mathbf{x}$ & $\mathrm{x}$ & $\mathbf{x}$ & $\mathbf{x}$ & - \\
\hline Glaucophane................ & $\mathbf{x}$ & - & $\mathrm{x}$ & - & - & - & $\mathrm{x}$ & - & $\mathbf{x}$ & - \\
\hline Ca-carbonate $\ldots \ldots \ldots \ldots \ldots \ldots$ & $\mathrm{x}$ & $\mathrm{x}$ & $\mathrm{x}$ & $\mathrm{x}$ & $\mathrm{x}$ & - & $\mathrm{x}$ & - & $\mathbf{x}$ & - \\
\hline Biotite (chloritized) $\ldots \ldots \ldots \ldots \ldots$ & $\mathbf{x}$ & $\mathbf{x}$ & $\mathrm{x}$ & $\mathbf{x}$ & $\mathrm{x}$ & $\mathrm{x}$ & $\mathrm{x}$ & $\mathbf{x}$ & $\mathrm{x}$ & $\mathrm{x}$ \\
\hline Chlorite $\ldots \ldots \ldots \ldots \ldots \ldots \ldots \ldots$ & $\mathbf{x}$ & $\mathrm{x}$ & $\mathbf{x}$ & $\mathbf{x}$ & $\mathbf{x}$ & $\mathbf{x}$ & $\mathrm{x}$ & $\mathbf{x}$ & $\mathbf{x}$ & $\mathrm{x}$ \\
\hline Muscovite.................. & $\mathbf{x}$ & $\mathrm{x}$ & $\mathbf{x}$ & $\mathrm{x}$ & $\mathbf{x}$ & $\mathrm{x}$ & $\mathrm{x}$ & $\mathbf{x}$ & $\mathbf{x}$ & $\mathrm{x}$ \\
\hline Stilpnomelane .............. & $\mathbf{x}$ & - & - & - & - & - & - & - & - & - \\
\hline Spinel-chromite............. & $\mathbf{x}$ & $\mathrm{x}$ & - & $\mathrm{x}$ & $\mathrm{x}$ & $\mathrm{x}$ & $\mathrm{x}$ & - & - & - \\
\hline Titanite $\ldots \ldots \ldots \ldots \ldots \ldots \ldots \ldots$ & $\mathbf{x}$ & - & $\mathbf{x}$ & - & - & $\mathbf{x}$ & $\mathrm{x}$ & - & $\mathbf{x}$ & $\mathrm{x}$ \\
\hline Anatase...$\ldots \ldots \ldots \ldots \ldots$ & $\mathbf{x}$ & $\mathrm{x}$ & - & $\mathbf{x}$ & $\mathbf{x}$ & - & - & $\mathbf{x}$ & - & $\mathbf{x}$ \\
\hline Zircon $\ldots \ldots \ldots \ldots \ldots \ldots \ldots$ & $\mathrm{x}$ & $\mathrm{x}$ & $\mathbf{x}$ & - & $\mathrm{x}$ & $\mathrm{x}$ & $\mathrm{x}$ & $\mathbf{x}$ & - & - \\
\hline Tourmaline................. & - & $\mathrm{x}$ & - & $\mathrm{x}$ & - & - & - & $\mathbf{x}$ & - & - \\
\hline Clinopyroxene.............. & $\mathbf{x}$ & - & - & - & $\mathbf{x}$ & - & - & - & - & - \\
\hline Fe-oxide or hydroxide.......... & $\mathbf{x}$ & - & $\mathbf{x}$ & $\mathbf{x}$ & - & $\mathrm{x}$ & $\mathbf{x}$ & $\mathbf{x}$ & $\mathbf{x}$ & $\mathbf{x}$ \\
\hline Green claylike material $^{1} \ldots \ldots \ldots$ & $\mathbf{x}$ & $\mathrm{x}$ & $\mathbf{x}$ & $\mathbf{x}$ & - & $\mathrm{x}$ & - & - & $\mathbf{x}$ & - \\
\hline
\end{tabular}

${ }^{1}$ Present in very sparse amounts.

regarded as index minerals rather than as metamorphic assemblages. The critical associations are quartz + albite + lawsonite + calcite + chlorite and quartz + albite + lawsonite + aragonite + chlorite.

The mineralogy of the framework elements and the bulk chemistry of the graywackes from the Grummett broken formation and close to the Buckeye deposit are potential indicators of sediment source and depositional environment. Some discriminants, reviewed by Taylor and McLennan (1985), include analyses of modern sands (Maynard and others, 1982) and Phanerozoic sandstones (Dickinson and others, 1983). Interpretation of the Buckeye graywackes is ambiguous. The high proportion of quartz clasts (table 3) suggests derivation from a continental block or uplifted orogenic zone; without knowledge of the original lithic clast population, which may have been altered during diagenesis or metamorphism, we cannot distinguish between these two environments. The small value of $\mathrm{K}_{2} \mathrm{O} / \mathrm{Na}_{2} \mathrm{O}$ (table 6) suggests an island-are setting. However, the apparent island-arc signature may merely reflect loss of $\mathrm{K}_{2} \mathrm{O}$ due to metasomatism. The range of rare-earth-element patterns for seven Buckeye graywackes (see fig. $7 A$; average values in table 6; Huebner and Flohr, unpub. data) are similar to patterns for the quartz-intermediate graywackes of Taylor and McLennan (1985). This group includes recycled orogens, continental blocks, and dissected magmatic arcs but excludes a forearc basin deriving sediment from a young andesitic arc. We favor a sediment source such as a deeply dissected continental magmatic arc complex, augmented by intraformational clasts of shale and chert derived from near the site of deposition. In studying graywackes from throughout the Franciscan Complex, Dickinson and others (1982) observed a smaller proportion of monocrystalline quartz clasts and tentatively concluded that potassium feldspar was originally present but has been replaced by albite. They concluded that the Franciscan graywackes of the Diablo Range were derived from the southern portion of the SierranKlamath magmatic arc, near the Mojave block. Seiders and Blome (1988) examined conglomerates in the Franciscan Complex of the Diablo Range. They concluded that conglomerates rich in volcanic clasts were transported directly westward and that chert-rich conglomerates were transported southward. However, they did not report data for the conglomerates shown in figure $1 B$.

The contacts between the graywacke units and the thick sequences of interbedded chert and metashale, although not well exposed, were originally thought by Huebner (1967) to be sedimentary. Raymond (1974) suggested that, at least locally, some contacts between chert and graywacke are sedimentary, yet Raymond (1973a; written commun., 1988) stated that most of the intraformational contacts between chert and graywacke are now sheared as a consequence of postdepositional 
TABLE 4.-Characterization of metasandstones, metacarbonates, and metavolcanic rocks from the Buckeye deposit, California Coast Ranges, by $X$-ray powder diffractometry

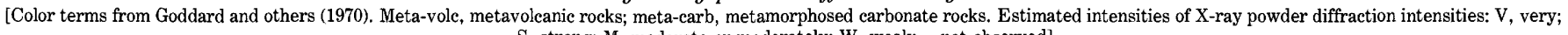
$\mathrm{S}$, strong; M, moderate or moderately; W, weak; -, not observed]

\begin{tabular}{|c|c|c|c|c|c|c|c|}
\hline $\begin{array}{l}\text { Sample } \\
\text { Color } \\
\text { Foliation } \\
\text { Rock type }\end{array}$ & $\begin{array}{c}\text { B44 } \\
\text { Greenish gray } \\
\text { None } \\
\text { Graywacke }\end{array}$ & $\begin{array}{c}\text { B110 } \\
\text { Light olive gray } \\
\text { None } \\
\text { Graywacke }\end{array}$ & $\begin{array}{c}65 \mathrm{H} 18 \\
\text { Light olive gray } \\
\text { Weak } \\
\text { Graywacke }\end{array}$ & $\begin{array}{c}65 \mathrm{H} 20 \\
\text { Light olive gray } \\
\text { None } \\
\text { Meta-volc }\end{array}$ & $\begin{array}{c}65 \mathrm{H} 27 \\
\text { Light olive gray } \\
\text { None } \\
\text { Graywacke }\end{array}$ & $\begin{array}{c}65 \mathrm{H} 28 \\
\text { Light olive gray } \\
\text { None } \\
\text { Graywacke }\end{array}$ & $\begin{array}{l}65 \mathrm{H} 28 \\
\text { White } \\
\text { None } \\
\text { Vein }\end{array}$ \\
\hline Quartz ........... & VS & VS & $\mathrm{M}$ & $\mathrm{S}$ & VS & $\mathrm{S}$ & VW \\
\hline Low albite ........ & $\mathrm{S}$ & VS & $\mathrm{M}$ & VS & $\mathrm{S}$ & $\mathrm{S}$ & - \\
\hline Chlorite ......... & VW & VW & $\mathrm{M}$ & $\mathbf{M}$ & MS & M & - \\
\hline Muscovite ....... & VW & VVW & W & - & - & - & - \\
\hline Calcite .......... & - & W & - & M & VW & - & W \\
\hline Aragonite......... & - & - & - & - & - & - & $\mathrm{M}$ \\
\hline Lawsonite . . . . . . . & - & - & - & - & - & W & - \\
\hline Sample & $65 \mathrm{H} 29$ & $65 \mathrm{H} 29$ & $65 \mathrm{H} 29 \mathrm{~B}$ & $65 \mathrm{H} 30 \mathrm{~A}$ & $65 \mathrm{H} 30 \mathrm{~B}$ & $65 \mathrm{H} 30 \mathrm{C}$ & $65 \mathrm{H} 31^{1}$ \\
\hline Color & Grayish olive & Very light gray & Olive gray & White & Light gray & Olive gray & Mottled gray brown \\
\hline Foliation & None & None & None & None & Laminated & Laminated & Weak \\
\hline Rock type & Greenstone & Vein & Greenstone & Vein & Meta-carb & Meta-carb & Meta-carb \\
\hline Quartz .......... & MW & VVW & M & M & $\mathrm{S}$ & VS & MS \\
\hline Low albite........ & - & - & W & - & - & - & - \\
\hline Chlorite ......... & $\mathrm{S}$ & - & MS & - & VVW & VW & - \\
\hline Muscovite ....... & - & - & - & - & - & - & - \\
\hline Calcite ......... & VW & M & - & M & VVW & MS & MW \\
\hline Aragonite......... & W & W & - & M & W & $\mathbf{M}$ & MW \\
\hline Lawsonite . . . . . . . & - & - & VW & - & - & - & - \\
\hline Dolomite...$\ldots \ldots$ & - & - & - & - & VS & $\mathrm{S}$ & - \\
\hline Sample & $65 \mathrm{H} 33$ & $65 \mathrm{H} 33$ & $65 \mathrm{H} 34$ & $65 \mathrm{H} 35$ & $65 \mathrm{H} 43$ & $65 \mathrm{H} 43$ & $65 \mathrm{H} 51$ \\
\hline Color & Medium dark gray & White & Light olive gray & Light olive gray & Dark gray & White & Pale yellowish brown \\
\hline Foliation & Slight & None & Slight & Slight & None & None & None \\
\hline Rock type & Greenstone & Vein & Graywacke & Graywacke & Hornfels & Vein & Hornfels \\
\hline Quartz .......... & VS & $\mathrm{S}$ & $\mathrm{S}$ & VS & $\mathrm{S}$ & W & $\mathrm{M}$ \\
\hline Low albite ........ & MW & - & VS & VVS & - & - & - \\
\hline Chlorite ......... & MW & - & M & VW & MW & - & M \\
\hline Muscovite ........ & - & - & $\mathrm{VW} ?$ & VVW? & W & - & - \\
\hline Calcite .......... & - & VVW & - & - & - & W & W \\
\hline Aragonite. . . . . . . & - & W & - & - & - & MS & M \\
\hline Lawsonite . . . . . . . & W & - & VW & - & W & - & VW \\
\hline Glaucophane ...... & - & - & - & - & MW & - & - \\
\hline Sample & $65 \mathrm{H} 52$ & $65 \mathrm{H} 55$ & $65 \mathrm{H} 55$ & $65 \mathrm{H} 56$ & $65 \mathrm{H} 57$ & $65 \mathrm{H} 59$ & $65 \mathrm{H} 60$ \\
\hline Color & Light olive gray & Light olive gray & White & Light olive gray & Light olive gray & Olive gray & Dark gray \\
\hline Foliation & None & Slight & None & None & Slight & None & None \\
\hline Rock type & Greenstone & Graywacke & Vein & Meta-carb & Graywacke & Meta-volc & Hornfels \\
\hline Quartz .......... & M & MS & W & M & $\mathrm{S}$ & MS & $\mathrm{S}$ \\
\hline Low albite ......... & $\mathrm{S}$ & $\mathbf{M}$ & - & - & $\mathrm{S}$ & $\mathrm{M}$ & - \\
\hline Chlorite .......... & M & W & - & $\mathrm{M}$ & W & MS & W \\
\hline Muscovite ........ & - & - & - & - & - & - & - \\
\hline Calcite ......... & - & - & $\mathrm{S}$ & - & - & - & VVS \\
\hline Aragonite. . . . . . . . & W & - & VVW & MW & - & - & VW \\
\hline Lawsonite . . . . . . & - & - & - & W & - & - & - \\
\hline Sample & $65 \mathrm{H} 65$ & $65 \mathrm{H} 72$ & $65 \mathrm{H} 73$ & $65 \mathrm{H} 74$ & & & \\
\hline Color & Light olive gray & Medium gray & Medium gray & Greenish gray & & & \\
\hline Foliation & Slight & None & None & Slight & & & \\
\hline Rock type & Graywacke & Graywacke & Graywacke & Graywacke & & & \\
\hline Quartz .......... & VS & VVS & VVS & VS & & & \\
\hline Low albite ......... & VS & W & VS & $\mathrm{S}$ & & & \\
\hline Chlorite ......... & $\mathrm{M}$ & VVW & $\mathrm{M}$ & M & & & \\
\hline Muscovite ........ & - & - & - & W & & & \\
\hline Calcite .......... & - & - & VVW & - & & & \\
\hline Aragonite. ........ & - & - & - & - & & & \\
\hline Lawsonite . . . . . . & - & - & W & - & & & \\
\hline
\end{tabular}

${ }^{1} \mathrm{XPD}$ patterns from $65 \mathrm{H} 31$ also contain a weak reflection at $2.894 \AA$. 
TABLE 5.-Compositions of minerals from nonsiliceous host rock, in weight percent, from the Buckeye deposit, California Coast Ranges, determined by electron microprobe analysis

[Total $\mathrm{Fe}$ reported as $\mathrm{FeO}$ for all minerals. Ferrous and ferric iron calculated assuming ideal stoichiometry of 3 cations per 4 oxygens for chromites. Analyses used are average of 3 points for all minerals except chlorite in sample 65H73; nd, not detected; na, not analyzed. $\mathrm{H}_{2} \mathrm{O}$ was not analyzed, resulting in low oxide sums for tourmaline, muscovite, glaucophane, stilpnomelane, lawsonite, chlorite, and possibly titanite; $\mathrm{CO}_{2}$ was not analyzed, resulting in low oxide sums for carbonate minerals]

\begin{tabular}{|c|c|c|c|c|c|c|c|c|}
\hline \multicolumn{9}{|c|}{ Detrital minerals } \\
\hline \multirow[b]{2}{*}{ Sample } & \multirow{2}{*}{$\frac{\text { Titanite }^{1}}{65 \mathrm{H} 73}$} & \multirow{2}{*}{$\frac{\text { Augite }^{2}}{\text { B44 }}$} & \multicolumn{4}{|c|}{ Chromite $^{3}$} & \multirow{2}{*}{$\frac{\text { Tourmaline }}{65 \mathrm{H} 27}$} & \multirow{2}{*}{$\frac{\text { Muscovite }}{65 \mathrm{H} 74}$} \\
\hline & & & $65 \mathrm{H} 73$ & B110 & $65 \mathrm{H} 30$ & $65 \mathrm{H} 31$ & & \\
\hline $\mathrm{SiO}_{2} \ldots \ldots$ & .. 29.6 & 50.9 & 0.03 & 0.05 & nd & nd & 36.3 & 50.5 \\
\hline $\mathrm{Al}_{2} \mathrm{O}_{3} \ldots \ldots$ & . 1.09 & 4.28 & 35.4 & 9.86 & 2.94 & 8.30 & 31.7 & 28.8 \\
\hline $\mathrm{TiO}_{2} \ldots \ldots$ &. .36 .1 & .43 & .05 & .22 & nd & nd & .29 & .28 \\
\hline $\mathrm{V}_{2} \mathrm{O}_{3}, \ldots$ &.$\quad .50$ & .05 & .20 & .24 & .21 & .21 & .15 & nd \\
\hline $\mathrm{Cr}_{2} \mathrm{O}_{3} \ldots$ & .. na & .24 & 32.6 & 51.9 & 61.1 & 59.2 & .03 & na \\
\hline $\mathrm{FeO} \ldots \ldots$ & .. 1.24 & 5.81 & 17.1 & 33.4 & 28.6 & 23.5 & 6.73 & 3.15 \\
\hline $\mathrm{MnO} . . .$. & . $\quad .17$ & .12 & .24 & .57 & .52 & .41 & .09 & nd \\
\hline $\mathrm{MgO} . . .$. & .. $\quad .10$ & 15.4 & 14.6 & 2.33 & 5.38 & 7.43 & 8.05 & 2.50 \\
\hline $\mathrm{ZnO} \ldots \ldots$ & .. nd & na & na & na & .18 & .16 & na & nd \\
\hline $\mathrm{NiO} \ldots . .$. & . . nd & nd & .10 & nd & nd & .05 & nd & nd \\
\hline $\mathrm{CaO} \ldots \ldots$ & . . 28.2 & 21.9 & nd & nd & .12 & .13 & 1.34 & .05 \\
\hline $\mathrm{BaO} \ldots \ldots$ & .. nd & nd & na & na & na & na & na & .23 \\
\hline $\mathrm{Na}_{2} \mathrm{O} \ldots \ldots$ & .03 & .29 & nd & nd & nd & nd & 1.81 & .13 \\
\hline $\mathrm{K}_{2} \overline{\mathrm{O}} \ldots \ldots$ & na & nd & na & na & na & na & nd & 9.25 \\
\hline Sum ... & .997 .03 & 99.42 & 100.32 & 98.57 & 99.05 & 99.39 & 86.49 & 94.89 \\
\hline $\mathrm{FeO} \ldots \ldots$ & - & - & 15.1 & 29.1 & 23.1 & 20.8 & - & - \\
\hline $\mathrm{Fe}_{2} \mathrm{O}_{3} \ldots \ldots$ & - & - & 2.24 & 4.81 & 6.13 & 2.93 & - & - \\
\hline
\end{tabular}

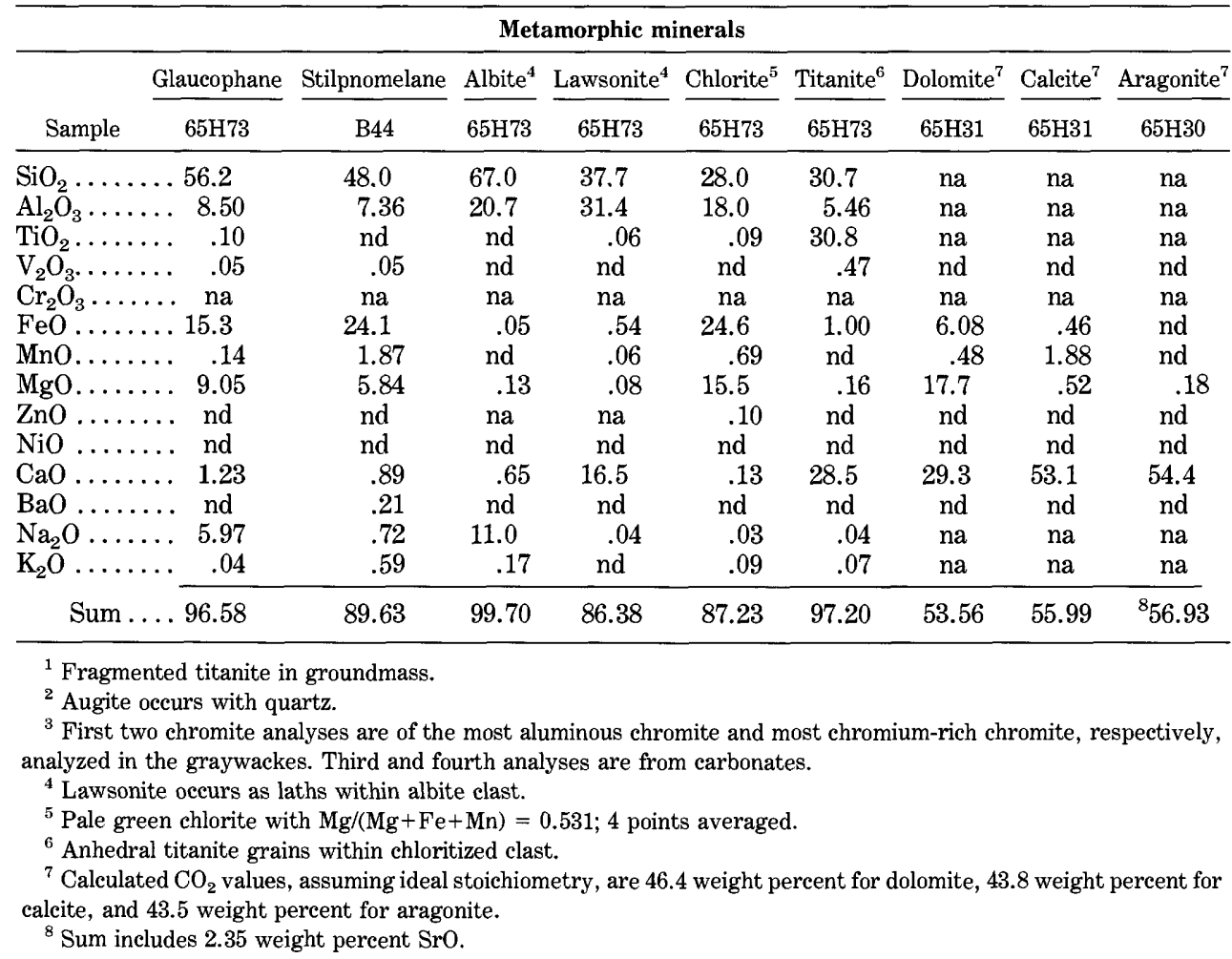

soft-sediment and tectonic deformation. Hein and Karl (1983, p. 35-36) and Hein and others (1987, p. 210) also thought that the contacts were sedimentary. Hein and Koski (1987, p. 725) noted "gradational sedimentary contacts between the underlying sandstone and the radiolarian chert-argillite sections." Subsequently they reported that "the field relations clearly show depositional contacts between the graywacke sandstones and the rhythmically bedded chert-argillite sections" (Hein and Koski, 1988, p. 470). However, the undulatory and lenslike outcrop pattern (figs. $1 A, B$ ) of slivers of chert in graywacke may be the result of soft-sediment foundering 
TABLE 6. - Chemistry and mineralogy of selected protoliths from the Buckeye deposit, California Coast Ranges [Chert, average of 35 cherts from the Ladd-Buckeye district (Hein and others, 1987); analyses by XRF, ICP, and INAA methods; metashale, average of 7 metashale samples, LaddBuckeye district (Hein and others, 1987); graywacke, average of 7 graywacke samples (B44, B110,65H27,65H35, 65H72,65H73,65H74), Buckeye district; modes for these samples are given in table 3. W237-, sample number prefix assigned by Sample Control, Branch of Geochemistry, USGS. ICP (inductively coupled plasma atomic emission spectrometry) by $\mathrm{H}$. Kirschenbaum; INAA (instrumental neutron activation analysis) by J.N. Grossman; FAAS (flame atomic absorption spectrometry) by $\mathrm{H}$. Kirschenbaum; SQES (semiquantitative DC-arc emission spectroscopy) by Janet Fletcher; XRF-EDA (X-ray fluorescence with energy dispersive analysis) by R.G. Johnson; GAAS (graphite-furnace atomic absorption spectrometry) by M.W. Doughten; Sep (extraction preceded analysis) by M.W. Doughten, B. Libby, and P.J. Aruscavage; Coul., coulometric determination; Pen., modified Penfield method; Grav., gravimetric determination; pct, percent; ppm, parts per million; ppb, parts per billion; -, chemistry not reported or not available or mineral not observed in Buckeye samples. Mineral mode not reported for chert and metashale. All Buckeye samples have less than $2 \mathrm{ppm} R$ b by XRF and less than $2 \mathrm{ppm}$ Se by INAA. Estimate of mineral modes from visual examination of $\mathrm{X}$-ray powder diffraction patterns]

\begin{tabular}{|c|c|c|c|c|c|c|c|c|c|c|}
\hline $\begin{array}{l}\text { Sample } \\
\text { W237- }\end{array}$ & $\begin{array}{l}\text { B50 } \\
507\end{array}$ & $\begin{array}{l}B 64 \\
503\end{array}$ & $\begin{array}{c}\text { B112 } \\
506\end{array}$ & $\begin{array}{l}\text { B84 } \\
505\end{array}$ & $\begin{array}{l}\text { B95 } \\
511\end{array}$ & $\begin{array}{l}\text { B104 } \\
510\end{array}$ & $\begin{array}{c}65 \mathrm{H} 79 \\
509\end{array}$ & Chert & Metashale & Graywacke \\
\hline $\mathrm{SiO}_{2}, \ldots \ldots \ldots$ pet $\ldots \ldots \ldots$ ICP $\ldots \ldots \ldots$. & 9.4 & 38.7 & 17.0 & 33.2 & 16.1 & 8.3 & 22.6 & 94.39 & 58.13 & 67.9 \\
\hline $\mathrm{Al}_{2} \mathrm{O}_{3} \ldots \ldots \ldots$ pet $\ldots \ldots \ldots$ ICP $\ldots \ldots \ldots$ & .40 & .21 & 2.14 & 3.25 & 1.25 & .070 & .047 & 1.71 & 16.0 & 12.8 \\
\hline $\mathrm{Fe}_{2} \mathrm{O}_{3}{ }^{1} \ldots \ldots$ pet $\ldots \ldots \ldots$ INAA $\ldots \ldots$ & .187 & .164 & 1.47 & 2.15 & .892 & .189 & .095 & 1.208 & 8.58 & 5.3 \\
\hline $\mathrm{MgO} \ldots \ldots \ldots$ pet $\ldots \ldots \ldots$ ICP $\ldots \ldots \ldots$ & 1.2 & .94 & 3.83 & 9.28 & 2.55 & .66 & 2.28 & .59 & 3.21 & 2.5 \\
\hline MnO .........pet ........ICP $\ldots \ldots \ldots$ & 60.4 & 31.9 & 47.6 & 35.8 & 64.9 & 79.5 & 63.4 & .21 & .27 & .22 \\
\hline $\mathrm{CaO} \ldots \ldots \ldots$ pet $\ldots \ldots \ldots$ ICP $\ldots \ldots \ldots$ & .32 & 4.27 & 1.68 & 1.04 & .18 & .12 & .04 & .12 & .89 & 1.6 \\
\hline $\mathrm{Na}_{2} \mathrm{O} \ldots \ldots \ldots$ pet $\ldots \ldots \ldots$ INAA $\ldots \ldots$. & .008 & .015 & .058 & .023 & .015 & .007 & .009 & .28 & 1.52 & 4.4 \\
\hline $\mathrm{K}_{2} \mathrm{O} \ldots \ldots \ldots$ pet $\ldots \ldots \ldots$ FAAS ...... & $<.1$ & $<.1$ & $<.1$ & $<.1$ & $<.1$ & $<.1$ & $<.1$ & .34 & 4.08 & 1.0 \\
\hline $\mathrm{CO}_{2} \ldots \ldots \ldots$ pet $\ldots \ldots \ldots$ Coul $\ldots \ldots \ldots$ & 23.6 & 23.0 & 19.8 & 3.09 & 5.06 & 4.69 & .66 & - & - & .25 \\
\hline $\mathrm{H}_{2} \mathrm{O}+\ldots \ldots \ldots$ pct $\ldots \ldots \ldots$. Pen. ...... & 3.2 & .3 & 4.6 & 9.0 & 3.7 & 2.7 & 7.5 & ${ }^{2} .72$ & ${ }^{2} 6.0$ & 3.3 \\
\hline $\mathrm{H}_{2} \mathrm{O}-\ldots \ldots \ldots$ pet $\ldots \ldots \ldots$ Grav. ...... & .1 & .1 & .9 & 1.8 & .1 & .1 & .4 & - & - & - \\
\hline $\mathrm{P}_{2} \mathrm{O}_{5} \ldots \ldots \ldots \ldots$ pet $\ldots \ldots \ldots$ ICP $\ldots \ldots \ldots$ & $<.06$ & $<.06$ & .12 & .37 & $<.06$ & $<.06$ & $<.06$ & .05 & .35 & .09 \\
\hline Ti $\ldots \ldots \ldots \ldots$. ppm $\ldots \ldots \ldots$ ICP $\ldots \ldots \ldots$ & 93 & 81 & 370 & 970 & 390 & 72 & 63 & 419 & 5215 & 3342 \\
\hline V $\ldots \ldots \ldots \ldots$ ppm $\ldots \ldots \ldots$ ICP $\ldots \ldots \ldots$ & 91 & $<5$ & 1200 & 480 & 470 & 460 & 140 & 20.4 & 128.3 & 127 \\
\hline Co $\ldots \ldots \ldots \ldots$ ppm ....... INAA $\ldots \ldots$. & 6.61 & 1.72 & 22.1 & 13.1 & 26.2 & 8.8 & 5.26 & 8.0 & 27.8 & 16.6 \\
\hline $\mathrm{Ni} . \ldots \ldots \ldots \ldots$ ppm $\ldots \ldots \ldots$ ICP $\ldots \ldots \ldots$ & 170 & 79 & 350 & 150 & 840 & 650 & 740 & 22.4 & 105 & 53 \\
\hline $\mathrm{Cu} \ldots \ldots \ldots \ldots$ ppm $\ldots \ldots \ldots$ ICP $\ldots \ldots \ldots$ & $<5$ & 11 & 110 & 64 & 59 & 8 & $<5$ & 44 & 130 & 21 \\
\hline $\mathrm{Zn} \ldots \ldots \ldots \ldots$ ppm $\ldots \ldots \ldots$ FAAS $\ldots \ldots$ & 530 & 110 & 320 & 220 & 1300 & 2700 & 630 & 24.8 & 105.4 & 92 \\
\hline W.................. & 40 & $<1$ & $<1$ & 1.7 & 22 & 30 & 89 & - & - & $<1$ \\
\hline Th $\ldots \ldots \ldots \ldots$ ppm ........ INAA ...... & .214 & .18 & .97 & 2.26 & 1.48 & .180 & .073 & - & - & 6.04 \\
\hline $\mathrm{U} \ldots \ldots \ldots \ldots$ ppm $\ldots \ldots \ldots$ INAA $\ldots \ldots$ & .55 & $<.3$ & 1.23 & .59 & .84 & 1.07 & 1.05 & - & - & 1.84 \\
\hline Te..........ppm.......Sep, GAAS . & .03 & $<.02$ & .13 & .13 & .14 & $<.02$ & $<.02$ & - & - & - \\
\hline Cr..........ppm ......GAAS. . & $<2.0$ & 14 & 7.0 & 16 & 12 & 2.3 & 7.5 & 10.6 & 89.4 & 170 \\
\hline As $\ldots \ldots \ldots \ldots$ ppm .......FAAS ..... & 94 & 5.0 & 63 & 110 & 120 & 190 & 210 & - & - & 10 \\
\hline Cd ...........ppm ........Sep, GAAS . & 1.5 & .56 & 1.5 & .43 & .64 & 1.5 & 3.6 & - & - & - \\
\hline Sb. ..........ppm ........ INAA ...... & 12.0 & .122 & 1.62 & 14.0 & 6.01 & 22.6 & 24.1 & - & - & 1.31 \\
\hline Mo ..........ppm ....... Sep, ICP ... & 36 & 1.2 & 4.0 & 740 & 3.5 & 73 & 29 & - & - & $<2$ \\
\hline Be .........ppm ........Sep, GAAS . & $<.2$ & $<.2$ & .28 & .52 & .43 & .25 & .78 & - & - & .96 \\
\hline B $\ldots \ldots \ldots \ldots$ ppm $\ldots \ldots \ldots$ SQES $\ldots \ldots \ldots$ & 71 & $<3.2$ & 230 & 580 & 390 & 100 & 74 & - & - & - \\
\hline Li .................. Sepm, FAAS . & $<5.0$ & 12 & 12 & 42 & 12 & $<5.0$ & $<5.0$ & 12.9 & 36.3 & 42 \\
\hline Sc..........ppm ....... INAA $\ldots \ldots$. & .995 & .419 & 2.45 & 5.51 & 4.20 & 1.547 & 1.06 & - & - & 14.9 \\
\hline $\mathrm{Sr} \ldots \ldots \ldots \ldots$ ppm $\ldots \ldots \ldots$ ICP $\ldots \ldots \ldots$ & $<2.5$ & 120 & 33 & 27 & 3.0 & $<2.5$ & $<2.5$ & - & - & 156 \\
\hline $\mathrm{Ba} \ldots \ldots \ldots \ldots$ ppm ...... XRF-EDA... & 21 & 5200 & 70 & 400 & 74 & $<5$ & $<5$ & 214 & 870 & 337 \\
\hline Zr. .........ppm .......XRF-EDA... & $<5$ & $<5$ & $<5$ & 50 & 33 & 25 & $<5$ & - & - & 137 \\
\hline Hf. .........ppb.......INAA ..... & 106 & 450 & 331 & 830 & 490 & 177 & $<200$ & - & - & 3420 \\
\hline $\mathrm{Nb}, \ldots \ldots \ldots$. ppm $\ldots \ldots$. Sep, ICP ... & $<1$ & $<1$ & $<1$ & 2 & $<1$ & $<1$ & $<1$ & - & - & 8 \\
\hline Ta..........ppb.......INAA ...... & 17 & 16 & 90 & 237 & 88 & $<20$ & $<\mathbf{1 0 0}$ & - & - & 624 \\
\hline Y $\ldots \ldots \ldots \ldots$ ppm $\ldots \ldots \ldots$ ICP $\ldots \ldots \ldots$ & $<5$ & $<5$ & $<5$ & 15 & $<5$ & 9 & $<5$ & 6.1 & 37.4 & 16 \\
\hline La $\ldots \ldots \ldots . . . . . .$. INApm $\ldots \ldots$ & .71 & 1.59 & 8.2 & 14.0 & 3.26 & 14.7 & .82 & - & - & 20.0 \\
\hline $\mathrm{Ce} \ldots \ldots \ldots \ldots$ ppm $\ldots \ldots \ldots$ INAA. & 1.66 & 1.97 & 12.2 & 26.9 & 14.3 & 4.5 & $<.2$ & - & - & 36.9 \\
\hline Nd ........ppm ........ INAA & $<4$ & $<6$ & 8.0 & 15.2 & 3.9 & 12.6 & $<7$ & - & - & 16 \\
\hline $\mathrm{Sm} \ldots \ldots \ldots \ldots$........... INAA & .248 & .454 & 1.91 & 2.99 & .84 & 3.15 & .117 & - & - & 3.60 \\
\hline $\mathrm{Eu} \ldots \ldots \ldots \ldots$ ppb........ INAA ..... & 57 & 118 & 420 & 690 & 195 & 782 & $<90$ & - & - & 818 \\
\hline $\mathrm{Tb} \ldots \ldots \ldots \ldots$ ppb........ INAA ...... & 22 & 79 & 287 & 422 & 196 & 526 & 35 & - & - & 473 \\
\hline Ho $\ldots \ldots \ldots \ldots$ ppb. .......INAA $\ldots \ldots \ldots$ & $<600$ & $<700$ & $<900$ & 670 & $<900$ & 940 & $<900$ & - & - & - \\
\hline $\mathrm{Yb} \ldots \ldots \ldots \ldots$ ppb........INAA ...... & 151 & 550 & 860 & 1230 & 610 & 1460 & 810 & - & - & 1700 \\
\hline $\mathrm{Lu} \ldots \ldots \ldots \ldots$ ppb. ........ INAA ...... & 28 & 86 & 142 & 226 & 138 & 246 & 169 & - & - & 256 \\
\hline
\end{tabular}

${ }^{1}$ Total $\mathrm{Fe}$ reported as $\mathrm{Fe}_{2} \mathrm{O}_{3}$.

${ }^{2}$ Loss on ignition.

${ }^{3}$ Average of total water content of 6 samples, excluding B44, for which there was insufficient sample for analysis. 
TABLE 6.-Chemistry and mineralogy of selected protoliths from the Buckeye deposit, California Coast Ranges-Continued

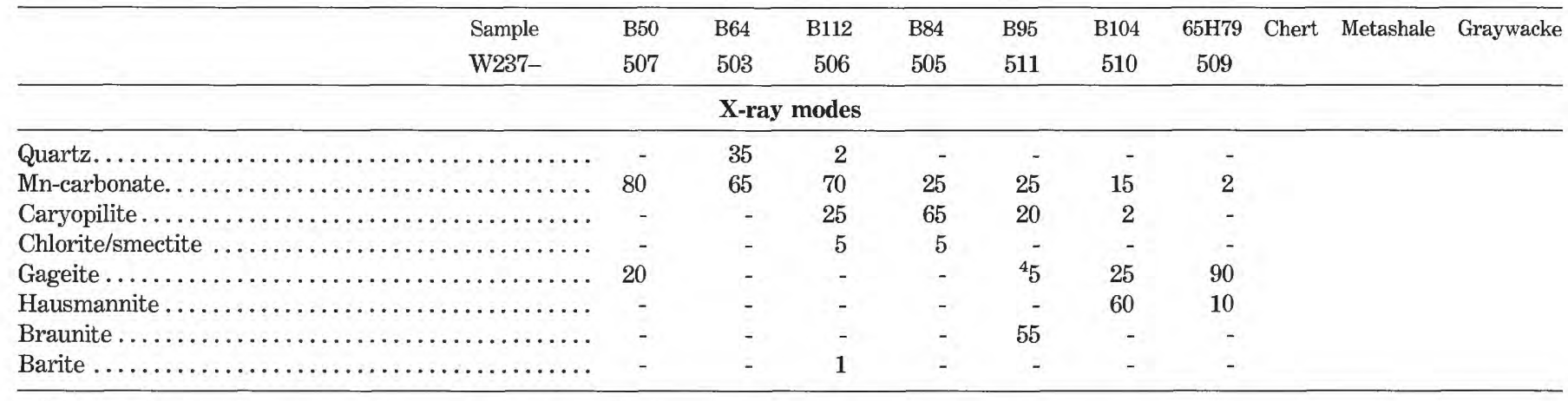

${ }^{4}$ Estimate based on thin-section optics; gageite not observed in X-ray pattern.

or tectonic dismembering. We conclude that transitions between graywacke and chert-metashale sequences did occur in the sedimentary environment but that some of the complicated smaller scale features may be of later origin.

Chert layers consist of more than one lamination and form beds that are commonly 2 to $20 \mathrm{~cm}$ thick. Chert beds are separated by metashale beds (or interbeds), which are several millimeters to $10 \mathrm{~cm}$ thick (fig. 2A). In a general way, the thicknesses of the metashale interlayers are correlated with the color of the chert. Interlayers associated with red chert are comparable in thickness to the red chert layers, interlayers associated with green chert are distinctly thinner than the chert beds, and the metashale partings within white and gray chert beds are insignificant (fig. $2 B$ ), resulting in massive character. Within a lens of chert and metashale layers, individual beds of chert are of uniform thickness rather than thickening in the noses of tight folds or thinning as they approach the lateral outcrop margin of a lens. In unusual cases, individual beds bifurcate or terminate abruptly (see Taliaferro and Hudson, 1943, their figs. 3-4). These observations, combined with the assumption that color was associated with purity of chert, led early students, including Huebner (1967), to think that the rhythmic layering developed during diagenesis. The recognition of laminations and graded bedding within individual layers of chert (Hein and others, 1987a, p. 213) suggests that these chert layers are siliceous turbidites (see Nisbet and Price, 1974).

Folding in the cherts is spectacular (see Huebner, 1967, figs. II-8 and II-10). Sharp folds are common; units of chert on outcrop scale exhibit uniform and symmetric chevron folding (see Johnson and Ellen, 1974). In other places, several sequential chert layers are contorted into S-shapes, yet adjacent layers are not affected. Individual chert layers pass smoothly and continuously about the noses of folds. There is no cleavage. These latter features are characteristic of soft-sediment deformation of layers that remained intact. The chert beds are now cut by quartz veins that do not extend into the adjacent metashale layers. Rare syneresis (shrinkage) cracks in individual chert layers and a brecciated chert reef in which brown chert fragments are engulfed by white silica were noted by Huebner (1967). However, we have the impression that there is little evidence for through-going fractures through which fluids could move perpendicular to layering, although the metashale layers or their contacts with the adjacent chert might provide pathways through which fluids could move parallel to the bedding.

Red cherts have a framework of spherical or elliptical skeletons of radiolaria set in a matrix of radiolarian fragments, iron oxides and hydroxides, and clays. Although the clays may represent a slow yet continuous background deposition of fine clastic detritus, coarse detritus of the kinds found in the graywackes is absent. In contrast to the red chert layers, the green, gray, and white cherts contain only a small proportion of oxidehydroxide-clay component, and skeletal debris is preserved only as ghosts in microcrystalline quartz. Within chert layers of all colors, laminations are indicated by variable concentrations of opaque "dust."

The north Buckeye orebody is enclosed in white chert (locally stained black by supergene manganese oxides) that lacks the metashale interbeds and therefore is described as massive. Actually, the massive chert is composed of chert laminations or, adjacent to the orebody, chert interlaminated with the manganese silicates santaclaraite, caryopilite, and taneyamalite. These laminations impart a fissility that is particularly evident at the surface, above the north orebody. The massive chert reef and the conformably enclosed orebody are folded in an S-shaped kink without major fractures perpendicular to the chert-orebody contact (see Huebner, 1967, fig. II-10; Taliaferro and Hudson, 1943, fig. 8).

The siliceous phase in all cherts and cherty materials examined by us is quartz. Hein and Koski (1987) reported cristobalite-like peaks in X-ray diffraction patterns of silica samples that were associated with manganese. They concluded that emplacement of manganese within 


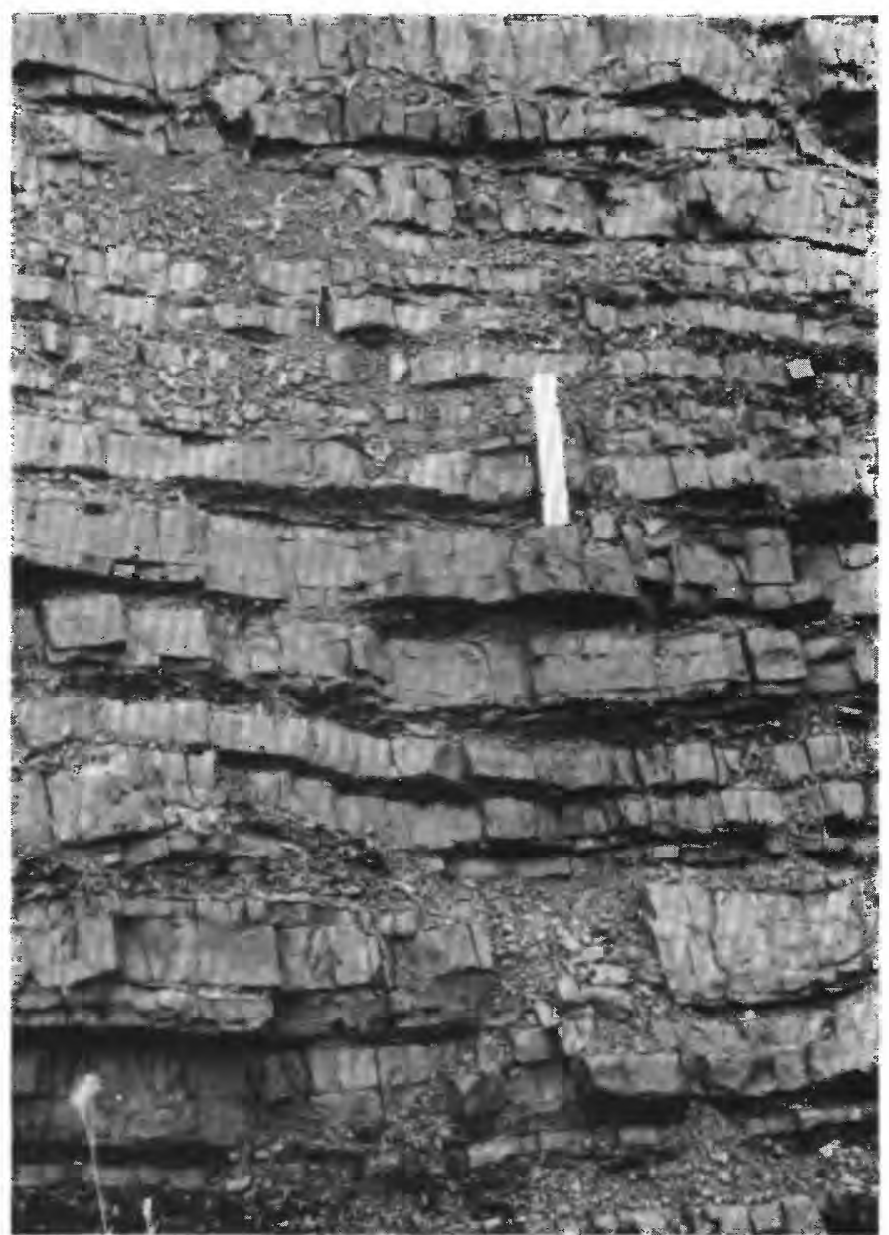

A

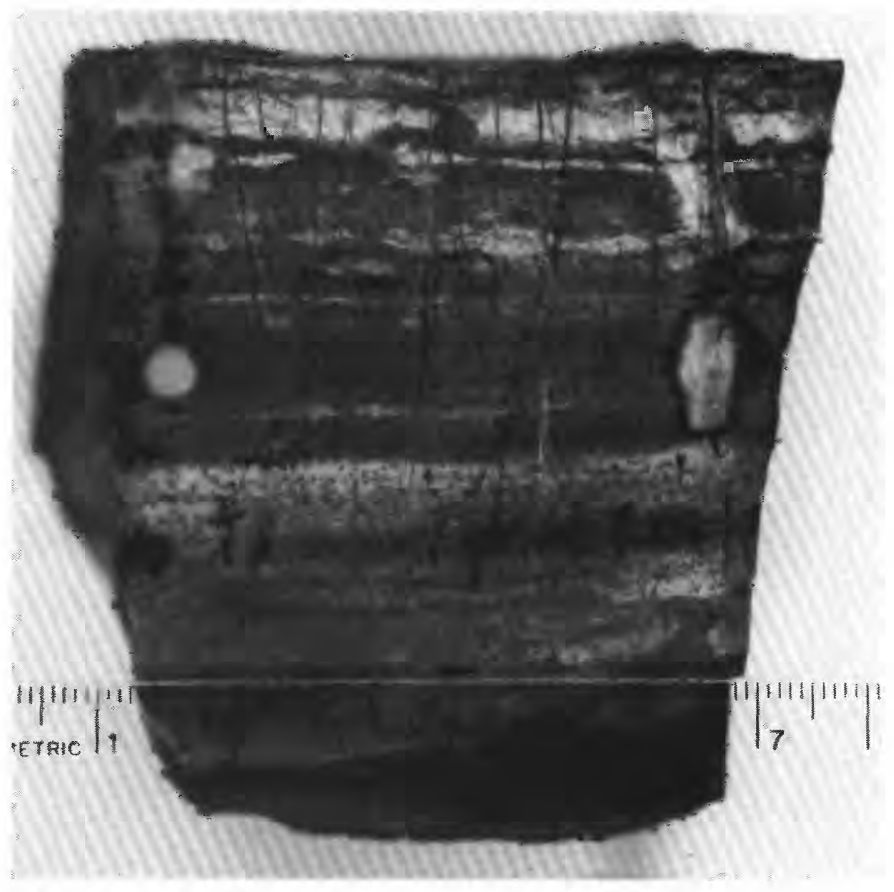

C

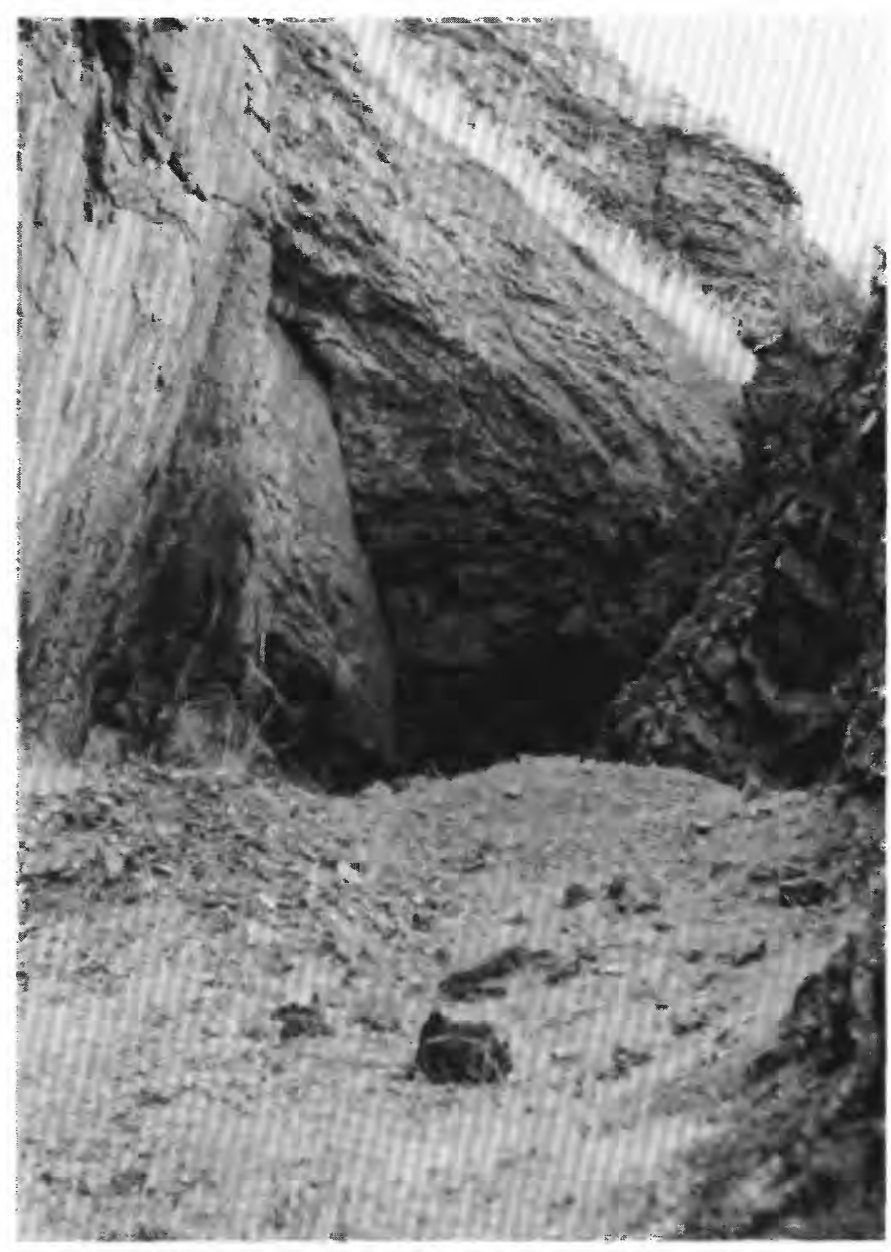

$B$

Figure 2.-Representative chert from near the Buckeye deposit. A, Rhythmic gray chert. Some chert beds are clearly composite. The chert layers are thick relative to the layers of metashale. Scale is $\mathbf{1 6}$ cm long. $B$, Surface outcrop of north orebody in "massive" white chert. The white chert is actually laminated and has some fissility. Width of open cut about $5 \mathrm{~m}$; view is eastward. $C$, Sample $65 \mathrm{H} 66$. Laminated chert from contact with orebody, southeast wall of cut. Laminations are parallel to regional layering in the chert reefs and are caused by varying concentrations of manganese silicates, rhodochrosite, and "dust" (less-than-2- $\mu \mathrm{m}$ particles of clays or oxyhydroxides). The white bleached zones are channels through which fluids passed, leaching manganese minerals and dust and leaving behind pure chert that is more coarsely crystallized than the impure, laminated chert. 
the sedimentary pile arrested the transformation of opal to quartz. In contrast, we found no evidence of any relic opaline phases in the rhythmic chert, in massive chert, in chert interlayered with manganese minerals at the margin of the orebody, or intimately intermixed with manganiferous minerals within the orebody. In the ore lens, much (presumed) skeletal debris has been replaced by rhodochrosite or caryopilite, compositions that have been confirmed by energy-dispersive $\mathrm{X}$-ray analysis. The best preserved textures are "necklaces" of anhedral carbonate crystals that lack the orderly arrangement of skeletal plates of organisms; these necklaces may not originally have been siliceous. In X-ray diffraction patterns, quartz is well crystallized. The quintuplet of peaks resulting from the (122), (203), and (301) reflections is generally well resolved, and the few cases of poor resolution can be attributed to admixed phases. In particular, the $(030)$ reflection of rhodochrosite coincides with the (212) reflection of quartz. The crystallinity index $\mathrm{a} / \mathrm{b}$ (table 7) based on these quartz reflections, which is a qualitative measure of grain size, structural order, and goniometer slit-widths and alignment, averages about 10 on a scale of 11.6. Thus, our values are greater than the values of 6 to 7 (on the scale of 10 proposed by Murata and Norman, 1976) reported by Hein and others (1987). The existence of such well-crystallized quartz is inconsistent with the presence of opaline phases. In a final attempt to confirm the report of opaline silica, we dissolved the carbonate from 11 samples, using $2 \mathrm{~N} \mathrm{HCl}$, but found no reflections attributable to cristobalite or tridymite. Mineral impurities found in the cherts and quartz-rich materials are rhodochrosite, taneymalite, caryopilite, chlorite, smectites with spacings from $15 \AA$ to $25 \AA$, acmitic clinopyroxene, and iron oxyhydroxide (table 7).

The discovery of chert and volcanism in modern deep ocean basins has led to the use of major-element compositions to distinguish between pelagic (organic), detrital (abiogenic), and hydrothermal sources of silica (Adachi and others, 1986; Yamamoto, 1987). By this reasoning, the hydrothermal component is $\mathrm{Fe}$ - and $\mathrm{Mn}$-rich and $\mathrm{Al}-$ and Ti-poor, the detrital component is Al- and Ti-rich, and the pelagic component has low concentrations of all four elements. Hein and others (1987) presented average compositions for 35 cherts, 4 argillaceous cherts, 7 siliceous argillites, and 7 argillites (metashales) from the Ladd-Buckeye district. The compositional contrast of these rocks with Franciscan cherts and shales deposited above metabasalt is striking (Yamamoto, 1987). At the Buckeye, the cherts appear to be pelagic with a minor detrital, rather than hydrothermal, component. The interbedded metashales have $\mathrm{Al}_{2} \mathrm{O}_{3}$ and $\mathrm{TiO}_{2}$ contents that are similar to those of average shales and graywackes; thus the Buckeye metashales appear to have a significant detrital component, perhaps related to the finest fraction of the graywacke. Later we will show that the rare-earth-element (REE) patterns of the cherts and shales mimic the patterns for the graywackes, reflecting an REE-rich detrital component. However, because the detrital (graywacke) component tends to be REEenriched, even a small proportion of detrital component could obscure the contribution of a hydrothermal component to the REE pattern for the chert or metashale. Complete trace-element data for all three rock types might permit better estimates of the proportions of detritus.

\section{PROVENANCE}

Sediments of the Grummett broken formation, host of the Buckeye manganese deposits, were predominantly clastic, both biogenic and abiogenic. The metashale interbeds associated with the chert may in part represent a chemically precipitated component, perhaps of hydrothermal origin, but the proportion of such a component, if present, is uncertain. The biogenic flux consists of radiolarian debris and whatever pelagic contribution is contained in the metashales and thus was ultimately derived from a marine water column. The abiogenic flux is represented by the conglomerates, metagraywackes, and associated shales, and a background component of clays that formed the metashales. Clasts of chert, shale, porphyritic volcanic rocks, plagioclase, coarse quartz, and chromite found in the conglomerate and graywacke cannot have come from a single lithologic source. Three or four sources are needed: one of low metamorphic grade, perhaps within the Franciscan Complex itself; a quartz-bearing igneous or metamorphic terrain, perhaps a continental margin or magmatic arc; an ultramafic (or ophiolitic) terrain that could provide the detrital chromite; and an ultramafic to mafic source that could provide the iron- and magnesium-rich graywacke matrix.

\section{REGIONAL METAMORPHISM}

The presence of lawsonite + quartz + albite + chlorite and minor glaucophane, combined with the absence of zeolite, zoisite, and epidote, indicates metamorphic conditions between 175 and $300{ }^{\circ} \mathrm{C}$ and greater than $4 \mathrm{kbar}$ (fig. 3; see also Cotkin, 1987). Because aragonite is known to transform readily to calcite at low pressure, the presence of calcite within the Grummett broken formation is not diagnostic. However, the presence of aragonite-bearing veins in the graywacke near the boundaries of the Grummett broken formation is an indicator of the minimum pressure achieved in the veins 
TABLE 7.-Characterization of siliceous samples from the Buckeye deposit, Califormia Coast Ranges, by X-ray powder diffractometry [Color terms from Goddard and others (1970). Estimated intensities of X-ray powder diffraction intensities: S, strong; M, moderate or moderately; W, weak; VW, very weak; -, not observed.

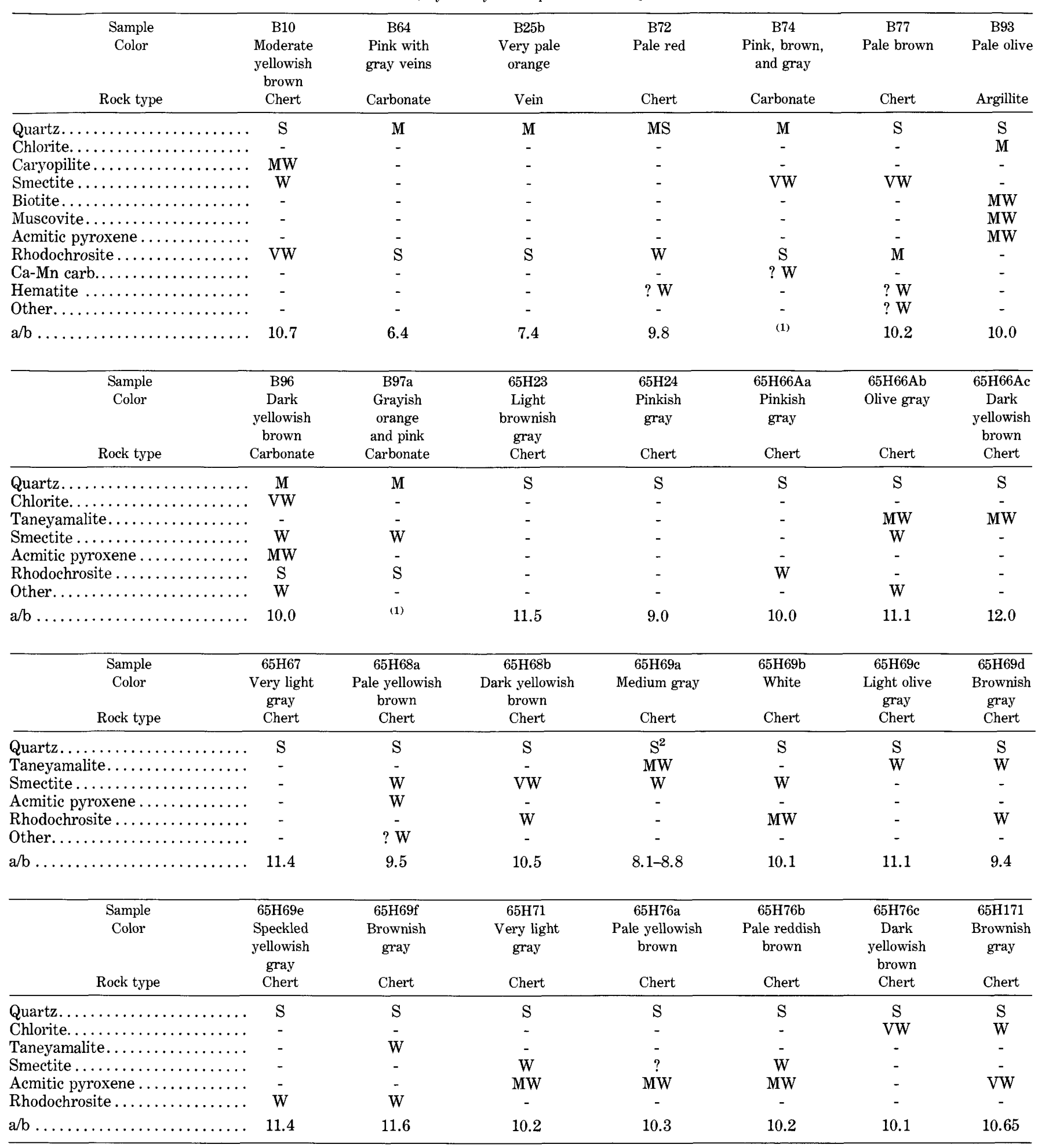

${ }^{1}$ Unable to determine crystallinity index because of interference by $(030)$ peak of rhodochrosite.

${ }^{2}$ Weak reflection present at $21.8^{\circ}$ is too sharp for opal. 


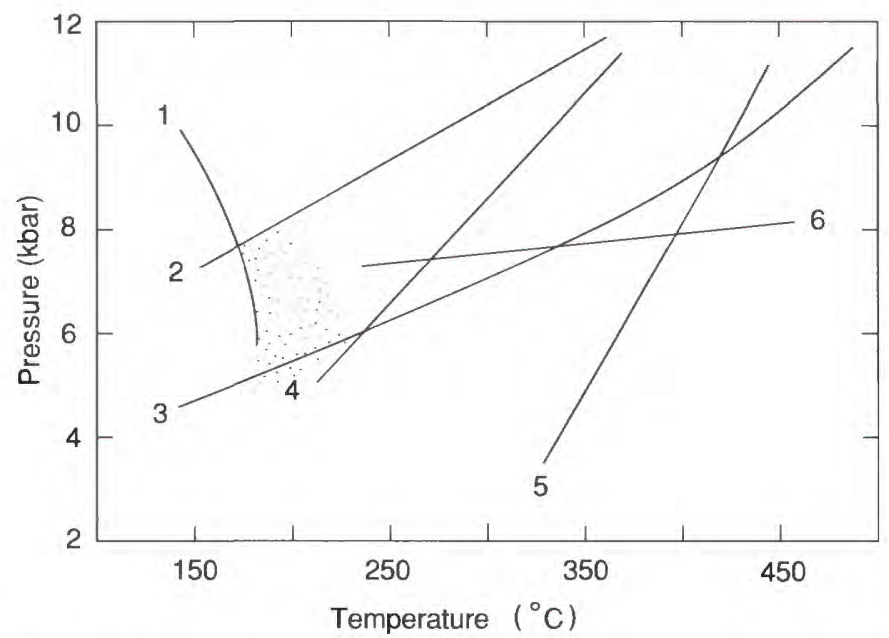

FiguRE 3.-Pressure-temperature grid for metagraywacke. All reactions are written with the high-temperature assemblage on the right side of each equation. 1 , heulandite = lawsonite + quartz + fluid. 2 , jadeite + quartz $=$ low albite. 3 , aragonite $=$ calcite. 4 , lawsonite + glaucophane $=$ epidote + chlorite + albite + quartz + fluid. 5, lawsonite + albite $=$ zoisite + paragonite + quartz + fluid. 6 , glaucophane + clinozoisite + quartz + fluid $=$ tremolite + chlorite + albite. In the vicinity of the Buckeye deposit, the assemblage is lawsonite + quartz + albite + chlorite \pm glaucophane. Aragonite is nearby. Pumpellyite, jadeite, and members of the zoisite group are absent. Pressures of 4 to $7 \mathrm{kbar}$ at $180^{\circ} \mathrm{C}$ or $10 \mathrm{kbar}$ at $300{ }^{\circ} \mathrm{C}$ are possible. We favor temperatures of no greater than $175-250{ }^{\circ} \mathrm{C}$ (stippled area) for the Buckeye deposit because relic gel-like materials are present and a pervasive metamorphic fabric did not develop. Curves largely after Cotkin (1987, fig. 3); the calcite-aragonite curve is from Johannes and Puhan (1971).

and tentatively is regarded as an indicator of minimum pressure within the Grummett unit, 5 kbar at $180{ }^{\circ} \mathrm{C}$ (Johannes and Puhan, 1971). The occurrence of jadeite + albite + quartz in other samples from within the Grummett broken formation (Raymond, 1973a,b) suggests that the peak metamorphic pressure might have been 7-8 kbar $\left(\right.$ at $180^{\circ} \mathrm{C}$ ). Although temperature and pressure estimates of such assemblages are uncertain, the preservation of palimpsest features, the development of only an incipient foliation, and the disordered state of the sheet silicates suggest metamorphism at the low-temperature end of the range of conditions, perhaps 150 to $200^{\circ} \mathrm{C}$ and 7 to 8 kbar. Maintenance of relatively low temperatures at such high pressures requires a low geothermal gradient. If hydrothermal convection of the kind proposed by Lonsdale (1977) or Crerar and others (1982) was involved in the deposition of manganese at the Buckeye, metamorphism could not have occurred in the presence of the hydrothermal heat engine. This separation of processes could have been brought about by allowing the heat source to decay with time or by moving oceanic crust with its mantle of sediments and manganese deposits away from the heat source before subduction.

\section{PROTOLITHS}

The goal of this study has been to look back through metamorphic and diagenetic overprints to characterize the original sediments that resulted in the north Buckeye and, by analogy, other orebodies of the Franciscan Complex. Without knowledge of the original nature of these materials, it is impossible to deduce their origins. By volume, four phases (rhodochrosite, caryopilite, braunite, and hausmannite) compose virtually the entire orebody. Ten phases form monomineralic or almost monomineralic layers with sedimentary characteristics. Many of these phases also occur as mixtures that form other layers. We are confident that six kinds of layers and laminations have a sedimentary origin and thus represent compositions, if not mineralogies, of distinct sedimentary components, albeit now dehydrated and to some extent recrystallized. Two more minerals probably represent sedimentary components. Each of these sedimentary protoliths is named on the basis of its characteristic mineralogical component: chert, rhodochrosite, caryopilite, chlorite, hausmannite, braunite, and perhaps taneyamalite and gageite. (Nominal formulas for these minerals are given in table 1.) A layer rich in diopsidic acmite also has sedimentary characteristics. In addition, talc occurs as a green lens in brown chert (B10) but is too rare to be considered a component that influences the composition of the orebody. In the following paragraphs, we describe the occurrence of these materials, making reference to the series of photographs arranged to show increasing disruption of original layering (fig. 4). Seven homogeneous layers were sampled to yield $25-$ to $50-\mathrm{g}$ splits for initial major- and trace-element analyses. The large sample size, in some cases, prevented removal of a pure sedimentary component. These seven samples (table 6) represent rhodochrosite, caryopilite, gageite, hausmannite, and braunite protoliths. Layers of chlorite and taneyamalite are too thin and of insufficient lateral extent to sample for bulk chemical analysis (1 gram) without contamination by other protoliths and are chemically characterized only by electron microprobe techniques. Average chert and metashale analyses can be found in Hein and others (1987) and are summarized in table 6 . In describing the protoliths, we give the characteristic X-ray reflections so that later workers will be encouraged to identify these phases in fine-grained mixtures, using X-ray powder diffractometry. We hope that our observations will be found to be generally applicable to many deposits of the Franciscan Complex and elsewhere.

\section{CHERT}

Chert surrounds the orebody but is not interlayered with the other protoliths. From this fact, we infer that 


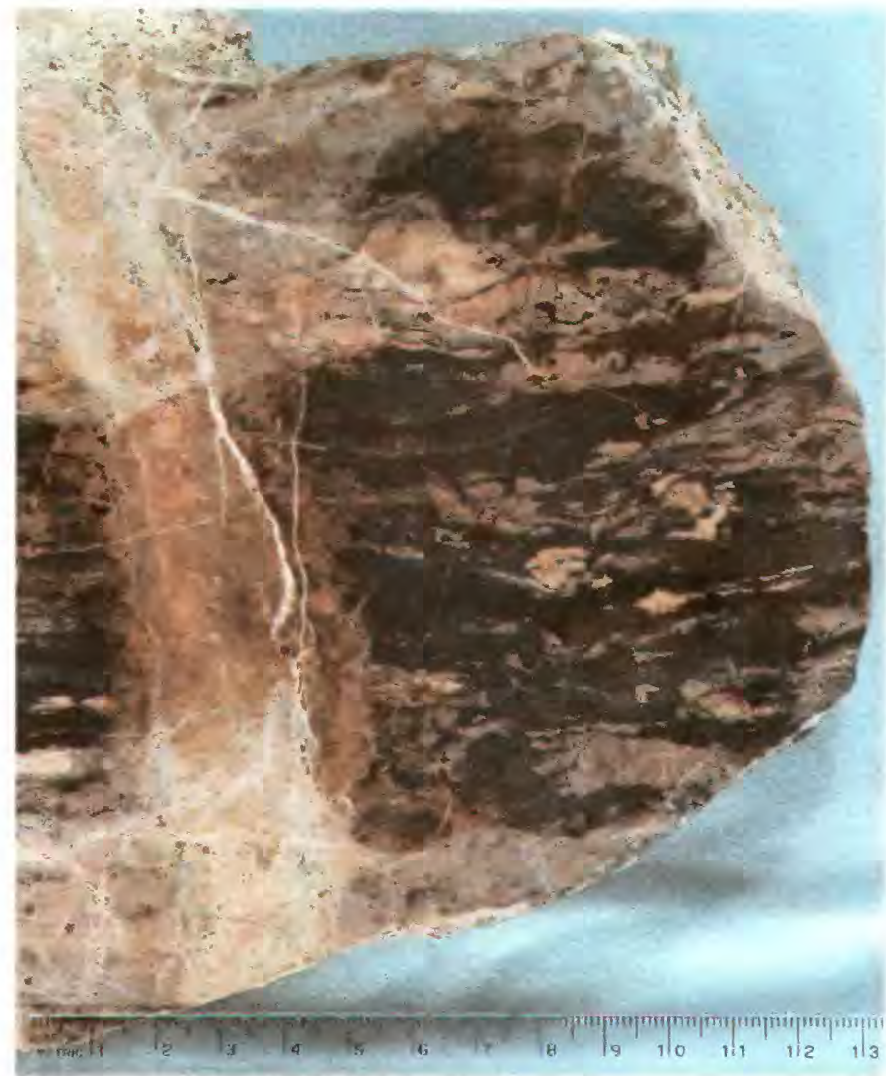

$A$

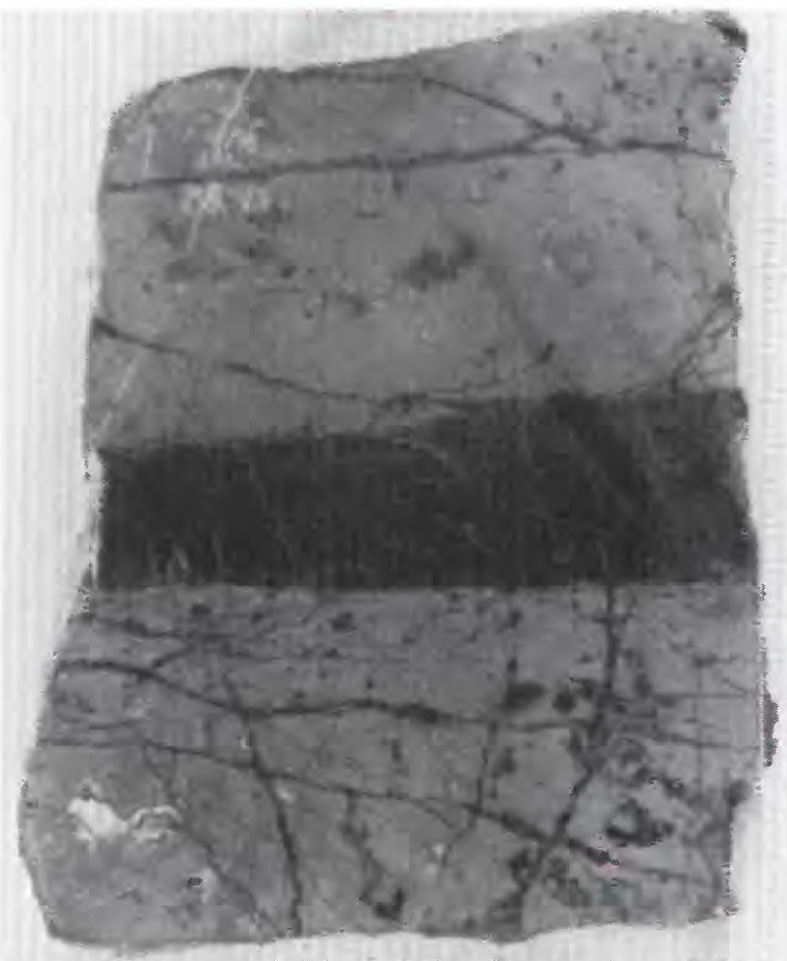

B

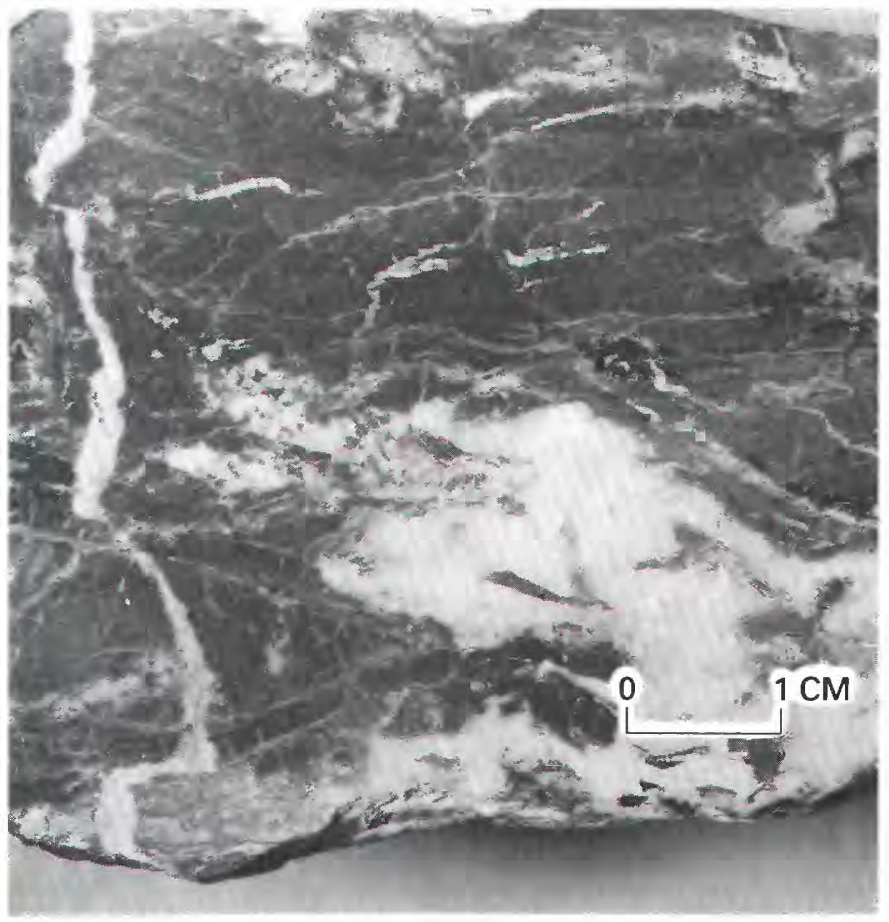

C

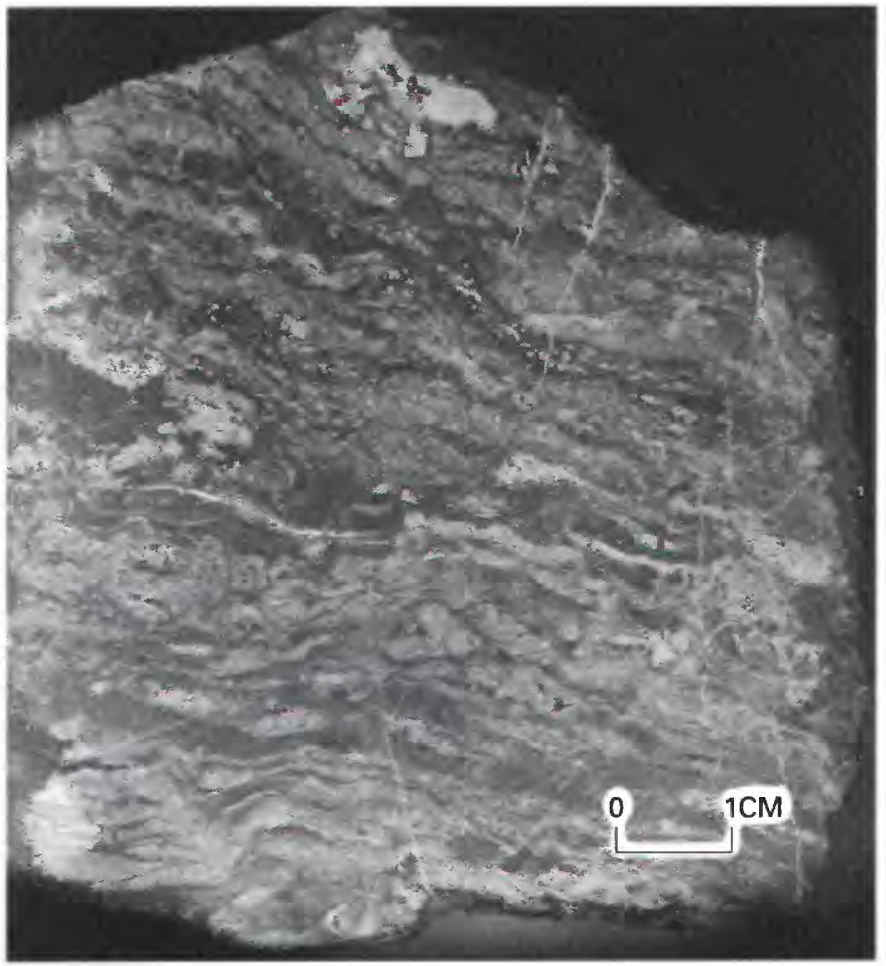

D 


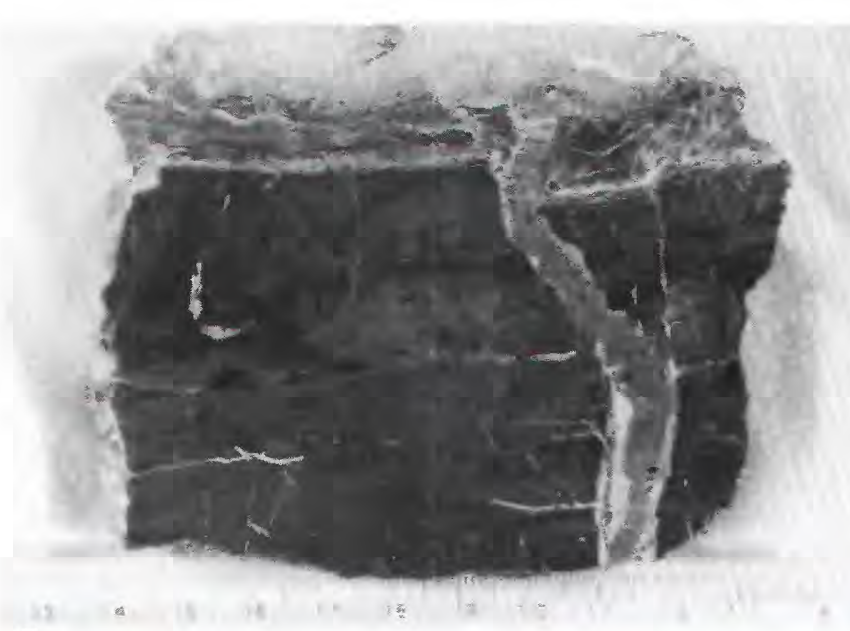

E

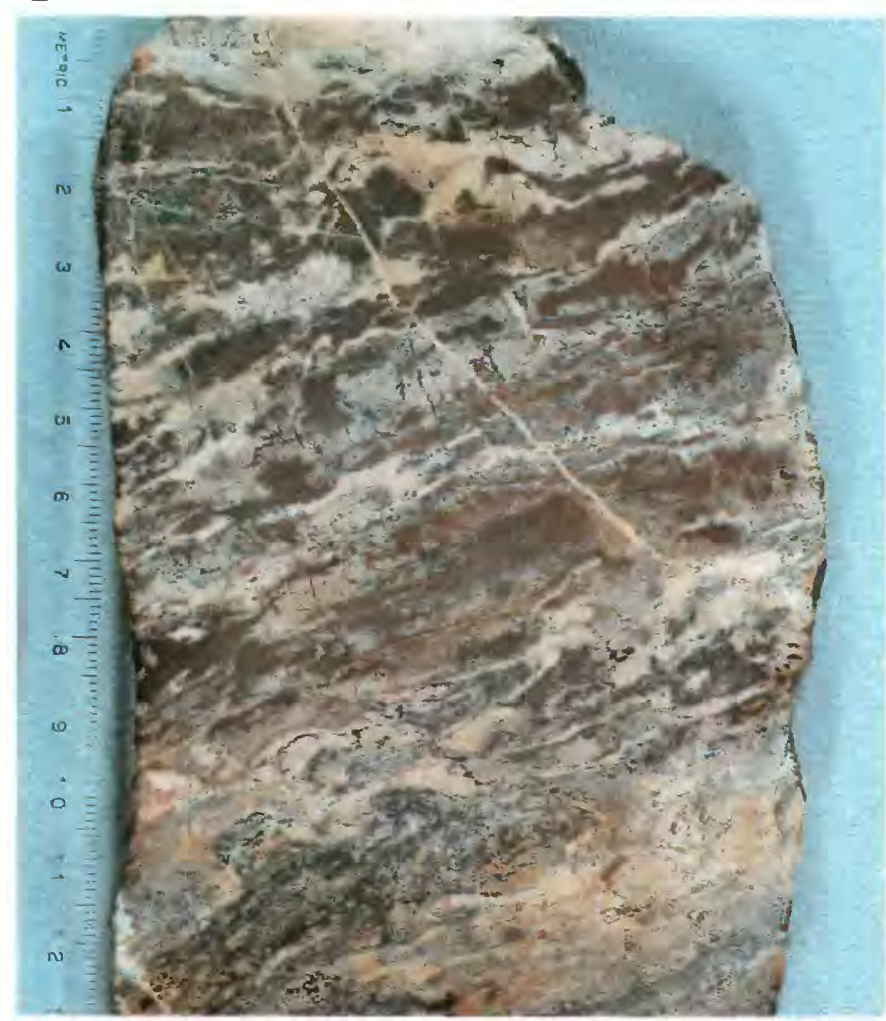

G

FIGURE 4.-Slabbed hand specimens of different protoliths from the Buckeye deposit, California, arranged to show increasing degree of soft-sediment deformation. Following the scale of Raymond (1984), coherent units are disrupted, then dismembered, and finally only relics of beds are seen engulfed in a once-fluid matrix to form a melange. A, Sample B87. Alternating layers of caryopilite, hausmannite disseminated in rhodochrosite, and rhodochrosite. Layering is still fairly coherent despite late polymineralic veins and recrystallization of rhodochrosite (grayish-pink pods). $B, 65 \mathrm{H} 79$. Thick layer of gageite (black) in massive hausmannite (dark gray). Thin veins of gageite originated in the thick layer. $C, \mathrm{~B} 25$. Coherent layers of caryopilite can be traced across hand specimen despite brecciation and the presence of late white veins of quartz, rhodochrosite, smectite, and relic santaclaraite. D, B26. Alternating layers of caryopilite (dark gray) and rhodochrosite. Layers are still coherent, even though much of the carbonate has recrystallized to spherules. $E, \mathrm{~B} 84$. Coherent interlaminations of chlorite, rhodochrosite, and caryopilite (top). The thick caryopilite layer (bottom) is internally brecciated, making it impossible to follow individual bedding laminations across the hand specimen. $F, \mathrm{~B} 81-1$. Disrupted braunite-rich
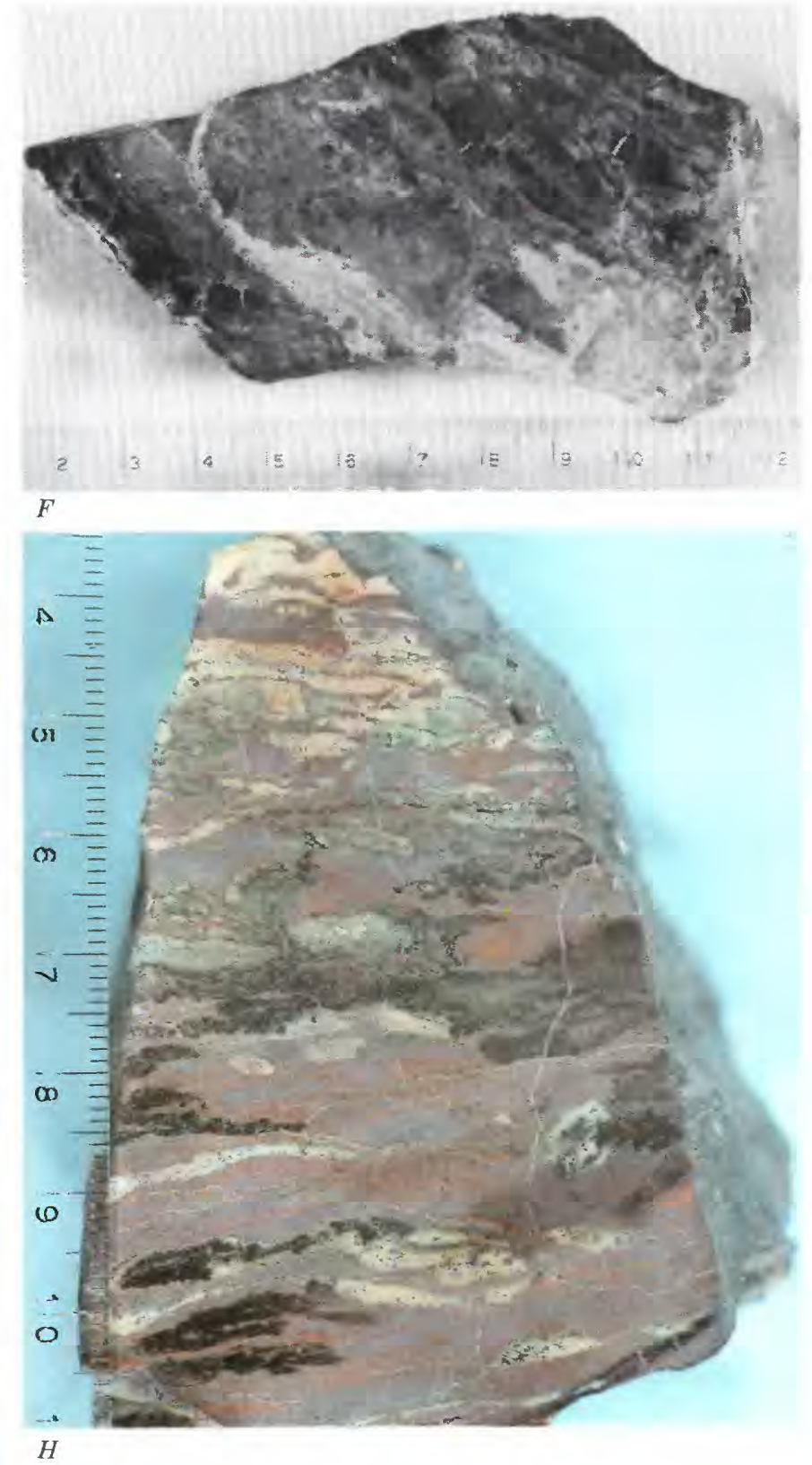

layers (dark gray) in carbonate-rich material (light gray). The slightly displaced breccia fragments can be mentally and visually rearranged, permitting some layers and laminations to be traced across the specimen. $G$, B53. Layers of braunite (black), hausmannite (grayish red), and rhodochrosite (grayish pink); texture is intermediate between disrupted and dismembered. Upper and lower surfaces of individual layers and laminations are indistinct. Displacement of breccia fragments is so great that reconstruction into continuous layers is not certain, but compositional contrast clearly indicates orientation of original bedding. $H, 65 \mathrm{H} 86$. Dismembered layers of gageite (black) and rhodochrosite (grayish pink) in hausmannite and rhodochrosite (grayish red). Layer contacts are indistinct; reconstruction of the layers is not possible. Compositional contrast still suggests orientation of bedding. I, B58. Gray rhodochrosite protolith, with slightly grumous texture, and gageite (black). We interpret this specimen originally to have been interlayered rhodochrosite and gageite. Disruption has been so intense that the orientation of original layering is not evident, giving it a massive nature. $J$, B78. Massive micromelange of rhodochrosite (grayish pink), hausmannite disseminated in rhodochrosite, caryopilite, and braunite (black). Neither individual layers nor the orientation of bedding is clear. Scale in centimeters. 

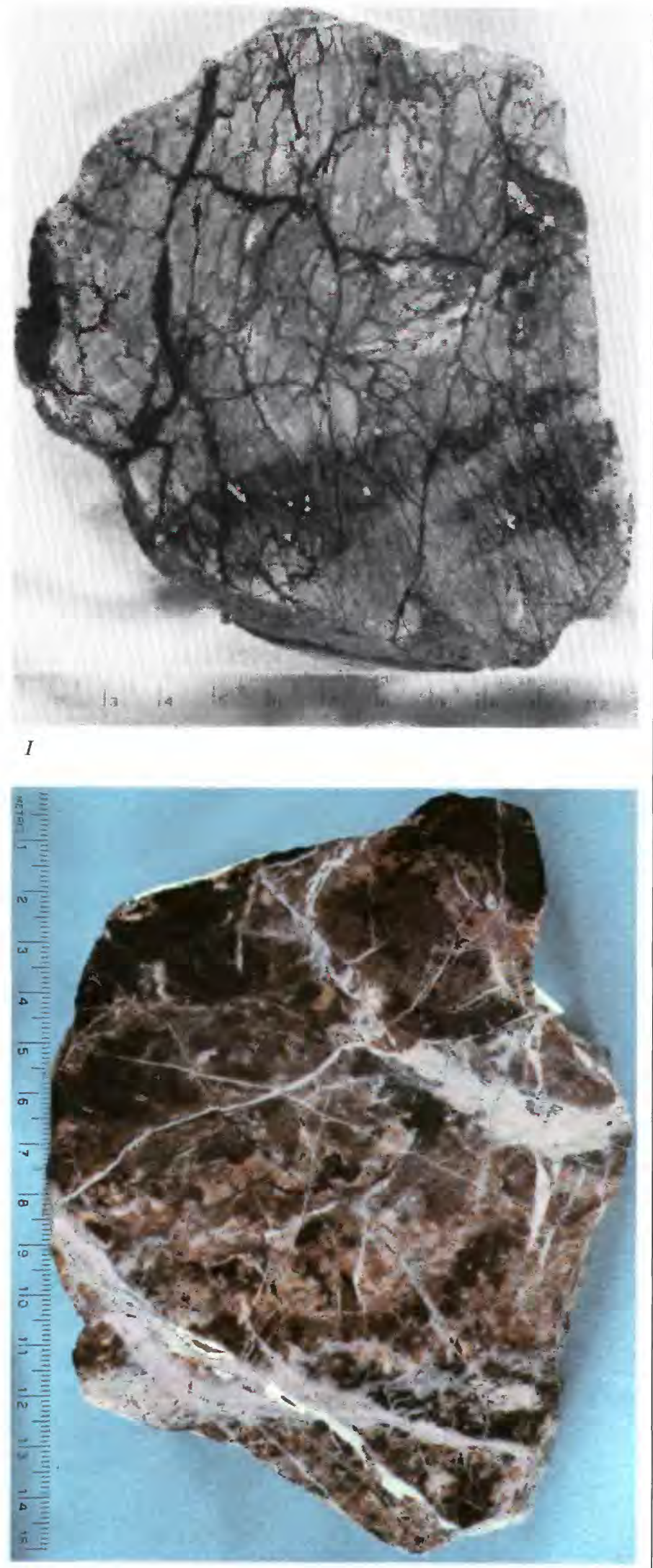

Figure 4.-Continued. chert does not occur within the ore lens. Massive chert contains manganiferous laminations (1 to $5 \mathrm{~mm}$ thick) adjacent to the orebody, but the laminations are nonmanganiferous away from the contact. The distinction between laminae is based on impurities. The least pure chert laminations are made cloudy by opaque "dust" (presumably oxides and hydroxides) and by smectite. Impure layers are characteristically fossiliferous, have fine-grained quartz, and, adjacent to the orebody, may contain bundles of manganese-silicate fibers. The pure layers are devoid of dust and smectite, do not preserve fossils, are composed of more coarsely crystallized quartz, and may contain irregularly shaped or rhombohedral bodies of carbonate. In the transitional interval of at least several centimeters surrounding the north orebody, the chert contains thin laminations of manganiferous sheet silicates, which cause partings, and some of the chert contains santaclaraite (figs. $5 C, D$ ). Chert laminations are coherent to disturbed; soft-sediment deformation has not been extensive. Impure laminae are transected by irregularly shaped bleached zones of wellcrystallized pure chert; the boundaries between impure laminae and bleached zones are gradational (fig. $2 C$ ). These bleached zones mark the pathways by which fluids escaped from the soft sediment. Rarely, laminations have been disrupted perpendicular to layering (fig. $5 D$ ), as if fluid had pushed through the laminations. This toe-like texture was probably formed by escaping fluids during compaction and diagenesis. Veins of coarsely crystallized quartz have sharp contacts, rarely contain bundles of manganese silicate fibers, and were clearly formed after the siliceous sediment was indurated. Although there is evidence that solutions removed manganiferous components from the chert (figs. $2 C, 5 C$ ), there is no indication that the manganiferous laminations were introduced by vein-forming processes (fig. $5 \mathrm{C}$ ). Within the chert, these manganiferous laminations appear to be primary sedimentary features.

The average chemical compositions of chert and metashale in the Ladd-Buckeye district (Hein and others, 1987) are compared with the compositions of the manganiferous protoliths in table 6 . The major distinctions are that chert has a smaller $\mathrm{Mn} / \mathrm{Fe}$ and, in terms of absolute concentrations, more $\mathrm{Na}$ and $\mathrm{K}$. There is less $\mathrm{Mn}, \mathrm{Mg}$, $\mathrm{Ca}, \mathrm{CO}_{2}, \mathrm{Ni}, \mathrm{V}$, and $\mathrm{Zn}$ in the chert than in the seven manganiferous samples analyzed, but, because the large amount of silica tends to dilute the concentration of all other constituents, the smaller values are not unexpected. Clearly, the chert is not mineralized. The REE patterns of the chert and Mn sediments are similar (see fig. 7). In general, the Ce anomaly (relative to seawater) is distinct in chert.

The analyses of metashale are dominated by a fine clastic sediment component (represented by 0.875 
weight percent $\mathrm{TiO}_{2}$ ). Copper and nickel concentrations exceed the small amounts expected of graywackes (Taylor and McLennon, 1985) and could be due to Mn-poor mineralization. The REE patterns of the metashales are similar to, but more enriched than, those of the graywackes (fig. $7 \mathrm{~A}$ ). Ce anomalies are prominent in both. This similarity suggests that the pattern is being dominated by the finest fraction of the turbidites; any contribution to the REE pattern that resembles the patterns of Buckeye ores (fig. $7 \mathrm{~A}$ ) is obliterated by the presence of the clastic material.

Hein and others (1987) and Hein and Koski (1987) argued that the Buckeye orebody formed by the replacement of chert by rhodochrosite and suggested that the silica released by this process contributed to the formation of the massive cherts. It is important to realize that many of the laminations in the massive chert contain relic skeletal debris and that some of these laminations preserve frameworks supported by flattened radiolarians. We conclude that most or all of the laminations were originally composed of the debris of pelagic organisms with variable amounts of smectite and oxide-hydroxide "dust." Thus, a direct major flux of silica from the site of rhodochrosite deposition to the site of massive chert accumulation is precluded, making it unlikely that massive chert could form as a direct consequence of ore formation. Further, if an orebody with the size and manganese concentration of the Buckeye were formed by replacement, one might find a halo of replacement features about the orebody. There are no such features. The manganese components that occur in massive chert appear to have been deposited with the massive chert.

\section{RHODOCHROSITE PROTOLITH}

Manganese carbonate appears to be the most abundant mineral at the Buckeye deposit, but this abundance may be in part an artifact of the selective mining of higher grade oxide-rich (hausmannite and braunite) ore (Huebner, 1967). Carbonate protolith is best preserved in samples B42, B50, B58 (fig. 4I), B103, and B107; it now consists of extremely fine-grained, medium-gray rhodochrosite that is so turbid in thin section that the characteristic optical properties of carbonate cannot be recognized (fig. $5 \mathrm{~A}$ ). The rhodochrosite protolith can be identified by the $(012),(104)$, and $(018,116)$ reflections at $24.2^{\circ}, 31.4^{\circ}$, and $51.8^{\circ}$ in XPD patterns made with copper radiation. The (104) of rhodochrosite is so strong that it is a sensitive indicator of as little as 2 percent carbonate in mixtures. However, the (012) reflection overlaps with the (002) of caryopilite. Partial recrystallization to coarser, lighter gray rhodochrosite results in a grumous texture with distinct optical properties in thin section. More advanced recrystallization results first in light- gray carbonate and loss of the patchy texture (as in samples B17, B28, B108) and ultimately in pink rhodochrosite (B64, B69, B73, B74, and B98). Small segregations of clear yellow, sensibly isotropic gel-like material (B50, figs. $6 G, H$ ) occur within the gray carbonate. The carbonate forms a breccia of equant to tabular bodies, 0.5 to $3 \mathrm{~cm}$ in size and with irregular to serrated margins, that are separated by selvages of gageite (B45, fig. $5 \mathrm{~A}$; B50, B58, B108). We interpret the finest grained darkgray carbonate to be relic primary carbonate. The yellow bodies are relic gel-like materials, residues of a siliceous component that presumably once was more uniformly distributed throughout the carbonate. Small amounts of smectite similarly occur in several samples. The gel-like material may have imparted a sufficiently cohesive quality to the fine-grained carbonate (micrite) that it fractured into equant bodies, about which gageite flowed. In other samples, the micrite flowed about broken layers of caryopilite (B54) and of braunite and gel-like material (B71b, figs. $6 A, B)$.

The chemistry of the rhodochrosite protolith, represented by B50 (table 6), illustrates the enrichment of manganese relative to iron and titanium (and most other major rock-forming oxides). The mineralogy consists of rhodochrosite, gageite, and devitrified or partly devitrified gel-like material of chlorite composition and is consistent with the bulk chemistry. The $\mathrm{CO}_{2}$ concentration is 23.6 percent by weight, compared with 38 percent for pure rhodochrosite. $\mathrm{Al}$ and $\mathrm{Mg}$ are associated with yellow, partially devitrified gel-like material of chlorite composition, and silica is contained in gageite and the gel. $\mathrm{Zn}, \mathrm{Mo}, \mathrm{Ni}, \mathrm{As}, \mathrm{Ti}, \mathrm{B}$, and $\mathrm{W}$ are the only trace elements that are present in concentration greater than $25 \mathrm{ppm}$. Compared with other protoliths from the Buckeye deposit, rhodochrosite has low concentrations of REE (fig. $7 B$ ). The Ce anomaly is not well defined, perhaps due to the fact that $\mathrm{Nd}$ values for carbonate were below the detection limit. However, Sm values are higher than would be expected if the Ce anomalies were prominent. In comparison with many manganiferous marine sediments, particularly most ferromanganese nodules and pavements, the carbonate and other protoliths from the Buckeye deposit contain small concentrations of $\mathrm{Co}, \mathrm{Ni}, \mathrm{Cu}$, and $\mathrm{Ba}$.

\section{CARYOPILITE PROTOLITH}

Caryopilite is found in claylike masses (B38; B84, fig. $4 E$ ), weakly foliated layers (B20, fig. $5 B$; B25, fig. $4 C$ ), and thin, well-foliated layers (B26, B54) and fragments of layers (B24, B83). The most poorly crystallized caryopilite is claylike (or rarely gel-like) and represents dewatered protolith. Caryopilite is identified by its (001), (002), (20-1, 130), and (20-2, 131) X-ray reflections at 


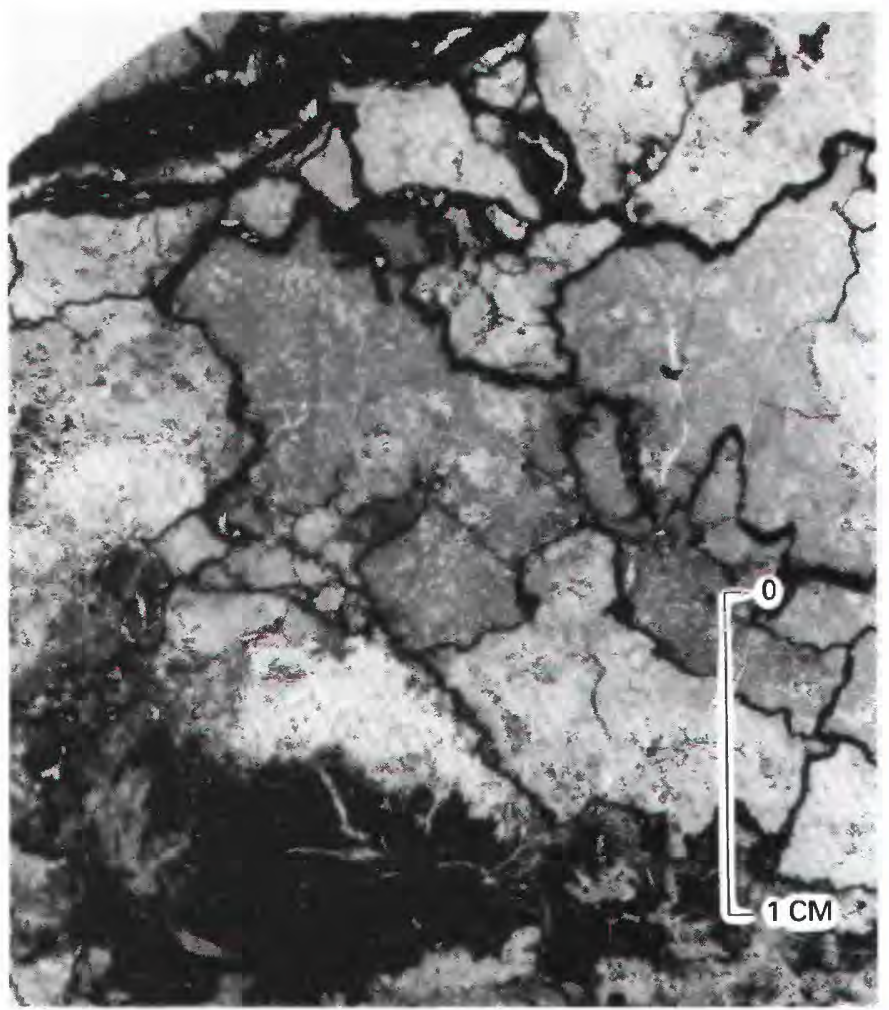

A

Figure 5.-Characteristic microscopic features of protoliths in the Buckeye deposit, California. A, Sample B45. Serrated septa of dark-red to opaque (black in photograph) gageite surround irregular fragments of extremely fine grained rhodochrosite mud. This texture is presumably caused by soft-sediment deformation of interlaminated carbonate and gageite, not by late-stage hydrothermal veining. $B$, B20. Interlaminated caryopilite (c) and taneyamalite (t). Taneyamalite is squeezed from primary layer and intrudes caryopilite layers. Note presence of transparent caryopilite, designated cg. $C, 65 \mathrm{H} 76$. Brecciated santaclaraite-bearing chert cut by quartz veins. The

$12.0^{\circ}, 24.3^{\circ}, 32.0^{\circ}$, and $35.8^{\circ} \mathrm{CuK \alpha}$, respectively, in accordance with the indexing by Guggenheim and others (1982). We also observed broad reflections at $56.5^{\circ}$ and $58.0^{\circ}$. In thin section, the relatively high birefringence of claylike caryopilite distinguishes it from chlorite. Evidence that some caryopilite may have originated as gel-like material is the occurrence of transparent layers of clay-sized particles that may represent devitrifying gel (B20, fig. 5B) and one occurrence of isotropic gel-like material with caryopilite composition (B91, fig. $8 D$ ). In claylike mixtures, the presence of caryopilite is best indicated by its X-ray pattern or composition. The caryopilite protolith commonly occurs as 0.5 - to 3 -mm layers interlaminated with carbonate or, less commonly, with taneyamalite or chlorite. Ghostlike outlines of spheroidal skeletal debris are present, and transparent orangebrown ovoids (skeletal casts of radiolaria?) are rare (B38). Dismembered caryopilite layers are engulfed by carbonate (B24), caryopilite-carbonate mixtures (B39),

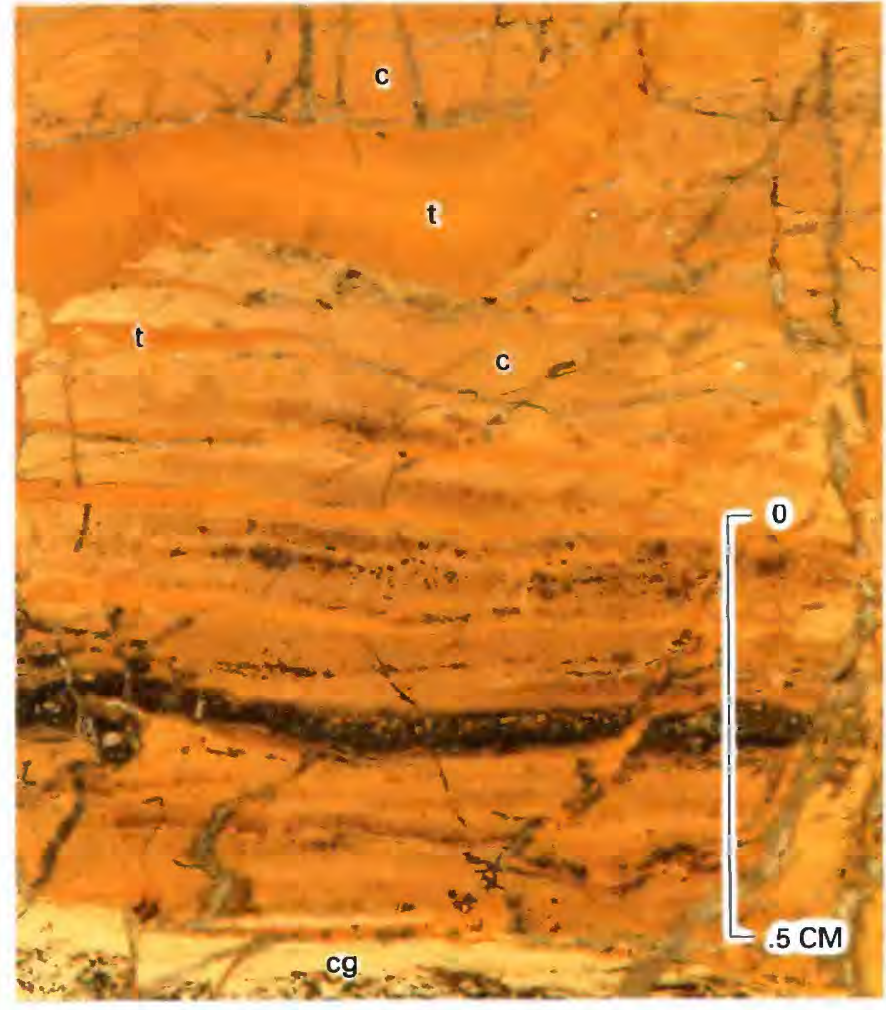

$B$

abundance of santaclaraite is controlled by bedding laminations, and this mineral clearly was not introduced by the later, crosscutting vein fluids. $D, 18591 \mathrm{C}$. Dewatering texture in laminated chert. Dark layers are manganiferous sheet silicates (top); discrete crystals are santaclaraite. Fluids moved perpendicular to layering, cutting across earlier manganiferous laminations. Compare with similar texture in braunite, in $E$. $E$, B95. Dewatering texture in braunite, similar to dewatering texture in chert (compare with $D$ ). Reflected light. $F$, B95. Thin laminations with braunite composition. Note also the coarse euhedra of braunite.

or taneyamalite (B20, fig. $5 B$; B29) or form spectacular intraformational microbreccias (B83; B84, fig. 4E).

The composition of the caryopilite protolith is represented by B84 (fig. $4 E$ ). The analyzed split consists of caryopilite with minor rhodochrosite and chlorite or smectite. Again, the mineralogy is consistent with the chemistry (table 6): $\mathrm{Al}$ and $\mathrm{Mg}$ reflect the chlorite/smectite and $\mathrm{CO}_{2}$ the carbonate. The $\mathrm{FeO}$ content is greater in B84 than in the carbonate protolith (B50) and reflects the presence of caryopilite. The value for Mo, $740 \mathrm{ppm}$, is unusually high and is due to intimate intergrowths of fine-grained (less than $5 \mu \mathrm{m}$ ) flakes of molybdenite and caryopilite. This intergrowth has a patchy distribution but is not obviously related to the late veins that cut the sample (fig. $4 E$ ). The increased Ba value, relative to B50, is probably due to postdepositional replacement by barite. Although barite has not been found in thin sections of $\mathrm{B} 84$, it occurs as veins in B29 (caryopilite), B31 (dolomite near contact between Grummett and Sulphur Gulch bro- 


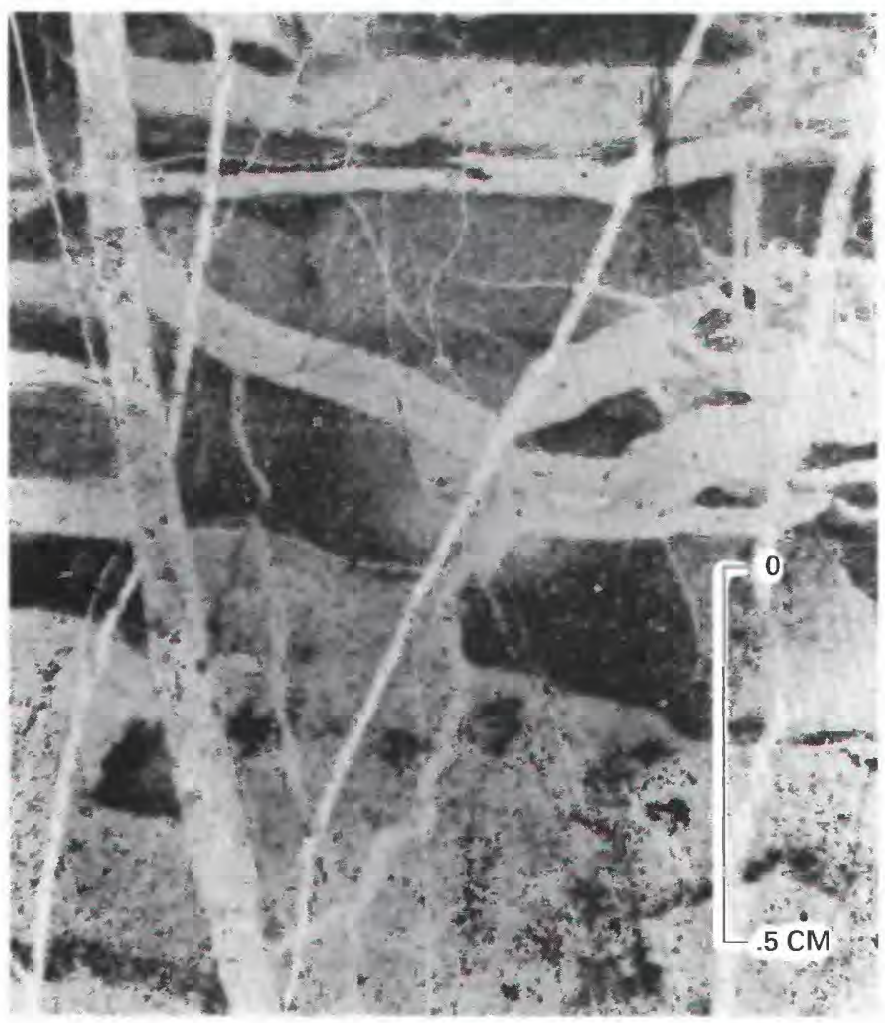

C

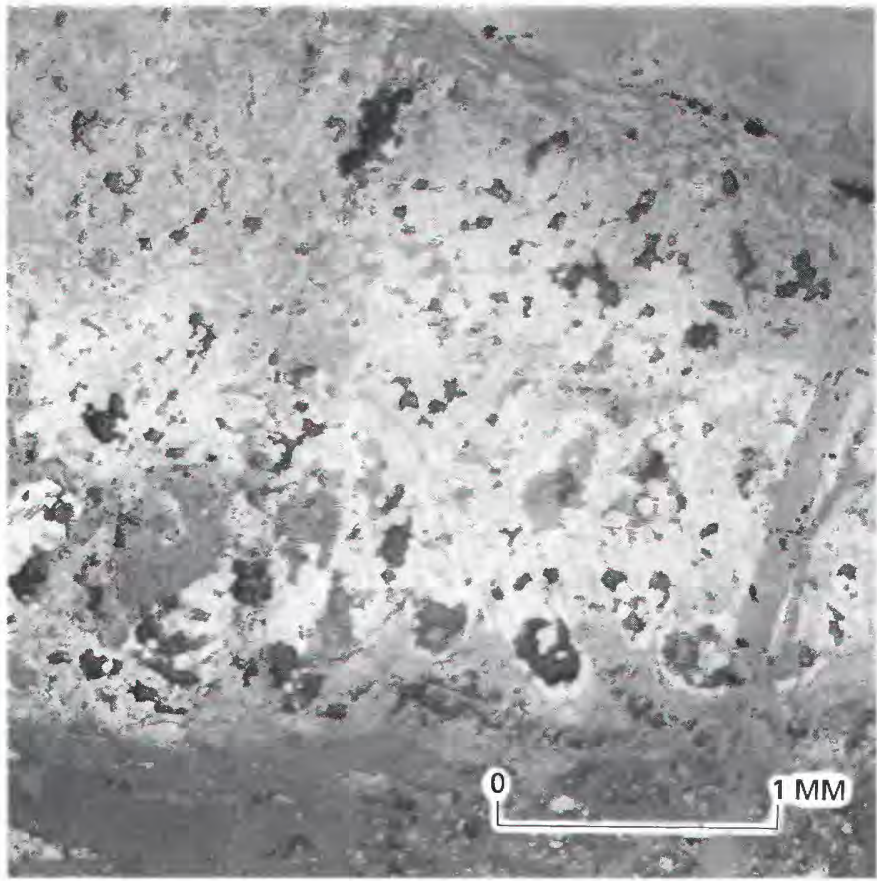

E

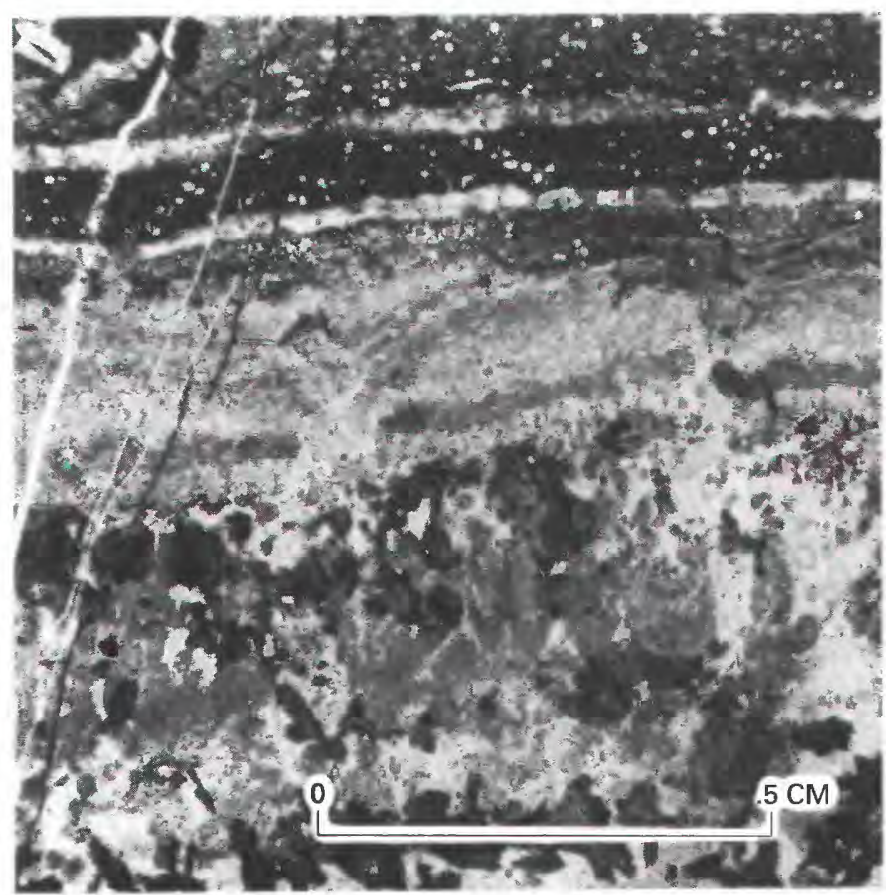

D

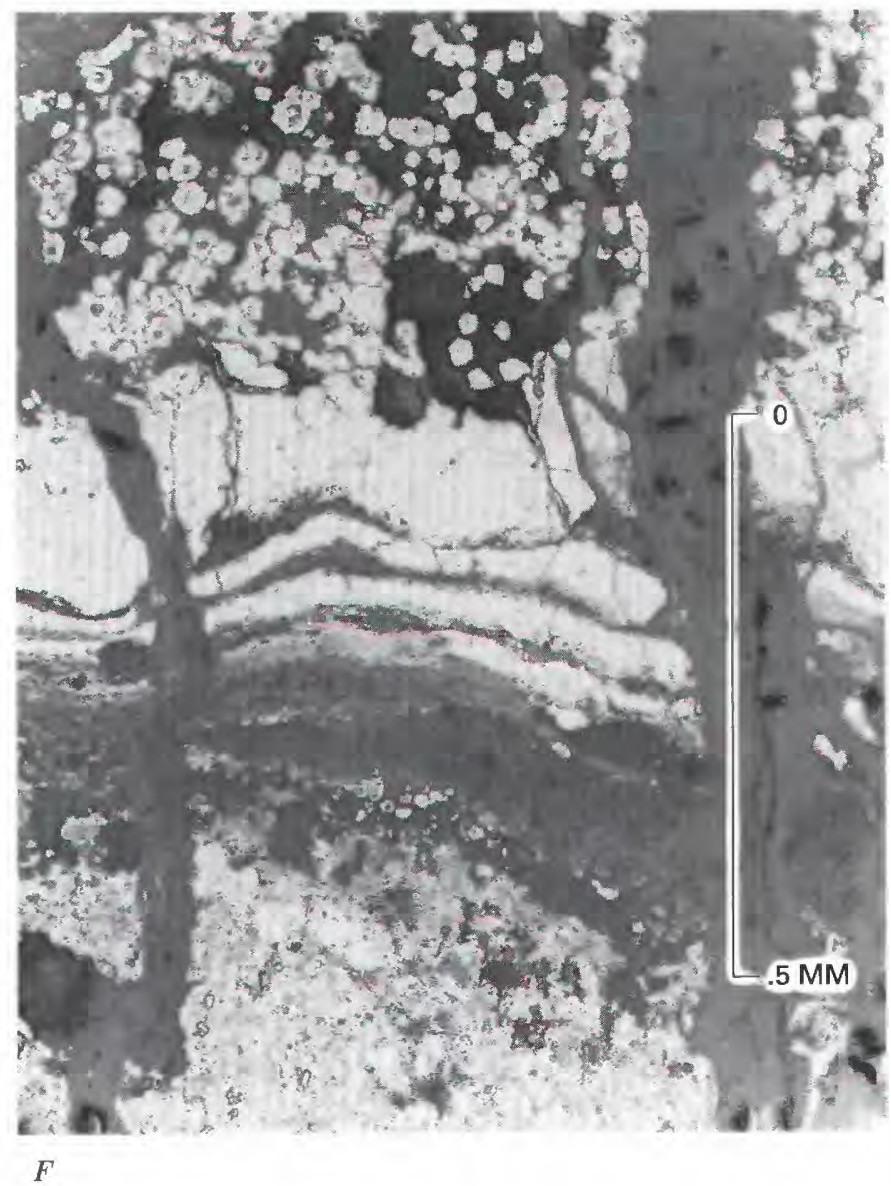




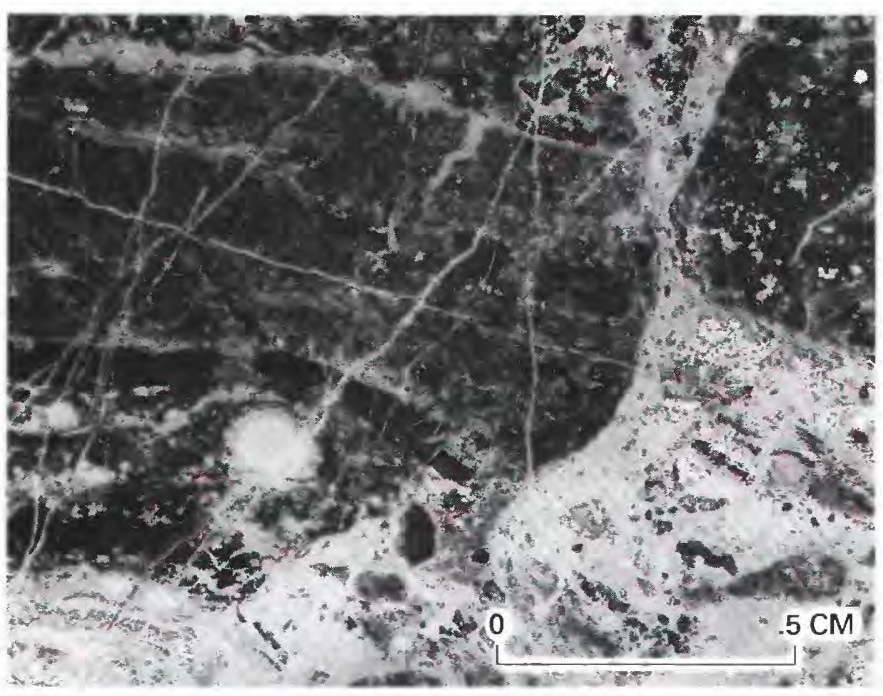

A

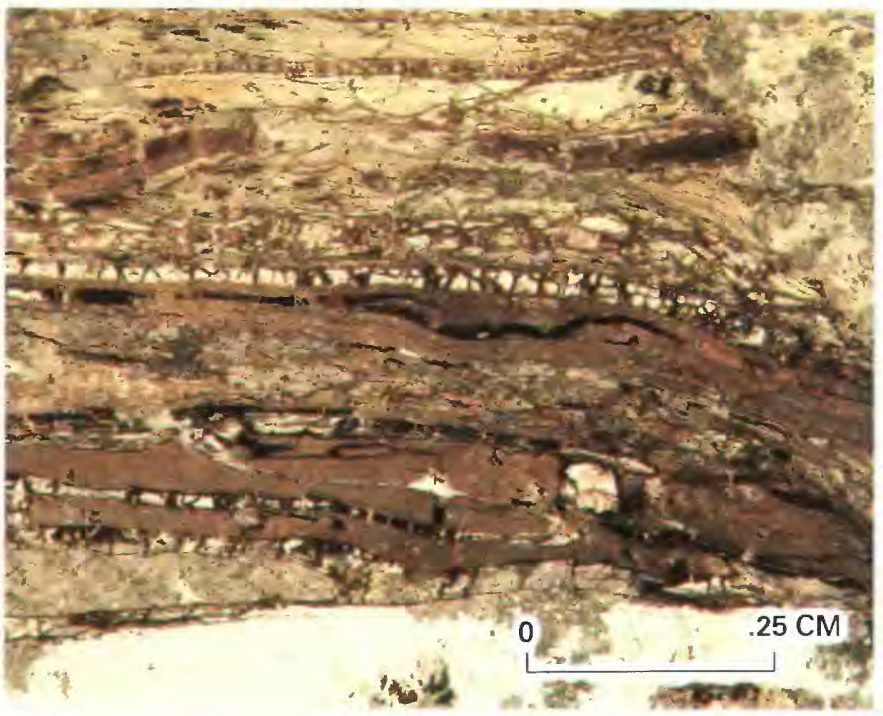

C

FIGURE 6.-Gel-like and partly recrystallized materials from the Buckeye deposit, California. A, B71b. Braunite (top) and fragments of gel-rich layers (bottom) displaced by fractures and engulfed in rhodochrosite. $B$, Enlargement of previous photograph. The fragments consist of clear, colorless, isotropic gel-like material (white; table 8, analysis 6) interlaminated with braunite (black) and rhodochrosite (gray). Mottling of the carbonate matrix is caused by admixed yellow gel-like material. Both gel-like materials have chlorite composition. $C, \mathrm{~B} 84$. Gel-like laminations (fig. $4 E$, top) having chlorite composition (white) interlayered with caryopilite (brown) and carbonate (brownish gray). Plane-polarized light. $D$, Detail under crossed nicols. The margins of the gel-like layer have been replaced by caryopilite and the interior of each layer has recrystallized to chlorite. $E$, B24. Fragment of pinkish (yellowish in photo-

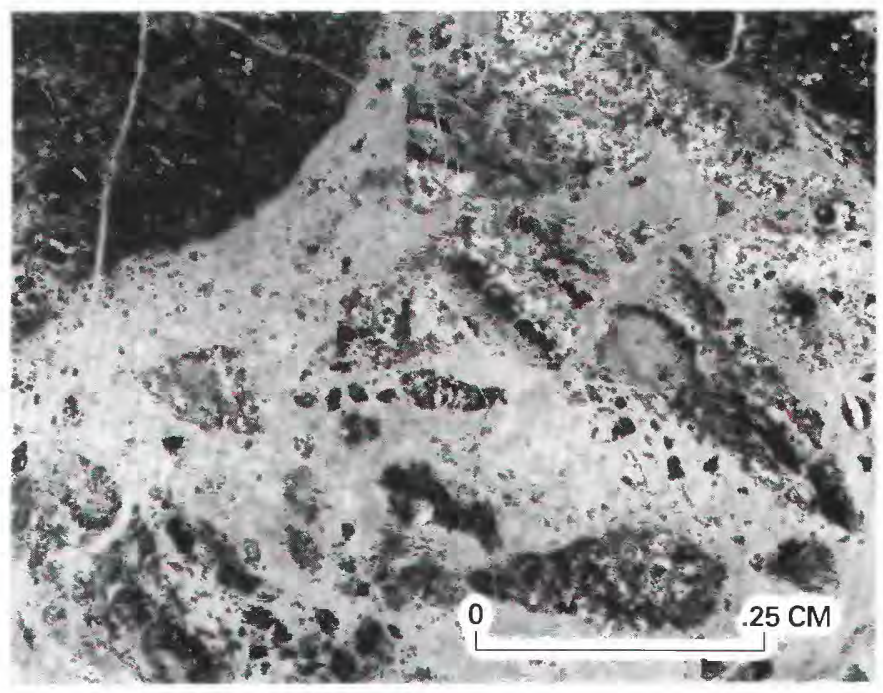

B

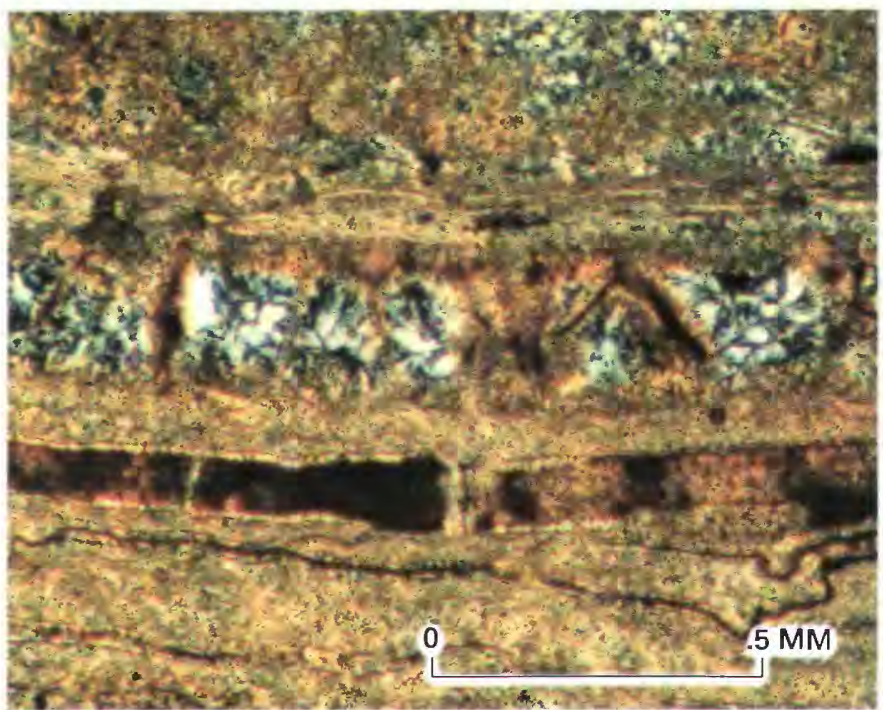

$D$

graph), transparent, gel-like layer (table 8, analysis 4), now surrounded by carbonate and taneyamalite. Plane-polarized light. $F$, Detail, crossed nicols. The gel-like material is slightly recrystallized to chlorite and contains tiny rhombohedra of rhodochrosite. G, B50. Residual pale-yellow gel-like material of chlorite composition (table 8, analysis 3) surrounded by gageite and rhodochrosite. Plane-polarized light. $H$, Same, crossed nicols. Gel-like material is isotropic. I, B80-4. Disrupted braunite layer with internal, curved (conchoidal), branching fractures. This shattered texture can be more easily explained by a process such as shrinkage or shock than by pervasive (external) shear deformation. Reflected light. $J$, B91. Rosettes of pale-yellow gageite growing against isotropic gel-like material of caryopilite composition (table 8, analysis 1 ) that contains crystals of braunite and rhodochrosite. 


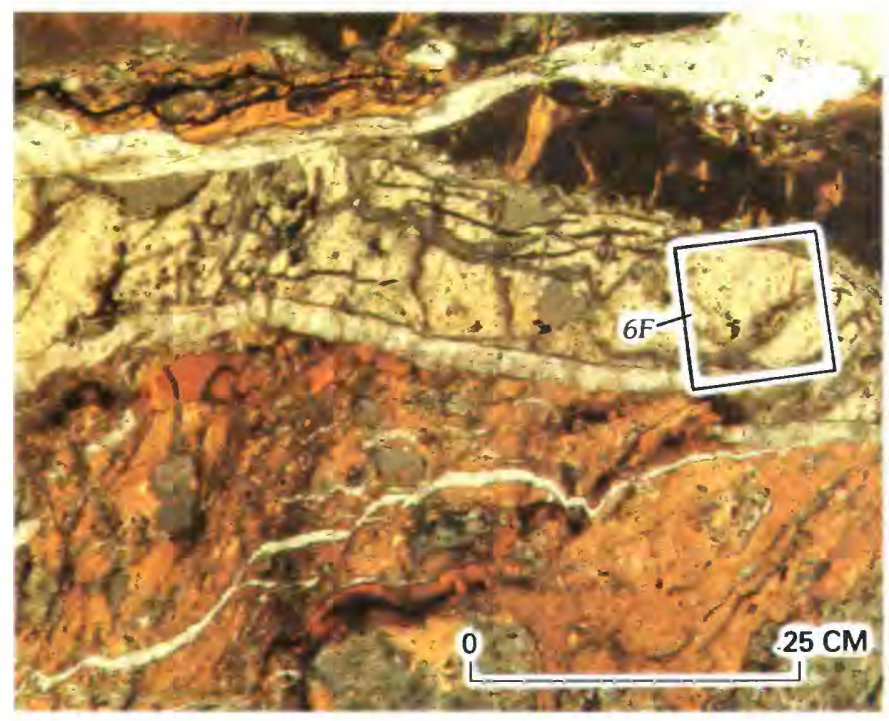

E
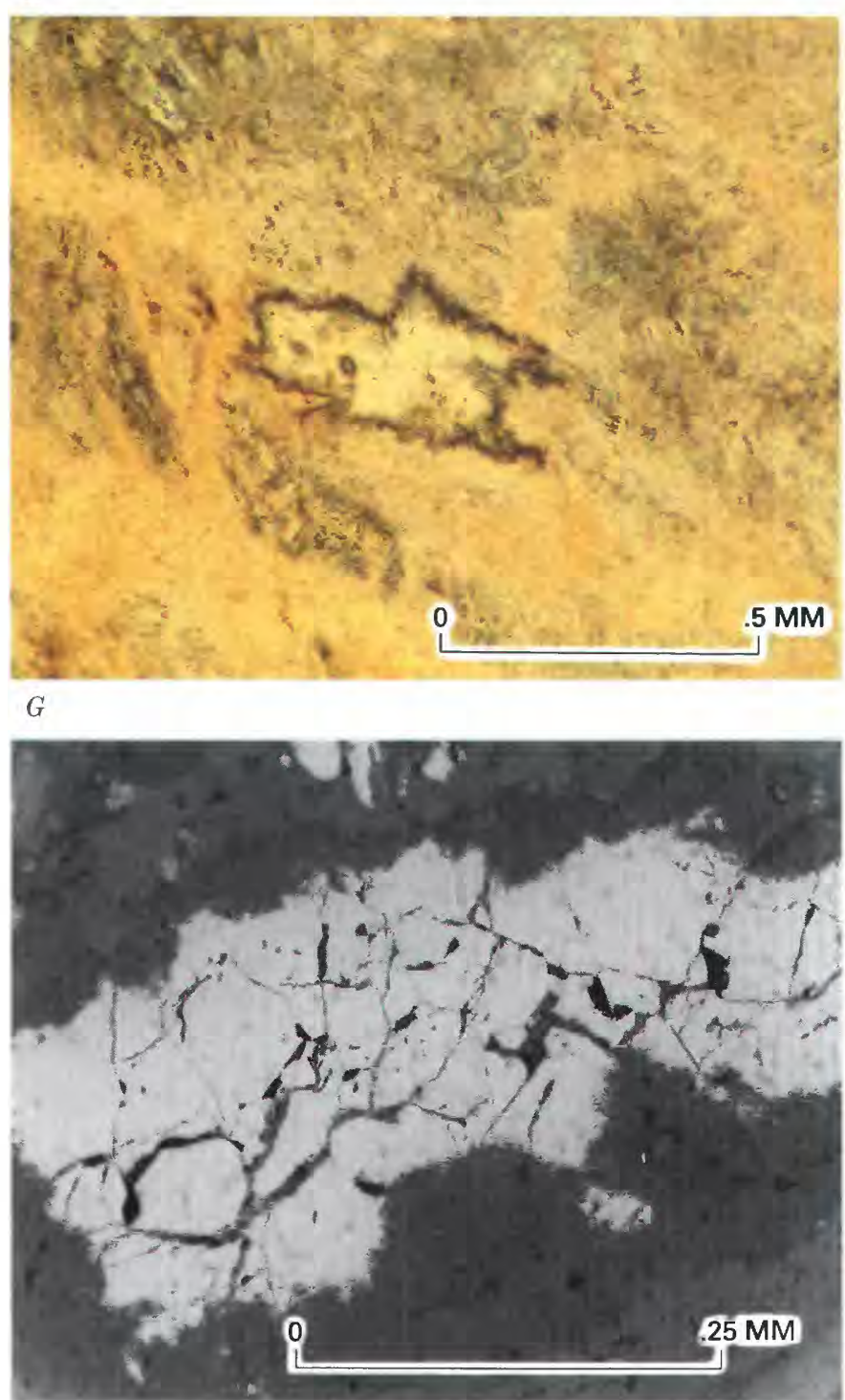
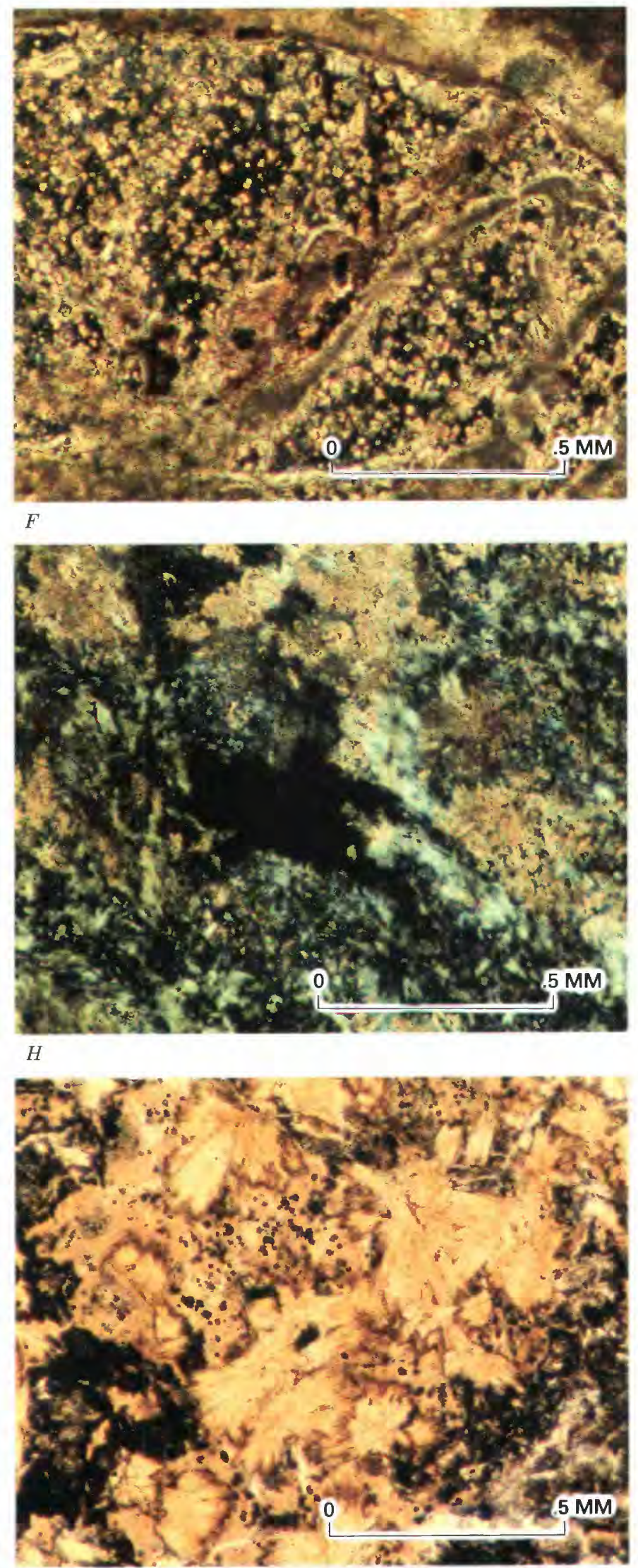


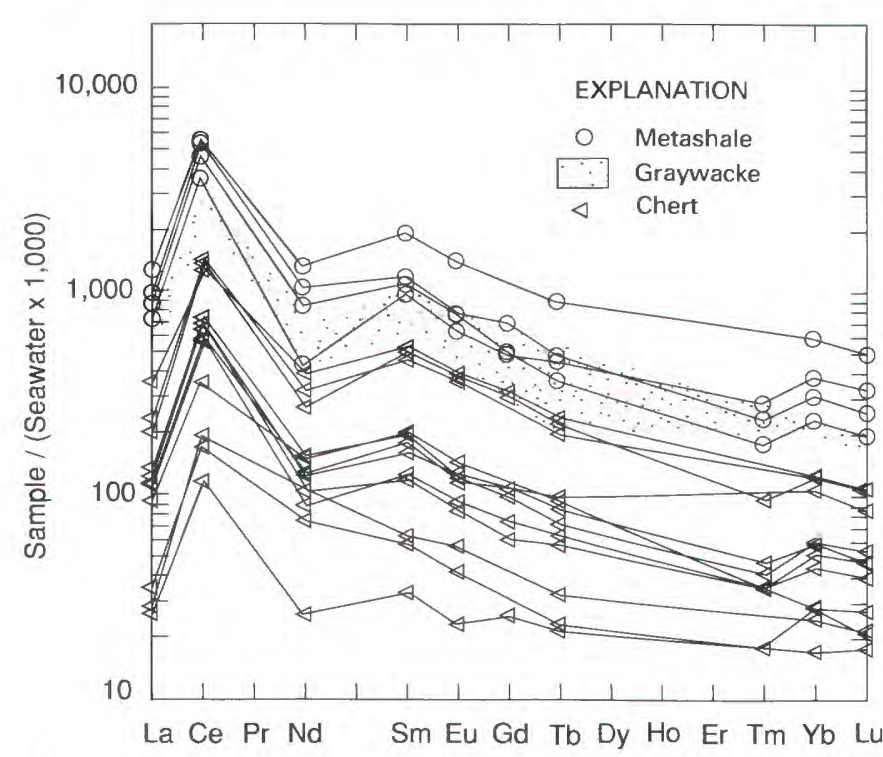

A

FiguRE 7. - Rare-earth-element (REE) patterns of country rock and ore from the Buckeye deposit, California, normalized to concentrations for seawater (Hogdahl and others, 1968). A, 4 metashales, the range for 7 graywackes, and 12 cherts. From Hein and others (1987, p. 218-219, Ladd-Buckeye district) and unpublished data for the Buckeye deposit by Huebner and Flohr. $B$, Mn-rich lithologies from the Buckeye deposit. Sample B104 is hausmannite rich, B84 is

ken formations), and B64 (quartz vein cutting pink recrystallized rhodochrosite; table 6). The REE abundances are enriched relative to seawater and other protoliths (fig. $7 B$ ). The Ce/La is 1.9 , and the Ce anomaly (relative to seawater) is very distinct.

\section{TANEYAMALITE}

Taneyamalite occurs as rare monomineralic layers conformable with laminations of caryopilite (B20, fig. $5 B)$, as two laminations interlayered with chlorite and carbonate (B38, fig. 8A), and as veins crossing bedding planes (B24; B29; B20, fig. $5 B$ ). We interpret the vein material as a soft sediment of taneyamalite composition that flowed during compaction from bedding laminations into veins, although taneyamalite is so uncommon that we are not absolutely certain that it represents a sediment composition. A resinous golden color in hand specimen, yellow color in thin section, and relatively high birefringence are indicators of the possible presence of taneyamalite. The XPD pattern is characteristic: the $(010),(-110),(-130),(-231),(032),(023)$, and (014, 4-23) reflections occur at $9.5^{\circ}, 11.0^{\circ}, 27.2^{\circ}, 32.0^{\circ}, 33.4^{\circ}$, $34.0^{\circ}$, and $40.6^{\circ}$, respectively. Insufficient pure material is available for a bulk analysis. Microprobe analyses indicate that taneyamalite is the most sodic manganiferous phase at the Buckeye.

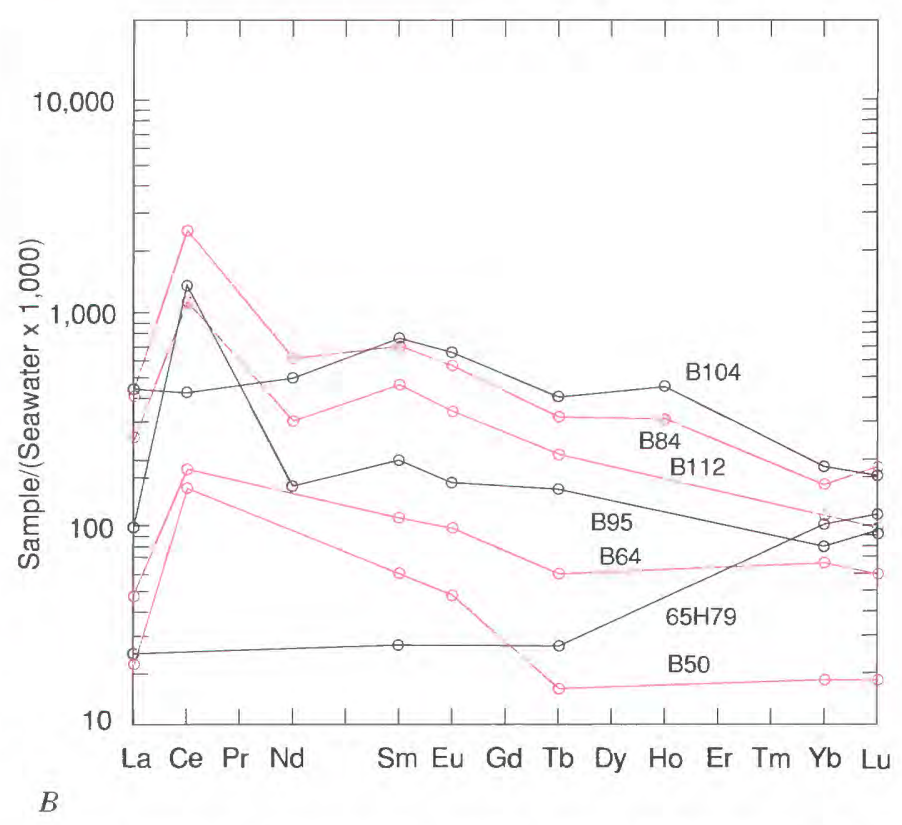

caryopilite rich, B112 is caryopilite and carbonate, B95 is braunite rich, $\mathrm{B} 64$ is a vein of pink recrystallized rhodochrosite and quartz, $65 \mathrm{H} 79$ is gageite, and B50 is unrecrystallized gray carbonate with gageite. The chemical analyses and mineral modes for these seven samples are given in table 6 and plotted in figure $9 D$. The range in REE contents of 17 additional Mn-rich protoliths (Huebner and Flohr, unpub. data) is comparable to that of the 7 samples plotted in this figure.

\section{CHLORITE PROTOLITH}

The chlorite protolith is represented by two textures: gel-like material, which occurs as thin laminae (B84, figs. $4 E, 6 C, D)$ or fragments of gel layers (B24, fig. $6 E, F$; $\mathrm{B} 57$; B71b, figs. $6 A, B)$, and massive layers of semioriented, clay-sized crystallites having, collectively, low birefringence (B11, B24, B25, B26, B31, B81a, 65H70). Texturally, gel-like material of chlorite composition dis-

Figure 8.-Minerals and textures of rocks from the Buckeye deposit, California, discussed in text. $A, B 38$. Interlaminated taneyamalite-phase A mixture (dark), chlorite (micaceous), and rhodochrosite (light gray) surrounded by caryopilite. $B, B 80$. Mass of recrystallized gel-like material (dark, near center) in the caryopilitechlorite mixture (mottled, medium gray). Note the rim of transparent caryopilite (white) adjacent to braunite layer (dark). $C$, B24. Coarsely crystallized caryopilite, relic gel-like material of chlorite composition, and a mixture of caryopilite, wispy chlorite, and relic gel-like material. The chlorite-rich composition of the gel-like material may be due to removal of $\mathrm{Mn}$ by crystallization of caryopilite from a gel-like material having initial chlorite-caryopilite composition. $D$, B91. Colorless to pale-yellow gageite rosettes (white to gray in photograph; table 9, analysis 2) in isotropic gel-like material of caryopilite composition (table 8 , analysis 1 ) with disseminated rhodochrosite rhombs. Crossed nicols; field of view is part of figure $6 J$. $E, \mathrm{~B} 24$. Bundles of radiating yellowish-orange fibers of phase A (table 9, analysis 10) in recrystallized rhodochrosite (lightest gray, table 11 , analysis 5 ) and chlorite (ch) (pale brown, table 8 , analysis 5). $F$, B6. Layers of braunite (massive) and of hausmannite idioblasts in carbonate. 


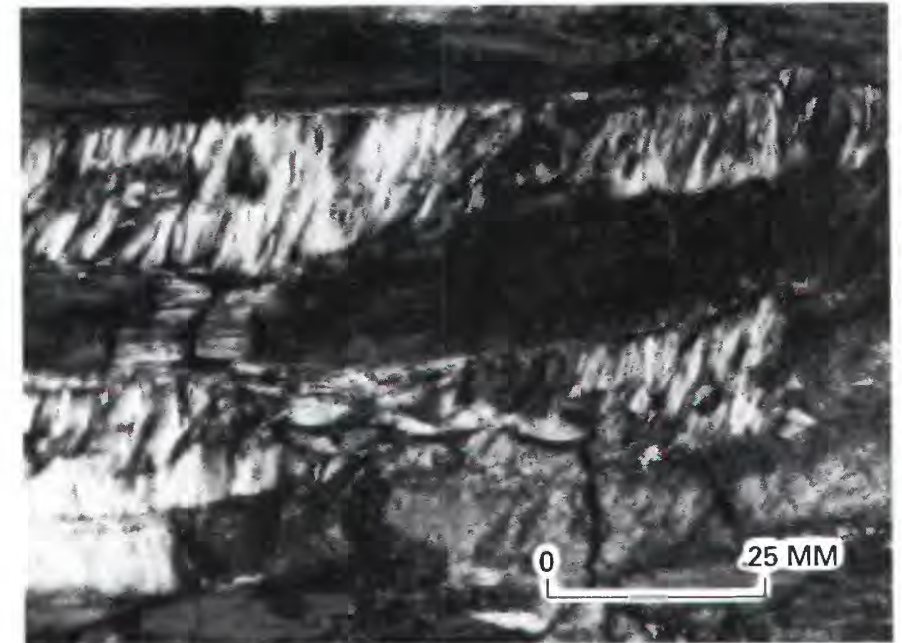

A

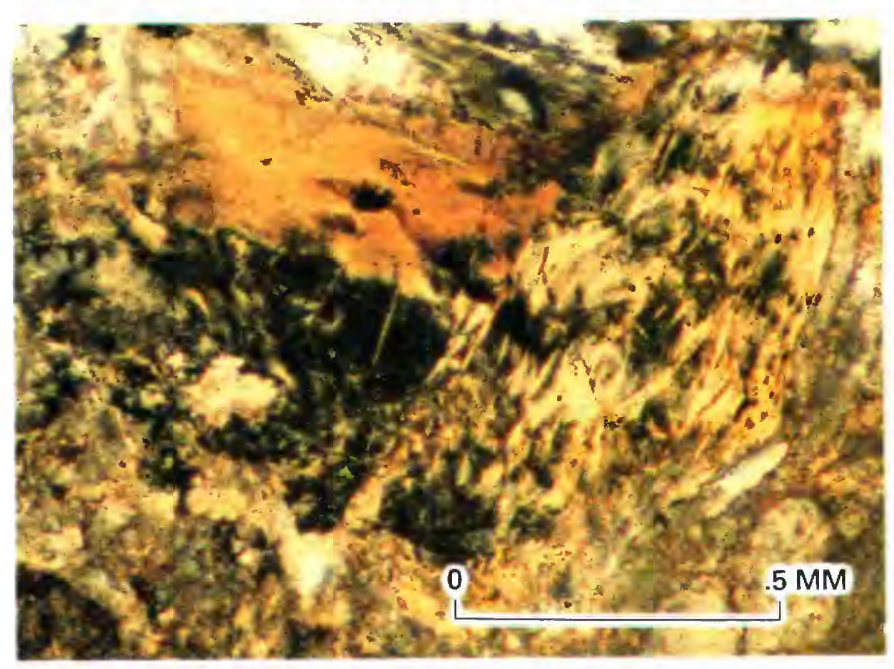

C

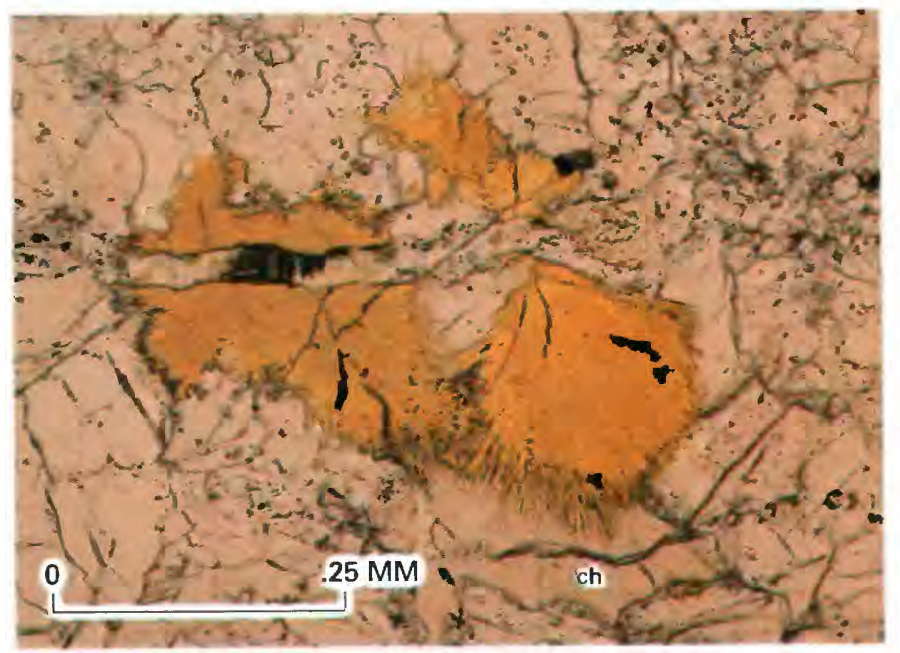

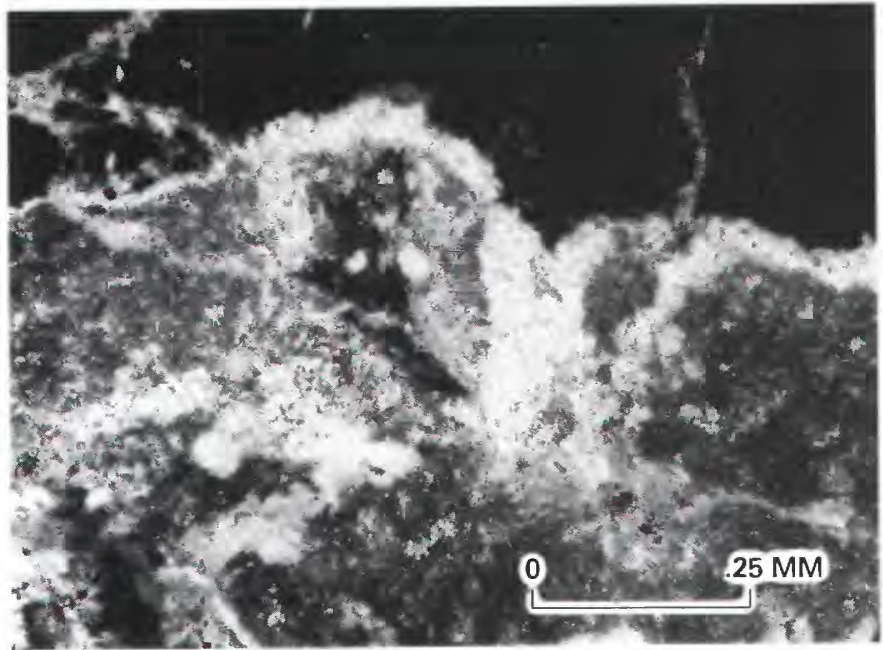

B

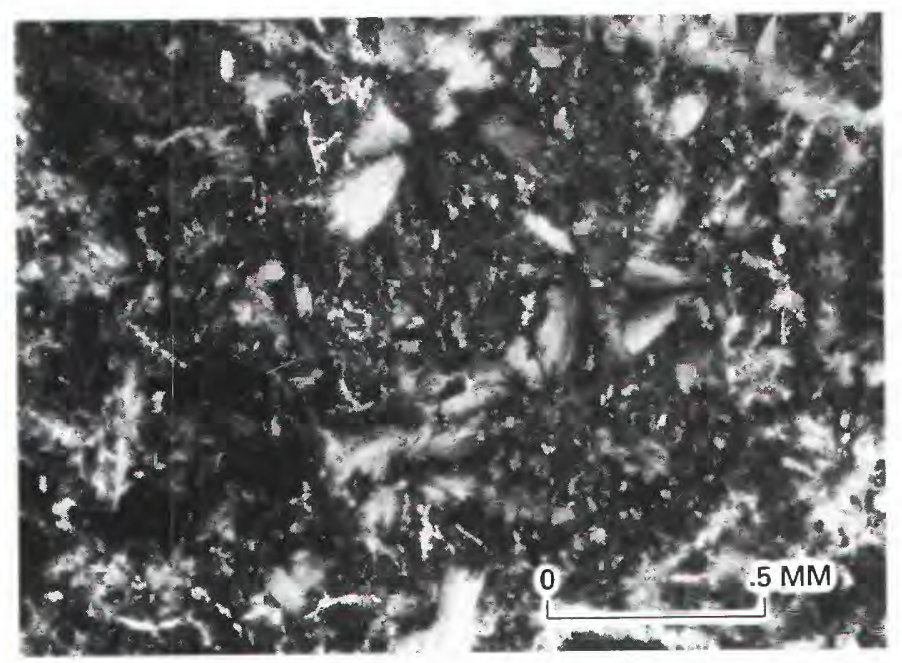

D

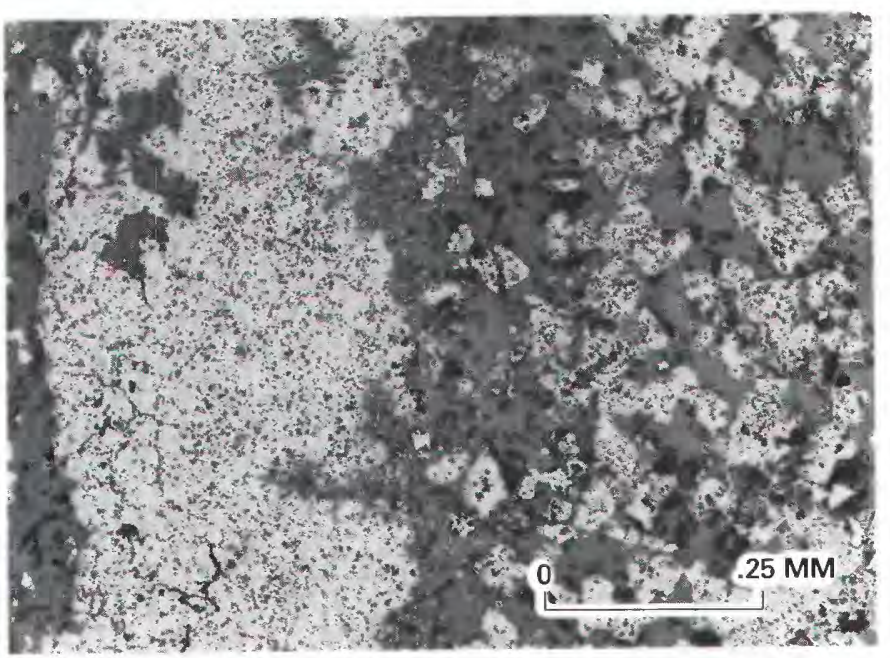


plays stages of "devitrification" that range from sensibly isotropic, through partially crystallized (wispy flakes of chlorite in residual gel-like material), to fully crystallized material with the characteristic anomalous low birefringence of chlorite. Commonly, gel-like material and recrystallized gel-like material of chlorite composition are clear in transmitted light, whereas claylike masses of chlorite composition are cloudy. The occurrence of the (001) X-ray reflection at $14.3^{\circ}$ is diagnostic of the presence of chlorite. Mechanically, the gel-like material appears to have fractured, forming curved surfaces (B24, $\mathrm{B} 71 \mathrm{~b})$, rather than to have flowed to surround fragments of other material. The chlorite laminations are too thin to be sampled for bulk chemistry.

\section{GAGEITE}

Gageite forms brownish-black laminations and layers, $0.5 \mathrm{~mm}$ to $1.5 \mathrm{~cm}$ thick, interlayered with hausmannite (B106; 65H79, fig. $4 B$ ), rhodochrosite, or mixtures of rhodochrosite and hausmannite (B45; B48; $65 \mathrm{H} 86$, fig. $4 H$ ). In thin section, the layers are opaque to dark red or dark brown and massive (granularity is not visible); orange to yellow anisotropic patches that appear fibrous are rare $(65 \mathrm{H} 79)$. X-ray diffraction reflections at $12.9^{\circ}$ $(200,020), 14.3^{\circ}(120), 26^{\circ}(400,040)$, and $27.5^{\circ}(330)$ and a broad reflection at $32.8^{\circ}$ are diagnostic. Gageite layers are commonly monomineralic, but in B106 some gageite laminations contain hausmannite idioblasts. Gel-like material of gageite composition does not occur, although some gageite is closely associated with residual gel-like material of chlorite composition. Thus, the nature of the gageite precursor is unknown. Gageite occurs both as broken layers in dismembered ore $(65 \mathrm{H} 86$, fig. $4 H)$ and as veinlets, apparently originating within a primary layer, intruding hausmannite protolith $(65 \mathrm{H} 79$, fig. $4 B)$. The mechanical behavior of the gageite protolith is intermediate between that of a fluid carbonate mud and that of the tougher hausmannite layers.

A 1-cm thick layer of gageite $(65 \mathrm{H} 79)$ appears monomineralic, but XPD results and the presence of 0.7 percent $\mathrm{CO}_{2}$ suggest contamination by surrounding hausmannite and carbonate, respectively (table 6 ). The chemistry of this sample is almost completely described by the system $\mathrm{MnO}-\mathrm{SiO}_{2}-\mathrm{H}_{2} \mathrm{O}$. Compared with other protoliths, gageite has the highest concentration of tungsten. Tungsten was detected only in samples that contained gageite, and the concentration of tungsten is roughly proportional to the amount of gageite in the mode (table 6). Gageite is also associated with relatively high values of $\mathrm{As}$ and $\mathrm{Ni}$. The gageite protolith has the most depleted light-REE abundances of all sediments, but the enrichment of heavy REE relative to light REE exceeds that of the other protoliths (fig. $7 B$ ). The Ce concentration is below the detection limit, preventing detection of a Ce anomaly, if present. Nevertheless, this REE pattern is most unusual. The only similar pattern of which we are aware was obtained from "Siliceous Mn-oxide ore" from the Ladd-Buckeye district (Hein and others, 1987, p. 218). Because Hein and others did not recognize gageite in any of their samples, we cannot verify that this unusual REE pattern is characteristic of gageite.

\section{HAUSMANNITE PROTOLITH}

Hausmannite forms well-developed crystals in thin coherent layers (B55; B56; B87, fig. 4A), in fractured layers (B53, 65H172), and dismembered layers (65H86, fig. $4 H$ ) and is disseminated in rhodochrosite layers (B106; B6, fig. 8F). In addition to its occurrence in sedimentary layers, hausmannite occurs as massive oxide (B104; $65 \mathrm{H} 79$, fig. $4 B$; $65 \mathrm{H} 171$ ) that is not obviously sedimentary and may represent the "hydrothermal" hausmannite of earlier workers. In all occurrences, the deep-red color in transmitted light and the deep-red internal reflections in reflected light, combined with the characteristic equant shape, pitted surfaces, and distinct anisotropy in reflected light, distinguish hausmannite from opaque braunite, deep-red gageite, and oxidized caryopilite. However, hausmannite from the Buckeye is not as extensively twinned as is hausmannite from rocks of higher metamorphic grade. The relative lack of twinning may reflect subsidence and deformation while the orebody was still a soft sediment; conversely, it may be due to the common occurrence of Buckeye hausmannite in easily deformed carbonate. Except when disseminated in rhodochrosite, the hausmannite fractures rather than flows. Hausmannite is responsible for X-ray reflections at $18.0^{\circ}, 29.0^{\circ}, 32.4^{\circ}, 36.1^{\circ}, 58.5^{\circ}$, and $59.9^{\circ}(101,112,103$, 211,321 , and 224 reflections, respectively), but its optical properties are so distinctive that it was not necessary to rely upon the characteristic X-ray reflections.

Massive hausmannite protolith (B104) containing carbonate and gageite impurities was analyzed (table 6). Considering that the mineralogy is basically that of an oxide, the $\mathrm{FeO}$ value of 0.19 percent is extraordinarily low. Hausmannite has the highest $\mathrm{Zn}$ concentration of all the protoliths analyzed, but no other trace-element concentration appears to be characteristic. The $30 \mathrm{ppm} \mathrm{W}$ reflects the presence of gageite in the sample. The REE abundances of $\mathrm{B} 104$ are enriched (fig. $7 B$ ), but the pattern is unusual. The Ce/La ratio is only 0.3 , resulting in a slightly negative $\mathrm{Ce}$ anomaly. The enrichment of the heavy $\mathrm{REE}$, relative to seawater, is greater than for any of the other Mn-rich protoliths. The lack of a Ce anomaly and the heavy-REE enrichment result in a pattern that is almost flat. 


\section{BRAUNITE PROTOLITH}

Braunite occurs as thin laminations $(10 \mu \mathrm{m})$ commonly grouped into layers (B71b, fig. $6 A$; B81, fig. $4 F$; B95, fig. $5 F$ ) that may be so closely spaced as to appear massive $(65 \mathrm{H} 19,65 \mathrm{H} 170)$. Opaque braunite layers range from poorly crystalline layers (lacking metallic reflectance but giving the characteristic braunite $\mathrm{X}$-ray reflections) to coarsely crystalline mosaics of anhedral crystals that exhibit the characteristic braunite anisotropy in shades of brownish gray. X-ray reflections at $33.0^{\circ}, 38.1^{\circ}$, and $55.3^{\circ}$ are characteristic. We found no braunite II (see De Villiers, 1980). Braunite is interlaminated with rhodochrosite, caryopilite, gageite, and, rarely, hausmannite. The coarsest crystals, 0.2 to $0.5 \mathrm{~mm}$ in size, invariably grow against carbonate at the margins of laminations. In their extent of deformation, the layers range from coherent through broken (B6; B81, fig. $4 F$ ) and dismembered (B53, B55) to a micromelange in which laminated braunite layers are engulfed in carbonate and give no indication of their original spatial relationships (B59). Braunite layers fractured into fragments, but protolith braunite was never observed to have flowed to surround fragments of another protolith. On a smaller scale, braunite layers contain many fractures that originate within, rather than pass completely through, the layers. Some braunite layers shattered such that the individual fragments are slightly separated but did not change their relative positions (B80, fig. 6I). This behavior suggests that braunite had gel-like mechanical properties. An unusual texture in which "toes" of coarsely crystallized braunite protrude into a mixture of rhodochrosite, chlorite, caryopilite, and fine-grained braunite (B95, fig. $5 E$ ) probably reflects the loss of fluids by passage through a braunite layer. This texture is similar to the dewatering texture in chert (fig. $5 D$ ) mentioned previously.

A braunite-rich protolith with carbonate, caryopilite, gageite, and chlorite as impurities was analyzed chemically (B95, table 6). The only major constituents (greater than 2 percent) are $\mathrm{Mn}, \mathrm{SiO}_{2}, \mathrm{CO}_{2}, \mathrm{H}_{2} \mathrm{O}$, and $\mathrm{Mg}$. This protolith has relatively high $\mathrm{Co}$ and $\mathrm{Ni}$ ( 26 and $840 \mathrm{ppm}$, respectively), but no other trace-element concentrations are characteristic. The $22 \mathrm{ppm} \mathrm{W}$ reflects admixed gageite. The REE abundances are higher than those in the carbonate (B50) and gageite (65H79) protoliths but lower than those in the caryopilite, graywacke, and metashales (fig. $7 B$ ). The $\mathrm{Ce} / \mathrm{La}$ is 4.4 and the $\mathrm{Ce}$ anomaly is very well developed. The contrast between the patterns for the hausmannite-rich and braunite-rich protoliths is striking. Because Ce has both trivalent and quadrivalent oxidation states, whereas La is exclusively trivalent, the variation in $\mathrm{Ce} / \mathrm{La}$ may indicate relative redox states during deposition of the protoliths, with the hausmannite protolith being deposited under more reducing conditions than the braunite protolith. This interpretation is consistent with the $\mathrm{Mn}^{+2} / \mathrm{Mn}^{+3}$ in these oxides.

\section{DIOPSIDIC ACMITE PROTOLITH}

In addition to the chert and metashale, a nonmanganiferous bed composed of extremely fine grained diopsidic acmite (B94, B96) occurs adjacent to braunite in the exploration adit that lies at approximately the same horizon as the south Buckeye orebody.

\section{SUMMARY OF PROTOLITHS}

Most Mn-rich samples from the Buckeye deposit contain relic layering, suggesting that the orebody was originally layered rather than massive, composed of interlaminated and interlayered sediments that are now represented by eight minerals. We believe that the surfaces bounding the laminations represent the original bedding planes, parallel to the sediment-seawater interface. While in a soft-sediment state, the more rigid, gel-like layers broke or fractured and the less competent muds flowed, resulting in internal structures that range from layered and laminated to massive. This range of structures is probably responsible for the conflicting descriptions of the ore by our predecessors. By this reasoning, their massive ore corresponds to our most intensely dismembered material. Because there is no clear evidence of bioturbation, the disruption and dismembering of layers probably is due to compaction or tectonism.

Organisms had a passive role in providing a detrital component (radiolaria). Direct evidence for either an active or passive role in precipitation of manganese is lacking, even though marine bacteria are known to oxidize and reduce manganese (Nealson, 1983). At a scale of 0.1 to $1 \mu \mathrm{m}$, we observed no oval structures that might be indicative of bacterial cell walls (Ghiorse and Hirsch, 1979) and no casts of bacterial or algal filaments encrusted with oxides (Alt, 1988) or sulfides and oxides (Jonasson and Walker, 1987). In contrast, Ostwald (1981) found fossil algal oncolites and probable coccoid bacteria in Cretaceous shallow-marine manganese ores from Groote Eylandt, Australia. On the basis of this finding and the existence of microorganisms that precipitate manganese oxides, he concluded that 10 - to $30-\mu \mathrm{m}$-thick laminations in manganiferous metashales have "organosedimentary structure" (p. 561-562). A recent report of delicate orange bacterial mats near low-temperature vents (Malahoff and others, 1987) is tantalizing, in part because the existence of such mats would be consistent with the lack of bioturbation, but we have no evidence to 
prove that the laminations in the protoliths at the Buckeye deposit are of organic origin.

Replacement textures such as islands of relic Mn-poor sediment in Mn-rich sediment, which would indicate introduction of manganese after deposition of sediment, were neither observed by us nor reported by earlier workers. Indeed, it is hard to imagine that the extremely fine-grained gel-like materials could survive manganese metasomatism without recrystallizing or that a laminated nonmanganiferous sediment could be replaced by the observed Mn-rich compositions while at the same time preserving the intricate laminations and developing the striking compositional contrast between layers. Thus, the manganese-rich nature of the orebody and the compositional contrast between laminations appear to be primary features, a conclusion similar to that reached years ago by Taliaferro and Hudson (1943, p. 272). All fibrous and sparry rhodochrosite, braunite, hausmannite, and fibrous brown $\mathrm{Mn}$-silicates observed by us are recrystallized primary sediments. These minerals are not diagnostic of postsedimentary hydrothermal or supergene activity, a view promulgated by Hewett (1972).

The Buckeye orebody is extraordinarily manganese rich; most protoliths can be described by the system $\mathrm{MnO}-\mathrm{SiO}_{2}-\mathrm{O}_{2}-\mathrm{CO}_{2}-\mathrm{H}_{2} \mathrm{O}$. Trace metals occur at much lower bulk concentrations than in many other marine manganese deposits, but the range of trace-element concentrations among protoliths is so large that the maximum values of some trace elements ( $\mathrm{Sc}, \mathrm{Cr}, \mathrm{V}, \mathrm{Mo}$, $\mathrm{Ba}, \mathrm{W}$ ) equal or exceed average values (Cronan, 1977) for some trace-element-rich ferromanganese crusts and nodules. The bulk chemistry of the orebody reflects processes that separated manganese from iron and sulfur with extreme efficiency. The complementary iron does not occur within the orebody or the surrounding envelope of massive chert. The metashales have high $\mathrm{Fe} / \mathrm{Mn}$ and may contain this iron complement, but we have not determined whether the metashales reflect an original detrital composition, contain a hydrothermal component, or are a residue (manganese was leached from the protolith of the metashale). The bed of diopsidic acmite is evidence that at least some iron-rich sediment was deposited adjacent to a manganese-rich sediment. No concentrations of sulfur (pyrite or other sulfide) were found, and the protoliths contain only trace quantities of iron and copper sulfides.

\section{MINERAL GHARAGTERIZATION AND CHEMISTRY}

Representative microprobe analyses are given in tables 8 to 12. These analyses and additional analyses are plotted in figure 9. Each plotted point represents either an average of three or more analyses of homogeneous phases (hausmannite, braunite, santaclaraite, parsettensite(?), talc, pennantite, clinopyroxene, smectite, phases A, B, C, D, and most rhodochrosite) or an individual spot-analysis of a heterogeneous phase (gageite, chlorite, caryopilite, some phase A) or mixture of phases (chloritecaryopilite, taneyamalite-phase A). (The nominal compositions of most of these phases are listed in table 1; phases A-D have not yet been identified as known mineral species and are discussed later.) Minerals present in thick laminations were initially identified optically and were confirmed by XPD. These identifications formed the basis for the initial selection of materials for microprobe analysis. Identification of layers that were too thin for routine sampling and XPD was problematic. Microprobe analyses of these laminations demonstrated that we could not rely upon optical techniques alone to identify the fine-grained phases. Thus, microprobe chemical analysis became an essential tool in routine mineral identification.

Manganiferous materials display textures ranging from gel-like through partially recrystallized gel-like material to crystalline material; from subcrystalline to granoblastic; and from massive and claylike to well foliated. Although this variety of textures is shown in the photographs, it is important to recognize that the diversity is largely due to overprints. The original sediments were gels, or gel-like materials, clay, and micrite.

\section{GEL-LIKE MATERIALS}

Our least recrystallized gel-like materials are colorless, pale yellow or pink, optically isotropic, and have compositions of sheet silicates (chlorite, caryopilite). The gel-like materials appear to be cohesive and to have fractured, rather than flowed, to form curved surfaces. Gel-like materials of varied compositions are known to form in other environments. Nahon and others (1982) described a colorless to straw-colored trioctahedral Mnrich smectite "plasma"; this material may be similar to our silicate gel-like materials. Hoffert and others (1978) found gel-like inclusions of $\mathrm{Mn}$-rich oxyhydroxides in Feand Si-rich marine sediments. These inclusions appeared to crystallize to rancieite and todorokite. Haggerty (1987; oral commun., 1987) reported dredging a nearly amorphous white mass with the consistency of petroleum jelly from a seamount in the Mariana forearc. This material contains $\mathrm{Mg}$ and $\mathrm{Si}$ but no $\mathrm{Al}$ and gave a very weak X-ray pattern similar to that of allophane. Brett and others (1987) reported the occurrence of gel with serpentine composition from the Juan de Fuca Ridge. Thus, there is precedent for the formation of silicate and oxide gel-like materials in recent geologic environments. 
TABLE 8.-Compositions of gel-like materials, in weight percent, from the Buckeye deposit, California Coast Ranges, determined by electron microprobe analysis

[Total $\mathrm{Fe}$ and $\mathrm{Mn}$ reported as $\mathrm{FeO}$ and $\mathrm{MnO}$, respectively. nd, not detected; na, not analyzed. $\mathrm{H}_{2} \mathrm{O}$ not determined, resulting in low oxide sums for caryopilite, caryopilite-chlorite, and chlorite]

\begin{tabular}{|c|c|c|c|c|c|c|c|c|c|}
\hline \multirow[b]{2}{*}{ Sample } & \multirow{2}{*}{$\frac{\text { Caryopilite }}{\text { B91 }}$} & \multirow{2}{*}{$\begin{array}{c}\text { Caryopilite- } \\
\text { Chlorite }\end{array}$} & \multicolumn{6}{|c|}{ Chlorite } & \multirow{2}{*}{$\frac{\text { Braunite }}{\mathrm{B} 80}$} \\
\hline & & & B50 & B24 & B24 & B71b & B80 & B48 & \\
\hline Column & 1 & 2 & 3 & 4 & 5 & 6 & 7 & 8 & 9 \\
\hline $\mathrm{SiO}_{2} \ldots \ldots \ldots \ldots \ldots \ldots \ldots \ldots$ & 37.2 & 33.8 & 29.5 & 31.1 & 36.2 & 36.4 & 34.7 & 33.9 & 10.4 \\
\hline $\mathrm{Al}_{2} \mathrm{O}_{3} \ldots \ldots \ldots \ldots \ldots \ldots \ldots \ldots \ldots \ldots$ & .95 & 11.7 & 17.7 & 17.2 & 12.9 & 14.0 & 13.9 & 14.0 & nd \\
\hline $\mathrm{TiO}_{2} \ldots$ & nd & nd & nd & nd & nd & nd & nd & nd & .36 \\
\hline $\mathrm{V}_{2} \mathrm{O}_{3} \ldots$ & nd & nd & nd & nd & nd & nd & nd & nd & nd \\
\hline MnO.... & 47.8 & 23.5 & 15.6 & 11.8 & 11.4 & 4.20 & 5.55 & 4.38 & 78.4 \\
\hline MgO..... & 2.90 & 16.5 & 23.8 & 24.0 & 23.6 & 28.8 & 31.0 & 33.3 & nd \\
\hline $\mathrm{FeO} \ldots \ldots \ldots \ldots \ldots \ldots \ldots \ldots \ldots \ldots \ldots$ & .40 & 2.39 & .83 & 1.53 & 3.01 & .39 & .20 & .20 & 3.20 \\
\hline $\mathrm{NiO} \ldots \ldots \ldots \ldots \ldots \ldots \ldots \ldots \ldots \ldots \ldots$ & .10 & .69 & .31 & 1.05 & 1.64 & .33 & .41 & 1.49 & nd \\
\hline$\ldots \ldots \ldots \ldots \ldots \ldots$ & .17 & .31 & nd & .33 & .77 & .67 & 1.12 & na & .11 \\
\hline $\mathrm{CaO} \ldots \ldots \ldots \ldots \ldots \ldots \ldots \ldots \ldots \ldots \ldots$ & nd & .05 & nd & .14 & .19 & .47 & .11 & nd & .48 \\
\hline $\mathrm{Na}_{2} \mathrm{O} \ldots \ldots \ldots \ldots \ldots \ldots \ldots \ldots \ldots \ldots$ & .04 & .04 & .04 & .05 & .08 & .11 & .13 & nd & nd \\
\hline Sum................... & 89.56 & 88.98 & 87.78 & 87.20 & 89.79 & 85.37 & 87.12 & 87.27 & 92.95 \\
\hline
\end{tabular}

1. Partly devitrified caryopilite with gageite laths (table 9 , analysis 2 ; fig. $8 D$ ); 4 points averaged.

2. Devitrified yellow mass within rhodochrosite (fig. $8 \mathrm{C}$ ); 9 points averaged.

3. Isotropic gel-like material within rhodochrosite layer (fig. $6 G, H) ; 3$ points averaged.

4. Pink, isotropic gel-like material; contains rhombs of rhodochrosite (fig. $6 E, F^{\prime}$ ); 4 points averaged.

5. Partly devitrified gel-like material with phase A (table 9 , analysis 10 ); 3 points averaged.

6. Isotropic gel-like material with braunite (figs. $6 \mathrm{~A}, \mathrm{~B}$ ); 5 points averaged.

7. Partly devitrified gel-like material with anomalous deep blue birefringence and a high $\mathrm{Zn}$ content within layer of caryopilite; 3 points averaged.

8. Partly devitrified chlorite with high $\mathrm{Mg}$ and $\mathrm{Ni}$ found with gageite and rhodochrosite; 3 points averaged.

9. Layer of now-crystallized gel-like material (fig. $6 I$ ); 3 points averaged.

The preservation of gel-like materials from Jurassic or Cretaceous time was initially surprising to us but appears to be possible if metamorphism is at low temperatures and under dry conditions.

Various textures of gel-like materials are shown in figure 6 , and representative compositions are given in table 8. Most well-preserved gel-like materials have chlorite composition with variable concentrations of magnesium and minor elements (table 8, analyses 3-8); one isotropic gel-like material has caryopilite composition (table 8, analysis 1). A nearly isotropic fragment of very pale yellow gel-like material, removed from a thin section of B57, gave a strong X-ray powder diffraction pattern of chlorite. Isotropic gel-like material of chlorite composition occurs as fragments (fig. $6 E$, table 8 , analysis 4 ; fig. $6 B$, table 8 , analysis 6 ) and as residues within gageite and rhodochrosite (figs. $6 G, H$, table 8 , analysis 3 ). Note the similarity between the texture of this residue and the texture of the dismembered carbonate protolith (fig. $5 \mathrm{~A}$ ). Commonly, gel-like material having chlorite composition is partly recrystallized, and sometimes it occurs with gageite (table 8 , analysis 8 ), caryopilite (fig. $8 B$, table 8 , analysis 7), or braunite (fig. $6 B$, table 8 , analysis 6 ). Totally isotropic material with a gageite composition has not yet been found. However, the materials from which gageite has crystallized have residues depleted in gageite component (figs. $6 G, H$, table 8 , analysis 3 ). In addition to rare isotropic gel-like material of caryopilite composition (fig. $8 D$, table 8 , analysis 1 ), disrupted layers and fragments of layers with a partly devitrified to wispy texture yield compositions between those of caryopilite and chlorite (fig. $8 C$, table 8 , analysis 2 ). A further indication that some caryopilite originally was a gel-like material is the occurrence of remarkably transparent yet anisotropic caryopilite layers in B20 (fig. $5 B$ ). Evidence that braunite layers were originally deposited as gel-like materials is the shattered texture due to curved and branching fractures that are confined to a braunite layer. This texture is probably caused by partial dehydration and shrinkage (fig. $6 I$, table 8 , analysis 9 ) or by tectonically induced shock.

The compositions of individual silicate species are not uniform, even within a single sample or layer, indicating that equilibration between the silicates (and between silicates, oxides, and carbonate, as discussed below) did not occur. In part, the range of compositions is attributed to very fine scale mixing of two silicates, which cannot be resolved with the microscope or the microprobe (fig. 9); the silicates also occur as monomineralic material within the same sample. In some cases, the actual end-member composition cannot be defined, making difficult the distinction between a single phase and a mixture. 
TABLE 11.-Compositions of rhodochrosite from the Buckeye deposit, California Coast Ranges, determined by electron microprobe analysis [All carbonates also analyzed for $\mathrm{Sr}, \mathrm{Ba}, \mathrm{Zn}, \mathrm{Ni}$, and $\mathrm{V}$, but these elements were not detected. $\mathrm{CO}_{2}$ calculated from stoichiometry, assuming $\mathrm{C}=1.000$. nd, not detected]

\begin{tabular}{|c|c|c|c|c|c|c|}
\hline $\begin{array}{l}\text { Sample } \\
\text { Column }\end{array}$ & $\begin{array}{c}\text { B45b } \\
1\end{array}$ & $\begin{array}{c}\text { B53 } \\
2\end{array}$ & $\begin{array}{c}\text { B53 } \\
3\end{array}$ & $\begin{array}{c}\mathrm{B} 6 \\
4\end{array}$ & $\begin{array}{c}\text { B24 } \\
5\end{array}$ & $\begin{array}{c}\text { B53 } \\
6\end{array}$ \\
\hline \multicolumn{7}{|c|}{ Oxides, in weight percent } \\
\hline Mno . & 59.6 & 56.9 & 57.4 & 57.5 & 53.3 & 52.7 \\
\hline $\mathrm{MgO}$. & 1.17 & 2.19 & 1.21 & 1.51 & .41 & .74 \\
\hline $\mathrm{CaO}$. & .13 & 1.78 & 2.34 & 1.68 & 5.80 & 6.89 \\
\hline FeO... & .11 & .09 & .08 & .09 & .46 & .08 \\
\hline Subsum .... & 61.01 & 60.96 & 61.03 & 60.78 & 59.97 & 60.41 \\
\hline $\mathrm{CO}_{2} \ldots$ & 38.64 & 39.10 & 38.88 & 38.90 & 39.00 & 39.21 \\
\hline Sum $\ldots \ldots$ & 99.65 & 100.06 & 99.91 & 99.68 & 98.97 & 99.62 \\
\hline
\end{tabular}

\begin{tabular}{lrrrrrr}
\hline \multicolumn{7}{c}{ Number of cations per formula unit } \\
\hline $\mathrm{Mn} \ldots \ldots \ldots \ldots \ldots$ & 0.962 & 0.902 & 0.917 & 0.922 & 0.862 & 0.839 \\
$\mathrm{Mg} \ldots \ldots \ldots \ldots \ldots$ & .033 & .061 & .034 & .043 & .012 & .021 \\
$\mathrm{Ca} \ldots \ldots \ldots \ldots \ldots$ & .003 & .036 & .047 & .034 & .119 & .139 \\
$\mathrm{Fe} \ldots \ldots \ldots \ldots \ldots$ & .002 & .001 & .001 & .001 & .007 & .001 \\
$\mathrm{C} \ldots \ldots \ldots \ldots \ldots$ & 1.000 & 1.000 & 1.000 & 1.000 & 1.000 & 1.000 \\
\cline { 2 - 7 } Cation sum ..... & 2.000 & 2.000 & 1.999 & 2.000 & 2.000 & 2.000
\end{tabular}

1. Coarsest grained rhodochrosite from rhodochrosite protolith (fig. $5 A$ ); 4 points averaged.

2. Rim of coarse-grained rhodochrosite in contact with braunite (table 12 , analysis 1); 3 points averaged.

3. Core of same coarse-grained rhodochrosite; 3 points averaged.

4. Fine-grained rhodochrosite with hausmannite (table 12 , analysis 5 ; fig. $8 F$ ); 4 points averaged.

5. Coarse rhodochrosite with phase A (table 9 , analysis 10 ; fig. $8 E$ ); 3 points averaged.

6. Rhodochrosite vein cutting braunite; 3 points averaged.

chlorite, the composition range of gageite is very small. No consistent correlation of composition with color, texture, or associated minerals was found. The greatest range in composition was found in samples $65 \mathrm{H} 79$ and $65 \mathrm{H} 86$. The observed color differences may be due to variable amounts of $\mathrm{Mn}$ in other than the +2 oxidation state. There is a good inverse correlation between $\mathrm{Mn}$ and $\mathrm{Si}+\mathrm{Mg}$ (table 9, analyses 1-4). Small amounts of nickel (up to 0.5 weight percent $\mathrm{NiO}$ ) were detected in most gageite.

Chemical formulas obtained for gageite from the Buckeye are inconsistent with those reported by Moore (1969), Dunn (1979), and Ferraris and others (1987) for gageite from other localities. The crystal structure of gageite described by Moore (1969) consists of walls of edge-sharing octahedra corner-linked to bundles of edgesharing octahedra. Silicate tetrahedra reside in pipes or channels and support the framework structure by a network of oxygen bonds. Moore proposed $\mathrm{M}_{42}\left(\mathrm{Si}_{12} \mathrm{O}_{36}\right)$ $\left[\mathrm{O}_{6}(\mathrm{OH})_{48}\right]$ as the formula, where $\mathrm{M}$ represents the divalent cations $\mathrm{Mn}, \mathrm{Mg}$, and $\mathrm{Zn}$, and $\mathrm{M} / \mathrm{Si}=3.50$. Ferraris and others (1987), using electron diffraction and transmission electron microscopy, confirmed the general octahedral structure but found that the distribution of the silicate tetrahedra within the channels was not consistent with the crystal-chemical model of Moore. They found two kinds of interlinked modules built by chains of edge-sharing octahedra and proposed $\mathrm{M}_{42} \mathrm{O}_{6}$ $(\mathrm{OH})_{40}\left(\mathrm{Si}_{4} \mathrm{O}_{12}\right)_{4}$ with $\mathrm{M} / \mathrm{Si}=2.625$ as the formula for gageite. Dunn (1979) analyzed gageite from Franklin, N.J., and proposed the empirical formula $\mathrm{M}_{40} \mathrm{Si}_{15} \mathrm{O}_{50}$ $(\mathrm{OH})_{40}$ with $\mathrm{M} / \mathrm{Si}=2.67$. In the analyses by Dunn, $\mathrm{M} / \mathrm{Si}$ ranges from 2.63 to 2.74. Significant $\mathrm{ZnO}$ and $\mathrm{MgO}$ (3.8-5.2 weight percent and 10.1-12.9 weight percent, respectively) were also present, leading to the suggestion that $\mathrm{Zn}$ and $\mathrm{Mg}$ are essential constituents. Unlike gageite analyzed by Dunn (1979), gageite from the Buckeye contains little or no $\mathrm{Zn}$, and there is only minor substitution of $\mathrm{Mg}$ for $\mathrm{Mn}$, indicating that $\mathrm{Zn}$ and $\mathrm{Mg}$ are not essential structural constituents. Most Buckeye gageite has $\mathrm{M} / \mathrm{Si}$ or $\mathrm{M} /(\mathrm{Si}+\mathrm{Al})$ of about 2.49 to 2.55 , outside of the range of the analyses of Dunn (1979) and consistent with the formula $\mathrm{M}_{5}(\mathrm{Si}, \mathrm{Al})_{2} \mathrm{O}_{(9-\mathrm{x})}(\mathrm{OH})_{2 \mathrm{x}}$ (ideal $\mathrm{M} / \mathrm{Si}=2.50$ ). Because of scatter in our data, some analyses are consistent with the formula of Dunn (1979) and others are inconsistent with any of the discussed formulae. The best agreement with our empirically derived formula ( $\mathrm{M}: \mathrm{Si}=5: 2)$ is obtained when there are 4.5 to $4.9 \mathrm{Mn}$ cations per 9 anions; as Mn decreases from 4.5 to 4.1 cations, $\mathrm{Si}$ increases to about 2.2 and $\mathrm{M} / \mathrm{Si}$ decreases to about 2.11. In a few analyses with fewer than $3.9 \mathrm{Mn}$ cations, Si decreases with decreasing manganese content. We do not know whether the trace amounts of tungsten in gageite-bearing protoliths occur in gageite or another phase.

Despite the extreme color variation-from almost transparent and colorless, through deep red or brown, to opaque in thin section-we found no relationship between gageite composition and color. A possible explanation relates to the intense absorption of the $\mathrm{Mn}^{+3}$ ion, which dominates the $\mathrm{Mn}^{+2}$ ion in spectra of oxides. Thus, even minute amounts of $\mathrm{Mn}^{+3}$ ion would color the gageite, yet we would not be able to see any difference in gageite composition by electron microprobe techniques. The occurrence of gageite supports this explanation: the centers of gageite septa (deformed protolith layers) tend to be intensely colored, whereas gageite laths growing into gel-like material or against carbonate tend to be almost colorless. We initially thought that dark color in gageite was due to supergene oxidation by fluids that followed gageite veins and did not alter the enclosing rhodochrosite. However, we observed that pieces of carbonate, left on the surface for 20 years, developed a black oxide rind even in the dry environment of the Diablo Range. Thus, in the absence of any other evidence of supergene alteration, such as alteration of the carbonate immediately adjacent to the gageite, we propose 
TABLE 12.-Compositions of the oxides braunite (columns 1-4) and hausmannite (columns 5-8) from the Buckeye deposit, California Coast Ranges, determined by electron microprobe analysis

[nd, not detected; na, not analyzed. $\mathrm{MnO}, \mathrm{Mn}_{2} \mathrm{O}_{3}, \mathrm{FeO}, \mathrm{Fe}_{2} \mathrm{O}_{3}, \mathrm{Mn}^{+3}, \mathrm{Mn}^{+2}, \mathrm{Fe}^{+3}, \mathrm{Fe}^{+2}$ calculated by assuming ideal stoichiometry of 8 cations per 12 anions for braunite and 3 cations per 4 anions for hausmannite]

\begin{tabular}{|c|c|c|c|c|c|c|c|c|}
\hline Sample & B53 & B53 & B6 & $65 \mathrm{H} 170$ & B6 & B106 & $65 \mathrm{H} 79$ & $65 \mathrm{H} 170$ \\
\hline Column & 1 & 2 & 3 & 4 & 5 & 6 & 7 & 8 \\
\hline \multicolumn{9}{|c|}{ Oxides, in weight percent } \\
\hline $\mathrm{SiO}_{2} \ldots \ldots \ldots \ldots \ldots$ & 9.79 & 9.88 & 9.87 & 10.0 & 0.22 & nd & nd & nd \\
\hline $\mathrm{TiO}_{2} \ldots \ldots \ldots \ldots$ & nd & nd & nd & nd & .05 & nd & nd & nd \\
\hline $\mathrm{Mn}_{2} \mathrm{O}_{3} \ldots \ldots \ldots \ldots$ & 77.5 & 76.7 & 78.4 & 78.6 & 67.8 & 69.2 & 69.8 & 69.1 \\
\hline $\mathrm{Fe}_{2} \mathrm{O}_{3} \ldots \ldots \ldots \ldots \ldots$ & .23 & .51 & .47 & .24 & .480 & 0 & .21 & .40 \\
\hline $\mathrm{Al}_{2} \mathrm{O}_{3} \ldots \ldots \ldots \ldots \ldots$ & nd & nd & .27 & nd & nd & nd & nd & nd \\
\hline $\mathrm{Cr}_{2} \mathrm{O}_{3} \ldots \ldots \ldots \ldots \ldots$ & nd & nd & na & na & na & na & na & na \\
\hline $\mathrm{V}_{2} \mathrm{O}_{3} \ldots \ldots \ldots \ldots \ldots$ & nd & nd & nd & nd & .05 & .12 & .08 & nd \\
\hline MnO............... & 10.9 & 10.6 & 11.1 & 11.6 & 0 & 30.3 & 29.0 & 30.6 \\
\hline $\mathrm{FeO} \ldots \ldots \ldots \ldots \ldots$ & 0 & 0 & 0 & 0 & 0 & 0 & 0 & 0 \\
\hline MgO............... & .05 & .11 & .15 & nd & .03 & .36 & 1.33 & .46 \\
\hline $\mathrm{NiO}, \ldots \ldots \ldots \ldots \ldots$ & .14 & .33 & nd & nd & nd & .08 & .15 & nd \\
\hline $\mathrm{ZnO} \ldots \ldots \ldots \ldots \ldots$ & nd & nd & nd & nd & .07 & .09 & nd & nd \\
\hline $\mathrm{CoO} \ldots \ldots \ldots \ldots \ldots$ & nd & nd & nd & nd & nd & nd & nd & nd \\
\hline $\mathrm{CaO} \ldots \ldots \ldots \ldots \ldots$ & .34 & .40 & .18 & .15 & .07 & nd & nd & nd \\
\hline $\mathrm{BaO} \ldots \ldots \ldots \ldots \ldots$ & nd & .03 & nd & nd & nd & nd & nd & nd \\
\hline $\mathrm{Na}_{2} \mathrm{O} \ldots \ldots \ldots \ldots \ldots$ & nd & nd & nd & nd & nd & nd & nd & nd \\
\hline Sum... & 98.95 & 98.56 & 100.44 & 100.59 & 99.77 & 100.15 & 100.57 & 100.56 \\
\hline " $\mathrm{MnO}^{\prime} * \ldots \ldots$ & 80.52 & 79.59 & 81.63 & 82.19 & 91.89 & 92.56 & 91.71 & 92.74 \\
\hline "FeO"* $\ldots \ldots$ & .21 & .46 & .42 & .22 & .43 & nd & .19 & .36 \\
\hline \multicolumn{9}{|c|}{ Number of cations per formula unit } \\
\hline$\ldots \ldots \ldots \ldots \ldots$ & 0.995 & 1.006 & 0.985 & 1.000 & 0.008 & 0 & 0 & 0 \\
\hline $\mathrm{Ti} \ldots \ldots \ldots \ldots \ldots \ldots$ & 0 & 0 & 0 & 0 & .001 & 0 & 0 & 0 \\
\hline $\mathrm{Mn}^{+3} \ldots \ldots \ldots \ldots \ldots$ & 5.992 & 5.947 & 5.961 & 5.984 & 1.967 & 1.996 & 1.991 & 1.982 \\
\hline $\mathrm{Fe}^{+3} \ldots \ldots \ldots \ldots \ldots$ & .018 & .039 & .035 & .018 & .014 & 0 & .006 & .011 \\
\hline $\mathrm{Al}, \ldots \ldots \ldots \ldots \ldots$ & 0 & 0 & .032 & 0 & 0 & 0 & 0 & 0 \\
\hline Cr................. & 0 & 0 & 0 & 0 & 0 & 0 & 0 & 0 \\
\hline $\mathrm{V} \ldots \ldots \ldots \ldots \ldots$ & 0 & 0 & 0 & 0 & .002 & .004 & .002 & 0 \\
\hline$\ldots \ldots \ldots \ldots \ldots$ & .938 & .917 & .944 & .980 & 1.000 & .973 & .922 & .978 \\
\hline $\mathrm{Fe}^{+2} \ldots \ldots \ldots \ldots \ldots$ & 0 & 0 & 0 & 0 & 0 & 0 & 0 & 0 \\
\hline $\mathrm{Mg} \ldots \ldots \ldots \ldots \ldots$ & .008 & .017 & .022 & 0 & .002 & .020 & .074 & .026 \\
\hline Ni............... & .011 & .027 & 0 & 0 & 0 & .002 & .005 & 0 \\
\hline $\mathrm{Zn} \ldots \ldots \ldots \ldots \ldots$ & 0 & 0 & 0 & 0 & .002 & .003 & 0 & 0 \\
\hline $\mathrm{Co} \ldots \ldots \ldots \ldots \ldots$. & 0 & 0 & 0 & 0 & 0 & 0 & 0 & 0 \\
\hline $\mathrm{Ca} \ldots \ldots \ldots \ldots \ldots$ & .037 & .044 & .019 & .016 & .003 & 0 & 0 & 0 \\
\hline $\mathrm{Ba} \ldots \ldots \ldots \ldots \ldots$ & 0 & .001 & 0 & 0 & 0 & 0 & 0 & 0 \\
\hline $\mathrm{Na} \ldots \ldots \ldots \ldots \ldots$ & 0 & 0 & 0 & 0 & 0 & 0 & 0 & 0 \\
\hline Cation sum..... & 7.999 & 7.998 & 7.998 & 7.998 & 2.999 & 2.998 & 3.000 & 2.997 \\
\hline
\end{tabular}

\footnotetext{
* Total $\mathrm{Mn}$ as $\mathrm{MnO}$ and total $\mathrm{Fe}$ as $\mathrm{FeO}$, obtained by electron microprobe analysis.

1. Coarse-grained braunite rims in contact with rhodochrosite (table 11, analysis 2); 3 points averaged.

2. Fine-grained braunite with rhodochrosite in cores of grains (rim composition is given in this table, analysis 1); 3 points averaged.

3. Braunite coexisting with hausmannite (analysis 5 , this table; fig. $8 F$ ); 3 points averaged.

4. Braunite coexisting with hausmannite (analysis 8 , this table); 6 points averaged.

5. Hausmannite from hausmannite-braunite-rhodochrosite sample; 3 points averaged. Braunite is analysis 3 , this table.

6. Hausmannite from hausmannite-rhodochrosite sample; 6 points averaged.

7. Hausmannite layer within gageite; 3 points averaged.

8. Hausmannite coexisting with braunite (analysis 4 , this table); 3 points averaged.
}

instead that the intense coloration of the gageite protolith reflects its initial oxidation state and that the lightcolored marginal laths have inherited the (presumably) more reduced state of the adjacent carbonate and caryopilite protoliths.

\section{CARYOPILITE AND CHLORITE}

Caryopilite generally is orange or orange brown and contains about 0.1 weight percent each of $\mathrm{NiO}$ and $\mathrm{ZnO}$; the concentrations of $\mathrm{V}_{2} \mathrm{O}_{3}$ and $\mathrm{TiO}_{2}$ are generally below 


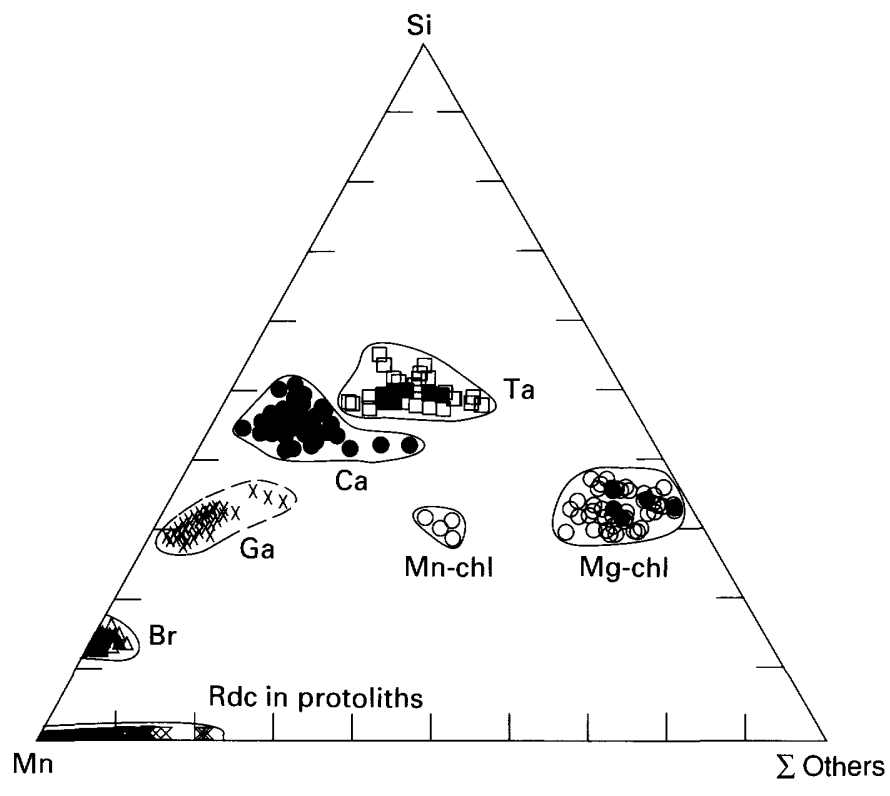

$A$

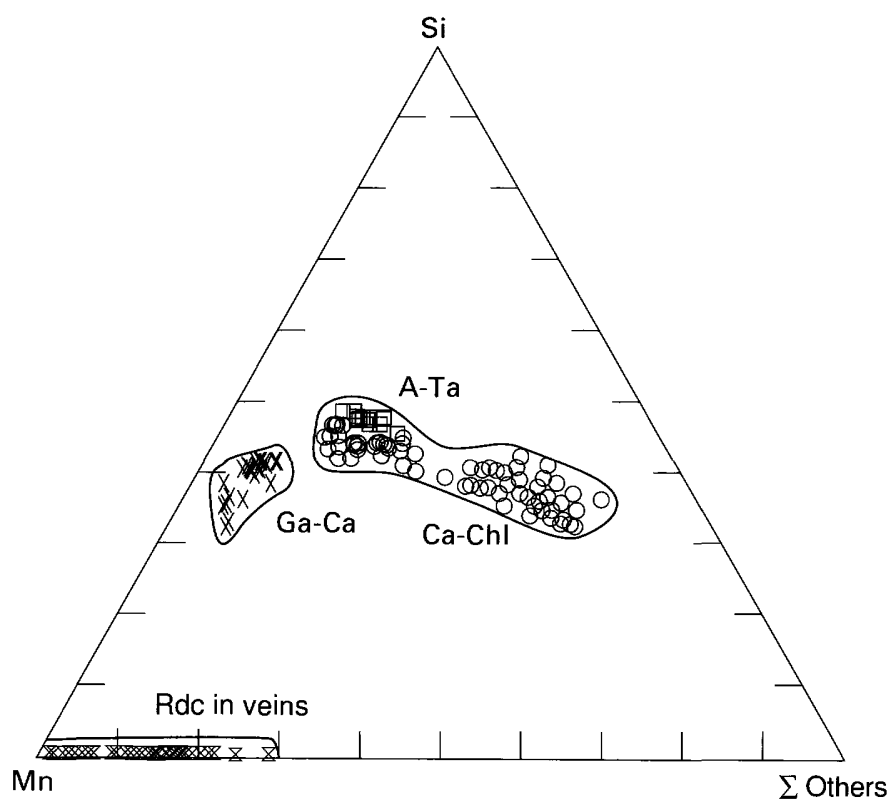

$C$

FIGURE 9. - Summary of chemical analyses of samples from the Buckeye deposit, California, plotted in the system Mn-Si-Others, where Others consists principally of the elements $\mathrm{Mg}, \mathrm{Al}, \mathrm{Fe}, \mathrm{V}, \mathrm{Ti}, \mathrm{Ni}, \mathrm{Zn}$, $\mathrm{Na}$, and $\mathrm{Ca}$. Cation proportions. $A$ and $B$, microprobe analyses of discrete phases; $C$, analyses of mixtures of phases, plus single-phase vein carbonates; $D$, bulk analyses of representative protoliths. The clustering of microprobe analyses does not represent the bulk composition of the deposit. Bulk analyses of protoliths fall near Mn on

the detection limits of the microprobe (table 9, analyses $5-7)$. The iron concentration is commonly less than 3 weight percent $\mathrm{FeO}$. The aluminum and magnesium concentrations of material with the appearance of caryopilite range from those of near endmember caryopilite
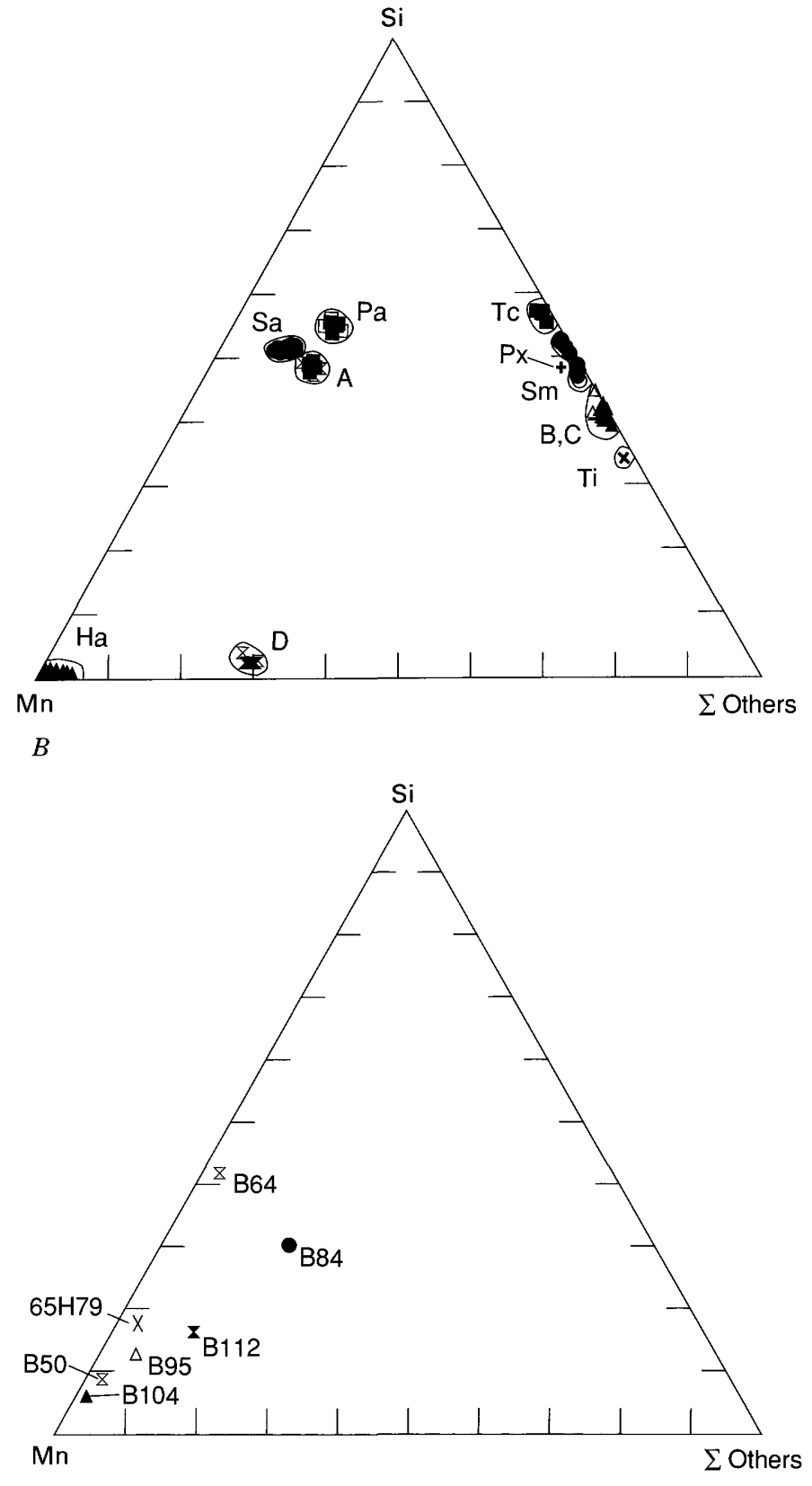

$D$

the Mn-Si join. Symbols: Ta, taneyamalite; Ca, caryopilite; Ga, gageite; $\mathrm{Br}$, braunite; $\mathrm{Mn}$-chl, $\mathrm{Mn}$-rich chlorite; $\mathrm{Mg}$-chl, $\mathrm{Mg}$-rich chlorite; Rdc, Mn-rich carbonates; $\mathrm{Pa}$, parsettensitelike mineral; Sa, santaclaraite; $\mathrm{A}, \mathrm{B}, \mathrm{C}$, and D, minerals designated phase A, B, C, and D; Tc, talc; Px, acmitic diopside; $\mathrm{Sm}$, smectite; Ti, titanite; $\mathrm{Ha}$, hausmannite. In $C$, squares represent analyses of phase A-taneyamalite mixtures, circles represent analyses of caryopilite-chlorite mixtures, and crosses represent analyses of gageite-caryopilite mixtures.

to those of near endmember clinochlore (fig. 9). It is probable that small amounts of $\mathrm{Mg}$ and $\mathrm{Fe}$ can substitute for $\mathrm{Mn}$ in caryopilite, and of $\mathrm{Mn}$ for $\mathrm{Mg}$ in chlorites, within the two structure types, but the fact that $\mathrm{Mg}$ is positively correlated with $\mathrm{Al}$ over much of the composi- 
tion range indicates that most of the compositional variation is due to mixing between these two phases. When Mg exceeds about 1 cation per 14 anions (about 5 weight percent $\mathrm{MgO}$ ) in caryopilite, the concentration of $\mathrm{Al}$ increases linearly with the $\mathrm{Mg}$, indicating that mixtures of caryopilite and chlorite have been analyzed. This is the composition limit separating caryopilite from mixtures of caryopilite-chlorite in figure 9. Mixtures of $\mathrm{Mg}$-chlorite and caryopilite trend toward two chlorite compositions, one with lower $\mathrm{Al}$ and higher $\mathrm{Mg}$ than the other (fig. 10). A few points identified as mixtures (fig. 10) with $\mathrm{Mg}$ less than 1 and about $0.5 \mathrm{Al}$ are from $\mathrm{B} 38$ and are slightly more Fe-rich than caryopilite analyzed from other samples. With the exception of sample B24, compositions within a given sample fall on only one trend. In B24, two distinct chlorite compositions are found, as discussed below. Rarely, caryopilite has high $\mathrm{Mg}$ (B17, table 9 , analysis 6 ; fig. 10 ) without correspondingly high $\mathrm{Al}$ and low $\mathrm{Si}$, suggesting that more than the arbitrary 5 weight percent $\mathrm{MgO}$ can substitute for $\mathrm{Mn}$ in the caryopilite structure (rather than being due to admixed chlorite or pennantite). These high $\mathrm{Mg}$ values cause the overlap between the caryopilite field and the mixed caryopilite-chlorite field (compare figs. 9B,C). Caryopilite also occurs with gageite. In addition to the discrete caryopilite and gageite, sample B95 contains deep-orange to deep-red material, suggestive of the color of gageite but with intermediate composition (fig. $9 \mathrm{C}$ ) attributed to intergrowths of caryopilite and gageite. B17 is similar, but with only a trace of mixed caryopilitegageite. B54 contains discrete caryopilite and the mixed material, but discrete gageite is absent.

Evaluation of microprobe analyses of caryopilite and determination of its composition limits are made even more difficult because caryopilite has a modulated structure (Guggenheim and Eggleton, 1987), which results in an excess of tetrahedrally coordinated cations and a deficiency of octahedral cations relative to the ideal serpentine formula unit, $\mathrm{Mg}_{6} \mathrm{Si}_{4} \mathrm{O}_{10}(\mathrm{OH})_{8}$. Caryopilite from the Buckeye deposits has octahedral/tetrahedral cation ratios of 1.23 to 1.32 , similar to but outside of the range of 1.36 to 1.44 found by Guggenheim and others (1982). The deficiency of octahedral cations in Buckeye caryopilite may in part be due to the relatively oxidized state of the orebody, causing substitution of $\mathrm{Fe}^{+3}$ or $\mathrm{Mn}^{+3}$ for $\mathrm{Fe}^{+2}$ or $\mathrm{Mn}^{+2}$ (thereby creating vacancies), or to admixed trioctahedral smectite.

An interesting textural relationship between caryopilite and layers of mixed caryopilite and chlorite is observed in sample B80 (fig. $8 B$ ). The sample is composed of disrupted layers of braunite, caryopilite, and chlorite. At the boundary between caryopilite-chlorite and braunite layers, a rind of near-end-member caryopilite (table 9 , analysis 7 ) separates the mixed silicate layer
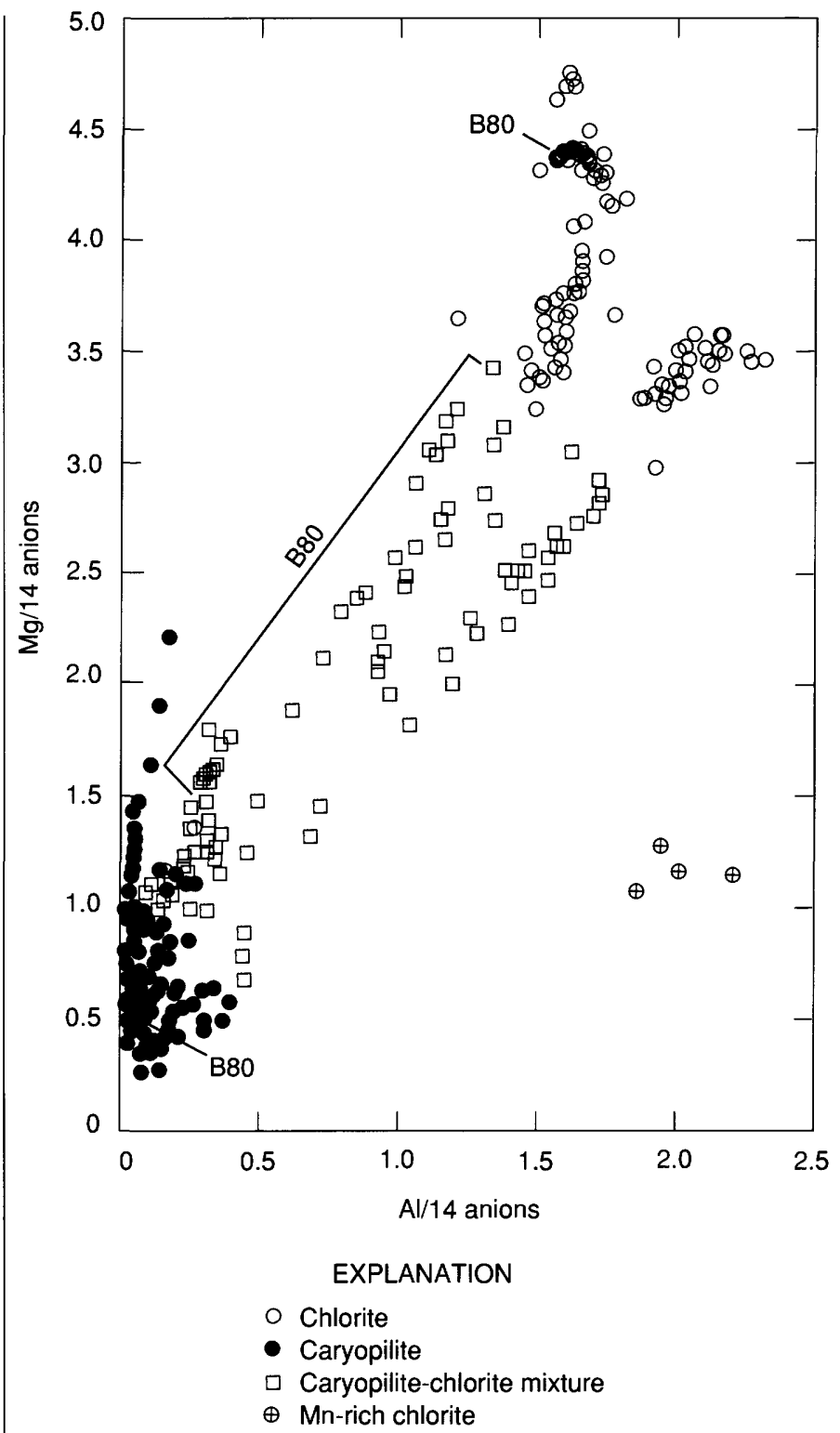

FIGURE 10.-Compositions of caryopilite and chlorites from sample B80 and 14 other samples from the Buckeye deposit, California. There appear to be two chlorite-composition clusters and two mixing lines toward caryopilite. Caryopilite analyses from sample B80 cluster at very Mg-poor compositions, chlorite analyses cluster at very Mg-rich compositions, and caryopilite-chlorite mixtures span a very large compositional range. The gaps between the endmember caryopilite and chlorite compositions and the compositions of the caryopilite-chlorite mixtures in sample B80 illustrate the lack of equilibrium between caryopilite and chlorite as discussed in the text.

from the oxide layer. The compositions of the caryopilite rind, mixed caryopilite-chlorite, and chlorite in B80 are indicated in figure 10. The mixed layer in B80 has compositions that span almost the entire range of the high-Mg trend of the mixed caryopilite-chlorite analyses from all samples; in B80, however, caryopilite and chlorite are distinctly more $\mathrm{Mg}$-poor and $\mathrm{Mg}$-rich, respec- 
tively, than the mixing line, illustrating the lack of equilibrium between the silicate phases. Further, the rind of caryopilite is not the result of equilibration between the mixed silicate and oxide layers, as no correlations between compositions of caryopilite and braunite were found. The amount of substitution of other cations for $\mathrm{Mn}$ in caryopilite from B80 is among the least found in the Buckeye samples, and these compositions (and those from B24, table 9, analysis 5) probably represent the purest caryopilite in the Buckeye samples.

Most chlorite is the product of incipient recrystallization of gel-like material. Rarely, chlorite forms claylike layers (B24). Most chlorites are poorly crystallized, and their compositions are generally magnesian and siliceous, with about 4-16 weight percent $\mathrm{MnO}$ and as much as 2 weight percent $\mathrm{FeO}$. Chlorite that forms claylike layers in B24 has a composition very similar to the pink isotropic gel-like material in B24 (table 8, analysis 4), containing only slightly less $\mathrm{Mg}$ and $\mathrm{Al}$ and slightly more $\mathrm{Mn}$ and $\mathrm{Si}$. There is no correlation between the degree of crystallization of the gels and their compositions (table 8, analyses 3-8). Coarsely crystalline chlorite is uncommon (found only in B38 and B84), and its composition overlaps that of the gel-like and claylike layers. Cation sums of the coarsely crystalline chlorite are low (fig. $8 \mathrm{~A}$, table 9 , analysis 8 ), suggesting that some disorder may exist within the structure or that very minor amounts of caryopilite may be interlayered with the chlorite. Compositions of the Mg-chlorites, including gels having chlorite composition, are variable within single samples, particularly with respect to the amount of manganese. This variation may in part be due to fine-scale mixing with caryopilite. The compositional boundary between chlorite and caryopilite-chlorite mixtures (figs. 9, 10) is arbitrarily defined at 23 weight percent $\mathrm{MgO}$, corresponding to about $3.2 \mathrm{Mg}$ cations per 14 anions. The concentrations of minor elements ( $\mathrm{Fe}, \mathrm{Ni}, \mathrm{Zn}, \mathrm{V}$, and $\mathrm{Ti}$ ) vary considerably between samples. With the exception of smectite, chlorite has the highest concentrations of $\mathrm{Zn}$ and $\mathrm{Ni}$. In chlorite and caryopilite-chlorite mixed layers, $\mathrm{Ni}$ and $\mathrm{Zn}$ concentrations are greatest in the Mg-rich mixed layers (fig. 11). In some samples, chlorite and chlorite-composition gel exhibit a range of textures, again with no correlation between textures and compositions. In B24, however, two distinct groups of gels with chloritelike composition were found. One, discussed above (table 8 , analysis 4) forms a layer-fragment of essentially isotropic pink gel-like material that contains rhombohedra of rhodochrosite. The second material with chloritelike composition (table 8 , analysis 5) is partially crystallized and colorless; it occurs within layers of rhodochrosite with either caryopilite or phase A (fig. $8 E$ ) and has significantly less $\mathrm{Al}$ and more $\mathrm{Si}, \mathrm{Fe}, \mathrm{Ni}$, and $\mathrm{Zn}$ than the pink gel-like material.
A trace quantity of material with the composition of the Mn-rich chlorite, pennantite, was found disseminated within caryopilite in only one sample (B31, table 9, analysis 9).

\section{TANEYAMALITE AND PHASE A}

Taneyamalite, the Mn analogue of howieite (table 1), and a compositionally similar phase (referred to in this report as phase A) occur as discrete crystals. More commonly, they occur as intimate mixtures that show a range of compositions. Because of the close association, the two phases are discussed together.

The best formed taneyamalite occurs interlaminated with caryopilite or chert. Taneyamalite laminations in chert appear to be thin protoliths. When interlaminated with caryopilite, taneyamalite also forms soft-sediment injection veins (fig. $5 B$ ). Examination of one such vein in B24 with the scanning electron microscope showed fine fibers and laths. Taneyamalite also forms isolated bundles or tufts of radiating fibers within chert laminations adjacent to the orebody. These fibers are morphologically similar to fibers of phase A. There is considerable variation in the composition of taneyamalite, both within a single sample and between samples (fig. 9). Taneyamalite in layers or veins contains less $\mathrm{MgO}, \mathrm{Al}_{2} \mathrm{O}_{3}$, and $\mathrm{SiO}_{2}$, and more $\mathrm{FeO}$ and $\mathrm{MnO}$, than taneyamalite in isolated tufts (table 9 , analyses 13-14). These differences may be caused by contamination with fine-grained smectite, which is ubiquitous in some chert layers. All taneyamalite analyzed in our samples is deficient in sodium relative to the ideal formula of Matsubara (1981), $\mathrm{NaMn}_{12} \mathrm{Si}_{12}(\mathrm{O}, \mathrm{OH})_{44}$. Under the microprobe beam, the $\mathrm{Na} \mathrm{X}$-ray count rate did not decrease with time, indicating that $\mathrm{Na}$ was not lost due to exposure to the electron beam. Thus, the sodium deficiency appears to be real and to reflect either deviations from the ideal structural formula or intergrowth with a Na-poor phase such as phase A (see below). Taneyamalite from other samples has compositions within the range of the analyses plotted in figure 12 (values given are cations per formula unit):
Sample
$\mathrm{Na}$
Fe

$65 \mathrm{H} 66 \ldots \ldots \ldots \ldots \ldots \ldots \ldots \ldots \ldots . .6 .722-0.860 \quad 1.229-1.458$

$65 \mathrm{H} 68 \ldots \ldots \ldots \ldots \ldots \ldots \ldots \ldots \ldots \ldots$
$0.824-0.859 \quad 1.266-1.318$

B10......................... $0.732-0.872 \quad 0.744-1.099$

B7 ....................... $0.683-0.862 \quad 0.852-1.101$

In most samples, the nickel and zinc contents of taneyamalite are at or below the detection limits of the microprobe, although in several samples (B24, B38, B71) as much as 0.74 weight percent $\mathrm{ZnO}$ was found.

Phase $A$ occurs as bundles of radiating yellow fibers in rhodochrosite (B24, fig. $8 E$, table 9 , analysis 10 ). Compared with taneyamalite, phase A contains notably more 


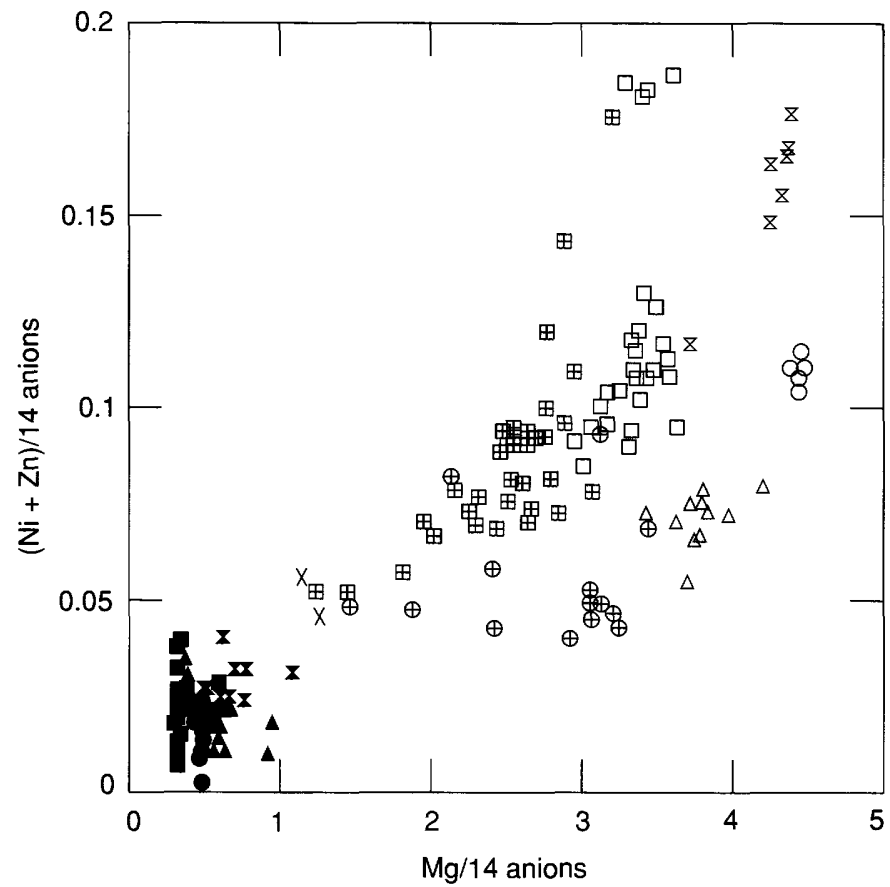

\section{EXPLANATION}

\begin{tabular}{|c|c|c|c|}
\hline & B24 & B80 & B95 \\
\hline Caryopilite & - & - & $\mathbf{x}$ \\
\hline $\begin{array}{l}\text { Caryopilite-chlorite } \\
\text { mixture }\end{array}$ & 田 & $\oplus$ & $x$ \\
\hline Chlorite & $\square$ & 0 & 8 \\
\hline
\end{tabular}

$A$

Figure 11.-Relationship between $\mathrm{Ni}, \mathrm{Zn}$, and $\mathrm{Mg}$ in caryopilite, chlorite, and mixtures of the two minerals from the Buckeye mine, California. $A$ shows that $\mathrm{Ni}$ and $\mathrm{Zn}$ are associated with $\mathrm{Mg}$-rich (chlorite-rich) compositions, but $B$ shows that the proportion of Ni to $\mathrm{Zn}$ is variable in the Buckeye deposit.

Fe and much less Na. The formula of phase A (table 9, analyses 10-11), calculated on the same anion basis as taneyamalite, yields similar cation values and sums. This similarity suggests that phase A may be Na-depleted taneyamalite, analogous to $\mathrm{K}$-depleted zussmanite, $\mathrm{K}_{0-1} \mathrm{AlM}_{13} \mathrm{Si}_{12} \mathrm{O}_{42}(\mathrm{OH})_{14}$, which rims K-rich zussmanite in ferruginous metachert (Muir Wood, 1980). Although the K-depleted zussmanite described by Muir Wood appears to be the result of leaching, phase A occurs intergrown with taneyamalite, occurs as well-formed crystals, and does not appear to be a product of alteration. On the possibility that phase $\mathrm{A}$ is the $\mathrm{Mn}$-rich analogue of deerite, $\left(\mathrm{Fe}^{+2}, \mathrm{Mn}\right)_{6}\left(\mathrm{Fe}^{+3}, \mathrm{Al}_{3} \mathrm{Si}_{6} \mathrm{O}_{20}(\mathrm{OH})_{5}\right.$, as taneyamalite is of howieite, we calculated analyses of phase A to the deerite formula (15 cations:22.5 oxygens). Analyses of phase $\mathrm{A}$ approach the formula $\mathrm{M}_{7}^{+2} \mathrm{M}^{+3} \mathrm{Si}_{7} \mathrm{O}_{20}(\mathrm{OH})_{5}$, although most analyses have excess $\mathrm{Si}$ and a deficiency of divalent and trivalent cations relative to this formula. Recalculation of phase A analyses to other formula units proved unsuccessful. We

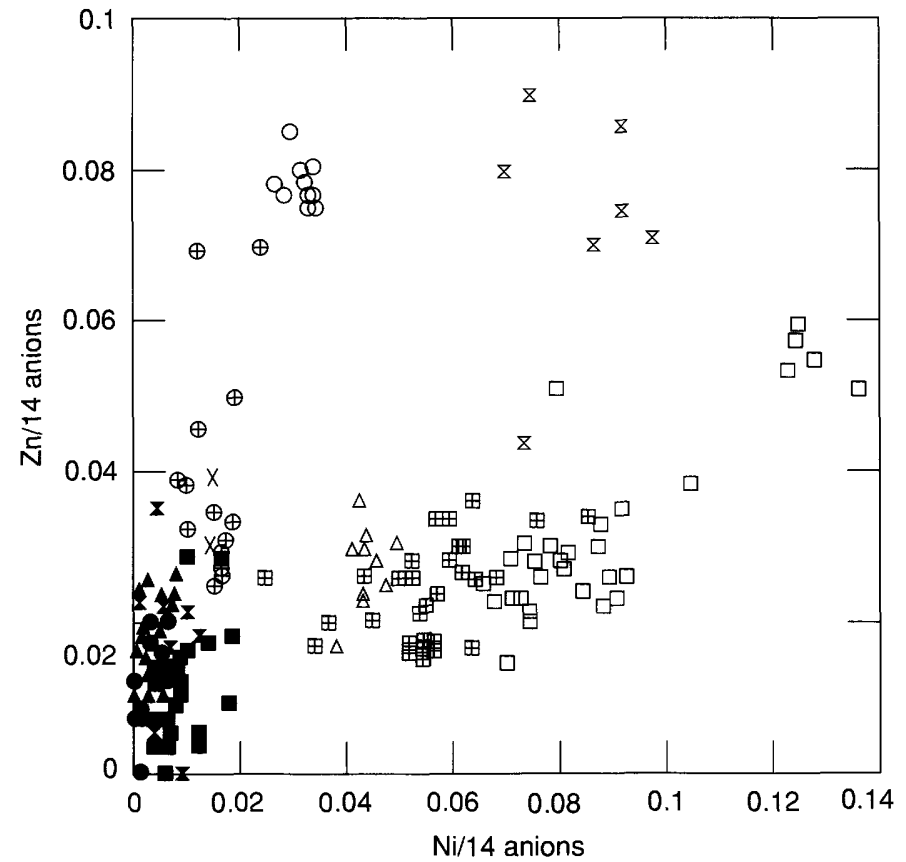

EXPLANATION

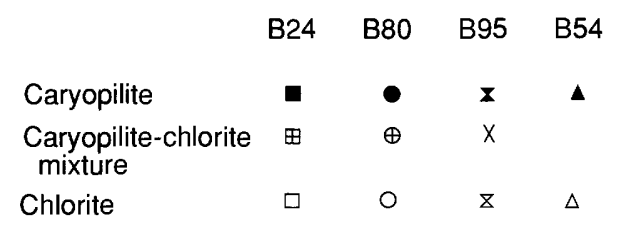

calculated phase A by using the taneyamalite formula unit and effective ionic radii for tetrahedrally and octahedrally coordinated cations (Shannon, 1976) and found it to be unlike any of the modulated 2:1 structures considered by Guggenheim and Eggleton (1987, their fig. 5a). On the basis of their scheme, phase $\mathrm{A}$ recalculated according to the formula unit $\mathrm{M}_{7}^{+2} \mathrm{M}^{+3} \mathrm{Si}_{7} \mathrm{O}_{20}(\mathrm{OH})_{5}$ has a mean octahedrally coordinated cation radius (all cations except $\mathrm{Na}, \mathrm{Ca}$, and $\mathrm{Si}$ ) that ranges from $0.78 \AA$ to $0.79 \AA$ and a mean tetrahedrally coordinated cation radius ( $\mathrm{Si}$ ) of $0.26 \AA$. These values plot near the boundary of the known field for zussmanite, suggesting that phase A is structurally similar to zussmanite. Phase A most commonly occurs in layers intergrown with taneyamalite, and its presence is deduced from microprobe analyses (table 9 , analysis 12) showing compositions that lie between those of taneyamalite and those of the fibers in B24. Layers of mixed phase $\mathrm{A}$ and taneyamalite also occur in B38 (fig. $8 A$ ). In that sample, the analyses that are richest in phase A component have significant vanadium (table 9 , 


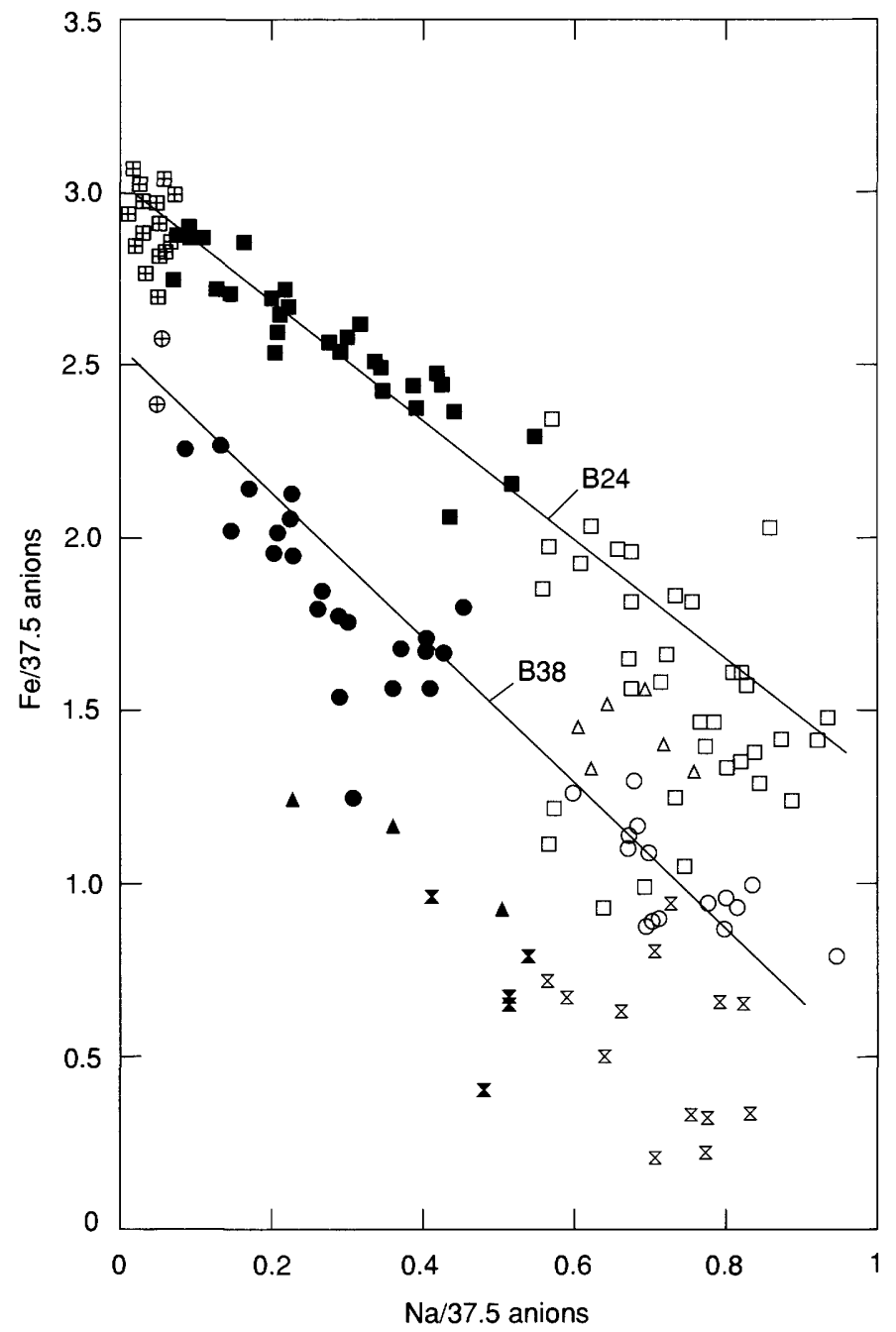

EXPLANATION

$\begin{array}{lcccc} & \text { B24 } & \text { B38 } & \text { B20 } & \text { B71b } \\ \text { Taneyamalite } & \square & 0 & \text { × } & \Delta \\ \begin{array}{l}\text { Taneyamalite- } \\ \text { phase A mixture }\end{array} & \square & \bullet & \text { х } & \Delta \\ \text { Phase A } & \boxplus & \oplus & & \end{array}$

FIGURE 12.-Distribution of taneyamalite and phase A compositions in four samples from the Buckeye deposit, California. Compositions from B24 and B38 appear to define two distinct mixing lines, although there is overlap at the more sodic compositions.

analysis 11), and analyses that are richest in taneyamalite have minor amounts of titanium, indicating that $\mathrm{V}$ and $\mathrm{Ti}$ are associated with phase $\mathrm{A}$ and taneyamalite, respectively.

Mixed layers of phase A and taneyamalite are far less common than mixed layers of caryopilite and chlorite. Compositions with at least 1 weight percent $\mathrm{Na}_{2} \mathrm{O}$, equivalent to 0.5 cations per formula unit, are here defined as taneyamalite; those with 0.1 to 1 weight percent $\mathrm{Na}_{2} \mathrm{O}$ as phase $\mathrm{A}$-taneyamalite mixtures; and those with less than 0.1 weight percent as phase A. In mixtures of taneyamalite and phase A, sodium and iron define a linear trend when plotted against each other (fig. 12). Each sample defines its own trend, although the distinction is lost as phase A composition is approached. Analyses from sample B71b form two distinct groups, with taneyamalite analyses displaced to higher $\mathrm{Fe}$ values than those of mixed taneyamalite and phase A, suggesting that an additional phase may be present in the mixture-perhaps smectite, which would account for the high $\mathrm{Mg}$ contents of the mixtures.

\section{SANTACLARAITE}

Santaclaraite is invariably associated with rhodochrosite, quartz, and smectite. These minerals form irregular veins or "intrusions" (B7; B20; B25, fig. $4 C$; B84, fig. $4 E$; B91) that cut across laminations of protolith and may have been pathways for escaping fluids. Fragments of caryopilite layers are suspended in the "intrusion" in figure $4 C$. The details of the paragenesis are not clear. It is certain, however, that these veins postdate early consolidation of the caryopilite and chlorite protoliths and that much of the santaclaraite has subsequently been replaced.

Santaclaraite is recognized by its rhodonite-like morphology, brilliant second-order birefringence, and characteristic X-ray reflections at $11.5^{\circ}, 12.6^{\circ}, 18.5^{\circ}$, and $28.3^{\circ}$. We confirm the discrepancy between the strong calculated and weak observed intensities of the (0-24) reflection at $33.2^{\circ}$ (Erd and Ohashi, 1984). The laths are so characteristic that pseudomorphs of santaclaraite by rhodochrosite can be easily recognized. These are the pseudomorphs noted by Huebner (1967). We found no evidence for the occurrence of either rhodonite or pyroxmangite at the Buckeye deposit. In B7, B20, and $65 \mathrm{H} 68 \mathrm{~B}$, santaclaraite has a very narrow compositional range, represented by santaclaraite in B7 (table 9 , analysis 15). Analyses yield cation proportions that are in excellent agreement with the ideal structural formula, $\mathrm{CaMn}_{4}\left[\mathrm{Si}_{5} \mathrm{O}_{14}(\mathrm{OH})\right](\mathrm{OH}) \cdot \mathrm{H}_{2} \mathrm{O}$ (Ohashi and Finger, 1981). Santaclaraite from the Buckeye deposit is more homogeneous but has slightly more substitution of $\mathrm{Fe}$ and $\mathrm{Mg}$ for Mn than the type material (Erd and Ohashi, 1984), which is from another Mn deposit in the Franciscan Complex.

\section{RHODOCHROSITE}

The carbonate adopts four distinct textural forms: micritic, spherulitic, tufted, and sparry. Sparry rhodochrosite forms by the direct recrystallization of the micrite, without passing through intermediate stages. The spherulites are uncommon, fibrous, exhibit a distinct 
black cross under crossed nicols, occur in micrite, and appear to be a secondary, probably diagenetic, feature. The rare tufts are composed of well-aligned fibers; by analogy with the sperulites we presume that the tufts are also diagenetic. There is no systematic compositional distinction between these forms. Rhodochrosite from six bulk samples (B22, B28, B35, B45, B74, B108) has cell dimensions of $a=4.775-4.782 \AA$ and $c=15.63-15.69 \AA$, close to the values for pure $\mathrm{MnCO}_{3}, 4.777 \AA$ and $15.66 \AA$ (Huebner, 1967). Primary micritic and recrystallized sparry rhodochrosites commonly contain less than 2.4 weight percent each of $\mathrm{CaO}$ and $\mathrm{MgO}$ (table 11, analyses 1-4). Values of 3 to 8 weight percent $\mathrm{CaO}$ are uncommon (fig. $8 E$, table 11 , analysis 5). Within a given sample, both micritic and sparry rhodochrosite have about the same compositional range, consistent with the idea that the sparry carbonate is simply recrystallized micritic protolith. Except for very small concentrations of iron, no other elements were detected in the carbonate by means of wavelength- or energy-dispersive microprobe techniques. Specifically, we did not detect $\mathrm{Ni}, \mathrm{Ba}$, or $\mathrm{Sr}$ in the carbonate grains. Some rhombohedra are zoned, having slightly higher calcium in cores than in rims. A slightly higher concentration of magnesium was found in rims of rhodochrosite grains in one sample (B53, table 11, analyses 2-3); these grains are in contact with braunite, but no corresponding zonation in $\mathrm{MgO}$ was found in the braunite. Rhodochrosite that forms crosscutting veins can contain as much as about 10 weight percent $\mathrm{CaO}$ and 3 weight percent $\mathrm{MgO}$ (analysis 6 in table 11 is representative). Compositions are variable within a single vein and between samples (see table 11 and fig. 9).

\section{BRAUNITE}

Braunite has close to the ideal composition of braunite I, $\left(\mathrm{Mn}^{+2}\right)_{6}\left(\mathrm{SiMn}^{+3}\right) \mathrm{O}_{24}$ (Baudracco-Gritti, 1985). The composition (fig. 9) varies little within a single sample, but differences between samples were noted, particularly in the iron content. The range of $\mathrm{Fe}_{2} \mathrm{O}_{3}$ is 0.20 to 1.64 weight percent (all $\mathrm{Fe}$ is assumed to be ferric). Minor amounts of $\mathrm{Ca}, \mathrm{Mg}$, or $\mathrm{Ni}$ occur in some samples. The compositions of braunite both in contact with and more distant from rhodochrosite in B53 are given in table 12 (analyses 1 and 2). The calcium and magnesium values are not significantly different, but the braunite in contact with carbonate contains slightly more nickel and iron and less manganese. Braunite in B53, which forms distinct layers, appears to be texturally variable. In parts of the sample, braunite appears to be fine grained and intergrown with equally fine-grained rhodochrosite, but, where in contact with coarse rhodochrosite, braunite forms coarse grains. In other layers, cores of braunite grains contain blebby to irregularly shaped rhodochros- ite grains. Rims of these braunite grains, whether in contact with other braunite grains or with the adjacent rhodochrosite layer, show the same coarsening as observed in the fine-grained braunite and rhodochrosite layers, with the same variation in composition (cores contain less nickel and iron). In sample B80 (fig. $8 B$ ) a compositional difference between coarse and fine braunite is also found. Coarse braunite contains significantly less iron and calcium and more manganese than the finer grains. Despite the range of textures and minor-element compositions, the Si concentration in Buckeye braunite is constant, at a value of 1 atom per 12-oxygen formula unit. Braunite can occur with hausmannite (B6, fig. $8 F$; $65 \mathrm{H} 170$ ), but no partitioning of iron on the basis of weight percent concentration was found between these two oxides (table 12 , analyses 3,5 and 4,8 ).

\section{HAUSMANNITE}

Hausmannite has close to endmember composition. Manganese greatly exceeds all other cations, and, when recalculated on the basis of an ideal $\mathrm{Mn}^{+2} \mathrm{Mn}_{2}^{+3} \mathrm{O}_{4}$ formula unit, the analyses total approximately 100 percent (fig. $9 B$; table 12 , analyses 5-8). Significant but very small concentrations of $\mathrm{Fe}, \mathrm{Mg}, \mathrm{V}, \mathrm{Zn}, \mathrm{Ni}, \mathrm{Ca}, \mathrm{Ti}$, and $\mathrm{Si}$ were detected. Most of the slight composition variation was found between samples, with very small ranges of compositions within a single thin section.

\section{DISCUSSION}

The fine-grained textures and microprobe analyses expand the idea that the ore originated as chemically precipitated sediments in which eight components formed layers (protoliths). The new observations are a ninth component (phase A) and mixed layers. Thus, the deposit consists of layers of one component and mixtures of two components. This distribution is what would be expected if the conditions of a sedimentary environment changed such that one field of deposition or chemical precipitation was supplanted by another. The mixtures would form if conditions coincided with those of two or three depositional fields or, more likely, if there was mechanical mixing as chemical precipitates settled into place. Although the textural and microchemical evidence indicates a lack of equilibrium during diagenesis and metamorphism, the fine laminae of contrasting compositions do indicate that processes in the depositional environment also changed, presumably in response to changing conditions, involving the rates of supply of the major components $\mathrm{MnO}, \mathrm{CO}_{2}, \mathrm{O}_{2}, \mathrm{H}_{2} \mathrm{O}, \mathrm{SiO}_{2}$, and $\mathrm{Al}_{2} \mathrm{O}_{3}$ and the minor components $\mathrm{Na}_{2} \mathrm{O}, \mathrm{MgO}$, and $\mathrm{FeO}$. 


\section{VEIN MINERALS}

Two generations of veins occur. Earlier veins tend to be narrow (less than $100 \mu \mathrm{m}$ ), short (less than $2 \mathrm{~mm}$; rarely to $3 \mathrm{~cm}$ ), and devoid of fragments of transected layers. They are monomineralic and reflect the mineralogy of adjacent protolith. There is no chemical distinction between these vein minerals and the corresponding minerals in the adjacent metasediments. Later veins are wide (to $2 \mathrm{~cm}$ ), traverse many layers, and commonly contain fragments of the transected protoliths. The late veins are polymineralic; in addition to wall-rock fragments, they contain either quartz or rhodochrosite and minerals that are chemically distinct from the minerals in the enclosing protoliths. These veins introduced additional chemical components to the ore-forming system, and there is a correspondence between these components and the characteristic vein mineralogy. The presence in the veins of titanite, a stilpnomelanelike mineral such as parsettensite, barite, smectite, clinopyroxene, and various unidentified minerals is evidence that $\mathrm{Ti}, \mathrm{K}, \mathrm{Ba}, \mathrm{SO}_{4}$, $\mathrm{Mg}, \mathrm{Na}, \mathrm{V}$, and As were mobile after the host sediments became indurated. These minerals are not as $\mathrm{Mn}$-rich as the protoliths, and many plot primarily along the join between Si and "others" (fig. $9 B$ ).

Talc forms veins that cut across spherulitic rhodochrosite (B71) and are composed of pale yellow "books" about $40 \mu \mathrm{m}$ across; it has near endmember composition with only minor substitution of $\mathrm{Mn}$ and $\mathrm{Fe}$ for $\mathrm{Mg}$ (table 10 , analysis 1). The relative time of formation is not known but is probably late.

Smectite and related interlayer compounds occur as fine to coarse $(100-\mu \mathrm{m})$ colorless flakes in quartz and rhodochrosite veins and as minute pale brown flakes in $\mathrm{Mn}$-silicate layers and in laminated chert. These smectites were identified by their optical properties, composition, and expandable basal X-ray diffraction reflections at $14 \AA$ to $25 \AA$. Chemically analyzed (coarse) smectites from Buckeye samples have the composition of the trioctahedral smectite, saponite. Some smectite is similar to talc in that minor amounts of iron and manganese substitute for magnesium (table 10, analysis 2). Other smectites contain as much as 1.66 weight percent $\mathrm{NiO}$ and 1.59 weight percent $\mathrm{ZnO}$ (table 10 , analysis 3 ). In minor-element concentrations, these latter smectites are similar to the gel-like material of Mg-chlorite composition.

Several laths with the composition of parsettensite, a manganese-rich stilpnomelane-like mineral, were found in a quartz-barite-apatite vein in one sample, B29. This phase has near endmember parsettensite composition, and only minor substitution of $\mathrm{Mg}$ for $\mathrm{Mn}$ (table 10 , analysis 4). It is the only silicate analyzed in this study that contains significant barium.
Barite occurs in the aforementioned quartz-apatiteparsettensite vein and as a replacement (or in-filling) of a unique patch of colloform rhodochrosite in B29.

Apatite occurs only as a minor constituent in quartz veins.

Diopsidic acmite with slight pleochroism in green to yellow green occurs with titanite and apatite in quartz veins that cut across the sample of the diopsidic acmite bed collected from the exploration adit (B94 and B96). The vein-forming clinopyroxene is similar in composition to the acmitic host and was undoubtedly derived from the adjacent layer. The concentration of jadeite component is small, 3 mole percent (table 10, analysis 5).

The vanadium-rich silicate referred to herein as phase B (B15, table 10, analysis 6) forms pleochroic light- to medium-green fibers and laths within quartz veins that cut rhodochrosite. The crystals are very small, the maximum dimensions being about 5 by $150 \mu \mathrm{m}$, and were too small to obtain an interference figure. The crystals have approximately parallel extinction, maximum interference colors of low second order, and relief greater than that of quartz. The reflectivity of phase B is slightly greater than that of pyroxene. The composition of phase $B$ does not correspond to that of any vanadium silicate reported by Evans and White (1987). X-ray or electron diffraction data are needed.

Another vanadium-rich silicate, presumably a single phase (table 10, analyses 7-9), is herein called phase C and occurs in quartz veins in B15, the same sample as phase $\mathrm{B}$. Phase $\mathrm{C}$ is pleochroic pink to colorless and forms columnar laths; rarely, hexagonal forms are observed. This mineral has pronounced optical and compositional zoning, with cores being enriched in aluminum and depleted in vanadium compared to rims. A very good negative correlation between aluminum and vanadium exists in all grains analyzed. This mineral is uniaxial (-) and has parallel extinction, relief greater than that of quartz, and a reflectivity slightly greater than that of pyroxene. Its crystal habit, optical properties, and pronounced zoning are like those of tourmaline-group minerals, but cation proportions are not consistent with the formulae for tourmalines. It is conceivable that phases $B$ and $\mathrm{C}$ form a solid-solution series, $\mathrm{Na}_{0.0-0.5} \mathrm{Ca}_{2-3}(\mathrm{Al}, \mathrm{V})_{5}$ $\mathrm{Si}_{6} \mathrm{O}_{24}$. X-ray diffraction data are needed.

An arsenian vanadium- and manganese-bearing phase, presumably a hydrous vanadate, was found in sample B17 (table 10, analysis 10). Phase D is orange red, has a fine-grained texture, and appears as pseudomorphs of a phase within rhodochrosite. Its deep color masks its interference colors. Phase D has a reflectivity greater than that of titanite but lower than that of an oxide. This mineral has also been found in hausmannite- and 
tephroite-rich samples from the Manga-Chrome mine located in Nevada County, Calif. (Flohr and Huebner, unpub. data), and is probably related to flinkite, $\mathrm{Mn}_{3}$ $\left(\mathrm{AsO}_{4}\right)(\mathrm{OH})_{4}$.

Well-crystallized titanite occurs in several samples and is associated with quartz veins, particularly in the massive diopsidic acmite, and as trains of crystals in caryopilite. Titanite contains less than 1 weight percent $\mathrm{V}_{2} \mathrm{O}_{3}$ and no significant amounts of other minor elements. Its occurrence, particularly in the veins, is evidence that $\mathrm{Ti}$ was mobile at the low temperature involved in modifying the manganese deposit.

Trace quantities of minute yellow and gray sulfide grains (probably pyrite, chalcopyrite, chalcocite, covellite or digenite, molybdenite, and possibly sphalerite) occur in veins. The grain size was not sufficient for quantitative microprobe analysis, but X-ray spectra revealed peaks for $\mathrm{Cu}, \mathrm{Mo}$, and $\mathrm{S}$. The paragenesis of the sulfide-bearing veins is not certain; they are thin and short, like the early veins, yet they introduce additional components, like the later veins. The fact that Buckeye minerals contain $\mathrm{Mn}^{+3}$ coupled with the absence of appreciable quantities of iron sulfide in or near the Buckeye deposit suggests that the adjacent sediment column was never so reducing that marine sulfate was reduced to make sulfide available for sulfide precipitation. (Thus the presence of even minute quantities of copper sulfides signals a local origin or later activity.)

The veins provide clues to the mobile components after the manganiferous sediments were sufficiently well indurated to fracture. During the first stage of vein formation, the manganiferous components of the protoliths were mobile but did not travel far. During later vein formation, the protoliths were more thoroughly indurated (resulting in brecciation), and, with few exceptions, the manganiferous components were not mobile. The source of the later vein fluids is not known with certainty, but in composition the vein minerals tend to have affinities with seawater and nonmanganiferous marine sediments. Perhaps these late mobile components were incompatible components that were carried by fluids expelled during compaction of the sediment pile. The precipitation of well-crystallized titanite in a low-temperature sedimentary deposit was not expected and is evidence that $\mathrm{Ti}$ can be mobile and concentrated even in an environment in which the bulk composition is unusually low in titanium. Similarly, Brett and others (1987) found anatase in hydrothermal vent chimneys. As a general rule at the Buckeye, occurrence of an element (or pair of elements) corresponds to the appearance of a vein mineral, indicating that the chemical system was responding in a predictable manner to changes in the fluid compositions. Thus, Ba results in the parsettensite- like mineral, $\mathrm{Ba}$ and $\mathrm{SO}_{4}$ in barite, $\mathrm{PO}_{4}$ in apatite, and $\mathrm{Ti}$ in titanite.

\section{ORIGIN}

Two theories for the origin of the Buckeye and similar deposits are currently popular and involve hydrothermal and diagenetic processes. In the following pages we discuss some marine sedimentary processes known to be depositing or redistributing manganese today and examine some modern and ancient deposits in terms of these processes. None is an excellent analogue for the Buckeye deposit, which can best be explained on the basis of two interacting processes such that diagenesis influences the composition of fluids that vent at the seafloor. Finally, we discuss possible tectonic settings for the Buckeye deposit.

\section{MODERN PROCESSES OF MARINE MANGANESE DEPOSITION}

Modern marine environments contain no interlayered manganese carbonate-oxide-silicate deposits that are analogues of the Buckeye deposit, but examination of the processes that deposit and redistribute manganese at ocean-floor environments will help us understand the origin of deposits such as the Buckeye. In principle, there appear to be three kinds of processes: hydrogenous, diagenetic, and hydrothermal. In practice, many manganese deposits record more than one of these processes. Hydrothermal deposition is usually thought to involve hot fluids, but recent monitoring of some seafloor vents that are associated with Mn-rich precipitates in areas of igneous activity reveals water that is barely above ambient seafloor temperature (Hoffert and others, 1978; Vonderhaar and others, 1987). These cool vents cast doubt on the necessity of heat for Mn transport, Mn precipitation, and even fluid movement, thereby suggesting the possibility that some Mn precipitates could be related to fluid expulsion driven by compaction and subduction instead of by thermal convection. The three processes of Mn precipitation are better distinguished if, for the purposes of this discussion, we define a hydrothermal processs as one that involves transport with a moving fluid either beneath or above the seafloor, a hydrogenous process as one that involves precipitation and gravity settling of particulates through a stationary fluid above the seafloor, and a diagenetic process as one that involves the diffusion of dissolved species through a stationary fluid, commonly below the seafloor. Each of the three processes can result in a distinct product. Characteristic features of these products, when compared with the Buckeye ore, may provide clues to the origin of the Buckeye deposit. These characteristics, which are discussed below and in summaries by Margolis 
and Burns (1976), Cronan (1977), Raab and Meylan (1977), Rona (1978), Toth (1980), Fleet (1983), and Lalou (1983), are compared with features of the deposit in table 13. Because we are discussing marine environments, we, like Courtois and Clauer (1980), normalized the REE concentrations of the products to the REE concentrations of seawater (Hogdahl and others, 1968). In this way, we hope that our REE patterns will help us distinguish the signatures brought about by the operation of each of these processes upon fluid that, originally, was seawater.

Purely hydrogenous deposits form by the precipitation and settling of manganese and iron oxyhydroxides directly from cold seawater onto the top of the sediment column. This process results in nodules and crusts that are exposed at the sediment surface, thin coatings on fresh basalt, particles of Fe-Mn-oxyhydroxides in the sediment, and films of oxyhydroxides that coat detrital particles. Because the manganese concentration in normal seawater is only 0.03 parts per billion (ppb) (Bruland, 1983), the growth rates are slow and large nodules and thick crusts occur only on old ocean floor. A related factor is the occurrence of hydrogenous deposits in tectonically and volcanically inactive areas having low sedimentation rates. Thus, nodules and crusts commonly are found on siliceous ooze and red clay of deep ocean basins, below the carbonate compensation depth and far from sources of detritus, or where currents suppress sedimentation. The fields of nodules and crusts are regional in extent, and surface coverage may exceed 75 percent (Glasby, 1976). Nodules and crusts are layered, and their upper surfaces, which are directly exposed to seawater, commonly are smoother than the lower surfaces, which are exposed to sediment (see Heye and others, 1979; Marchig and Halbach, 1982). The nodules and crusts are highly oxidized (most manganese is quadrivalent and iron is trivalent). A characteristic $\mathrm{Mn}$ phase is vernadite (the $\delta-\mathrm{MnO}_{2}$ of Burns and Burns, 1977). Rhodochrosite and Mn-rich silicates, which require manganese that is predominantly divalent, never occur in association with the oxidized nodules and crusts at the sediment surface. Most hydrogenous nodules and crusts have ferromanganese compositions with $\mathrm{Mn} / \mathrm{Fe}$ ranging from 0.1 to 10 . Relative to diagenetic and hydrothermal components, the hydrogenous component is enriched in $\mathrm{Co}, \mathrm{Fe}$, Th, Hf, and the REE (Dymond and others, 1984). Halbach (1986) noted that hydrogenous crusts contain, on average, 0.5 parts per million (ppm) $\mathrm{Pt}$. The seawater-normalized REE signature of hydrogenous products (fig. 13A) is enriched overall, has a pronounced positive $\mathrm{Ce}$ anomaly (large $\mathrm{Ce} / \mathrm{La}$ and $\mathrm{Ce} / \mathrm{Sm}$ ), and is relatively depleted in the heavy REE. These enrichments can be attributed to long exposure to seawater, to the high surface areas of the precipitates, and to the tunnel structures of the constituent oxides.

Because of their tendency to undergo diagenetic alteration and to form on oceanic sediments that will ultimately be subducted, hydrogenous crusts and nodules are uncommon in the geologic record (Jenkins, 1977). We should look for thin (perhaps less than a meter thick) but laterally extensive horizons of nodules or crusts that contain, at least at low metamorphic grade, quadrivalent manganese oxides having nodular or knobby structure, perhaps preserving concentric layering, and having the characteristic chemical signature. One might look for this record in slowly deposited seafloor sediments that lie immediately below an unconformity or that have been preserved as fragments of ocean crust that were accreted to continents. Audley-Charles (1965) and Margolis and others (1978) described nodules and slabs (crusts) in Cretaceous red clay that forms an exotic block in an olistostrome on Timor. On the basis of their intermediate $\mathrm{Mn} / \mathrm{Fe}$, enrichment in $\mathrm{Co}, \mathrm{U}$, and Th, and high $\mathrm{Th} / \mathrm{U}$, some of these nodules may record a hydrogenous component. The crust and another nodule have high $\mathrm{Mn} / \mathrm{Fe}$ and low Co and may represent hydrogenous precipitates that have been altered by diagenetic processes. In contrast, the Buckeye deposit records none of the characteristics of the hydrogenous processes (table 13).

Early diagenetic processes involve pore fluids that act upon substances incorporated within marine sediments. These processes may redistribute earlier formed manganese-rich precipitates, progressively refining their chemistry through repeated dissolution, transport, and reprecipitation. Diagenesis that is driven by chemical disequilibrium between oxygenated seawater and unconsolidated sediments rich in organic material results in three chemically distinct products: ferromanganese oxyhydroxides formed by oxic diagenesis, manganeserich oxyhydroxides formed by suboxic diagenesis, and sulfides and manganese carbonate formed by anoxic diagenesis.

Processes that occur within the zone of dissolved oxygen (oxic zone) at the top of the sedimentary column (see Froelich and others, 1979) largely involve the redistribution of components that had a hydrogenous or detrital origin. Included are the release of trace metals from decomposing organic tissues and the extraction of iron and manganese from sedimentary components (opaline skeletal debris, hydrogenous coatings on sedimentary clasts) to form ferromanganese nodules and nontronite (Dymond and others, 1984; Lyle and others, 1984). The Mn oxidation state in the top $5 \mathrm{~cm}$ of sediment at two Pacific sites, 3.3 to 3.9 , greatly exceeds that in the suboxic zone where $\mathrm{Mn}$ is divalent (Kalhorn and Emerson, 1984). Under the oxidizing conditions near the surface, manganese and iron should remain in the 


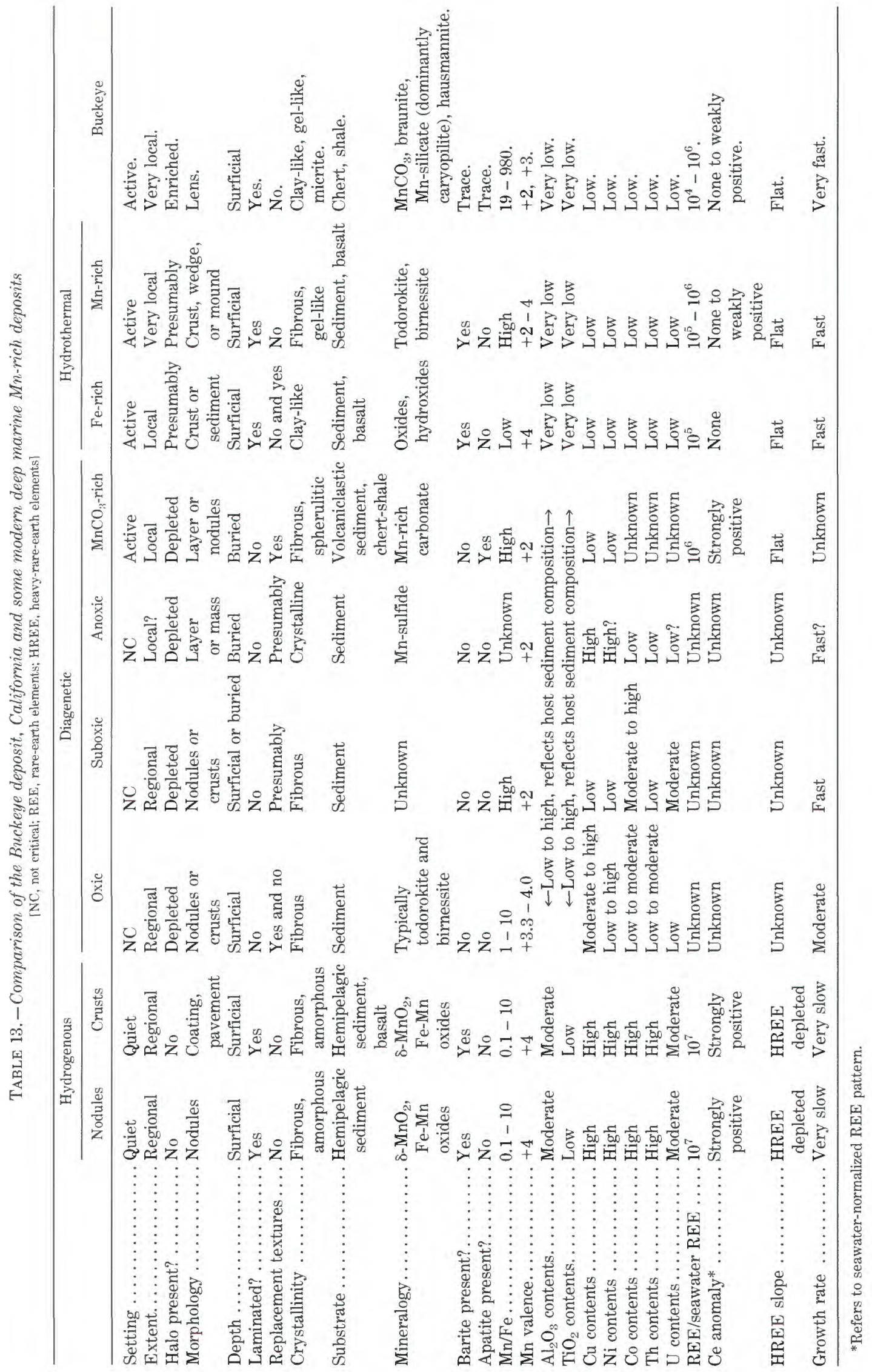



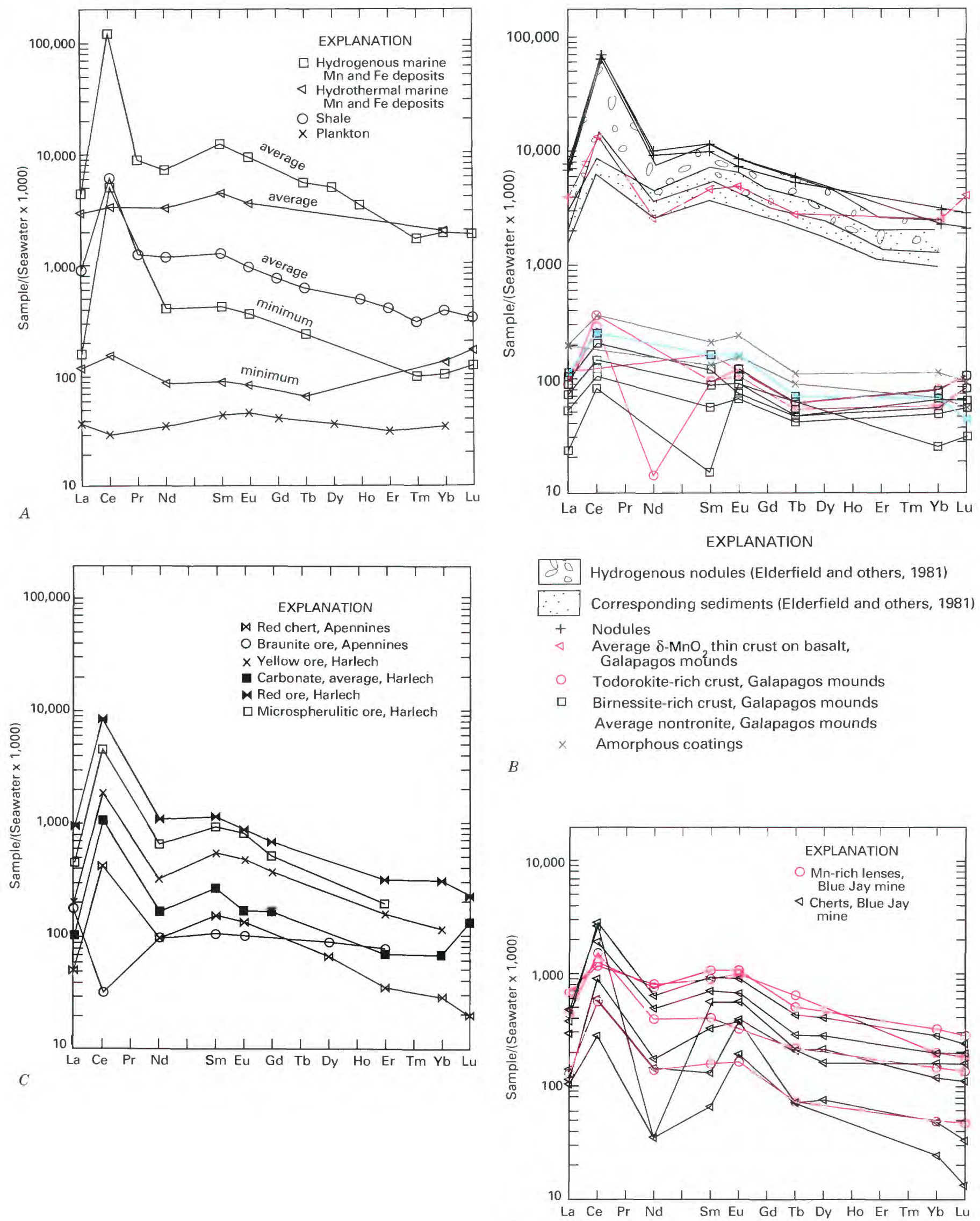


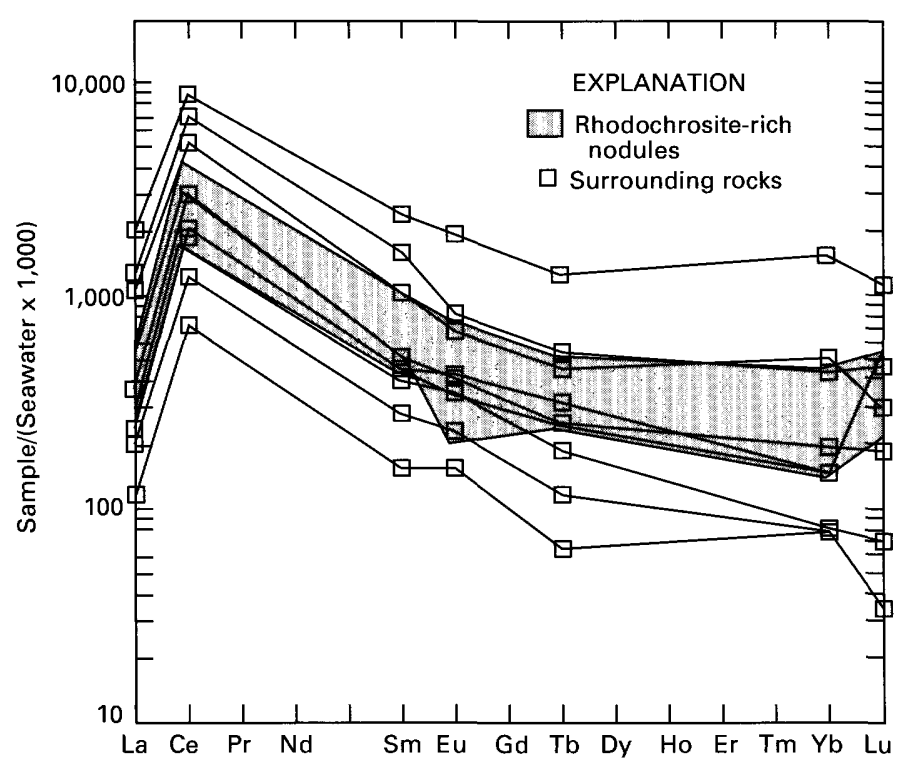

$E$

FIgURE 13. - Seawater-normalized rare-earth-element (REE) patterns of $\mathrm{Mn}$ - and Fe-rich deposits, exclusive of the Buckeye deposit and other materials. $A$, Recalculated from Fleet (1983) and Gromet and others (1984, average shale). Hydrogenous marine $\mathrm{Mn}-\mathrm{Fe}$ deposits have the greatest REE enrichment and Ce anomaly and are depleted in heavy relative to light REE. Hydrothermal marine $\mathrm{Mn}$ and $\mathrm{Fe}$ deposits are not as enriched overall, lack the Ce anomaly, and are flat (heavy REE neither enriched nor depleted). Shales are less enriched, overall, but have both the Ce anomaly and heavy REE depletion. Plankton show the least enrichment, relative to seawater, and lack fractionation between individual REE. $B$, Relationship between REE pattern and kind of precipitate. Hydrogenous nodules and the sediments on which they sit (Elderfield and others, 1981) have the greatest enrichment, the most pronounced Ce anomaly, and the greatest depletion of heavy relative to light REE. Thin $\delta-\mathrm{MnO}_{2}$ crusts on basalt dredged near the Galapagos mounds (Corliss and others, 1978) combine the overall enrichment and Ce anomaly that are characteristic of hydrogenous deposits but lack the depletion in heavy REE. Various crusts and sediments dredged from the Galapagos mounds (Corliss and others, 1978), and interpreted as having a hydrothermal origin, show a weak Ce anomaly but have acquired neither the overall REE enrichment nor the depletion in heavy REE that is characteristic of the hydrogenous deposits. REE patterns for the Buckeye ores (fig. $7 B$ ) are distinct from those of the hydrogenous materials but overlap with patterns of materials dredged from the Galapagos mounds. $C$, REE patterns for braunite-rich ore Z-17 and red chert Z-1R from the Apennines (Bonatti and others, 1976) and

quadrivalent or trivalent state and be insoluble in the pore fluids. However, some manganese remobilization occurs and may contribute substantially to nodule growth. Dymond and others (1984) concluded that oxic diagenesis was the principal process forming nodules at the three Pacific sites studied and resulted in $\mathrm{Ni}$ - and $\mathrm{Cu}$-rich manganese oxide (todorokite) with $\mathrm{Mn} / \mathrm{Fe}$ of 5 to 10. Under steady-state conditions in which oxygen was being consumed by the sediment, Sundby and others (1986) and Westerlund and others (1986) found that surficial sediment immobilized $\mathrm{Fe}, \mathrm{Mn}$, and Co from both

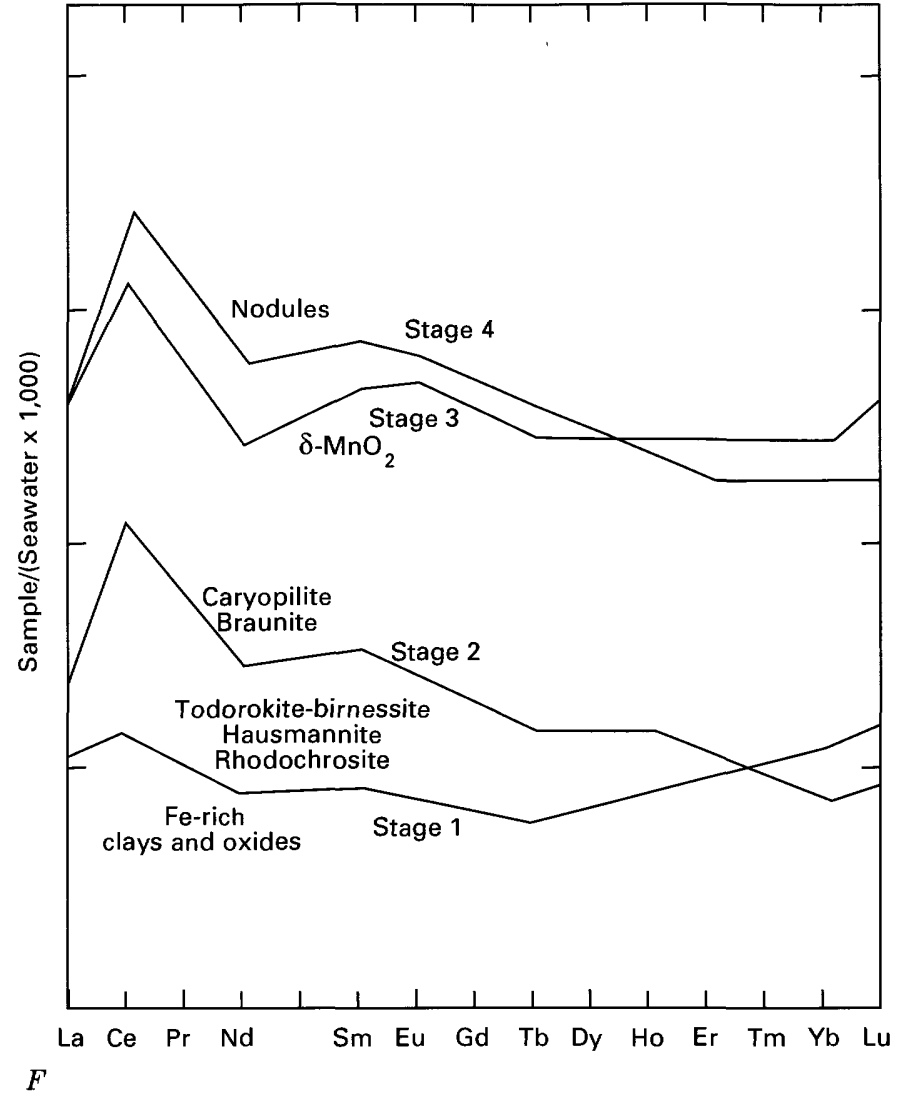

for the red, microspherulitic, yellow, and carbonate ores from Harlech, Wales (Bennett, 1987). D, REE patterns of chert and the Mn-rich lenses at the Blue Jay mine (Chyi and others, 1984, their table 2). $E$, REE patterns for rhodochrosite nodules and associated mudstone, chert, and shale from the Inuyama district, Japan (Matsumoto, 1987). The signature of the Inuyama rhodochrosite appears to be due to contamination by, or inheritance from, the surrounding rocks, which include chert, shale, and mudstone. The pattern of the Inuyama rhodochrosite is more enriched in $\mathrm{REE}$, and has a more pronounced $\mathrm{Ce}$ anomaly, than either hydrothermal marine crusts (fig. 13B) or Buckeye rhodochrosite (fig. $7 B$ ). $F$, Sketch, not drawn to scale, showing possible evolution of the REE patterns of sediments precipitated by vent fluids that are progressively diluted with seawater. Stage 1 represents Fe-rich clays and Fe-rich oxides precipitated from cool fluids near a vent. Stages 2 and 3 represent $\mathrm{Mn}$-rich sediments associated with mounds or vents, perhaps on stage 1 deposits. Stage 4 represents $\mathrm{Mn}$-rich and $\mathrm{Mn}-\mathrm{Fe}$ oxides deposited at some distance from the mounds and includes hydrogenous nodules.

the overlying water and the underlying (and presumably suboxic) sediment and released $\mathrm{Cd}, \mathrm{Cu}, \mathrm{Ni}$, and $\mathrm{Zn}$ to both the overlying water and underlying sediment. Considering the mobility of these trace elements at the sediment-seawater interface, it is not surprising to find ferromanganese nodules enriched in $\mathrm{Co}, \mathrm{Cu}, \mathrm{Ni}$, and $\mathrm{Zn}$. Were oxic processes to have terminated in carbonates and silicates, instead of todorokite, we would still expect the deposit to contain unusually high $\mathrm{Co}, \mathrm{Ni}, \mathrm{Cu}$, and $\mathrm{Zn}$ concentrations and to have relatively low $\mathrm{Mn} / \mathrm{Fe}$. These are not the characteristics of the Buckeye deposit. 
Organic matter, incorporated in the sediment column, decomposes by a progressive series of suboxic and anoxic $\mathrm{CO}_{2}$-producing reactions that consume oxygen, reduce $\mathrm{MnO}_{2}$, form $\mathrm{N}_{2}$, reduce $\mathrm{Fe}_{2} \mathrm{O}_{3}$ (or $\mathrm{FeOOH}$ ), reduce sulfate to form sulfide, and finally form methane (Froelich and others, 1979). These reactions provide a mechanism for supplying soluble $\mathrm{Mn}^{+2}$ (and $\mathrm{Fe}^{+2}$ ) to pore fluids. These cations can then diffuse upward to the oxic zone, where they precipitate as oxyhydroxides near the top of the sediment column (Lynn and Bonatti, 1965). The intensity of reduction is favored by excess of organic matter (high biological productivity) and time: ferric oxyhydroxides will not be reduced before quadrivalent manganese oxyhydroxides and nitrate (Sawlan and Murray, 1983), and methane will not be formed before manganese, iron, and sulfate have been reduced. Thus, methanogenesis requires a supply of organic reductant that exceeds the supply of the preceding oxidizing agents. The diffusion of dissolved $\mathrm{Mn}^{+2}$ (and $\mathrm{Fe}^{+2}$ ) in response to an oxygen potential gradient is dependent upon the presence of nearby oxidized seawater. Because diffusion of $\mathrm{Mn}^{+2}$ is a relatively slow process, it is favored by slow sedimentation (and can be arrested by deposition of a thick, perhaps organic-rich, overburden that displaces the oxidizing seawater). Dymond and others (1984) identified the product of suboxic diagenesis in nodules from only one of the three Pacific sites studied and concluded that the suboxic process was intermittent and was related to pulses in the supply of organic debris. The characteristic product forms nodule bottoms, has a high $\mathrm{Mn} / \mathrm{Fe}(20-70)$, and is enriched in $\mathrm{Sb}(124 \mathrm{ppm})$ and $\mathrm{U}$ (7.7 ppm). Had suboxic diagenesis been sufficiently intense to produce sulfide or methane, ferric iron would have already been reduced, resulting in the formation of sulfide, in situ, or precipitates with smaller $\mathrm{Mn} / \mathrm{Fe}$. The Buckeye deposit offers the organic matter (debris of radiolarians) required by the suboxic model, but the model does not explain the absence of replacement features, low $\mathrm{Sb}$ and $\mathrm{U}$ concentrations, and the lack of iron-rich precipitates that would be expected, particularly if methane was produced.

Mn-rich carbonate within modern sediment columns has been discussed by Suess (1979) and by Pedersen and Price (1982). The carbonate occurs in coarse-grained or porous horizons, such as layers of volcanic ash, and the primary precipitates have spheroidal or botryoidal texture. Calvert and Price (1977) considered the carbonate activity to be the critical factor in the presence or absence of Mn-rich carbonate. In contrast, Pedersen and Price (1982) regarded a plentiful supply of (hydrogenous) manganese oxides to be more important for rhodochrosite formation than an unusual supply of dissolved carbonate. The latter opinion is important because it suggests that, following reduction and dissolution, manganese would be reprecipitated as carbonate, close to the site of original oxides. In either case, it is difficult to imagine the in-situ production of sufficient $\mathrm{Mn}$ or $\mathrm{CO}_{2}$ to produce a thick layer of rhodochrosite. Transport over great distances, exceeding that possible by diffusion alone, appears to be be necessary.

No modern diagenetic carbonate has a composition of the rhodochrosite endmember. Many recent manganiferous carbonates contain calcium (but only low concentrations of $\mathrm{Mg}$ and $\mathrm{Fe}$ ), and those of Loch Fyne, Scotland, coexist with calcium carbonate (Calvert and Price, 1970). Ancient Mn-rich carbonate and rhodochrosite, interpreted to have had an origin involving marine diagenesis, occur in the Inuyama district, Japan (Matsumoto, 1987). In most respects, Buckeye rhodochrosite is unlike Inuyama carbonate. Like the modern diagenetic $\mathrm{Mn}$-rich carbonates, Inuyama rhodochrosite is spherulitic and nodular. The Buckeye rhodochrosite is layered (and interbedded with other Mn-rich phases). There is only a small proportion of radial (tufted) or spherulitic rhodochrosite at the Buckeye, and that material clearly replaces earlier, extremely fine grained, unoriented rhodochrosite. Inuyama rhodochrosite occurs in bedded chert and has similar large $\mathrm{Mn} / \mathrm{Fe}$ but smaller concentrations of $\mathrm{Cu}$ and $\mathrm{Ni}$, much higher REE concentrations, a better developed Ce anomaly (fig. 13E), and less negative values of $\delta^{13} \mathrm{C}$.

Hydrothermal deposits precipitate from mixtures of fluids that were originally marine: fresh seawater drawn beneath the seafloor by convection; connate seawater from the sediment column; possible juvenile fluids; and more fresh seawater. As it circulates through sediments and (or) igneous rocks, the fluid is reduced (Eh potential lowered) by interaction with organic matter (see Froelich and others, 1979) and (or) ferrous-iron-bearing rocks, acidified by the removal of $\mathrm{Mg}$ to form smectitelike and talclike phases (Thornton and Seyfried, 1985), and possibly heated. This fluid leaches manganese and iron from the column of sediments and igneous rocks and transports both dissolved and suspended constituents toward the seafloor. Dilution and cooling, brought about by mixing with fresh, relatively oxidizing and alkaline, cold seawater, causes precipitation within the fracture system or near seafloor vents. These precipitates form rapidly. Manganese that does not settle to the seafloor can be greatly diluted with normal seawater (Baker and Massoth, 1986) and carried for thousands of kilometers between the seafloor and surface by buoyant fluid plumes (Klinkhammer and others, 1986). These plumes are associated with metalliferous sediments (Edmund and others, 1982; Klinkhammer and Hudson, 1986) and may be a source of hydrogenous manganese that is subsequently reworked by diagenetic processes. 
The mineralogy and chemistry of marine hydrothermal deposits are varied but distinctive. The common Mn-rich phases are birnessite and todorokite, rather than vernadite as in the hydrogenous nodules and crusts. Some hydrothermal precipitates are described as gel-like (Hoffert and others, 1978; Brett and others, 1987; Haggerty, 1987). Nontronite (see Bischoff, 1972; Corliss and others, 1978; and Alt, 1988) and talc (Lonsdale and others, 1980) are also found. Manganese and iron can be efficiently fractionated from each other in a $\mathrm{pH}$ - or an Eh-potential gradient (Krauskopf, 1957; Hem, 1972), such as might be brought about when reducing and acid solutions containing dissolved iron and manganese are progressively diluted with oxidizing and relatively alkaline seawater (see Edmund and others, 1979). Progressive dilution should result in a continuous distribution of $\mathrm{Mn} / \mathrm{Fe}$ ratios. However, most deposits considered, on the basis of close spatial association with seafloor vents that debouch fluids, to be hydrothermal have $\mathrm{Mn} / \mathrm{Fe}$ values that are either low (less than 0.1) or high (greater than 7). The relative scarcity of demonstrably hydrothermal deposits that combine low trace-element concentrations and intermediate $\mathrm{Mn} / \mathrm{Fe}$ (values of 0.1 to 10 ) may be due to inadequate sampling or absence of iron in the rising solutions. (Large $\mathrm{Mn} / \mathrm{Fe}$ values would occur if iron was precipitated as sulfides or oxyhydroxides at depth.) Alternatively, different reaction kinetics or an excess of $\mathrm{MnO}_{2}$ (relative to the supply of reducing agent) might cause manganese but not iron to be dissolved by the circulating solutions (see Thornton and Seyfried, 1985). Obviously, if iron was not taken into solution, iron-rich precipitates would not be present. Hydrothermal deposits have low concentrations of $\mathrm{Co}, \mathrm{Ni}, \mathrm{Cu}$, and $\mathrm{REE}$, no Ce anomaly relative to fresh seawater, and a flat REE pattern (fig. 13).

Hydrothermal deposits will have diverse manifestations in the geologic record. One should look for sulfide, oxyhydroxide, and silica vein systems and vents (Boyce and others, 1983; Herzig and others, 1988) that cut across sedimentary layering; Mn-rich or Fe-rich crusts that formed on the seafloor adjacent to vents (Bonatti and others, 1976) and, in the case of Mn-rich crusts, underlying sediments such as ferruginous clays that lack detrital-terrestrial, pelagic, and volcaniclastic components; or umbers on ophiolites. The hydrothermal precipitates may consist of layers and laminations that differ in composition, color, or texture. Because of their close association with fluid-filled fissures, hydrothermal vein deposits might be expected to have small lateral extent. Vented warm fluids would rise and quickly mix with fresh seawater, causing nearby precipitation. The 56$\mathrm{km}^{2}$ sheet of bedded nontronite on the floor of the Red Sea (Bischoff, 1972) is an exception, almost certainly caused by venting of hot but dense brines, thereby restricting vertical mixing with fresh seawater (and favoring lateral spreading). Long-lasting hydrothermal activity could result in a suite of deposits that record either separate hydrothermal pulses (the opening and closing of subsurface fluid conduits in response to mechanical disturbances and to blockage of channels by rapidly formed precipitates) that are progressively younger, upward, in the sediment column, or the lateral movement of the ocean floor relative to sources of heat (Crerar, 1982). Many Mn-rich deposits described as having a hydrothermal origin at or beneath the seafloor are known from midocean ridges and tectonically active areas. Their preservation may be due to rapid burial by sediments or volcanic rocks, a process that would prevent upward mobilization of manganese by diagenesis.

\section{MODERN HYDROTHERMAL ANALOGUES}

Features of the Buckeye deposit are more similar to those of hydrothermal deposits formed on the seafloor than to those of subsurface hydrothermal, hydrogenous, or diagenetic deposits (table 13). Major differences between the Buckeye and modern marine hydrothermal Mn deposits are the greater compositional and mineralogical diversity, the absence of volcanic bedrock, and the presence of chert, shale, and graywacke at the Buckeye deposit. Ironically, the best studied system at which the hydrothermal fluids interact with sediments (Guaymas Basin) does not precipitate any Mn-rich crusts, probably because of high fluid temperatures at the vents. However, other manganiferous lenses in the Franciscan Complex, long considered to have the same origin as the Buckeye deposit (Taliaferro and Hudson, 1943), are associated with basalt. Elsewhere, ancient Mn-rich lenses of apparent hydrothermal origin are intimately associated with chert. In the following paragraphs we will examine these differences and attempt to explain how they could arise from rising fluids, using as the starting point for the discussion processes operating at moundlike or ridgelike deposits that are now forming at midocean ridges.

Mounds occur $20 \mathrm{~km}$ south of the Galapagos spreading center at $86^{\circ} \mathrm{W}$. longitude. Lonsdale (1977) described their distribution and morphology. Corliss and others (1978) and Schrader and others (1980) gave mineralogical and chemical analyses of dredged samples. Physicalproperty measurements and core examinations were summarized by Dymond and others (1980), Hekinian and others (1978), Hoffert and others (1980), and Honnorez and others (1981). Galapagos mounds are steep-sided cones, 5 to $20 \mathrm{~m}$ high, aligned in chains that are presumably related to fractures in basaltic bedrock. In plan view they are similar in size to the Buckeye ore lens (25 to 100 $\mathrm{m}$ in diameter). The internal structure of a mound is 15 to $30 \mathrm{~m}$ thick, extends below the elevation of the surround- 
ing surface, and consists of nontronitic clay that overlies calcareous and siliceous nannofossil ooze and is capped with a todorokite-birnessite crust. Cores through the sediment column adjacent to the mounds revealed only nannofossil ooze. Although no fluid venting has been observed on the Galapagos mounds, the heat flow is greater through the mounds than through the surrounding flat sediments. Measured thermal gradients are not linear, and fluids 2 to $8^{\circ} \mathrm{C}$ above ambient bottom-water temperature seeped from holes punched into the mounds. These observations indicate the presence of a hydrothermal system and suggest that $\mathrm{Mn}$ (and $\mathrm{Fe}$ ) could be leached from underlying basalt and sediments by convecting fluids. The chemical signatures of the Galapagos sediments are distinctive: $\mathrm{Mn} / \mathrm{Fe}$ exceeds 82 in the $\mathrm{Mn}$ crusts, $\mathrm{Mn} / \mathrm{Fe}$ is less than 0.02 in the nontronite layers, and both materials have small concentrations of $\mathrm{Co}, \mathrm{Ni}, \mathrm{Cu}$, and $\mathrm{Th}$, as at the Buckeye. The REE patterns are also strikingly similar (compare figs. $7 B$, $13 B$ ). Thus, the Galapagos mounds, which show evidence of active hydrothermal processes, have some of the same morphological and chemical features of the depositional process recorded by the Buckeye deposit. However, the graywacke, the chert and shale, and the compositional diversity within the ore lens, all of which occur at the Buckeye, are missing from the Galapagos mounds.

Manganese-rich crusts have been dredged from the base of the median-valley scarp at the Trans Atlantic Geotraverse (TAG) site on the Mid-Atlantic Ridge (Scott and others, 1974). Crust from site 13 is composed of 5- to 10-mm-thick layers of birnessite with minor todorokite. Radiometric data indicate rapid growth of the crust, 0.1 to $0.2 \mathrm{~m} / 10^{6} \mathrm{yr}$. The chemical signature is not distinctly that of either a suboxic diagenetic or a hydrothermal process. The concentrations of Co (maximum $25 \mathrm{ppm}$ ), $\mathrm{Cu}$ (less than $119 \mathrm{ppm}$ ), and $\mathrm{Ni}$ (less than $660 \mathrm{ppm}$ ) are relatively small, and the $\mathrm{U} / \mathrm{Th}^{232}$ ratio ranges from 2.3 to 6.6. The large $\mathrm{Mn} / \mathrm{Fe}$ (the minimum value is 364 ) favors a hydrothermal process, but the concentration of $U$ ( 9 to $16 \mathrm{ppm}$ ) is larger than in other hydrothermal deposits. Ferromanganese crust with 1 - to 5-mm laminations, dredged from TAG sites $2 \mathrm{~B}$ and $10 \mathrm{G}$, had similar concentrations of $\mathrm{U}$ (11 to $18 \mathrm{ppm}$ ) but, in contrast, much smaller $\mathrm{U} / \mathrm{Th}^{232}$, suggestive of a hydrogenous process. Influenced by a small increase in the temperature of bottom water and by the presence of Fe-rich suspended particles, Scott and others (1974) concluded that the crust from site 13 was deposited by a hydrothermal spring. Klinkhammer and others (1986) revisited the area and found anomalously high temperatures (as great as $0.6{ }^{\circ} \mathrm{C}$ above ambient) and concentrations of manganese and silica in fluids collected near vents, supporting a hydrothermal origin for crust at site 13 .
Seafloor deposits in the French American Mid-Ocean Under Sea (FAMOUS) area of the Mid-Atlantic Ridge were retrieved by Hoffert and others (1978). Water samples taken near two vents showed neither a temperature nor a composition anomaly, but a thin wedge of surficial precipitate spread outward from each vent, decreasing in thickness from 1 to $0.1 \mathrm{~m}$ and covering an area of about 40 by $15 \mathrm{~m}$. The underlying sediment was fossiliferous and $\mathrm{CaCO}_{3}$-rich. Surficial materials rich in $\mathrm{Fe}$ and $\mathrm{Si}$ and composed of glauconite-celadonite and nontronite occurred near the vents, whereas $\mathrm{Fe}-\mathrm{Mn}$ oxyhydroxides lay farther from the vents. With distance, there was the following progression of materials: "gel-like inclusions of manganite, gel-todorokite, gelrancieite, birnessite-rancieite, and gel-cryptomelane" (Hoffert and others, 1981, p. 81). Some interlayering between clay-rich material and oxide-hydroxides occurred. The clays had $\mathrm{Mn} / \mathrm{Fe}$ values of 0.1 to 0.3 , low concentrations of $\mathrm{Co}, \mathrm{Ni}$, and $\mathrm{Cu}$, and $\mathrm{Co} / \mathrm{Zn}$ values less than 2 , thereby falling into the Fe-rich hydrothermal category. The $\mathrm{Mn}$-rich materials had $\mathrm{Mn} / \mathrm{Fe}$ values of 2 to 3 , like many hydrogenous and diagenetic deposits, but had lower concentrations of $\mathrm{Co}, \mathrm{Ni}, \mathrm{Cu}$, and $\mathrm{Zn}$ than oxic diagenetic or hydrogenous deposits. Because of their association with vents and ferruginous clays, we favor an origin involving hydrothermal over suboxic-diagenetic processes. Perhaps these Mn-rich materials are samples of the intermediate stage in the fractionation path between $\mathrm{Fe}$-rich and $\mathrm{Mn}$-rich hydrothermal precipitates. In contrast, basalts collected some distance from the vents are covered with $\mathrm{Fe}$-rich crusts. These coatings have $\mathrm{Mn} / \mathrm{Fe}$ values of 0.3 to 0.5 , high concentrations of $\mathrm{Co}, \mathrm{Ni}$, and $\mathrm{Cu}$, and a $\mathrm{Co} / \mathrm{Zn}$ of 5.7 to 8.2. This different chemical signature reflects hydrogenous or oxicdiagenetic processes. Although the composition of the crusts found adjacent to the vents is too Fe-rich to be a good analogue for the Buckeye, the FAMOUS site demonstrates that hydrothermal processes develop tabular (almost lenslike) bodies, form gel-like materials, and develop compositional diversity by fractionation on a very local scale.

Recently, a new mounds field has been discovered in the Mariana back-arc basin. Some observations may bear upon the origin of deposits such as the Buckeye. Leinen and others (1987) reported that the Mariana mounds are associated with high heat flow and faults, have morphologies ranging from cones $2 \mathrm{~m}$ high to hummocks half that height, and are associated with finely laminated sediments. Leinen and others (1987) also related the formation of nontronite to a supply of biogenic silica. Fluid advects from the centers of the mounds over a distance of $30 \mathrm{~m}$ (Leinen and others, 1987; Wheat and McDuff, 1987; Dadey and Leinen, 1987). Although we do not discount the importance of precipitation at the seawater-sediment 
interface, lateral flow parallel to sediment laminations provides a mechanism for distributing additional fluxes while preserving earlier formed layers of contrasting composition.

Vents in the Guaymas Basin, on the northern extension of the East Pacific Rise (EPR), debouch hydrothermal fluids that interacted with a thick sedimentary pile after leaving the presumed basaltic basement (Von Damm and others, 1985). The sediments in the southern trough consisted of siliceous skeletal debris and detrital clays but, unlike the Buckeye deposit, had 10 to 15 percent $\mathrm{CaCO}_{3}$. The $\mathrm{Mn}$ content of the solutions was not as great as at the sediment-starved ridge vents, presumably because the vented solutions were alkaline and with $\mathrm{pH}$ of 6.5, due to dissolution of $\mathrm{CaCO}_{3}$ and decomposition of organic matter to produce $\mathrm{NH}_{3}$. Nevertheless, reported Mn concentrations exceed those of seawater by a factor of $10^{4}$, and Lonsdale and others (1980) found surficial Mn-rich crusts on talc in the northern trough of the basin. All $\mathrm{Mg}$ and sulfate could be attributed to mixing or contamination with fresh seawater, but the appreciable $\mathrm{H}_{2} \mathrm{~S}$ content suggests that degradation of organic matter was more than sufficient to mobilize $\mathrm{Fe}^{+2}$ and that ferrous iron sulfide should have precipitated at depth. Vent temperatures exceeded $250^{\circ} \mathrm{C}$. Bowers and others (1985) modeled both the interaction of hot EPR fluids with Guaymas sediment at $315^{\circ} \mathrm{C}$ and the mixing of $315^{\circ} \mathrm{C}$ Guaymas vent fluid with fresh, cold seawater. The calculations were not carried to temperatures lower than $5{ }^{\circ} \mathrm{C}$, corresponding to fluid mixtures containing less than 1 percent of the original hydrothermal component. Quartz, talc, sulfides, and smectite were the dominant precipitates, and the oxygen fugacity did not increase sufficiently to precipitate quadrivalent Mn oxides. Bowers and others did not, unfortunately, consider the interaction of fresh seawater with sediments alone, particularly calcium-carbonate-free sediments, as occur at the Buckeye. Campbell and others (1988) found that, upon dilution, dissolved $\mathrm{Mn}$ emitted from Guaymas vents precipitated within 1 week (or within several kilometers) and settled, contributing to the $\mathrm{Mn}$ anomaly in the surface sediments.

Data for the REE-enriched hydrogenous nodules and crusts abound, but REE analyses of the relatively depleted hydrothermal deposits, modern or ancient, are scarce. Preliminary analysis suggests that three characteristics of the REE patterns can be correlated with the nature of the mineralizing process (table 13). Relative to seawater, the REE patterns of hydrothermal oxyhydroxides and clays are less evolved-depleted and flatthan are patterns of hydrogenous materials (fig. 13A). Examination of REE patterns for a variety of materials from modern deposits (figs. $13 A, B$ ) suggests that a Ce anomaly can develop without appreciable overall enrich- ment and that, even in the region in which enriched patterns overlap, the hydrogenous patterns show a depletion of heavy REE whereas the hydrothermal patterns are relatively flat. These observations suggest the following progression of features with increasing degree of REE enrichment (fig. 13F). The first characteristic to develop is the Ce anomaly (pattern 2), which becomes distinct before appreciable overall enrichment in REE (pattern 3). The last characteristic to develop is the depletion in heavy $\mathrm{REE}$ (pattern 4) relative to the intermediate REE (pattern 3). This last pattern probably develops long after the third stage and may be the result of diagenetic as well as hydrogenous processes. The earlier stages of this sequence correspond to the progressive dilution of the vented fluids. Comparison of figures $7 A$ and $13 E$ suggests that the Buckeye protoliths have characteristics that are little evolved relative to seawater and plankton and that are similar to patterns from hydrothermal materials.

It is clear that, although no modern analogue for the Buckeye deposit has been found, marine hydrothermal deposits record some of the fluxes that were previously proposed for the Buckeye. Further, the late-stage and highly fractionating hydrothermal processes in the marine environment record some of the geochemical signatures that were found in the Buckeye protoliths. Sources for two of the sedimentary fluxes (dissolved Mn, $\mathrm{Si}$ ) are found in the venting solutions at the modern deposits. At vent sites that have no siliceous sediments, the dissolved silica is precipitated as iron-bearing clays, late in the progressive mixing of vented fluids and seawater. At the Guaymas Basin, where hot fluid interacts with a siliceous sediment column that is thicker than the chert-rich section at the Buckeye, quartz is a major product of precipitation. Perhaps, were the solutions cooler or in contact with siliceous sediment for a shorter time, late-stage $\mathrm{Mn}$ silicates might precipitate before the $\mathrm{Mn}$ is oxidized and precipitated as oxyhydroxides. Fresh seawater, a possible source of $\mathrm{O}_{2}$ to precipitate hausmannite and braunite and of $\mathrm{Mg}$ necessary for $\mathrm{Mg}$-rich chlorite and $\mathrm{Mg}$-substituted caryopilite, is ubiquitous near the vents. Missing from the modern hydrothermal environments is direct evidence for the dissolved- $\mathrm{CO}_{2}$ flux, although measured high values of alkalinity and $\mathrm{pH}$ (Von Damm and others, 1985) are suggestive of its presence. Carbon-dioxide species must have been present in the modern systems because skeletal $\mathrm{CaCO}_{3}$ is present in some sediments and because diagenetic processes make $\mathrm{HCO}_{3}^{-}$available to the solutions during all stages of the oxidation of organic matter (Froelich and others, 1979). As in the case involving a deficiency of dissolved silica to precipitate $\mathrm{Mn}$ silicates, a higher concentration of dissolved $\mathrm{CO}_{2}$ is needed to precipitate 
$\mathrm{Mn}$ as $\mathrm{MnCO}_{3}$ before quadrivalent oxides. Perhaps abundant siliceous turbidites, such as those at the Buckeye, can provide both.

Were siliceous ooze to be abundant in the modern mounds-forming environments, in which cool fluids are vented, there could be three important chemical differences. (1) The siliceous skeletal debris could provide soluble opaline silica to form the $\mathrm{Mn}$-silicate protoliths-the gel-like materials and clays of caryopilite, taneyamalite, and gageite compositions. (Without the source of easily soluble silica, hot solutions would be necessary to dissolve silica from silicates in basalt in the sediment column.) (2) Abundant organic debris would decompose and ultimately be oxidized to $\mathrm{HCO}_{3}^{-}$or $\mathrm{CO}_{2}$, providing the dissolved carbonate necessary to precipitate rhodochrosite. (3) A consequence of the decomposition of organic matter and $\mathrm{CO}_{2}$ generation is the consumption of dissolved oxygen in fresh seawater to produce fluids with intermediate to low redox potentials. These reduced fluids would stabilize $\mathrm{Mn}^{+2}$ ions so that Mn could be dissolved and transported from sediments and (or) basalt. Progressive dilution with fresh seawater at the vent would reverse the process by increasing the alkalinity and Eh of the fluids, causing rhodochrosite, hausmannite, braunite, and $\mathrm{Mn}$-silicates to precipitate. Pulses in the flux of silica and organic matter, caused by nearby turbidites of radiolarian sand that occurred at the Buckeye, provide one possible mechanism for developing layers and laminations with strong compositional contrast. Each turbidity flow would immediately disturb the fluids near the seawater-sediment interface, more slowly influence the dissolved silica concentrations, and ultimately, through diagenetic processes, influence the fluids that contribute to the supply of $\mathrm{Mn}$ and $\mathrm{CO}_{2}$. No modern deposits of rhythmically interbedded chert and shale protoliths are known (Hein and Parrish, 1987), with or without hydrothermal precipitates. A clue to their occurrence might be the association of a zone with very high productivity of siliceous pelagic organisms, seafloor vents that discharge cool fluids, and a seafloor that lies below the carbonate compensation depth.

\section{SOME POSSIBLE ANCIENT ANALOGUES}

Many manganese-rich deposits occur in the geologic record. A review of some of these deposits, particularly those associated with interbedded chert and shale, may provide additional clues for the origin of the Buckeye deposit. Because none of these deposits is as little metamorphosed as the Buckeye, their mineral associations or assemblages differ from those of both the modern deposits and the Buckeye. In the following paragraphs we will discuss how the Buckeye protoliths might change with increasing metamorphic grade and discover that some metamorphosed deposits record original features that are similar to sedimentary features recorded by the Buckeye.

\section{PROJECTED METAMORPHIC PATH}

Manganiferous sediments that have been subjected to metamorphic temperatures greater than those experienced by the Buckeye deposit should develop distinctive suites of $\mathrm{Mn}$-rich minerals. Many possible minerals are included in the compilation (table 1). Of this list, the minerals that will actually be present depend as much upon the bulk composition of the manganese deposit as upon metamorphic grade. In the case of the Buckeye, $\mathrm{Mn}, \mathrm{Si}, \mathrm{C}, \mathrm{O}, \mathrm{H}$, and perhaps $\mathrm{Al}$ and $\mathrm{Mg}$ are the controlling elements. The minerals most likely to form include tephroite, pyroxmangite, spessartine, bixbyite, chlorite, and perhaps the rare Mn-chlorites, pennantite and gonyerite. Tephroite and pyroxenoids will form at the margins of the lens by reactions involving rhodochrosite and chert (Huebner, 1967). Under appropriate conditions and suitably high $f \mathrm{H}_{2} \mathrm{O}$ and $f \mathrm{~F}_{2}$ (or low $f \mathrm{CO}_{2}$ ), the humite-group minerals sonolite, manganhumite, and alleghanyite might appear. We suspect that these minerals are more common than has been previously recognized. The scarcity of $\mathrm{MgO}$ and $\mathrm{FeO}$ in the Buckeye deposit is not conducive to the formation of amphiboles (tirodite-dannemorite). The paucity of $\mathrm{Na}_{2} \mathrm{O}, \mathrm{MgO}$, and Fe would severely limit the appearance of pyroxenesdonpeacorite, kanoite, johannsenite, or the unnamed $\mathrm{NaMn}^{+3} \mathrm{Si}_{2} \mathrm{O}_{6}$ found by Ashley (1986) and by Lucchetti and others (1988)-and the amphibole kozulite. The scarcity of $\mathrm{CaO}, \mathrm{Al}_{2} \mathrm{O}_{3}$, and $\mathrm{Na}_{2} \mathrm{O}$ make the formation of akatoreite, piemontite, the manganese pumpellyites, carpholite, and most hydrous pyroxenoids unlikely. Thus, a consequence of a restricted bulk composition is that the chemically simple phases should persist over a wide range of metamorphic conditions. At the Buckeye, much of the braunite, hausmannite, and rhodochrosite should persist to higher metamorphic grades.

Huebner $(1967,1976)$ predicted that, with increasing temperature and $f \mathrm{CO}_{2}$ sufficient to stabilize rhodochrosite, $\mathrm{fO}_{2}$ would fall or maintain a relatively constant value but would not rise. There would be a series of decarbonation reactions by which protoliths of rhodochrosite, hausmannite, braunite, and quartz would react to assemblages that contain tephroite and (or) a pyroxenoid. Bixbyite or quadrivalent oxides would not appear unless the protolith was more highly oxidized than at the Buckeye.

The caryopilite, taneyamalite, and gageite protoliths, which were not originally considered by Huebner (1967, 1976), plot very near the $\mathrm{Mn}-\mathrm{Si}$ join, shown in 


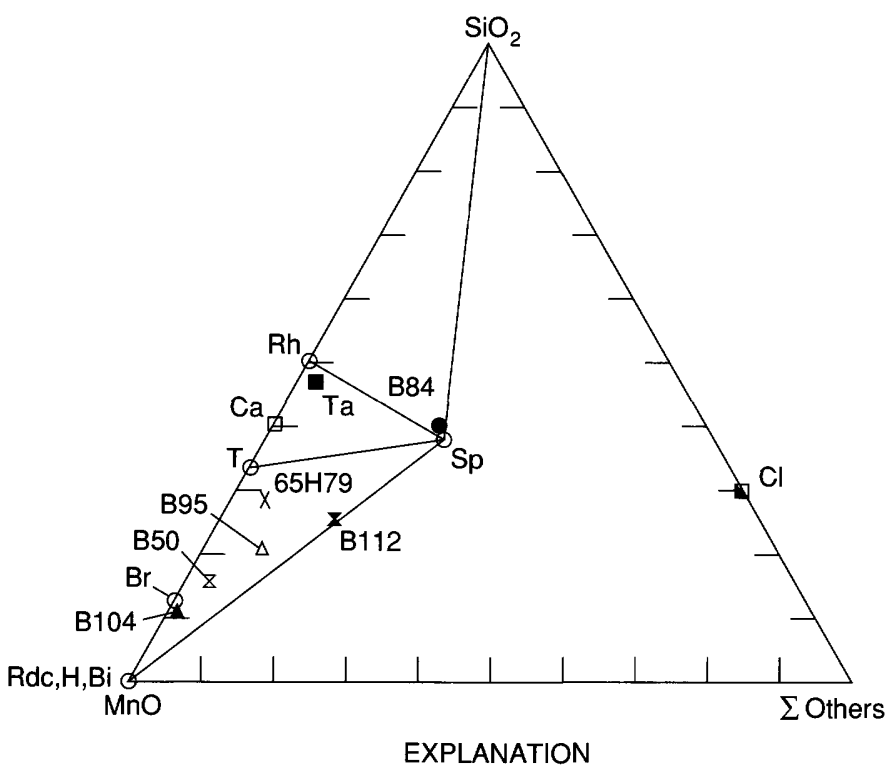

Ideal compositions

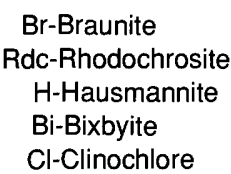

$A$

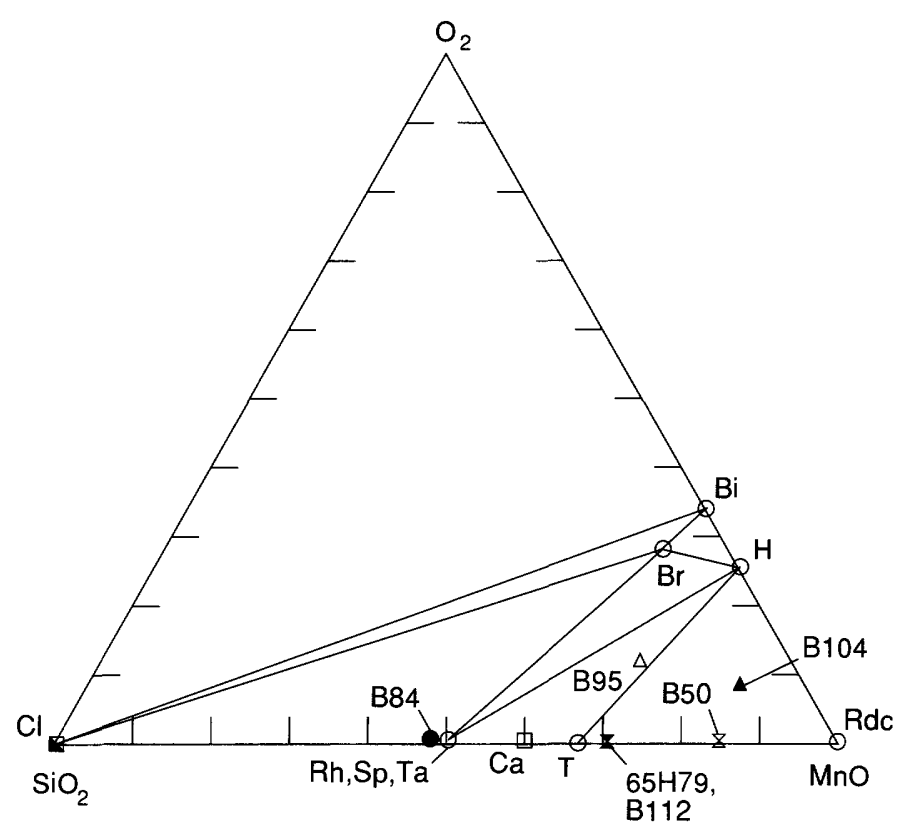

EXPLANATION

Ideal compositions:

Rh-Rhodonite
Sp-Spessartine
Ca-Caryopilite
T-Tephroite
Ta-Taneyamalite

Br-Braunite

Rdc-Rhodochrosite

H-Hausmannite

Bi-Bixbyite

Cl-Clinochlore

$B$

Figure 14. - Predicted greenschist-facies assemblages for Buckeye protoliths in which the principal Others components are $\mathrm{Al}_{2} \mathrm{O}_{3}$ and $\mathrm{MgO}$ in chlorite and gel of chlorite composition. Sample numbers refer to analyzed protoliths (table 6). $A$, Projection from $\mathrm{O}_{2}, \mathrm{CO}_{2}$, and $\mathrm{H}_{2} \mathrm{O}$ onto the plane $\mathrm{MnO}-\mathrm{SiO}_{2}-\Sigma$ Others. This diagram is suitable for silicate-rich and carbonate-rich protoliths in which most manganese is divalent. Mole percent. Symbols for protolith samples are the same as in figure $9 D$. $B$, Projection onto the plane $\mathrm{MnO}-\mathrm{SiO}_{2}-\mathrm{O}_{2}$ from all other components. This diagram is suitable for protoliths rich in hausmannite, braunite, or bixbyite. The anticipated metamorphic assemblages involve tephroite, rhodonite, and spessartine, in addition to the low-temperature phases braunite, hausmannite, rhodochrosite, and quartz, which will persist to high metamorphic grade. Because there are so few minerals in chemically simple systems such as those at the Buckeye, these metamorphic assemblages should persist over a range of conditions. Assemblages involving spessartine and one of the oxides, hausmannite, braunite, or bixbyite, are unlikely because chlorite does not occur in the "oxidized" protoliths.
$\mathrm{MnO}-\mathrm{SiO}_{2}-\mathrm{O}_{2}$ and $\mathrm{MnO}-\mathrm{SiO}_{2}-\Sigma$ Others projections (fig. 14). A gageite-rich protolith, represented by $65 \mathrm{H} 79$, might transform to a mixture of hausmannite, tephroite, and vapor at relatively high $f \mathrm{O}_{2}$ but, if the ambient $f \mathrm{CO}_{2}$ was sufficiently high, rhodochrosite would take the place of hausmannite. A carbonate-gageite protolith such as B50 would also yield carbonate, tephroite, and perhaps hausmannite. Caryopilite-rich protolith, represented by B84 (caryopilite-carbonate-chlorite), should react to carbonate, tephroite, spessartine, and vapor. Our caryopilite-carbonate protolith (B112) would yield the same minerals, but in different proportions. Were the protolith very caryopilite-rich, pyroxmangite would be a reaction product. Because the manganese in these assemblages is predominantly divalent, braunite would not appear. More oxidized layers, represented by a braunite-rich protolith such as B95, would form a tephroite-hausmannite or tephroite-carbonate assemblage if $\mathrm{O}_{2}$ were free to leave the system, but if $f_{2}$ remained constant, braunite could persist to higher temperatures. Hausmannite is more reduced and stable at higher temperatures, so a hausmannite-rich protolith, represented by B104, would retain most of its lowtemperature characteristics, with only minor amounts of tephroite forming from admixed caryopilite and gageite. The sodium in taneyamalite might stabilize nambulite, saneroite, or serandite. We think that because $\mathrm{CaO}$ is low in the Buckeye protoliths, the pyroxenoid might be 
pyroxmangite, but rhodonite would be a more likely product of metamorphosing santaclaraite-rich veins or horizons.

With increasing metamorphic grade, the possible assemblages that could form are severely limited by the restricted bulk composition of the Buckeye ores and other Mn-rich deposits. The variety of Mn minerals (table 1) reported from $\mathrm{Mn}$ deposits metamorphosed to greenschist and amphibolite grades reflects, in large part, the availability of elements that are found in only low amounts or are essentially absent at the Buckeye.

\section{ORIGINS OF ANCIENT DEPOSITS}

Of the deposits that might have an origin similar to that of the Buckeye, few rival its diversity of Mn-rich lithologies, and most others include lithologies that are chemically distinct. To identify deposits formed in similar environments, we must not ignore deposits composed of fewer protoliths than at the Buckeye or deposits that contain significant additional chemical components, perhaps reflected in new lithologies. Unfortunately, few of our predecessors described the combination of geologic setting and compositions of individual layers that will be necessary to identify true analogues. In the following paragraphs we will summarize critical features of some possible analogues to the Buckeye deposit (and features of some deposits that are not suitable analogues). The analogues have a worldwide distribution. Like the Buckeye, many appear to have their origins in a chert-forming marine environment.

The Smith prospect, Sierra Nevada Foothills, Nevada County, Calif. (I.F. Wilson, in Trask, 1950, p. 167-168; Hewett and others, 1961; Huebner, 1967; Flohr and Huebner, 1988), lies in a belt of chert, slate, mafic igneous rocks, and graded crystal tuffs of probable marine origin. The deposit is a lens of rhodochrosite and laminated hausmannite enveloped by massive white to gray chert. Metamorphic minerals are rhodonite, tephroite, and small amounts of spessartine and sonolite; their occurrence is controlled by local bulk composition. At least some of the rhodonite is a reaction product between carbonate and chert (Huebner, 1967). Interbedded chert and metashales are nearby. Huebner noted the occurrence of pyrite crystals and "colorless to brown glass...incipiently recrystallized to a platey yellow silicate with $7 \AA$ spacing" (p. 75). The "glass" may correspond to the gel-like material of chlorite composition found at the Buckeye, and the pyrite may signify reduction of seawater sulfate to form sulfide. Spessartine occurs with rhodonite and chert, but not hausmannite, much as chlorite layers at the Buckeye avoid the more oxidized assemblages. The area contains serpentine and mafic volcanic rocks of zeolite- or lower greenschist- facies grade. It is clear that tephroite and rhodonite can form at very low metamorphic grades. We expect the compositions of the protoliths at the Smith prospect to have higher $\mathrm{CaO}$ contents but otherwise to resemble the compositions reported for the Buckeye (table 6). Huebner (1967) advocated an origin for the Smith deposit that involved thermal springs. We see no reason to discount the connection between manganese deposition and a hydrothermal ore-forming system driven by an igneous heat source at the Smith prospect.

The setting of the Manga-Chrome mine is similar to that of the Smith prospect, which lies three miles to the south (I.F. Wilson, in Trask, 1950; Hewett and others, 1961; Flohr and Huebner, 1988). We examined a suite of tephroite-bearing samples, one of which is shown by Hewett and others (1961, their fig. 1). These specimens show sedimentary layers and laminations on a scale similar to that of the Buckeye protoliths. The layers consisted of rhodochrosite, the material called neotocite by Hewett and others (1961), but which is probably gel-like material of chlorite composition, and hausmannite-rich metasediment. Some tephroite forms layers parallel to bedding and may represent metamorphosed gageite-rich layers. We expect that the composition of these sediments would resemble those of the Buckeye protoliths. A metamorphosed volcanic fragment sits in laminated carbonate-rich mud, suggesting a close spatial association between volcanism and deposition of manganese-rich sediments.

Manganiferous metasediments at the Hoskins mine, New South Wales, Australia (Ashley, 1986) lie between ferruginous metachert (compositionally similar to a mixture of chert and $\mathrm{Al}$-poor nontronite) and overlying metasiltstone and metasandstone. The metachert overlies metabasalt of MORB (midocean-ridge basalt) composition and probable greenschist-facies metamorphic grade. This suite was deposited on the seafloor of the Cowra trough. Ashley compared the contorted and brecciated laminations with those of jasper at the Blue Jay and South Thomas mines, Franciscan Complex (Crerar and others, 1982); we would extend the comparison to deformed protoliths at the Buckeye deposit. The jasper grades into massive manganese-rich metasediment that now contains tephroite and rhodonite with minor hausmannite, Mn-rich chlorite, Mn-rich garnet, and relic manganoan calcite and quartz. Texturally and compositionally laminated Mn-rich sediment in which much $\mathrm{Mn}$ and all $\mathrm{Fe}$ are trivalent may overlie the massive ore. The minerals include braunite, manganoan pectolite, amphibole (near kozulite in composition), an unnamed $\mathrm{Mn}^{+3}$ analogue of acmite, and an Mn-rich micaceous phase. The compositions of Mn-rich metasediments at the Hoskins mine are similar to compositions of the Buckeye protoliths but have slightly higher concentrations of $\mathrm{Al}_{2} \mathrm{O}_{3}$, 
$\mathrm{Fe}_{2} \mathrm{O}_{3}$, and $\mathrm{CaO}$ and significantly higher concentrations of alkalis and the trace elements $\mathrm{Ba}, \mathrm{Co}$, and $\mathrm{Sr}$. The two Mn-rich metasediments at Hoskins can be distinguished by the higher As and lower $\mathrm{Co}, \mathrm{Cu}, \mathrm{Sr}$, and $\mathrm{Zn}$ in the massive ore. Ashley (1986) proposed an origin in which laminated silica and iron hydroxide gels were overlaid by mounds of $\mathrm{Mn}$-carbonate, Mn-oxides and hydroxides, and silica that were deposited near vents. The possibility of Mn-silicate protoliths was not discussed. Possible precursors for the laminated ore, suggested by Ashley solely on the basis of the chemistry of the layers, include alkali feldspar or alkali-silicate gel; clays; oxides and hydroxides incorporating $\mathrm{Mn}, \mathrm{Ba}$, and $\mathrm{K}$; barite; and $\mathrm{Ca}-\mathrm{Ba}-\mathrm{Mn}$ carbonates. Perhaps caryopilite should be added to his list.

Deposits in the Ashio mountainland, Japan, best reveal the geology of the bedded manganese deposits in the Chichibu geosyncline, Japan (Watanabe and others, 1970). These deposits are stratiform and occur with thin-bedded and massive cherts and basic volcanic rocks. The amount of Mn ore correlates with that of associated massive chert. The primary precipitates include rhodochrosite, hausmannite, bementite, and "siliceous material represented by colloidal silica" (Watanabe and others, 1970 , p. 139). This material may correspond to the relic gel-like material found at the Buckeye. Regional metamorphism resulted in braunite, tephroite, rhodonite, spessartine, and piemontite. The conformably bedded and mineralogically diverse deposits described by Watanabe and others (1970) are more similar to the Buckeye deposit than are the spherulitic rhodochrosite nodules of purported diagenetic origin from the Inuyama district, Japan, described by Matsumoto (1987).

Banded and massive manganese deposits are associated with chert-basalt contacts in the Apennine ophiolites (Bonatti and others, 1976). Base-metal deposits occur in the basalts. The manganese deposits are contained in layered chert, some of which is radiolarite, 20 to $30 \mathrm{~m}$ above the basalt. Limestone and calcareous shale, but not graywacke, succeed the chert. Iron-rich sediments (Fe-oxides, ferruginous chert, or argillite) are absent; the authors attributed this absence to the early removal of iron (as sulfide) from a hydrothermal system. Banded manganese deposits are stratiform and contain layers of Mn minerals interbedded with red chert at a thickness scale of $1 \mathrm{~cm}$. Massive deposits the size of the Buckeye lenses occur at the hinges of folds, are brecciated, and grade laterally into banded deposits. Braunite is the principal manganese mineral; it is commonly accompanied by traces of rhodochrosite, parsettensite, chlorite, rhodonite, and piemontite. As is the case with the Buckeye ores, the bulk compositions of the Apennine ores fall close to the join $\mathrm{Mn}^{+2} \mathrm{Mn}_{6}^{+3} \mathrm{SiO}_{12}-\mathrm{SiO}_{2}$, with minor $\mathrm{Fe}, \mathrm{Al}, \mathrm{Mg}$, $\mathrm{Ti}$, and alkali contained in nonmanga- niferous silicates. The $\mathrm{Mn} / \mathrm{Fe}$ and $\mathrm{U} / \mathrm{Th}$ values are large and the concentrations of $\mathrm{Cu}$ and $\mathrm{Ni}$ are small. The $\mathrm{Co}$ concentration (11-600 ppm range), although higher than in most deposits thought to have a hydrothermal origin, is distinctly lower than in typical hydrogenous deposits. Bonatti and others (1976) presented two REE patterns that are puzzling even when the labeling of their table 7 is made to conform with their figure 6 and text. The seawater-normalized pattern (fig. 13C) for a brauniterich sample is depleted like the Buckeye carbonates but has a well-developed (and unique) negative Ce anomaly; the mid-range is flat. The chert is depleted overall. Bonatti and others (1976) proposed that the $\mathrm{Mn}$ was deposited as a sedimentary precipitate and that the observed mineralogy developed during subsequent metamorphism. We think that the Apennine deposits demonstrate several sedimentary precipitates with an origin related to volcanism and hydrothermal processes. The similarity of the Apennine and Buckeye deposits suggests that the Buckeye may also have had a hydrothermal origin.

The Blue Jay (Trinity County) and South Thomas (Mendocino County) deposits in the Franciscan Complex, California, are deposits that may also be analogous to the Buckeye deposit. Crerar and others (1982) described massive Mn-rich lenses in thinly bedded chert that is underlain by basalt. Crerar and others (1982) did not report massive chert, but I.F. Wilson (in Trask, 1950, p. 138-139) noted the presence of massive white chert at the South Thomas mine. At the Blue Jay mine, sandstone occurs in contact with both chert and basalt (Crittenden, in Trask, 1950, p. 308). Crerar and others (1982) referred to the ore as massive but reported few results of a thin-section examination of the ore. We have found that even the most massive hand specimens of Buckeye braunite and hausmannite are laminated when examined as polished thin sections, and we suspect that the braunite from the Blue Jay and South Thomas mines would also prove to be laminated, were it so examined. Trask and Trauger (in Trask, 1950, p. 309-310) mentioned only hausmannite, carbonate, bementite, and native copper in the ore from the Blue Jay mine. Crerar and others (1982) identified braunite and minor rhodochrosite, hausmannite, bementite, neotocite, rhodonite, inesite, pyrolusite, todorokite, birnessite, nsutite, and vernadite, but they found that much of the Mn-rich material was so poorly crystallized that it could not be characterized. Traceelement data were given by Crerar and others (1982) and Chyi and others (1984). In many respects, the analyses are comparable to those of an average Buckeye composition. The ores have high $\mathrm{Mn} / \mathrm{Fe}$ and $\mathrm{U} / \mathrm{Th}$, and low concentrations of $\mathrm{Al}$ and $\mathrm{Ti}$, but Buckeye values for $\mathrm{Zn}$ are higher and for $\mathrm{Cu}$ lower. Most REE patterns (fig. 
$13 D$ ) show little overall enrichment and relatively flat slopes, similar to patterns for the Buckeye and the modern hydrothermal materials, but it is puzzling that the two most REE-enriched samples have the smallest Ce anomaly. The REE patterns for most of the cherts are similar to those of the most enriched cherts at the Buckeye. Clearly, there are morphological, mineralogical, and chemical similarities among these three deposits. As in the case of the Apennine deposits decribed by Bonatti (1976), the similarity of Blue Jay, South Thomas, and Buckeye deposits suggests processes associated with seafloor volcanism and hydrothermal activity.

Compared with $\mathrm{Mn}$ deposits in the Franciscan Complex, stratabound Mn-rich lenses of Northland and Auckland, New Zealand, have similar lenticular shape but are smaller and lack associated massive chert (Stanaway and others, 1978, p. 24). Associated rock types are interbedded cherts and argillites, marbles, submarine lavas and tuffs, massive sulfide lenses, and ferromanganese deposits. The Mn-rich laminae and lenses consist of hausmannite, braunite, bementite, and manganite but not carbonate. Stanaway and others (1978) invoked diagenetic unmixing and recrystallization of sedimentary Mn-rich clay precipitates under alkaline conditions to develop the observed coarser textures and colloform structures. The $\mathrm{Mn} / \mathrm{Fe}$ values and trace-element concentrations for most primary deposits in Auckland are similar to those for the Buckeye deposits, but silica is lower and alkali higher. Stanaway and others (1978) regarded the primary ferromanganese precipitates as having been amorphous and now best represented by the cores of oolites. These New Zealand deposits demonstrate a close association with volcanic processes and textural diversity that increases with diagenetic reprocessing. Three stages of marine hydrothermal ore formation may be represented: early sulfide formation, Fe precipitation, and late $\mathrm{Mn}$ precipitation. The Buckeye deposit records only the stage of $\mathrm{Mn}$ precipitation. Further, postdepositional processes such as diagenesis do not appear to have been important at the Buckeye.

Other stratiform and banded manganese formations with mineralogy similar to that of the Buckeye lack the close association with chert and have lateral dimensions that greatly exceed those of the Buckeye lenses. The Hotazel Formation in the Kalahari Basin, South Africa, contains Mn-rich sediments (braunite, hausmannite, bementite, traces of rhodochrosite) and banded ironformation (De Villiers, 1970; Kleyenstuber, 1984). Volcanic shards (in the Mn sediments), silicified rock, jasper, and andesitic volcanic rocks, but not graywacke, are present. Kleyenstuber advocated a volcanogenicsedimentary origin. Unlike the Buckeye, the Hotazel has no interbedded chert-metashale sequences. The lateral extent of individual manganiferous horizons (more than
$35 \mathrm{~km}$ ) exceeds that found in most modern marine analogue environments (basins, rifts) or that of the Ladd-Buckeye district. Thus the ore-forming process must have been capable of delivering tremendous quantities of $\mathrm{Mn}$ and dispersing it throughout an entire basin.

Banded greenschist-facies metasediments of Harlech, Wales, form a 40-cm-thick horizon that covers an area of $190 \mathrm{~km}^{2}$ and correlates with quartz-spessartine metapelite horizons located $30 \mathrm{~km}$ to the west (Bennett, 1987). The Harlech Mn-rich horizon extends throughout the area and consists of Mn-rich carbonate, spessartine, chlorite, and silica. We think that the Harlech protoliths could have been composed of $\mathrm{Mn}$-carbonate, $\mathrm{Mg}$-chlorite, and quartz or of taneyamalite and $\mathrm{Mg}$-chlorite (see fig. 14). The mean trace-element concentrations (Mohr, 1956; Bennett, 1987) are similar to those of modern hydrothermal precipitates (table 13). The REE patterns (Bennett, 1987), converted to our seawater-normalized scheme (fig. $13 C$ ), resemble Buckeye patterns. Red laminated ore shows the greatest REE enrichment, consistent with the aluminosilicate fraction. The pattern of yellow concretionary ore, now composed largely of carbonate, spessartine, quartz, and chlorite, closely resembles the pattern for the caryopilite-carbonate protolith at the Buckeye (fig. $7 B, \mathrm{~B} 112$ ). Caryopilite and carbonate are reasonable protoliths for the observed mineral association of the yellow layers at Harlech. Microspherulitic ore is reported to be composed of carbonate, but the REE patterns are more enriched than those of Buckeye rhodochrosite. Perhaps this distinction can be attributed to the opaque phase, presumably a $\mathrm{Mn}$-oxide, that is evident in Bennett's photomicrograph (1987, his fig. 7C). The "average carbonate" (Bennett, 1987, p. 13) is not described. Like Buckeye carbonate, it has low concentrations of REE. Like Buckeye gageite, the Harlech carbonate is enriched in the heavy rare-earth elements $\mathrm{Yb}$ and $\mathrm{Lu}$. Perhaps Harlech carbonate had a protolith consisting of rhodochrosite and gageite. As in the case of the Hotazel deposits, the Mn-rich sediments of Harlech have similarities to the Buckeye deposit and its modern analogues, but the rhythmic cherts are lacking and the areal extent is larger. Needed is a process to introduce $\mathrm{Mn}$ and to disperse it over an area of $190 \mathrm{~km}^{2}$. Bennett (1987) proposed that this process was the precipitation of oxides or, less probably, carbonates directly from a hydrothermal brine. Were this brine to be denser than cold seawater and to spread laterally to fill a basin, as at the Red Sea (see Bischoff, 1972, his fig. 2), Mn could be spread over an area the size of the Harlech or Kalahari Mn-rich horizons.

We conclude this section by noting that there may be more than one environment for the formation of protoliths that in some way resemble those found at the Buckeye deposit. However, the themes of hydrothermal 
activity and volcanism are common to descriptions of both modern seafloor deposits and ancient deposits that might, before diagenesis and (or) metamorphism, have had similar protoliths. Lacking is a consistent set of chemical and isotopic observations that can be uniformly applied to all deposits. In many cases, we are not confident that the reported mineralogy is complete or correct. Most serious is the almost total lack of petrographic data on internal structures that might help distinguish primary sedimentary processes from diagenetic and metamorphic processes. We urge future workers to sample these deposits on the scale of the original sedimentary units and to present petrographic data in addition to chemical data.

\section{ORIGIN OF BUGKEYE DEPOSIT}

The foregoing descriptions provide clues to the nature of the environment in which the Buckeye deposit formed and to the processes of manganese concentration and precipitation that might have operated in that environment. By extension, other manganiferous lenses in the Franciscan Complex may have similar origins. We will summarize the local environment, discuss the combination of processes that we believe was responsible for $\mathrm{Mn}$ deposition, then move on to discuss the regional geologic frameworks that might permit the operation of these processes.

\section{ENVIRONMENT NEAR BUCKEYE DEPOSIT}

The association of conglomerate, graywacke and shale, chert, and manganiferous units to form a thick unit (the Grummett broken formation) appears to be caused by primary sedimentary processes rather than secondary tectonic juxtaposition. Radiolarian cherts are marine, occur in orogenic belt sequences (Hein and Karl, 1983), and are deposited in environments that are isolated from coarse terrigenous clastic material such as that which would form graywackes. Although it would be convenient to call upon tectonic processes to juxtapose the chert and graywacke, no field evidence supports this idea. The Buckeye deposit apparently formed in an environment that permitted the alternation of chertforming and graywacke-forming processes.

There is evidence for a high-energy distant environment and a low-energy nearby environment. The occurrence of thick graywacke units coupled with the coarse basal(?) conglomerate and intraformational shale-chip conglomerate further indicate that one environment had high potential energy, such as might be provided by a continental slope, walls of a rift valley, or slopes leading outward from a midocean ridge or into a trench. The lateral continuity of the thin chert beds and interbedded metashales, which are uniform over at least the scale of outcrop, indicates the presence of a second environment with low potential energy that had a gently sloping or flat seafloor, perhaps in the form of a small, shallow basin.

The high-energy environment provided differentiated plutonic components (alkali feldspar, quartz, volcanic clasts), ultramafic and mafic components (chromite, chlorite), chert, and lithified but not recrystallized sediments (shale chips). The source must have been distant and exposed a cross section including recent sediments, differentiated igneous rocks, and ultramafic to mafic basement. The ribbon cherts, representing the nearby low-energy environment, contain two components. One is clearly local in origin and consists of the debris of siliceous pelagic organisms, which accumulated on the ocean floor and periodically flowed into the site of manganese deposition. The second component is represented by the fine, claylike material that formed the metashale interbeds and mixed with the accumulating debris of organisms to form the included "dust" and thin partings in the cherts. The similarity between the average $\mathrm{TiO}_{2}, \mathrm{Al}_{2} \mathrm{O}_{3}$, and alkali contents of seven metashales from the Ladd-Buckeye district (the argillites of Hein and others, 1987) and averages for metashales (Pettijohn, 1957) and graywacke (Pettijohn, 1963) suggests that the source material for the metashales was detrital, perhaps fine detritus related to the graywacke. This is confirmed by the REE patterns, which mimic those of the graywackes (fig. 7A). Deposition of the metashales was probably continuous, forming a background that was periodically overwhelmed (diluted) by a turbidity flow or deposition of a manganese lens.

The combined lack of current structures, algal structures, bioturbation, and calcareous fossils together with the preservation of delicate laminae suggests deposition in deep water, consistent with the topography necessary to accelerate the turbidites. The depth of the seafloor is not known; the absence of calcareous skeletal debris and the relatively low concentrations of $\mathrm{CaO}$ in the ores and surrounding sediments suggests deposition below the carbonate compensation depth (or, conversely, suggests that there were no pelagic calcium-secreting organisms). The abundance of radiolarian chert suggests oceanic upwelling that enriches surface waters in nutrients (Hein and Parrish, 1987). Because even hot solutions vented at the seafloor have been observed to move laterally rather than reach the surface of the ocean (Klinkhammer and others, 1986; Baker and Massoth, 1986), it seems unlikely that there would be a direct connection between fluids vented at the ocean floor and a pelagic bloom near the surface. 


\section{MANGANESE DEPOSITION AT BUCKEYE DEPOSIT}

Traditional interpretation of the origin of deposits such as the Buckeye involved inorganic hydrothermal processes that culminated in thermal springs and precipitates on the ocean floor. Recently Hein and others (1987) and Hein and Koski (1987) invoked organic diagenesis at depth that culminated in the replacement of chert by manganese carbonate within the sediment pile. This model provides a plausible explanation for the source (quadrivalent Mn oxyhydroxides in the sediment column) and solubilization (reduction to $\mathrm{Mn}^{+2}$ state) of the manganese. It also provides a mechanism (methanogenesis and subsequent oxidation to $\mathrm{CO}_{2}$ ) for generating carbonate that is strongly depleted in ${ }^{13} \mathrm{C}$. An origin involving only diagenesis and replacement, however, is not compatible with all features at the Buckeye deposit. Our principal objections to a model based on diagenesis and replacement are the following.

(1) Despite the large number and diversity of samples examined, we observed no islands of relic (unreplaced) chert. (2) There is evidence that Mn was removed from, not introduced into, the chert at the margin of the orebody. (3) We observed no cases in which the orebody transected the layering of the surrounding chert. (4) The scale at which most of the ore is laminated is finer than the scale of layering within the chert and metashale. (5) There is a large halo of $\mathrm{Mn}$ enrichment, rather than $\mathrm{Mn}$ depletion, surrounding the orebody. The $\mathrm{MnO}$ content decreases from an average of about 50 weight percent in the orebody to about 5 weight percent in the adjacent wallrocks drilled by Volin and Matson (1949). Average values for different lithologies in the series chertmetashale from the Ladd-Buckeye district range from 0.21 to 1.29 weight percent $\mathrm{MnO}$ and 1.20 to 8.57 weight percent total iron as $\mathrm{Fe}_{2} \mathrm{O}_{3}$ (Hein and others, 1987). Compared with broader scale averages (Pettijohn, 1957; Cressman, 1962), these materials appear enriched, not depleted, in MnO. Additional analyses (Huebner and Flohr, unpub. data) of chert and shale from the vicinity of the Buckeye deposit confirm the $\mathrm{MnO}$ enrichment. The $\mathrm{MnO}$ concentrations of seven graywackes range from 0.02 to 0.74 weight percent and thus, overall, appear enriched rather than depleted in MnO (compare with Pettijohn, 1957, 1963; Taylor and McLennan, 1985). (6) According to the model, silica replaced by rhodochrosite contributed to the formation of massive chert (Hein and others, 1987, p. 220). However, the so-called massive chert is thinly layered (bedded). The displaced silica has not been found. (7) The model does not provide a mechanism to form layers of six to nine distinct compositions in the orebody. Further, the massive chert and interbedded chert and metashale lack the lithologic (compositional or textural) diversity of the orebody, making it unlikely that the observed layering in the orebody reflects layering of some precursor. (8) Gel-like materials occur in the orebody, yet we would not expect such fine-grained materials to form during the replacement of chert and shale or to survive burial diagenesis in a wet, warm environment. (9) The spherulitic and botryoidal textures ascribed by others to precipitation of rhodochrosite during diagenesis are rare at the Buckeye and, where they do occur, clearly replace earlier, very fine grained rhodochrosite. (10) The Mn protoliths, including the Mn-silicates, have depleted REE patterns, relative to those of the chert and metashale (fig. 7). Claylike silicates formed by replacement inherit the traceelement signatures of their precursors (Mosser, 1979; Mosser and others, 1979). If the Mn protoliths, including the silicates, formed by replacement, we would expect less-depleted REE patterns. (11) The orebody and surrounding graywackes are sulfide poor, yet the suggested diagenetic reactions would have brought together dissolved $\mathrm{Fe}^{+2}$ and $\mathrm{H}_{2} \mathrm{~S}^{-}$to precipitate $\mathrm{FeS}_{2}$. (12) Diagenesis of organic matter produces methane only after all ferric iron is reduced to soluble $\mathrm{Fe}^{+2}$. Thus, in the absence of a sink for iron (precipitation as sulfides), the model fails to explain the high $\mathrm{Mn} / \mathrm{Fe}$ observed in the orebody. (13) The model calls for zones of Mn reduction and oxidation, separated by a zone of diffusion. Such a process should result in a single $\mathrm{Mn}$-rich layer or single set of $\mathrm{Mn}$-rich layers, one of each protolith. It is difficult to imagine a diffusion process at depth that will produce cyclically alternating compositions, such as the carbonate and caryopilite observed at the Buckeye. Were the oxic zone raised, the zone of $\mathrm{Mn}$ precipitates should be dissolved and reprecipitated at a higher level. There is no petrographic evidence for such a shift in position. (14) It is unlikely that diffusion alone would be the mechanism for scavenging $\mathrm{Mn}$ from the surrounding volume of chert, metashale, and graywacke. Considering the distances involved (the zone of Mn enrichment extends hundreds of meters), it is probable that moving fluids played an important part in transporting the manganese. (15) The diagenetic model accounts for the absence of modern deposits like the Buckeye by having them form beneath the seafloor but does not explain the absence of modern equivalents of the associated interbedded cherts and metashales, which must have formed on the ocean floor. Until the modern environment for deposition of interbedded chert and shale is found, the modern environment for deposition of a Buckeye deposit cannot have been found.

Our model, based on a cool hydrothermal system, combines diagenesis to dissolve the manganese incorporated in the sediment column, fluid flow to transport the $\mathrm{Mn}$, and precipitation at the seafloor to develop the fine laminations and diversity of compositions. These processes will be discussed in the sequence in which they interact with fluid in the sediment pile. 
Oxic and mildly suboxic diagenesis occurs near the top of the sediment column. This process consumes buried organic matter using, as an oxidant, oxygen that is dissolved in the pore fluid, that is bound to quadrivalent $\mathrm{Mn}$, or that diffuses (as molecular $\mathrm{O}_{2}$ ) downward from the water column. The $\mathrm{Mn}^{+2}$ produced is dissolved in the pore fluid. Some $\mathrm{CO}_{2}$ dissolves to form $\mathrm{H}_{2} \mathrm{CO}_{3}$ and $\mathrm{HCO}_{3}^{-}$. At the same time, the fluid equilibrates with opaline skeletal debris, taking some silica into solution. Deeper in the sediment column, intensely suboxic and anoxic conditions occur, but any $\mathrm{Fe}^{+2}, \mathrm{H}_{2} \mathrm{~S}^{-}$, and $\mathrm{CH}_{4}$ produced under these conditions are precipitated in place or, if they migrate upward, oxidized and perhaps precipitated before they reach the upper levels. The oxidants are carried by fluids that pass through the sediment column. Iron is precipitated as oxyhydroxide (or sulfide), $\mathrm{HS}^{-}$is converted back to $\mathrm{SO}_{4}^{-2}$, and $\mathrm{CH}_{4}$ is oxidized to $\mathrm{CO}_{2}$ with negative $\delta^{13} \mathrm{C}$ before reaching the mildly suboxic and oxic zones. Some $\mathrm{CO}_{2}$ and $\mathrm{CH}_{4}$ may move as vapor bubbles. An important element of the diagenetic portion of the model is that any anoxic fluids are neutralized (made mildly suboxic) by interaction with oxic to suboxic fluid-either slightly modified seawater that circulates beneath the seafloor or pore fluids expelled by compaction from deeper and less organic-rich (or less reactive) sediments. The results are a supply of aqueous fluid carrying dissolved species of $\mathrm{Mn}, \mathrm{CO}_{2}$, and $\mathrm{SiO}_{2}$, the absence of sulfides, and Fe-poor precipitates, as observed at the Buckeye deposit.

The source of the manganese is enigmatic. Mafic volcanic rocks, which appear in models for seafloor mounds, are not part of the stratigraphic column at the Buckeye, although such volcanic rocks are spatially associated with many other manganese deposits in the Franciscan Complex. The most likely source of manganese is the sediment column, including the interbedded chert-metashale, as in the diagenesis model of Hein and Koski (1987), or the graywacke, from which manganese could be leached and transported in the divalent state by relatively reducing solutions. The source sediment could lie below the deposit or be laterally displaced from it. The source might even be a lithology that is not represented in the Grummett broken formation.

Dissolved constituents, and perhaps included vapor bubbles, were transported by fluids that flowed within the sediment column and vented at the seafloor. The forces driving the fluids were heat and (or) pressure. Heat would cause convection that draws fresh, oxygenated seawater into the sediment column; favored passageways would be channels that open to the seafloor. As a result of sediment compaction, pressure would expel fluids into channels and upward toward the seafloor. In a tectonically active environment, such as that in which the Buckeye formed, semiconsolidated and consolidated sed- iments would be expected to have been fractured and to influence fluid flow at higher levels, much as fractures in sediment-covered basalts are thought to influence the distribution of mounds and vents near midocean ridges. Fractures, ranging from the quartz- and carbonatebearing shear zones that separate broken formations (fig. $1 B$ ) to veins that cross $\mathrm{Mn}$-rich sediments but do not deposit Mn minerals (figs. $4 A, E, J$ ) are evidence that moving fluids were channeled. In one case (fig. $4 A$, B87), hausmannite-rich layers became more carbonate rich near the vein, suggesting that the vein fluid had lower redox potential than the original sediment and was $\mathrm{CO}_{2}$-rich. Fluid flow permitted scavenging of $\mathrm{Mn}$ from distances greater than diffusion fields, separation of the anoxic region of methane generation from that of ore precipitation, and rapid delivery of ore-forming constituents. The ephemeral nature of vein systems, which open and close in response to tectonic disturbances, subsidence, and precipitation, provides a means for quickly turning the supply of ore-forming constituents on and off, leading to groups of orebodies, each with sharp boundaries against the enclosing cherts.

Mixing of fluid from within the sediment column with fresh seawater and subsequent precipitation on the seafloor satisfies many of the observed constraints. There will be no residues-as phases or chemical signatures-of a replaced lithology. Because the composition of the mixed fluid will vary with the composition of the subsurface fluid, the flow rate of the vented fluid, and the degree of mixing with fresh seawater, the nature of the precipitated layers may change with time or distance from the vent and may show cyclical variation, and the layers may be thick or thin. The model permits rapid delivery of ore-forming materials, necessary to avoid contamination (terrestrial, hydrogenous, or diagenetic), and rapid precipitation from the fluid mixture, necessary to localize the deposit.

Changes in the fluxes supplying chemical components to the depositional site varied and caused compositional layering within the orebody. These variations must have been rapid, perhaps on the scale of seasonal climatic variations that, through winds, affected the upwelling of nutrients and that have been shown to affect the rates at which diatom tests are supplied to the seafloor (Honjo, 1982; Takahashi, 1986). Fluids from the sediment column probably provided fluxes of dissolved $\mathrm{Mn}, \mathrm{SiO}_{2}, \mathrm{CO}_{2}$, and minor to trace amounts of the "hydrothermal" elements such as $\mathrm{Zn}$. Seawater probably contributed fluxes of $\mathrm{O}_{2}$, $\mathrm{MgO}$, and minor and trace amounts of $\mathrm{Ba}, \mathrm{Mo}, \mathrm{V}$, and $\mathrm{SO}_{4}$. The composition of the seawater itself may have varied, particularly with respect to dissolved $\mathrm{O}_{2}$, which could vary seasonally. Thus, the valence of $\mathrm{Mn}$ in individual protoliths, and the Ce anomaly, could depend not 
only on the ratio of fluids in the mixture but upon the composition of the seawater component.

\section{DIAGENESIS AND METAMORPHISM}

The relatively oxidized sediments $\left(\mathrm{Mn}^{+3}\right.$ is present) were preserved rather than subsequently modified by diagenesis. Had the Mn-rich precipitates experienced suboxic diagenesis after burial, braunite, and perhaps hausmannite, would not have survived. We presume that little organic matter was buried with the Mn-rich and surrounding sediments or, if present, that it was isolated from the deposit.

Our observations provide seemingly contradictory evidence for the existence of a fluid phase during diagenesis and metamorphism. By analogy with modern marine sediments, we presume the initial graywacke sands, cherts, shales, and Mn-rich layers were very water rich. Veins of quartz, aragonite, and calcite clearly mark fluid pathways. However, the non-uniform distribution of jadeite within the Grummett broken formation, the presence of relic gel-like materials within the orebody, and the preservation of oxidized Mn (in braunite) suggest the absence of a fluid phase that would promote recrystallization or regional redox equilibrium. To reconcile these observations, we propose that compaction during burial and subsidence expelled most of the trapped pore fluids throughout the section, leaving relatively dry (and thus unreactive) materials, such as chert. Subsequent fluid loss at metamorphic pressures was concentrated along the contacts between the broken formations, at some distance from the Buckeye orebody. These contacts were kept open to fluid loss by shearing, which appears to have been sufficiently intense, in some cases, to transport dense blocks of glaucophane-bearing schists. Fluid in these shear zones may ultimately have reached seafloor vents. Higher metamorphic temperatures at greater depths may have caused decomposition of the clay- and chlorite-rich matrix of the metagraywackes, providing an additional source of fluids.

The Mn-rich mineralogy at the Buckeye provides a clear record of high oxygen-fugacity values during metamorphism. The occurrences of braunite and hausmannite clearly record an intrinsic oxygen fugacity that is orders of magnitude greater than that of the surrounding graywackes (Huebner, 1967, 1976), which contain ferrous silicates (table 5) and, probably, organic matter. Because this $f \mathrm{O}_{2}$ is so high, it cannot have been brought about by metamorphic equilibration with surrounding rocks and must reflect the premetamorphic history of the sedimentary environment (Huebner, 1967). Huebner (1969, p. 476) suggested that there might be oxidation halos surrounding such highly oxidized orebodies. In the case of the Buckeye, the surrounding interbedded chert and metashale are highly oxidized, but this state is probably a primary rather than a secondary feature. It is more difficult to read the metamorphic temperatures and pressures. One difficulty is the absence, in the Buckeye deposit, of mineral associations that can be proven to be equilibrium assemblages. By analogy with howieite, which is thought to be stable only at high pressure and low temperature (Lattard and Schreyer, 1981), the occurrence of the mineral taneyamalite might indicate high pressures of formation. Calculations by Huebner (1967) indicated that the partial pressure of $\mathrm{CO}_{2}$ at the stage recorded by the mineralogy was an order of magnitude less than the total pressure estimated from the mineral assemblages in the metagraywacke. Either no fluid phase was present or the fluid was dilute with respect to $\mathrm{CO}_{2}$. At such high $\mathrm{fO}_{2}$ values and equilibrium, $\mathrm{CO}, \mathrm{CH}_{4}$, and $\mathrm{H}_{2}$ would not be abundant species. Therefore, any fluid present during metamorphism must have been aqueous. But preservation of relic gel-like materials suggests that an aqueous phase was not present during metamorphism and therefore that no fluid was present.

\section{REGIONAL FRAMEWORK}

The spatial and temporal relations between the sites of Mn deposition and deep burial (blueschist-facies metamorphism) are enigmatic. Convecting fluid, even cool water, requires a heat source, yet rapid subsidence that generates 5-8 kbar pressure without exceeding 150-200 ${ }^{\circ} \mathrm{C}$ requires a small regional thermal gradient. If the Buckeye Mn lenses were precipitated from fluids driven by a heat source, it must have been highly localized, decayed before subduction, or moved relative to the lenses. However, if manganese and $\mathrm{CO}_{2}$ were dissolved in, transported by, and precipitated from fluids expelled by compaction of the sediment pile, it is conceivable that no heat source would be necessary.

\section{POSSIBLE ENVIRONMENTS}

Mn-rich mounds have been observed to form in oceanic island arcs and oceanic spreading centers, where they are associated with high heat flow and nearby hot or warm fluids. If cooler fluids can leach manganese and iron from the sediment column, Mn-rich mounds might occur in two additional environments. One is the abyssal floor at great distance from the midocean ridge. Here, hemipelagic sediments should be underlain by mafic and ultramafic ocean crust. Were serpentinization and other alteration processes not completed in the crust-forming ridge environment, they would continue, albeit at much lower temperatures, as the crust moved away from the ridge, releasing sufficient heat to drive fluid convection 
and causing an increase in rock volume (Fyfe, 1974). This volume increase might fracture the overlying sediments, thereby channelling fluids. In the geologic record, these deposits would be found associated with hemipelagic sediments but, unless subsequently juxtaposed by tectonics, probably not with graywacke turbidites. Another environment is the top of a subduction complex. Waterrich sediments in the trench (or surficial expression of the subduction complex) would release cool pore water as they were subducted. The boundaries between slabs of sediments would serve as channels for escaping fluids. Vents or chains of vents might occur on the walls of the trench. If cool fluids are able to leach manganese from the sediments, mounded deposits of Mn-rich precipitates might form on the trench walls.

In which paleoenvironment were the Buckeye deposit and related sediments of the Grummett broken formation deposited? Raymond (1974, p. 145) originally proposed that the Franciscan rocks of the Mount Oso area were deposited in an environment characterized by "a combined trench-abyssal ocean-floor plus ocean ridge." Subsequently (Raymond, 1977) he associated the manganiferous sediments with seafloor spreading centers. Snyder (1978) reviewed the literature on manganese deposits associated with chert-greenstone complexes, including deposits in the Franciscan Complex, and chose environments in which oceanic hot springs could form: oceanic spreading centers, marginal oceans, and the base of island arcs and oceanic islands. Crerar and others (1982) favored an oceanic spreading center over island arcs, back-arc spreading centers, and convergent plate margins. Hein and others (1987) interpreted the Franciscan sediments of the Ladd-Buckeye district as having been deposited near a continental margin, then made reference to possible fore-arc, back-arc, and rifted continental margin settings. Subsequently, Hein and Koski (1987) advocated a deep, rapidly deposited continental margin facies, such as the Yolla Bolly terrane of northern California described by Blake and others (1982). Raymond (1988) disagreed with the analogy because it refers to chert-poor lithologies, whereas the Grummett broken formation is chert rich.

To choose the most appropriate environment, we need first to review the facts that serve as boundary conditions for the range of possible environments. (1) The cobble conglomerate exposed near the base of the Grummett unit must have been derived from an environment with substantial topographic relief and must have been deposited relatively near its source. (2) There must have been three or four sources for the clastic sediments and pathways by which detritus could move from each source to the depositional environment. (3) These sources supplied quartz-rich but lithic-fragment-poor sands. (4) The boundaries between conglomerate, metagraywacke, interbedded chert and metashale, and the manganese deposit are primary sedimentary contacts. Thus, the depositional environment must be capable of generating these four basic lithologies in a continuous stratigraphic section. (5) The chert layers are turbidites that were deposited in an environment that was intermittently exposed to a supply of coarse detritus. (6) The manganese deposit has the size, morphology, and trace-element composition of a deposit that is genetically associated with a seafloor vent. (7) The compositional layering of the orebody signifies an environment in which the depositional parameters changed frequently. (8) Mn deposits such as the Buckeye are invariably associated with chert and shale. Mn deposits are not enclosed in graywacke. (9) Some Mn deposits, unlike the Buckeye, are associated with basalt. (10) The metagraywacke and enclosed sediments at the Buckeye were together subjected to the high pressures and low temperatures characteristic of subduction complexes at continental margins. Given these boundary conditions, we can eliminate two environments.

The abyssal floor model is unsuitable. Unlike the environment in which the Buckeye formed, the abyssal environment has low topographic relief and lies far from possible sources of the cobble conglomerate and quartzrich graywacke. Although possible sources of heat are mantle hot spots or serpentinization of heretofore unaltered oceanic crust, serpentinization is unlikely. Were this process to operate, fluids convecting through the sediment pile must have supplied the $\mathrm{H}_{2} \mathrm{O}$ necessary for serpentinization and, by association, become alkaline (high $\mathrm{pH}$ ). Such fluids would be too alkaline to leach and transport manganese and iron (Barnes and O'Neil, 1969). Thus, even though the ocean crust with its mantle of abyssal sediments might be carried into a subduction complex, the crust is unlikely to arrive with manganese deposits such as the Buckeye.

Deposition of manganese within the trench is an appealing hypothesis because it directly involves the subduction complex and provides a mechanism for bringing together sediments of diverse origins. We postulate two variations on the model associated with trenches. In the first, the fluid-expulsion model, compaction within the pile forces Mn-bearing fluids upward along shear zones between subducted slices of terrane. Because the dominant lithology is graywacke and the observed shear zones are in graywacke, we would expect at least some deposition of Mn-rich lenses on graywacke sands. The fact that the Mn-lenses are invariably associated with chert, a minor lithology, contraindicates the first mechanism. Further, the model also fails to explain the presence of submarine basalts, which underlie the cherts that are associated with many Mn lenses in the Franciscan Complex and elsewhere. If the Buckeye formed by 
the same set of processes that formed the Mn deposits that are closely associated with basalt, the model in which fluids were expelled by compaction is also inappropriate for the Buckeye deposit.

The second trench-related hypothesis involves the subduction of a midocean ridge at a continental margin. A possible modern example is the collision of the Chile Rise with the Peru-Chile trench (see Forsythe and others, 1986). In this model, the continental margin is a region of oceanic upwelling that brings nutrient-rich waters to the surface and causes high organic productivity (radiolarians). As the ridge (with its grabenlike topography) approaches the trench, chert and shale are deposited in protected basins, either directly on ridge basalt or on graywacke. Graywacke sands and conglomerate, derived from dissected, quartz-rich continental crust, flow into the trench and periodically spill into protected basins on the oceanic side of the trench axis, blanketing all other lithologies. Some coarse conglomerates and graywackes are locally derived from trench walls that oversteepen and collapse. The distal portions of both locally derived and distant flows provide a continuous supply of fine detritus that settles slowly to form shale. Shale deposition is frequently overwhelmed by flows of sands derived from the sites where the debris of radiolarians settles. Thus, the scene is set for $\mathrm{Mn}$ deposition on chert that can be both closely associated with, and distant from, basalt. Residual heat from the decaying ridge or from short-lived, near-trench thermal events (predicted by DeLong and Fox, 1978) drives fluid circulation that leaches, transports, and deposits $\mathrm{Mn}$ by the processes previously discussed. The residual heat is, in most cases, insufficient for continued basaltic magmatism. Some fluid could also be driven by expulsion from the sediment pile. Subduction buries the Mn deposit and may tectonically dissociate the $\mathrm{Mn}$ mounds or lenses (and their host rocks) from oceanic basement and crust formed at the ridge.

To be acceptable for the Buckeye deposit, the ridgetrench model must be compatible with the evolution of what is now western California. Schweikert and Cowan (1975), Dickinson and others (1982), Ingersoll (1982), and Seiders and Blome (1988), who drew upon numerous earlier studies, provide useful summaries. In Middle Jurassic time, there existed a west-facing continentalmargin arc and, to the west, an east-facing oceanic arc. Farther to the west, there must have been a spreading center (source of oceanic crust) such as the back-arc spreading center of Ingersoll (1982). By Late Jurassic to Early Cretaceous time (the dates of microfossils within the Grummett broken formation), the oceanic crust between the two arcs had been subducted, leaving the single westward-facing Sierran-Klamath magmatic arc complex, trench, and remnant of the spreading
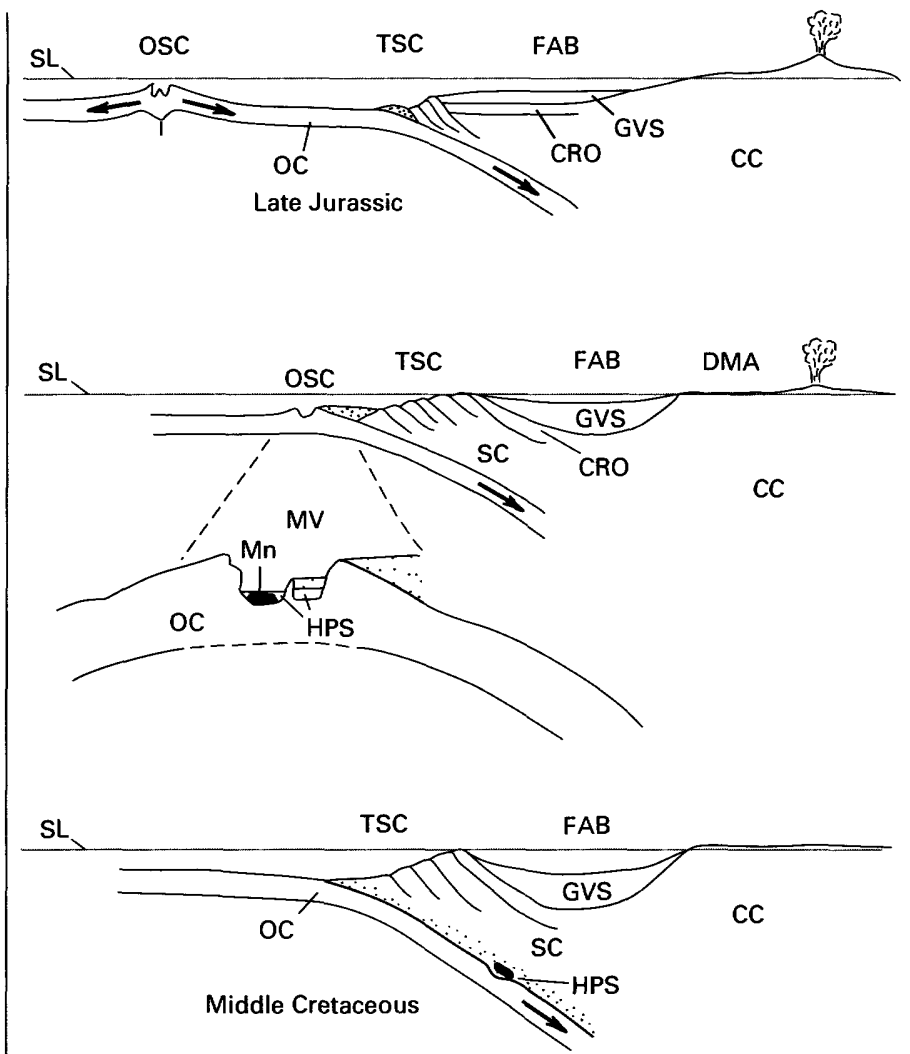

FIGURE 15.-Possible mechanism for the creation of the paleodepositional environment for the Buckeye protoliths, adapted from Dickinson and others (1982) and Ingersoll (1982) with embellishments. Drawn not to scale but to emphasize features of the depositional environment. During the Late Jurassic, an oceanic spreading center (OSC) with median valley containing restricted basins approached the continental margin, a source of quartz-bearing sands. The spreading center was consumed by subduction by Early Cretaceous time. If the spreading center was still warm as it approached the trench and subduction complex (TSC), hydrothermal Mn-rich deposits (Mn, black), and hemipelagic sediments (HPS, cherts and shales) could form near the continental margin, perhaps in locally sheltered basins or along remnants of the median valley (MV). Turbidity flows of sand, originally derived from the dissected Sierran-Klamath magmatic arc (DMA), flowed longitudinally northward along the axis of the trench and fanned outward, forming massive graywackes (stippled). Episodically, major sand-laden currents overflowed the restricted basins, permitting the stratal interlayering of hemipelagic sediments and graywackes. Other abbreviations: SL (sea level); GVS (Great Valley sequence) deposited on CRO (Coast Range ophiolite); OC and CC (oceanic and continental crust, respectively); FAB (forearc basin); SC (subduction complex).

center (fig. 15). The Great Valley sequence was deposited in the forearc basin immediately to the west of the eroded arc complex. Farther westward, Franciscan sediments flowed both westward and longitudinally from the south. These sediments were deposited along (and fanned westward from) the break in slope formed where the eastern trench slope and the oceanic crust met. At the same time, oceanic crust east of the remnant spreading center was consumed by the trough-subduction 
complex, bringing the spreading center toward the trench. If the spreading center was still warm as it approached the trench, or if fluids were expelled from the sediment pile, the scene was set for operation of the ridge-trench model as outlined above. Manganese deposits and cherts, some but not all associated with basalt, formed. Subsidence and deep burial deformed the sediments, expelled fluids, and caused the blueschist-facies overprint.

\section{SUMMARY AND FUTURE WORK}

Textural, mineralogical, microchemical, and traceelement data collected from similar (and spatially related) metasediments from the Buckeye deposit suggest that manganese carbonate, silicates, and oxides were deposited at the seafloor from dilute mixtures of hydrothermal fluid with seawater. Although similar deposits have been described in the literature, our data focus on well-characterized individual sedimentary layers rather than on individual mineral grains within a layer or on groups of layers. The chemistries of the individual layers and laminations record fluctuations in the marine environment, caused in part by periodic flows of radiolarian sand. At the Buckeye, the contrasting layer compositions record eight sedimentary components, which must contain valuable clues to the geochemical and sedimentological variables in both ancient and active marine environments. No doubt other manganese deposits formed in a similar environment, but to our knowledge the Buckeye is the only described deposit that reveals more than one $\mathrm{Mn}$-silicate protolith. The apparent uniqueness of the Buckeye is probably due more to the inadequacies of available descriptions than to any singularity in the geologic record. It is also possible that similar deposits are forming on the seafloor today.

We need to be certain that the reasoning leading to the characterization of $\mathrm{Mn}$-forming environments and processes does not become circular. Especially frail is the path of reasoning (1) chert and layered manganese deposits that are closely associated with basalt are volcanogenic, (2) therefore most chert and layered manganese deposits, even those not associated with basalt, have a volcanogenic origin, and (3) a particular layered manganese deposit formed by volcanogenic processes. The discovery and characterization of actively forming, laterally restricted volcanogenic-hydrothermal $\mathrm{Mn}$-oxide deposits has done much to strengthen the reasoning, but interbedded manganese oxides, silicates, and carbonates have not yet been found in modern environments, and laterally extensive deposits occur in the geologic record. Until we know why these ancient layered deposits differ from the actively forming deposits, we cannot be certain that the depositional environments are similar.
Detailed studies of the Buckeye deposit provide a basis for two research directions, now being undertaken. (1) We are attempting to characterize the chemical signature of each sedimentary component in order to verify the sources of each of the chemical constituents and to discover the nature and causes of the variations in the seafloor environment. In particular, we want to develop criteria that will enable us to distinguish between mafic igneous rocks and the sediment column as sources of manganese, iron, and base metals, and we want to make firm our hypothesis concerning the role of biogenic silica. We hope that the results of this effort will help us understand the origin of laterally extensive stratiform manganiferous sheets that are not associated with chert. (2) We are using petrographic and microchemical criteria, developed with reference to the Buckeye deposit, to determine the protoliths of deposits that have lost their obvious primary characteristics due to pervasive metamorphism. If correctly read, such deposits may be valuable paleoenvironmental indicators in high-grade metamorphic terranes.

\section{REFERENCES}

Adachi, Mamoru, Yamamoto, Koshi, and Sugisaki, Ryuichi, 1986, Hydrothermal chert and associated siliceous rocks from the northern Pacific: Their geological significance as indication of ocean ridge activity: Sedimentary Geology, v. 47, p. 125-148.

Albee, A.L., and Ray, L., 1970, Correction factors for electron probe microanalysis of silicates, oxides, carbonates, phosphates, and sulfates: Analytical Chemistry, v. 42, p. 1408-1414.

Alt, J.C., 1988, Hydrothermal oxide and nontronite deposits on seamounts in the eastern Pacific: Marine Geology, v. 81, p. 227-239.

Ashley, P.M., 1986, An unusual manganese silicate occurrence at the Hoskins mine, Grenfell district, New South Wales: Australian Journal of Earth Sciences, v. 33, p. 443-456.

Audley-Charles, M.G., 1965, A geochemical study of Cretaceous ferromanganiferous sedimentary rocks from Timor: Geochimica et Cosmochimica Acta, v. 29, p. 1153-1173.

Baedecker, P.A., ed., 1987, Methods for geochemical analysis: U.S. Geological Survey Bulletin 1770, $132 \mathrm{p}$.

Bailey, E.H., Irwin, W.P., and Jones, D.L., 1964, Franciscan and related rocks and their significance in the geology of western California: California Division of Mines and Geology Bulletin 183, $177 \mathrm{p}$.

Bailey, S.W., 1980, Structures of layer silicates, in Brindley, G.W., and Brown, G., eds., Crystal structures of clay minerals and their X-ray identification: Mineralogical Society [London] Monograph 5, p. 1-123.

Baker, E.T., and Massoth, G.J., 1986, Hydrothermal plume measurements: A regional perspective: Science, v. 234 , p. $980-982$.

Barnes, Ivan, and O'Neil, J.R., 1969, The relationship between fluids in some fresh alpine-type ultramafics and possible modern serpentinization, western United States: Geological Society of America Bulletin, v. 80, p. 1947-1960.

Baudracco-Gritti, Celestine, 1985, Substitution du manganèse bivalent par du calcium dans les minéraux du groupe: braunite, neltnerite, 
sediment composition in diagenesis and low-grade metamorphism of marine clay: Geological Society of America Bulletin, v. 96, p. $1287-1295$.

Toth, J.R., 1980, Deposition of submarine crusts rich in manganese and iron: Geological Society of America Bulletin, v. 91, p. 44-54.

Trask, P.D., 1950, Geologic description of the manganese deposits of California: California Division of Mines Bulletin 152, $378 \mathrm{p}$.

Trask, P.D., Wilson, I.F., and Simons, F.S., 1943, Manganese deposits of California - a summary report (including tabulated data on manganese properties of California): California Division of Mines Bulletin 125, p. 51-215.

Trengrove, R.R., 1960, Reconnaissance of California manganese deposits: U.S. Bureau of Mines Report of Investigations 5579, 46 p.

Volin, M.E., and Matson, E.J., 1949, Investigation of the Buckeye manganese deposits, Stanislaus County, Calif.: U.S. Bureau of Mines Report of Investigations 4560, [16] p.

Vonderhaar, D.L., McMurtry, G.M., Fryer, P., and Malahoff, A., 1987, Geochemistry of hydrothermal deposits from active submarine volcanoes in the Mariana arc: Eos, v. 68, p. 1533.

Von Damm, K.L., Edmond, J.M., Measures, C.I., and Grant, B., 1985,
Chemistry of submarine hydrothermal solutions at Guaymas Basin, Gulf of California: Geochimica et Cosmochimica Acta, v. 49, p. 2221-2237.

Watanabe, Takeo, Yui, Shunzo, and Kato, Akira, 1970, Bedded manganese deposits in Japan, a review, in Tatsumi, T., ed., Volcanism and ore genesis: Tokyo, University of Tokyo Press, p. 119-142.

Westerlund, S.F.G., Anderson, L.G., Hall, P.O.J., Iverfeldt, Åke, Rutgers van der Loeff, M.M., and Sundby, Bjørn, 1986, Benthic fluxes of cadmium, copper, nickel, zinc and lead in the coastal environment: Geochimica et Cosmochimica Acta, v. 50, p. 1289-1296.

Wheat, C.G., and McDuff, R.E., 1987, Advection of pore waters in the Marianas Mounds hydrothermal region as determined from nutrient profiles [abs.]: Eos, v. 68, p. 1531.

Yamamoto, Koshi, 1987, Geochemical characteristics and depositional environments of cherts and associated rocks in the Franciscan and Shimanto terranes: Sedimentary Geology, v. 52, p. 65-108.

Yeh, H-W., Hein, J.R., and Koski, R.A., 1985, Stable isotope study of volcanogenic- and sedimentary-manganese deposits: U.S. Geological Survey Open-File Report 85-662, 20 p. 


\section{SELECTED SERIES OF U.S. GEOLOGICAL SURVEY PUBLICATIONS}

\section{Perlodicals}

Earthquakes \& Volcanoes (issued bimonthly).

Preliminary Determination of Epicenters (issued monthly).

\section{Technical Books and Reports}

Professional Papers are mainly comprehensive scientific reports of wide and lasting interest and importance to professional scientists and engineers. Included are reports on the results of resource studies and of topographic, hydrologic, and geologic investigations. They also include collections of related papers addressing different aspects of a single scientific topic.

Bulletins contain significant data and interpretations that are of lasting scientific interest but are generally more limited in scope or geographic coverage than Professional Papers. They include the results of resource studies and of geologic and topographic investigations; as well as collections of short papers related to a specific topic.

Water-Supply Papers are comprehensive reports that present significant interpretive results of hydrologic investigations of wide interest to professional geologists, hydrologists, and engineers. The series covers investigations in all phases of hydrology, including hydrogeology, availability of water, quality of water, and use of water.

Circulars present administrative information or important scientific information of wide popular interest in a format designed for distribution at no cost to the public. Information is usually of short-term interest.

Water-Resources Investigations Reports are papers of an interpretive nature made available to the public outside the formal USGS publications series. Copies are reproduced on request unlike formal USGS publications, and they are also available for public inspection at depositories indicated in USGS catalogs.

Open-File Reports include unpublished manuscript reports, maps, and other material that are made available for public consultation at depositories. They are a nonpermanent form of publication that may be cited in other publications as sources of information.

\section{Maps}

Geologic Quadrangle Maps are multicolor geologic maps on topographic bases in $71 / 2$ - or 15-minute quadrangle formats (scales mainly $1: 24,000$ or $1: 62,500$ ) showing bedrock, surficial, or engineering geology. Maps generally include brief texts; some maps include structure and columnar sections only.

Geophysical Investigations Maps are on topographic or planimetric bases at various scales; they show results of surveys using geophysical techniques, such as gravity, magnetic, seismic, or radioactivity, which reflect subsurface structures that are of economic or geologic significance. Many maps include correlations with the geology.

Miscellaneous Investigations Series Maps are on planimetric or topographic bases of regular and irregular areas at various scales; they present a wide variety of format and subject matter. The series also includes 7 1/2-minute quadrangle photogeologic maps on planimetric bases which show geology as interpreted from aerial photographs. Series also includes maps of Mars and the Moon.
Coal Investigations Maps are geologic maps on topographic or planimetric bases at various scales showing bedrock or surficial geology, stratigraphy, and structural relations in certain coal-resource areas.

Oil and Gas Investigations Charts show stratigraphic information for certain oil and gas fields and other areas having petroleum potential.

Miscellaneous Field Studies Maps are multicolor or black-andwhite maps on topographic or planimetric bases on quadrangle or irregular areas at various scales. Pre-1971 maps show bedrock geology in relation to specific mining or mineral-deposit problems; post-1971 maps are primarily black-and-white maps on various subjects such as environmental studies or wildemess mineral investigations.

Hydrologic Investigations Atlases are multicolored or black-andwhite maps on topographic or planimetric bases presenting a wide range of geohydrologic data of both regular and irregular areas; principal scale is $1: 24,000$, and regional studies are at $1: 250,000$ scale or smaller.

\section{Catalogs}

Permanent catalogs, as well as some others, giving comprehensive listings of U.S. Geological Survey publications are available under the conditions indicated below from the U.S. Geological Survey, Books and Open-File Reports Section, Federal Center, Box 25425, Denver, CO 80225. (See latest Price and Availability List.)

"Publications of the Geological Survey, 1879-1961" may be purchased by mail and over the counter in paperback book form and as a set of microfiche.

"Publications of the Geological Survey, 1962- 1970" may be purchased by mail and over the counter in paperback book form and as a set of microfiche.

"Publications of the U.S. Geological Survey, 1971-1981" may be purchased by mail and over the counter in paperback book form (two volumes, publications listing and index) and as a set of microfiche.

Supplements for 1982, 1983, 1984, 1985, 1986, and for subsequent years since the last permanent catalog may be purchased by mail and over the counter in paperback book form.

State catalogs, "List of U.S. Geological Survey Geologic and Water-Supply Reports and Maps For (State)," may be purchased by mail and over the counter in paperback booklet form only.

"Price and Availability List of U.S. Geological Survey Publications," issued annually, is available free of charge in paperback booklet form only.

Selected coples of a monthly catalog "New Publications of the U.S. Geological Survey" available free of charge by mail or may be obtained over the counter in paperback booklet form only. Those wishing a free subscription to the monthly catalog "New Publications of the U.S. Geological Survey" should write to the U.S. Geological Survey, 582 National Center, Reston, VA 22092.

Note.--Prices of Government publications listed in older catalogs, announcements, and publications may be incorrect. Therefore, the prices charged may differ from the prices in catalogs, announcements, and publications. 


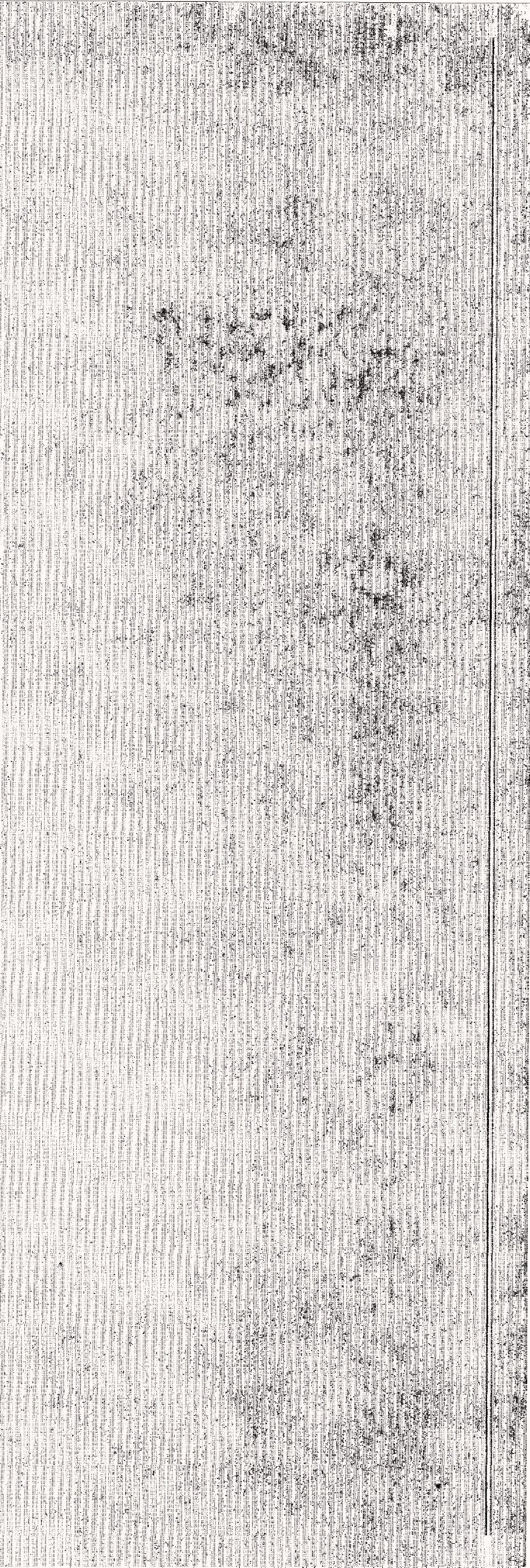

